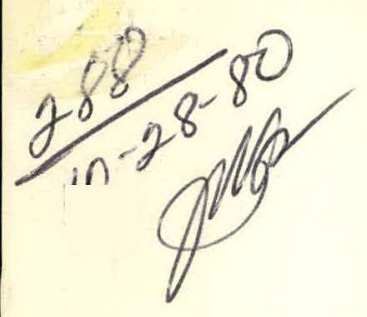

\title{
Analysis of the Need for Intermediate and Peaking Technologies in the Year 2000
}

April 1980

Prepared for:

U.S. Department of Energy

Assistant Secretary for Resource Applications

Division of Electrical Systems

Under Contract No. AC02-79ET29999 


\section{DISCLAIMER}

This report was prepared as an account of work sponsored by an agency of the United States Government. Neither the United States Government nor any agency Thereof, nor any of their employees, makes any warranty, express or implied, or assumes any legal liability or responsibility for the accuracy, completeness, or usefulness of any information, apparatus, product, or process disclosed, or represents that its use would not infringe privately owned rights. Reference herein to any specific commercial product, process, or service by trade name, trademark, manufacturer, or otherwise does not necessarily constitute or imply its endorsement, recommendation, or favoring by the United States Government or any agency thereof. The views and opinions of authors expressed herein do not necessarily state or reflect those of the United States Government or any agency thereof. 


\section{DISCLAIMER}

Portions of this document may be illegible in electronic image products. Images are produced from the best available original document. 


\section{NOTICE}

This report was prepared as an account of work sponsored by the United States Government. Neither the United States nor the United States Department of Energy, nor any of their employees, makes any warranty, express or implied, of essumies any leyal liability or responsibility for the accuracy, completeness, or usefulness of any information, apparatus, product, or process disclosed, or represents that its use would not infringe privately owned rights. Reference herein to any specific commercial product, process, or service by trade name, mark, manufacturer, or otherwise, does not necessarily constitute or imply its endorsement, recommendation, or fevoring by the United States Government or any agency thereof. The views and opinions of authors expressed herein do not necessarily state or reflect those of the United States Government or any agency thereof.

Ava1lable from:

Natlonal Iechnical Information Service (NTIS)

D.S. Department of Commerce

5285 Port Royal Road

Springfield, Virginia 22161

Price: Printed copy: $\$ 15.00$

Microfiche: $\$ 4.00$ 


\section{Analysis of the Need for Intermediate and Peaking Technologies in the Year 2000}

April 1980

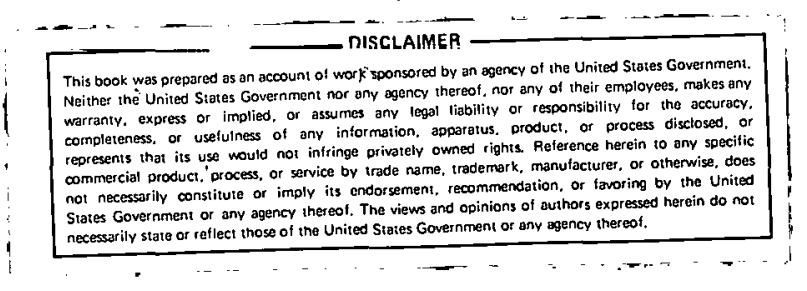

Prepared for:

U.S. Department of Energy

Assistant Secretary for Resource Applications

Division of Electrical Systems

Washington, D.C. 20461

Prepared by:

Stephen M. Barrager \& Gregory L. Campbell

Decision Focus Incorporated

Palo Alto, California 94304

Under Contract No. AC02-79ET29999 


\section{CONTENTS}

Section

Page

EXECUTIVE SUMMARY

Approach ii

Insights $\quad \therefore \quad 111$

Conclusions - iv

1 INTRODUCTION

Causes of Demand váriation " 1-5

Load Growth Issues 1-10

Objectives 1-13

Approach i $1-14$

Report Out1ine 1-15

2. ELECTRIC LOAD ANALYSIS MODELS 2-1

Model Data Structure 2-2

Demand Submodel 2 2-9

Capacity Expansion and Operation Submodel 2-17

Load Management Submodel 2-17

Operation of the Load Management Model $\quad 2-22$

Interruptible Service Submodel 2-29

Conclusion $2-30$

3 LOAD SHAPE ANALYSIS 3-1

Base Cases 3-1

Sensitivity Analysis . 3-7

Analysis of Load Management 3-16

Summary $3-26$

4. ASSESSMENT OF THE NEED FOR PEAKING AND INTERMEDIATE TECHNOLOGIES 4-1 IN THE YEAR 2000

Annual Load Duration Curve Results 4-2

System Optimization Results $\quad$ 4-2

Maximum. Utilization of Energy Storage 4-10

5 REFERENCES $5-1$ 
CONTENTS (continued)

Appendix

A FORMULATION OF THE DEMAND MODEL

B FORMULATION OF THE LOAD MANAGEMENT MODEL

C ELECTRIC CAPACITY EXPANSION AND OPERATION MODEL

D DEMAND MODEL DATA AND DEFINITIONS OF END-USE TECHNOLOGIES

E END-USE LOAD SHAPES

F OUTPUTS OF SENSITIVITY ANALYSIS RUNS

G OUTPUTS OF LOAD -MANAGEMENT ANALYSIS RUNS
Page

$A-1$

B-1

C-1

D-1

E-1

F-1

G-1 


\section{ILLUSTRATIONS}

$\underline{\text { Figure }}$

$\underline{\text { Page }}$

1-1 Illustrative Hourly Load Profile for an Entire Year . 1-2

1-2 Sample Annual Load Duration Curve $1-3$

1-3 Dafly Load Shapes for Five Representative Weekdays : * 1-7 (North Central Region, 1980)

1-4 Cross-Section of Peak Summer Day in North Central Region, 1980 1-8

1-5 Cross-Section of Peak Winter Day in .North Central Region, 1980 1-9

1-6 Comparison of Summer Weekdays and Weekend Days (1980, North 1-11 Central Region)

2-1 Model Overview 2-3

2-2 Components of Demand Mode1 " . . . 2-10

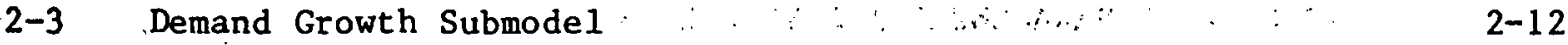

2-4 Energy Allocation Submodel: Division of Energy by Season, 2-14 Weekday, and Weather

2-5 Schematic of Load Shape Construction Submodel 2-16

2-6 Schematic of Capacity Expansion and Operation Submode1 2-18

2-7 System Load Before and After Application of the Load 2-21

Management Algorithm (Commercial Air Conditioning Example)

2-8 Components of Load Management Model 2-23

2-9 Alternate Modes of Operation of the Load Management Mode1 2-24

2-10 Illustration of the Solution Procedure for the Load 2-26 Management Mode1

2-11 Simplified Power Costing Model 2-27

2-12 System Load Before and After Application of Interruptible 2-28 Service Submodel

3-1 Results of Load Management Case 1, North Central Region, 3-21 Year 2000

3-2 Results of Load Management Case 5, North Central Region, 3-23 Year 2000

3-3 Annual Load Duration Curves for Base Case and Load Management 3-24 Case 5 (North Central Region)

3-4 Hourly Time-of-Use Prices Corresponding to Load Management 3-25 Case 5, North Central Region, Year 2000 
TABLES

$\underline{\text { Table }}$

Page

1-1 1979 Load Factors and Peak Ratios for Nine NERC Regions $1-4$

1-2 Major Causes of Recurring Electricity Demand Patterns

2-1 End-Use Categories

2-2 Technologies by End Use

2-3 Day Type Categories.

3-1 Summary of Base Case Data, North Central Region

3-2 Summary of Base Case Data, South Central Région

3-3 Comparison of North Central Base Cases 3-6

3-4 Comparison of South Central Base Cases 3-6

3-5 Sensitivity Analysis Results, North Central Region. 3-9

3-6 Sensitivity Analysis Results, South Central Region 3-10

3-7 Load Management Analysis Results, North Central Region 3-17

3-8 Load Management Analysis Results, South Central Region 3-18

4-1 Results of Capacity Factor Analysis North Central Region. 4-3

4-2 Results of Capacity Factor Analysis South Central Region 4-4

4-3 Thermal Generation Assumptions (Base Case) 4-6

4-4 Financial Assumptions 4-7

4-5 Results of Capacity Optimization North Central Region 4-8

4-6 Results of Capacity Optimization South Central Region 4-9 
This analysis was conducted to assess the impact of load management on the future need for intermediate and peak generating technologies (IPTs) such as combustion turbines, pumped storage, and cycling coal plants. There would be a reduced need for IPTs if load management activities such as time-of-use pricing, together with customer-owned energy storage devices, hot water heater controls, and ințerruptible service, can economicaliy remove most of the variation from electric power demands. The objective of this analysis is to assess the need for IPTs in an uncertain future, which will probably include load management and time differentiated electricity prices.

The analysis is exploratory in nature and broad in scope. It does not attempt to predict the future or to model precisely the technical characteristics or economic desirability of load management. Rather, its purpose is to provide research and development planners with some basic insights into the order of magnitude of possible hourly demand shifts on a regional basis and to determine the impact of load management on daily and seasonal variations in electricity demand.

The system-level impact of any load management activity depends on how it affects each end use. For example, residential hot water heater controls can shift residential water heating demand from early morning to midday or from early evening to midnight. The net effect of these shifts on a utility system's total demand depends on how many customers have the controls and how much electricity each of them uses to heat water. If the total electric energy used to heat water is a small fraction of total demand, the impact of controls will be small even if they are used by all customers. 


\section{APPROACH}

The load management analysis was done with a load shape forecasting method originally developed by Decision Focus Incorporated (DFI) for the Electric Power Research Institute (EPRI).* The method constructs dally load shapes from end-use electricity demands, accounting for the contribution of each end use to the total daily load shape for a set of days representing different seasons, extremes of hot and cold weather, and days of the week. The method accounts for the following factors:

1. Energy demand growth or decline by end use (percentage per year).

2. Implementation of load management or market penetration of new technologies (percentage of new demand or percentage of replacement units).

3. Seasonal variation in demand by end use. This is particularly important in describing heating and cooling demands.

4. Daily temperature varlations within seasons. These variations are the main determinant of the relative magnitude of demand during peak - and normal-demand days.

Differences in climate and appliance saturations (e.g., air conditioning) can have significant impacts on demand patterns. The analysis presented here considers demands in two regions corresponding to the North Central and South Central United States.** In general, climatic conditions in the North Central Region are representative of most northern-tier states; and, likewise, the South Central Region is representative of the southern tier. Such generalizations do not apply to the West and Mid-Atlantic regions.

The first step in this analysis was to review data sources and develop a base case, no-load-management, projection of electric demand patterns in

*Integrated Analysis of Load Shapes and Energy Storage, March 197.9, EPRI EA-970.

**The North Central Region includes the East and West North Central census regions. The South Central Region includes the East and West South Central and South Atlantic census regions. 
the year 2000. A series of sensitivity analyses were then performed to determine the relative importance of model assumptions, appliance saturations, energy allocations, and growth rates. The impact of new technologies on regional electric demands was also assessed; these technologies included solar space heat and the electric car.

New models were developed to simulate the response of end-use demands to time-of-use pricing. The load management actions simulated include

1. Installation and operation of space heat and air-conditioning systems incorporating energy storage.

2. Hot water heater control.

3. Changes in hourly electricity. consumption patterns.

4. Change in total electric energy consumption.

5. Interruptible service.

An electricity-cost-minimization model was used to examine the role of IPTs in the year 2000 with and without load management. The cost minimizations were based on long-range cost projections for coal and oil (fluid fuels).

\section{INSIGHTS}

- A large fraction of annual demand varfation is due to seasonal and weekly demand cycles.

- Most load management will reduce only daily (diurnal) demand fluctuations.

- Seasonal variations can be reduced somewhat by the proper use of energy storage on space conditioning loads and dual-fuel (bivalent) space heating.

- Future load shapes are very sensitive to electric space heat saturations in both the new and retrofit markets.

- The North Central Region will be dominantly winter peaking by 2000 if residential space heat saturations exceed $50 \%$ of new installations and $20 \%$ of replacements.

- The South Central Region remains summer peaking even with the same space heat saturations.

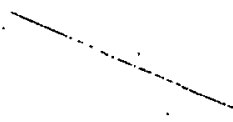


- Energy use data for the commercial sector is weak. How much energy is used for commercial air conditioning? Per unit of floor space? Total by region? Air conditioning saturations?.. Today? In the future? What are replacement rates?

\section{CONCLUSIONS}

- There will be a need for IPTs in the year 2000. The probability is. high that the demand for IPTs will be about the same as today. The required capacity with less than a $15 \%$ capac1ty factor is in the 20-30\%* range under a broad range of growth and load management scenarios.

- The need for IPTs will be greater in the South Central Region because of continued strong summer peaking.

- Annual load factor increases of more than 10 percentage points are unlikely even with 2 high level of load management sucress.

- The greatest load-alterling potential exists in the following end uses:

- industrial load management

- cool storage in summer peaking regions

- space heat storage in winter peaking regions

This conclusion is based on estimates of the amount of demand that can be reallocated among time periods and the beneficial effect of the reallocation.

- As in the past, growth in space conditioning loads will be the single most important determinant of spontaneous changes in electricity demand patterns.

- Without load management, storage could account for 20 to $30 \%$ of installed generating capacity in the year 2000 (assuming a $75 \%$ turnaround efficiency). Load management will probably reduce this potential by fewer than 10 percentage points.

*Percent of installed capacity. 


\section{Section 1}

INTRODUCTION

The residential, commercial, and industrial demand for energy varies hour by hour, day by day, and season by season. The pattern of these varlations reflects fluctuations in heating and cooling demands; lighting requirements; working hours; and a multicude of other physical, social, economic, and religious factors. Suppliers of electric energy are more sensitive to demand variation than are other energy providers because electric energy is relatively more difficult and costly to store.

The general character of electric demand variations is illustrated in Figure 1-1. This is the simulated hourly demand of a northeastern utility over a one-year period. Dally, weekly, and seasonal variations are all apparent in the pattern. This pattern is typical for U.S. utilities, except that seasonal variations are usually more pronounced because of larger or more variable air-conditioning loads.

The simplest representation of the dynamic aspects of electric demand is the annual load duration curve. An example is shown in Figure 1-2. This curve shows the maximum (peak) and minimum demand as well as the number of hours per year that demand exceeds any spectfied level. Load factor refers to the ratio of average demand to maximum demand over a specified time period and is often expressed as a percent. Currently the average annual load factor for the entire United States is about 0.61 [1].

Demand statistics for nine National Electric Reliability Council (NERC) regions of the United States are summarized in Table 1-1. This table shows that most of the United States is summer peaking; that is, the ratio of 


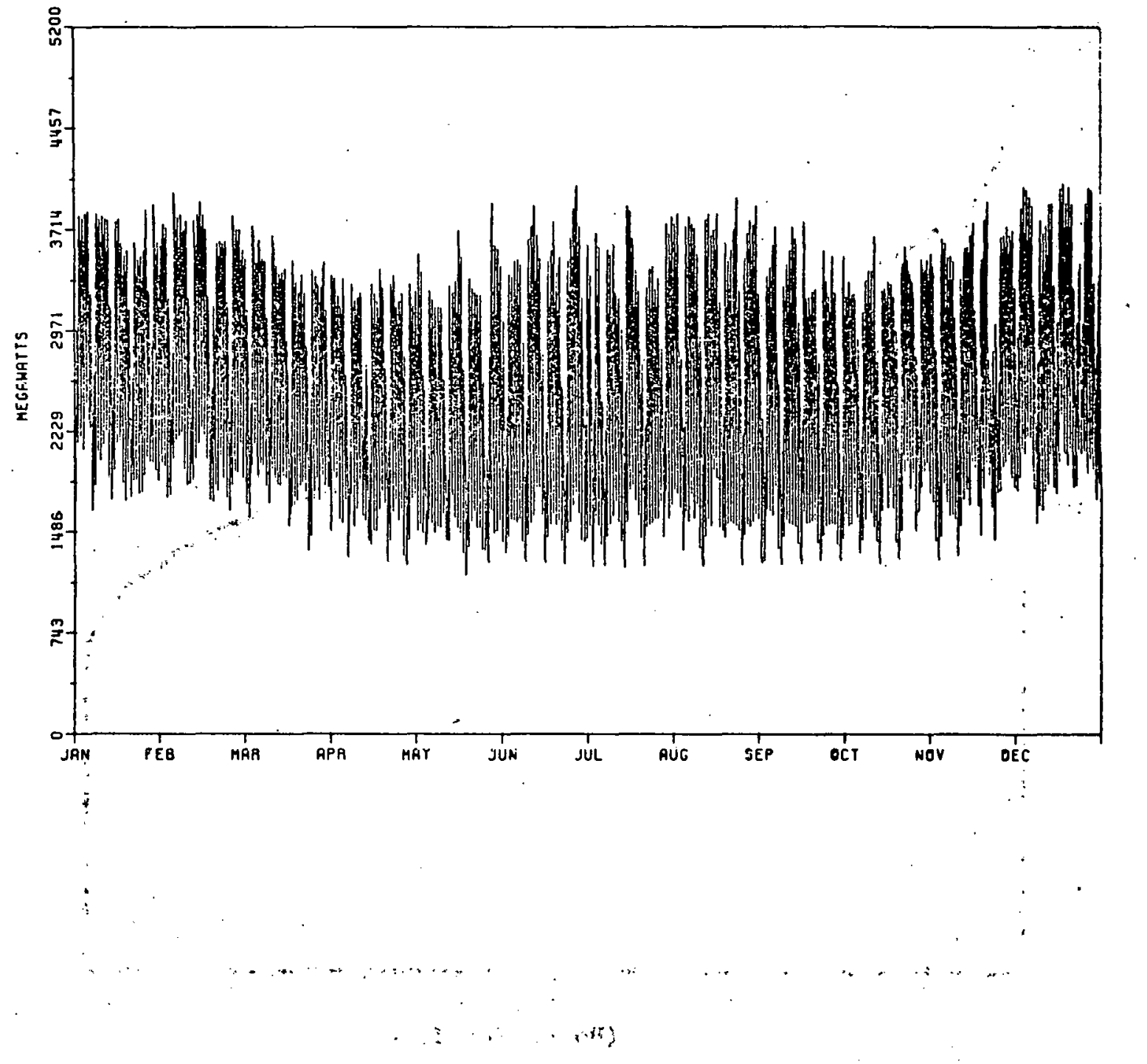

Figure 1-1. Illustrative Hourly Load Profile for an Entire Year Source: Electrical Energy Demand 1979-1980, Northeast Utility System 


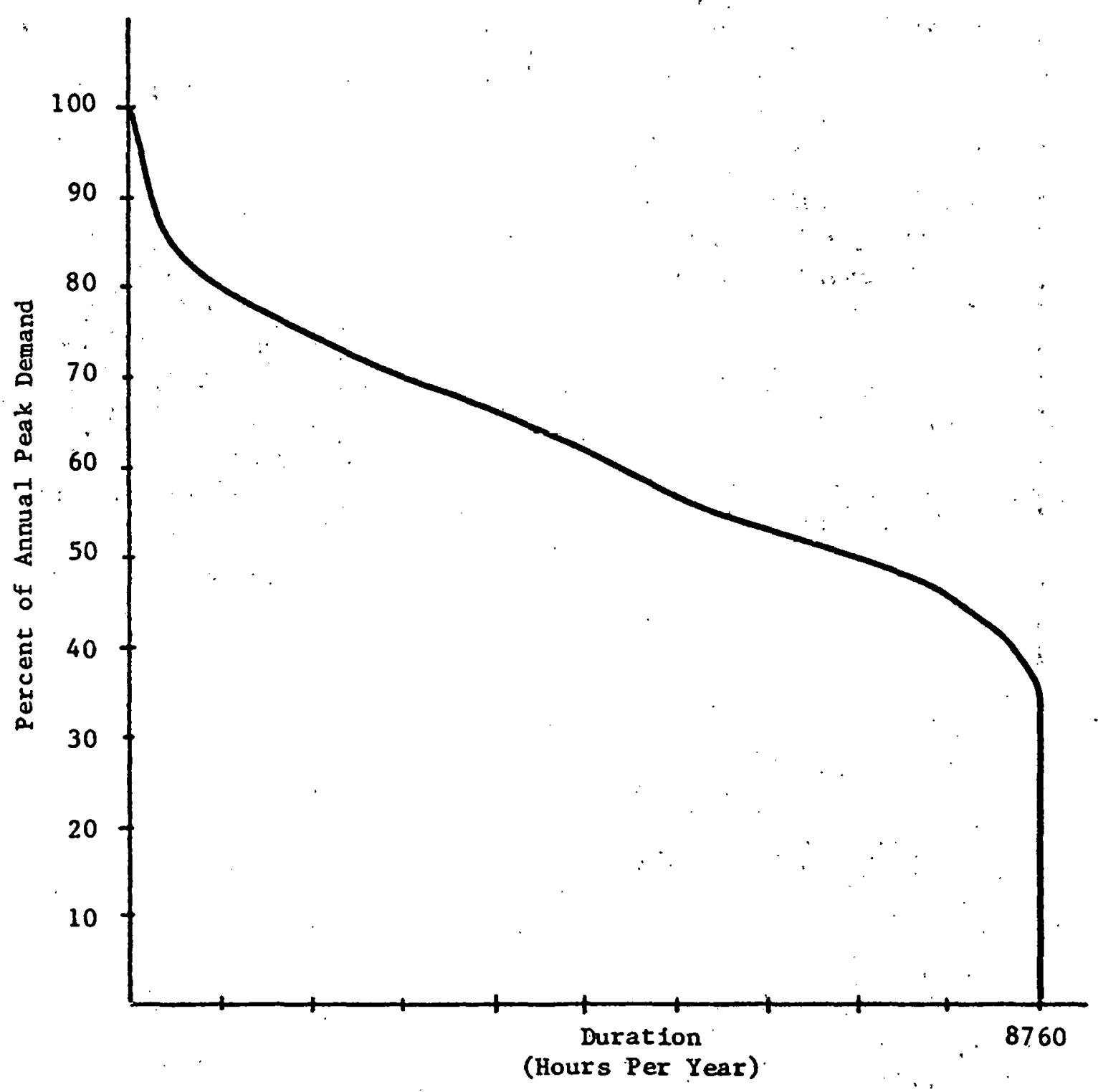

Figure 1-2. Sample Annual Load Duration Curve 
Table 1-1

1979 LOAD FACTORS AND PEAK RATIOS FOR NINE NERC REGIONS

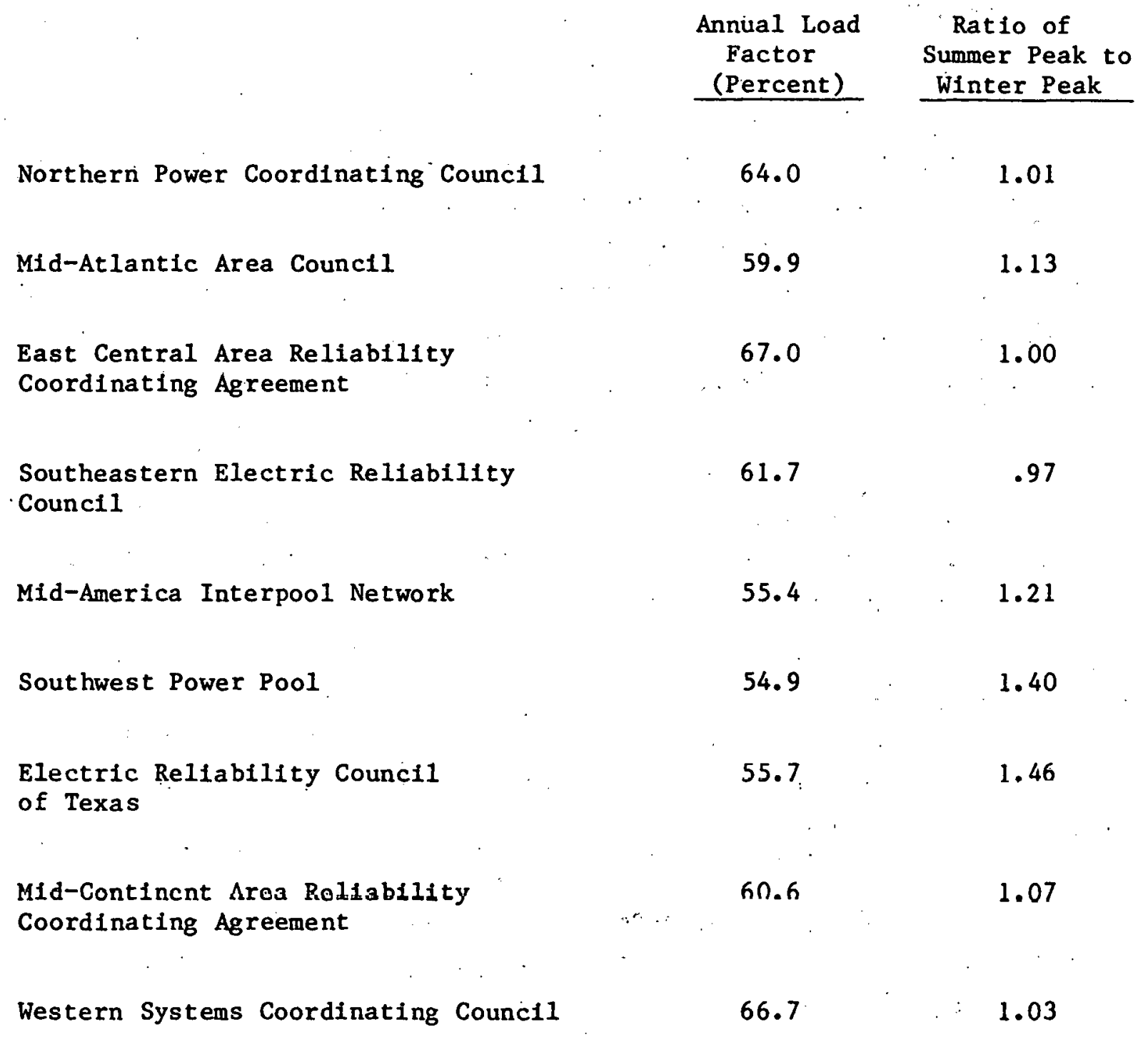

Source: Reference [1] 
summer peak to winter peak demand is greater than one. (The average is 1.08.) The table also shows that annual load factors for the NERC reliability regions ranged from $55 \%$ to $67 \%$ in 1979 .

\section{CAUSES OF DEMAND VARIATION}

To understand how the demand for electricity might change over the next 20 years, it is helpful to review the major determinants of daily, weekly, and seasonal demand cycles (patterns): We have listed some of the causes and results in Table 1-2. At a fundamental level, seasonal and daily variations in demands are caused by movements of the earth relative to the sun. These movements in turn cause periodic cycles in heating and air-conditioning demand. The rotation of the earth also causes 24-hour-long cycles in electric lighting, appliance use, and industrial and commercial activity. Weekly cycles are due mostly to cultural factors. In particular, since Saturday, is traditionally a market day, office and factory demands are reduced while retail store loads remain at weekday levels. Since Sunday is traditionally a day of rest, office, retail store, and Industrial loads are all reduced. Other cultural factors reflected in the demand for electricity include the fact that most people work a 40-hour week (8-hour day) and eat (and therefore prepare) three regular meals each day. To the extent that any of the above factors change, there will be significant changes in the timing of electric energy demands. Most of these patterns will change very slowly, if at all.

The changes in daily load shapes induced by climate and weather are illustrated in Figure 1-3. This figure shows the daily load shape for five representative days: normal weather days in summer, winter, and fall/ spring and extreme weather (peak) days in summer and winter.

The end-use makeup of the peak summer and winter demands is revealed in the cross-sectional breakdown. of system demands shown in Figures $1-4$ and $1-5$. These. figures show how much each of several end uses contributes to 
Seasonal Cycles

Mean Daily Temperature

Day Length

Weekly Cycles

5-Weekday Workweek

Saturday (Market Day)

Sunday (Day of Rest)

\section{Daily Cycles}

Solar Insulatlun

Three Meals (two are light and one is heavy)

9-to-5 Workday

Bedtime (averages somewhere between 9 p.m. and midnight)
Seasonal variation in space heat, air conditioning, water heat, and refrigeration

Timing of lighting demands

Regularity in industrial, school, and other 40-hour/week institutions

Low Industrial and office demands

Low industrial, office, and retail demands

Daytime drop in opace heating loads; peak in cooling loads

Nighttime lighting demands

Three cooking peaks with highest in evening

High industry and commercial loads during workday; peak in residential appliance loads during evening

No lighting and reduced appliance use; space heat demand set back 


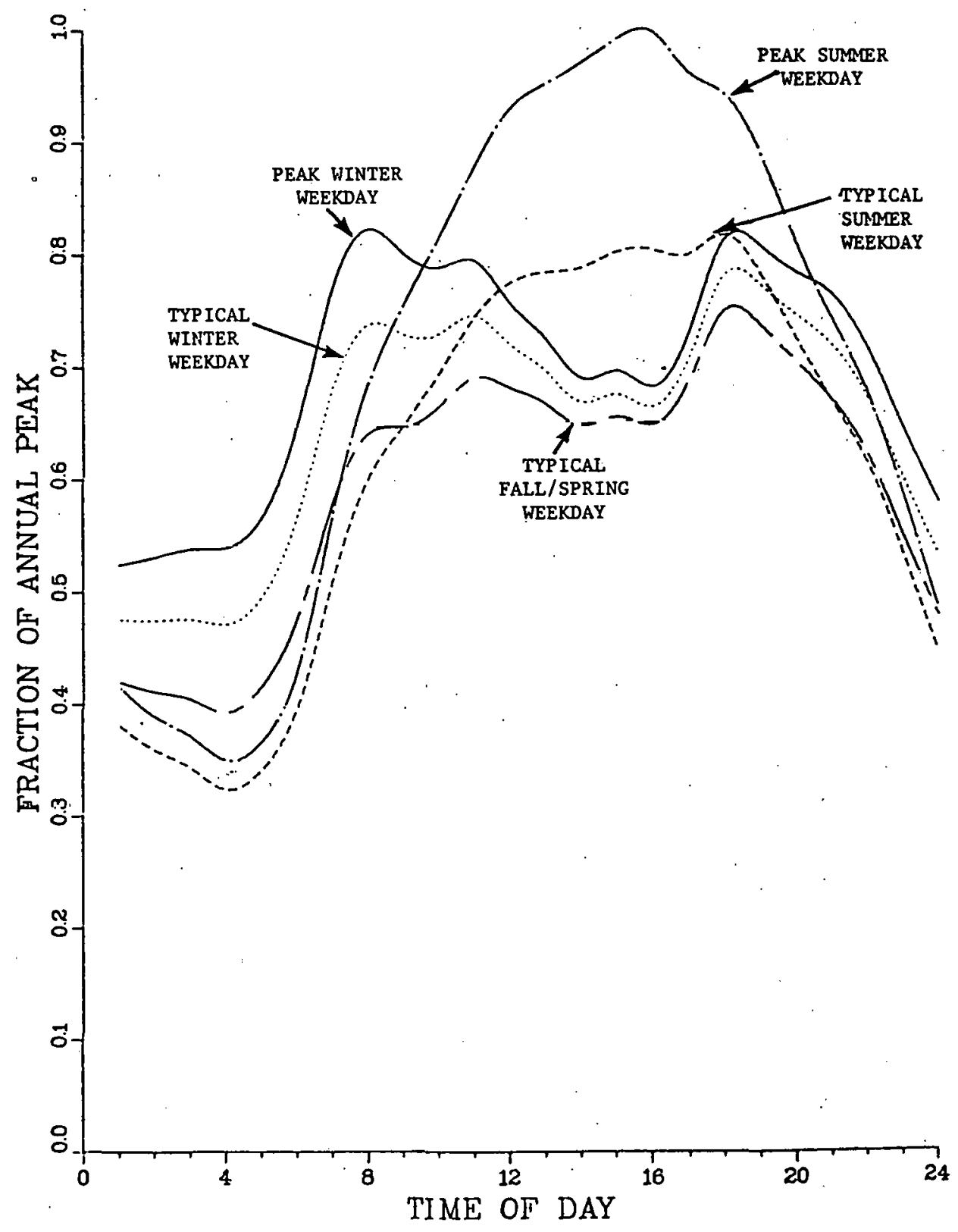

Figure 1-3. Daily Load Shapes for Five Representative Weekdays (North Central Region, 1980). 


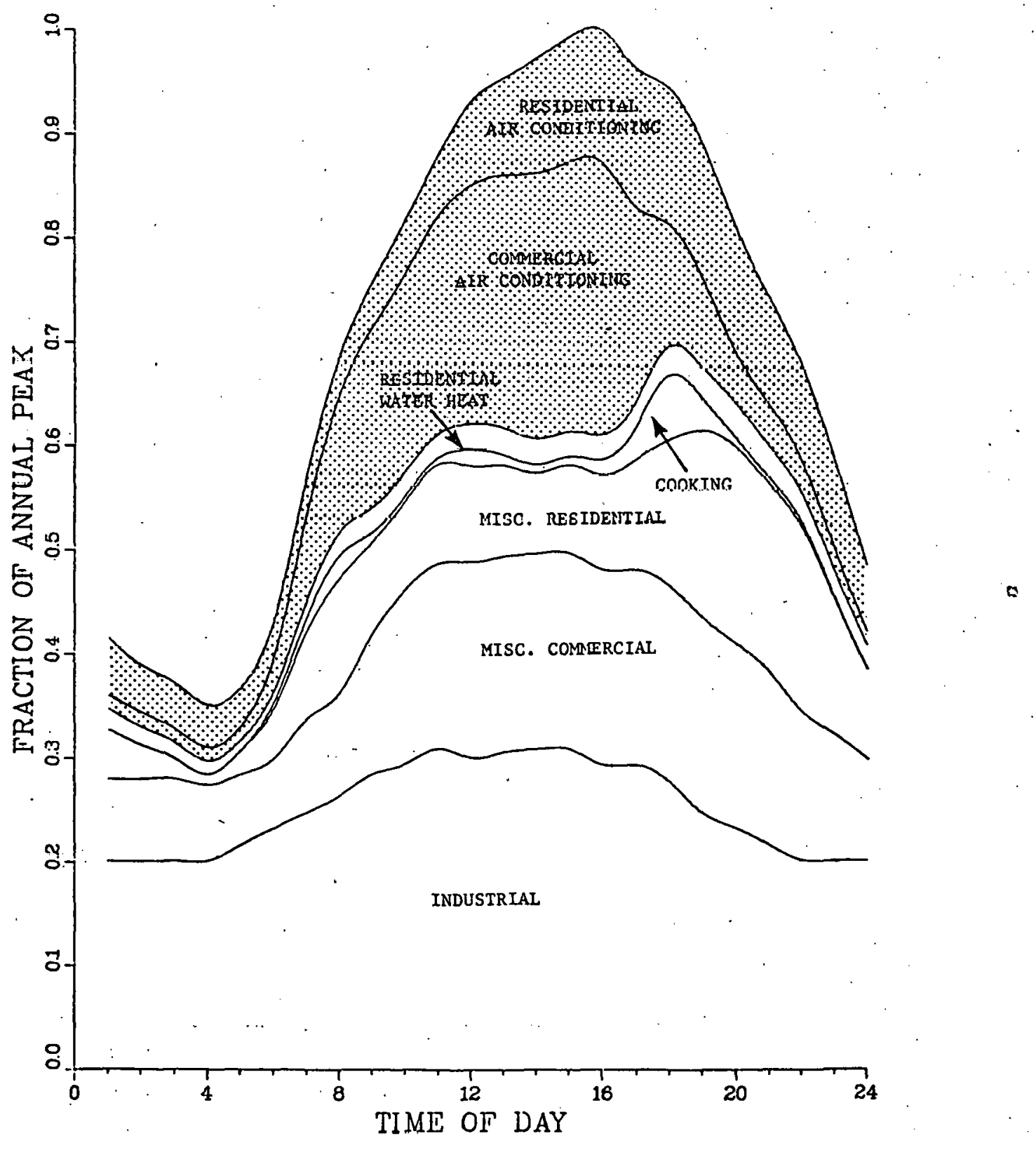

Figure 1-4. Cross-Section of Peak Summer Day in North Central Region, 1980 


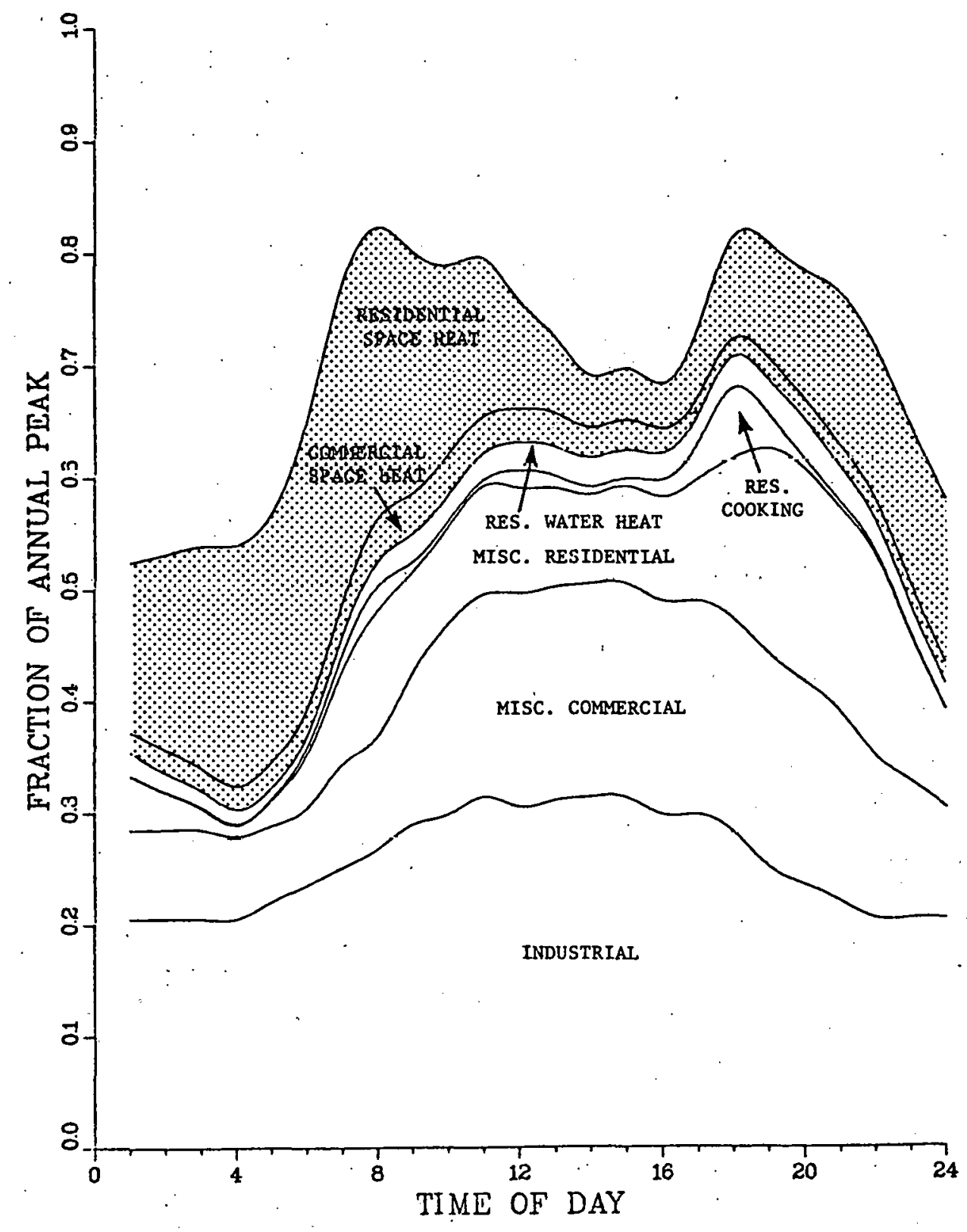

Figure 1-5. Cross-Section of Peak Winter Day in North Central Region, 1980 
the total daily demand. The weather-sensitive portions of these graphs are shaded to reveal their important role in determining overall load shape.

The extent of weekly load variation is illustrated in Figure 1-6. This figure compares normal and peak weekdays with Saturday and Sunday load shapes. Changes in both the magnitude and shape of the load are apparent in the figures. Note that all the figures are the result of simulations using data representative of the North Central United States. They compare very favorably with actual observed loads.

\section{LOAD GRONTH ISSUES}

The shape of future electricity demands is highly uncertain. Several unpredictable factors will probably act simultaneously to produce changes in daily, weekly, and seasonal demand patterns. These changes can be placed in two general categories: those that result from changes in the mixture of end-use demands and those changes induced by time-of-use electricity pricing.

Load growth developments that might cause load shape changes include the following:

1. High growth in commercial sector relative to residential and industrial ( $4 \%$ per year rather than $2 \%$ ). This might be caused by a shift in the labor force into service industries and high growth in personal income relative to population growth and growth in industrial activity.

2. Increasing electric space heat saturations brought about by high oil and gas prices together with increasing deployment of the electric heat pump. Currently, only about $15 \%$ of all residential space heating is electric. Future increases in this fraction could cause residential space heat to become a major determinant of seasonal and daily peaking patterns.

3. Increasing residential air conditioning saturations. Currently, about $35 \%$ of residences in the northern United States have a1r conditioning, and most of these units are room rather than central. The trend is toward higher air-conditioning penetrations, mostly of the central type, which has a significantly different daily demand profile from room-sized units (see Figure E-2). 


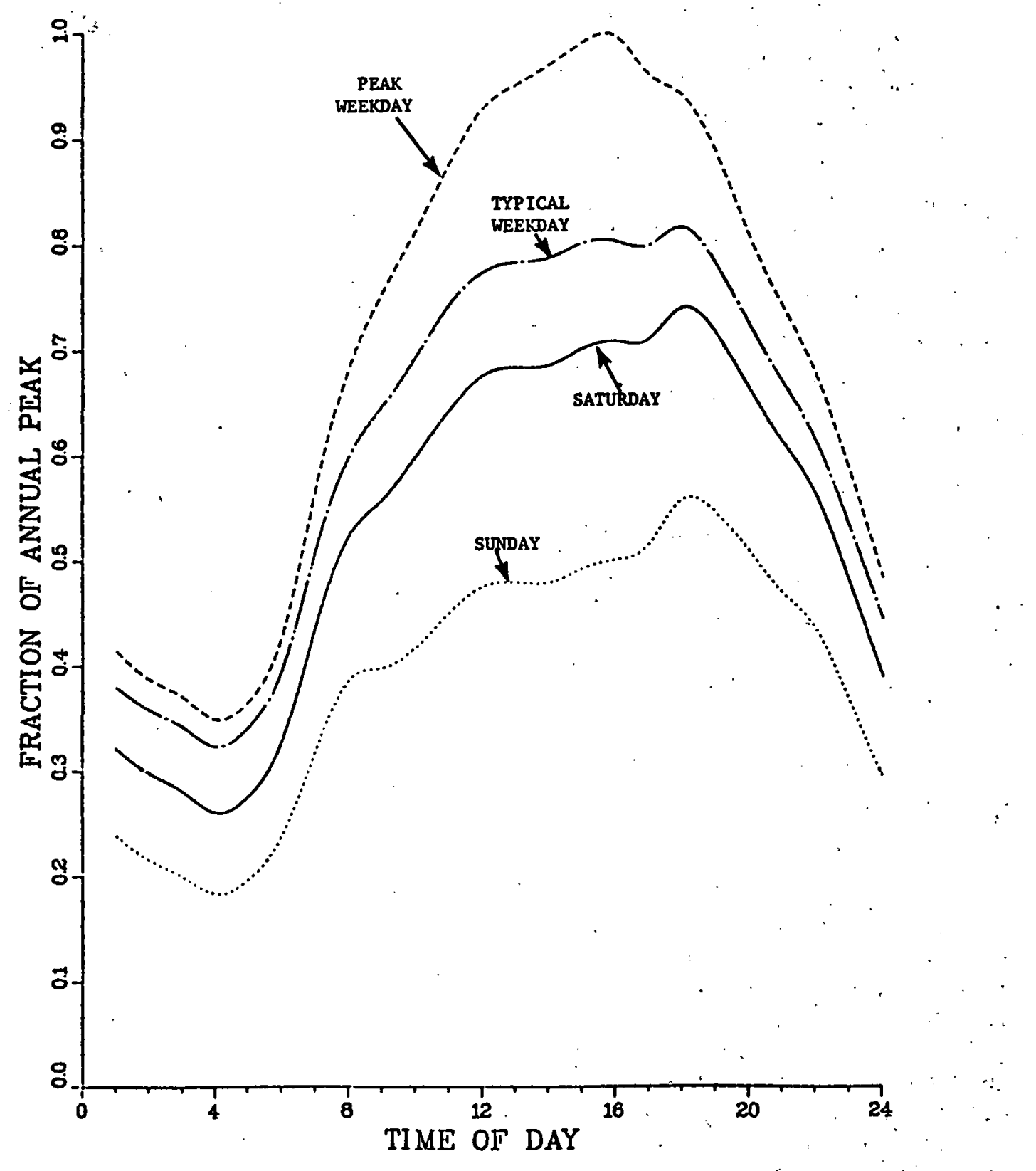

Figure 1-6. Comparison of Summer Weekdays and Weekend Days (1980, North Central Region). 
4. Increasing appliance efficiencies and improvements in building insulation. These developments will slow growth in selective end uses and cause undetermined changes in the response of loads to weather variations.

5. Increasing deployment of electric vehicles. The magnitude and characteristics of electric vehicle demands on central station power generation is unknown.

6. Increasing use of solar space heating. Electric energy will be used in conjunction with solar heating in two ways. First, it will be used to pump fluids through heat collection and storage systems. Second, it will be used as backup for solar systems, . providing heat during extended cold or cloudy weather.

7. Increasing cogeneration or self-generation by industry.

The changes brought about by time-of-use pricing (i.e., prices that reflect: hourly changes in supply costs) will depend on the extent to which customers are able and willing to change their consumption in response to new price'structures. Price changes will mean more expensive energy (e.g.' commercial air conditioning) for users with demands concentrated in peak : hours. For others, such as the farmer who pumps irrigation water early in the morning, the total cost might drop. Total consumption and hourly demand shifts will change accordingly on a use-by-use, customer-by-customer basis.

Time-of-use pricing might induce residential and commercial customers to Install a broad range of energy storage devices to take advantage of low off-peak prices. Of particular interest are heat storage units, now widely used in Europe, and storage units being developed for use in conjunction with residential and commercial air conditioning.

Other load management developments that could have substantial demand impacts are hot water heater controls, dual-fuel or bivalent* space heat (with and without storage), and interruptible service.

*The terms dual-fuel and bivalent are used to describe space heating systems that use electricity backed up by gas or oil. The gas or oil backup is used only during extreme cold. A major advantage of this type of system is the removal of significant variation in the electric demand. 
Future. changes in electric energy demand patterns will differ among. geographic regions. The demand differences result from differences in climate, industrial makeup, growth rates, and appliance saturations. The important differences are in the role of the weather-sensitive loads, specifically air conditioning and space heat.

It is apparent from the demand pattern in Figure $1-1$ and from the load duration curve (Figure 1-2) that utility systems require some generation capacity that is suited for operating for only a small fraction of each year and is capable of being cycled up and down through a wide output range, or of being turned on and of on a daily basis. The technologies used for these purposes are generally called peaking and intermediate. Historically, the generation units used for this purpose have been those with relatively low capital costs and high operating costs, such as oil-fired combustion turbines and steam boilers. Pumped and ponded hydro facilities are also commonly used.

The future need for peaking and intermediate capacity will depend on the character of future demands. The need will certainly be diminished by time-of-day pricing and the deployment of such load management technologies as customer storage. These developments will tend to reduce demand variations. But will the decrease be significant in view of the fact that much of the demand for peaking capacity is caused by seasonal and weekly demand fluctuations?

\section{OBJECTIVES}

The objective of this analysis is to provide research and development. planners with a sense of the magnitude of possible hourly demand shifts on. a regional basis. We are not attempting to predict the future or model precisely the technical characteristics or economic desirability of load management devices. 
It is the cumulative result of many changes that will ultimately determine the hourly pattern of electric demands. Therefore, in pursuing our objectives we have tried to include all the issues at some level of detail rather than focus on a limited subset of load developments or customer classes.

\section{AP PROACH}

This analysis used a load pattern forecasting methodology recently developed for R\&D planners at the Electric Power Research Institute [2]. The method constructs dally load shapes from end-use electricity demands, accounting for the contribution of each end use to the total daily load shape for a set of days representing different seasons and extremes of hot and cold weather. The method accounts for the following factors:

1. Energy demand growth or decline by end use (percentage per year). For example, residential space heat demand may increase at $2 \%$ per year in response to housing construction, conservation, changes in new housing characteristics, and housing retirements. The total energy served by a particular technology, such as electric heat pumps, is equal to an initial market share (minus retirements) plus growth due to a share of new heating installations and replacements.

2. Implementation of load management or market penetration of new technologies (percentage of new demand or percentage of replacement units).

3. Seasonal variation in demand by end use. This is particularly important in describing heating and cooling demands.

4. Daily temperature vartation within seasons. These variations are the main determinant of the relative magnitude of demand during peak- and normal-demand days.

The system-level impact of any load management activity depends on how it affects each end use. For example, residential hot water heater controls can shift residential water heating demand from early morning to midday or from early evening to midnight. The net effect of these shifts on a utility system's total demand depends on how many customers have the controls and how much electricity each of them uses to heat water. If the 
total electric energy used to heat water is a small fraction of total demand, the impact of controls will be small even if they are used by all customers.

Differences in climate and appliance saturations (e.g., air conditioning) can have significant impacts on demand patterns. The analysis presented here considers demands in two regions that correspond to the North Central and South Central United States.* In general, climatic conditions in the North Central Region are representative of most northern-tier states; likewise, the South Central Region is representative of the southern tier. Such generalizations do not apply to the West.

Data used in this analysis are the best avallable from convenient sources. No new data on energy use or electricity demand patterns were collected or processed. Data from many sources were combined and, in our opinion, appropriately applied. Sensitivity analysis was used to assess the importance of uncertainties in key. parameters, such as energy consumption for commercial air conditioning.

Models were tested or verified by comparing results with actual utility demands for recent years. The agreement in load shapes and seasonal peaking patterns is surprisingly good. Obviously, there is no way to determine whether future demand patterns estimated are accurate; we can say only that they are logically consistent given our model.

\section{REPORT OUTLINE .}

The remainder of this report is organized as follows: Section 2 provides a condensed description of the models used in the analysis. (Details and

*The North Central Region includes the East and West North Central census regions. The South Central Region includes the East and West South Central census regions. 
data sets are contained in the appendixes.) Results of sensitivities on growth rates, model parameters, and appliance saturations are discussed in Section 3, which also contains the analysis of the potential impacts of customer energy storage, appliance control, and time-of-use pricing. The future need for intermediate and peaking technologies is analyzed in Section 4. 


\section{Section 2}

ELECTRIC LOAD ANALYSIS MODELS

This section presents an overview of the models developed to estimate the future need for intermediate and peaking technologies. The structure and interconnections of the basic model components are described in sufficient detail for an understanding of how the models work. The precise mathematical relations are contained in the appendixes.

The model has three basic components: a demand submodel, a load management submodel, and a capacity expansion and costing submodel. These submodels are linked to simulate a range of possible future outcomes that depend on specific growth parameters and the effectiveness of load management efforts. The ultimate outputs of the model are estimates of the daily demand pattern for representative days and the fraction of total installed generating capacity that is intermediate or peaking rather than baseload.

In reviewing these models, the reader should keep in mind that the scope of the analysis is broad. The objective is not to ascertain precisely the Impacts of any single type of equipment or load management program. Rather, it is to provide a rough comparison of the potential impacts of many alternatives. Therefore, of necessity, the models are simple yet address most of the critical issues, including the use of customer-owned and utility-owned storage and the effects of time-of-use pricing.

The three submodels have several important features:

- The demand submodel is based on a disaggregation of electricity demands by end use. Each end use is further disaggregated by competing equipment technologies, each of which is capable of satisfying the end-use requirement. Thus, differences in end-use growth rates and market shares of technologies are reflected in system load shapes. 
- The load management submodel has a customer-owned storage component as well as a time-of-use pricing response model, permitting study comparisons between widely different load management strategies.

- The capacity expansion and costing submodel uses a linear programming algorithm to determine the installed capacity mix and system operation that minimizes costs. The model includes conventional power generation technologies as well as utility-owned storage.

The interconnections of the three models are shown schematically in Figure 2-1. The demand submodel takes exogenous 1nputs, such as growth rates, appliance installation shares, and technology-specitic load shapes, and produces hourly system load shapes by season and by day type within season. The system load shapes are fed to the capacity expansion and costing submodel, which calculates the optimal utility generation and storage mix.

If the load management submodel is active, it interacts with the demand submodel to modify load shapes in response to time-of-use prices. The prices in turn are generated by a simplified power costing submodel, which approximates marginal costs of production by time period. An iterative method then solves the system to find the set of prices that equal marginal costs.

The components of these three submodels are explained in more detall in the following subsections. First, however, the overall data structure that applies to each of the submodels 18 described.

MODEL DATA STRUCTURE

The organization of the model data is fundamental to the operation of the load analysis models. The data are organized in four dimensions: 


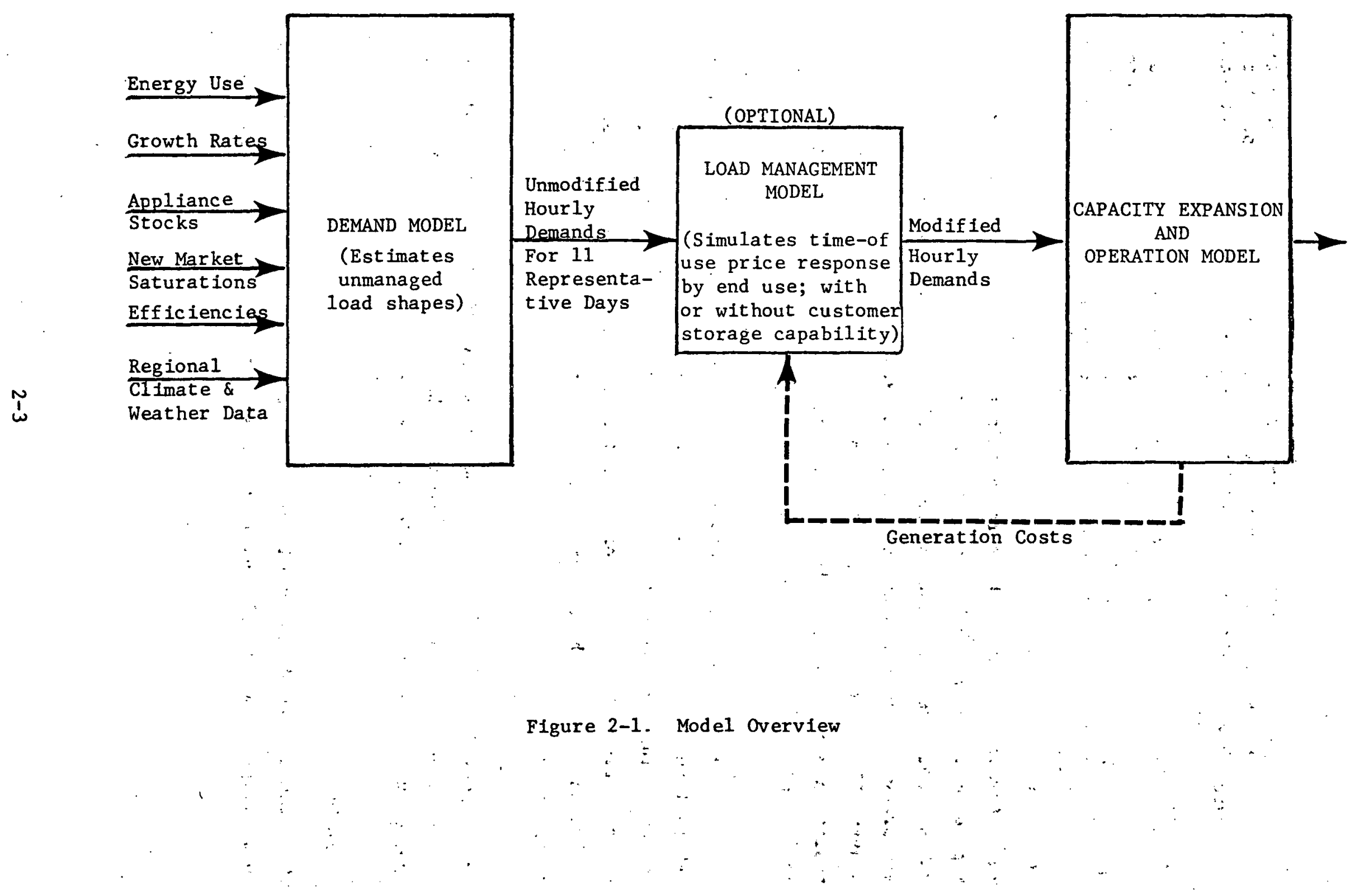


1. end use

2. technology used to satisfy end use

3. day type

4. hour of the day

The ten end-use categorles used in the model are listed in Table 2-1. They are organized first by the four major sectors of the economy, then by divisions within sectors. These categories were chosen to include end uses that are sensitive to weather and that either have potentially high growth rates or may be subject to changes by load management programs.

Each end use represents a service that requires energy but that could be satisfied by alternative technologies, which in turn may use different fuels. For example, residential space heat is a generic quantity measured in Btus of room heat. However, this heat could be provided by several alternatives, including a gas or oll furnace, an electric furnace, an electric heat pump, or a solar heating system. For the purposes of electric load analysis, each technology is characterized by the amount and time distribution of the electricity it uses. Obviously, some technologies, such as an electric furnace, are totally electric, while others may be totally nonelectric. Some, however, are mixed. For example, gas and oil furnaces usually have electric fans, which consume electricity, in addition to the primary fuel of the furnace. Simllarly, solar systems have electric pumps and require a backup system, which is often electric. A complete list of technologies by end use is given in Table 2-2. Appendix D of this report describes simple models that define each technology.

A third model dimension is day type. In the model, the 365 days of the year are divided into eleven categories, as shown in Table 2-3. These categories are defined by season, day of the week, and weather sensitivity. The seasons are defined according to conventions established in Reference [3] : 
Table 2-1

\section{END-USE CATEGORIES}

Residential

Space Heat Water Heat

Air Conditioning Cooking

Other

Commercial

Space Heat

Air Conditioning.

Other

Industrial

Transportation (Automobile) 
Table 2-2

TECHNOLOGIES BY END USE

End Use

1. Residential Space Heat

2. Residential Water Heat

3. Residential Air Conditioning

4. Residential Cooking
Technology

1. No Appliance
2. Gas/Oil Furnace
3. Electric Resistance
4. Electric Heat Pump
5. Solar (Electric Resistance
Backup)
6. Electric Resistance with
7. Dual fueled Hcat Pump
8. Dual-fucled Heat Pump with
Storage

1. No App1iance

2. Gas

3. Electric Resistance

4. Solar

5. Controllable Electric
1. No Appliance

2. Gas Stove

3. Electric Stove 
Table 2-2 (continued)

TECHNOLOGIES BY END USE

End Use

5. Residential other

6. Commercial Space Heat

7. Commercial Air Conditioning

8. Commercial Other

9. Industrial

10. Transportation (Automobile)
Technology

1. No Appliance
2. Electric

1. No Appliance

2. Gas/0il Furnace

3. Electric Resistance

4. Electric Heat Pump

1. No Appliance

2. Gas

3. Electric Central

4. Electric Heat Pump

5. Electric Central with Storage

1. No Appliance

2. Other

1. No Appliance

2. Unmanaged Electric

3. Managed Electric

4. Interruptible

1. No Appliance

2. Nonelectric

3. Electric 
Tabie 2-3

\section{DAY TYPE CATEGORIES}

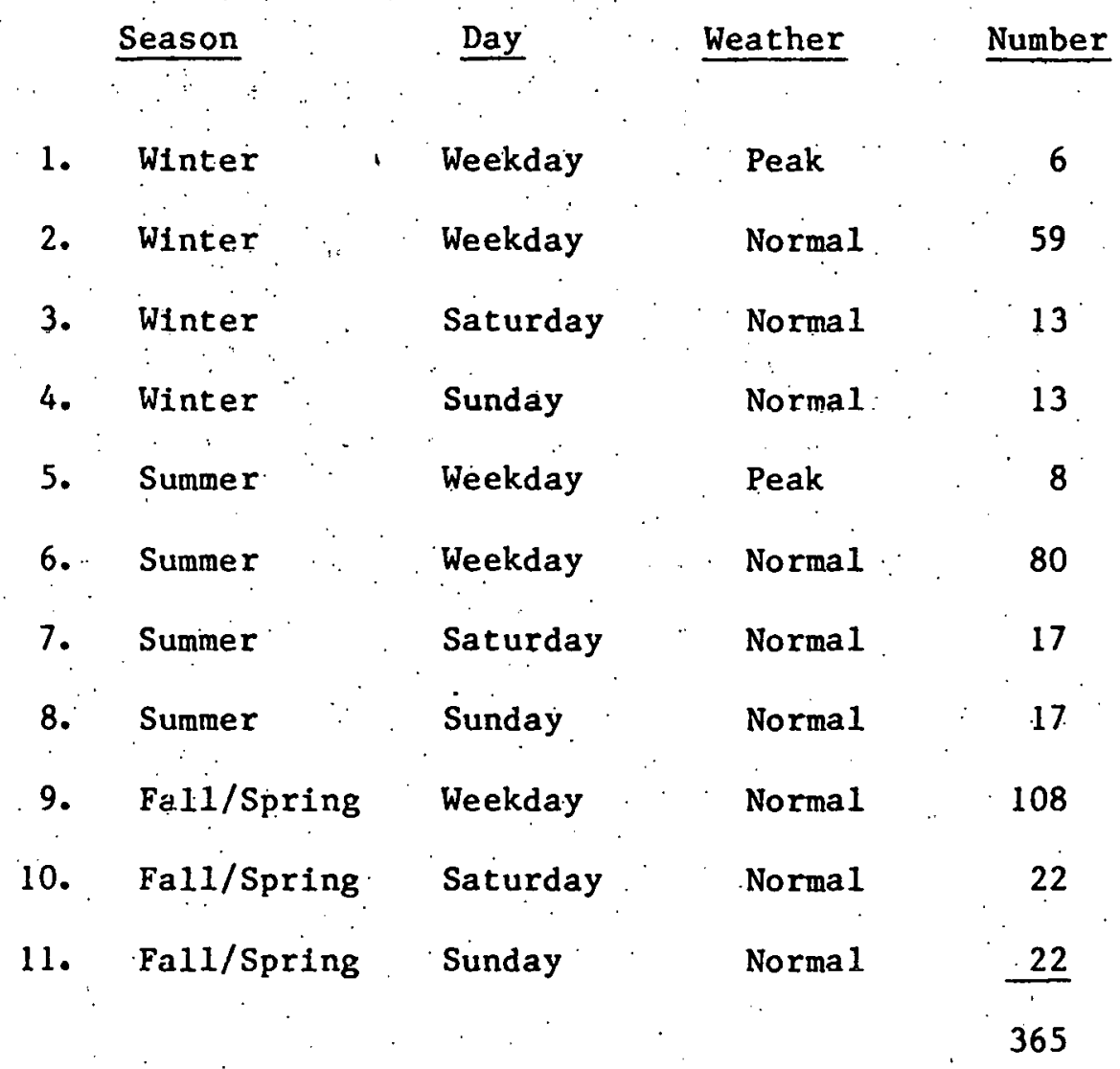


$\begin{array}{lll}\circ \quad \text { Winter } & =\text { December through February } \\ \circ \quad \text { Summer } & =\text { June through September } \\ \circ \quad \text { Fall/Spring } & =\text { March through May plus October and November }\end{array}$

The days of the week are divided into weekdays, Saturdays, and Sundays. Weekdays in the winter and summer are further divided by weather conditions into peak and normal days. Peak days correspond to the coldest and hottest $10 \%$ of weekdays in their respective seasons.

Finally, in the demand submodel, the time-of-day dimension is simply the 24 hours of the day. However, in order to reduce computational requirements, time of day in the load management model and the capacity expansion model is reduced to 12 two-hour periods.

DEMAND SUBMODEL

The purpose of the demand submodel is to estimate future system load shapes and load duration curves. This is accomplished by three submodels:

1. Demand Growth Submodel.

2. Energy Alloçation Submode1

3. Load Shape Construction Submode1

Figure 2-2 shows the submodels and the sequence of calculations that determine system load shapes. Appendix A presents their mathematical formulation. The calculations start with the demand growth submodel, which takes initial estimates of energy by end use and technology together with exogenously specified growth rates and technology market shares to determine the amount of energy in each end use and technology in a given future year. The energy allocation submodel then divides this energy by season, day of week, and weather condition (peak and normal). In the next step, the load shape construction submodel takes the energy by each end use, technology, and day type and allocates it hour by hour using hourly load profiles given for each technology. The submodel then adds all the resul- 


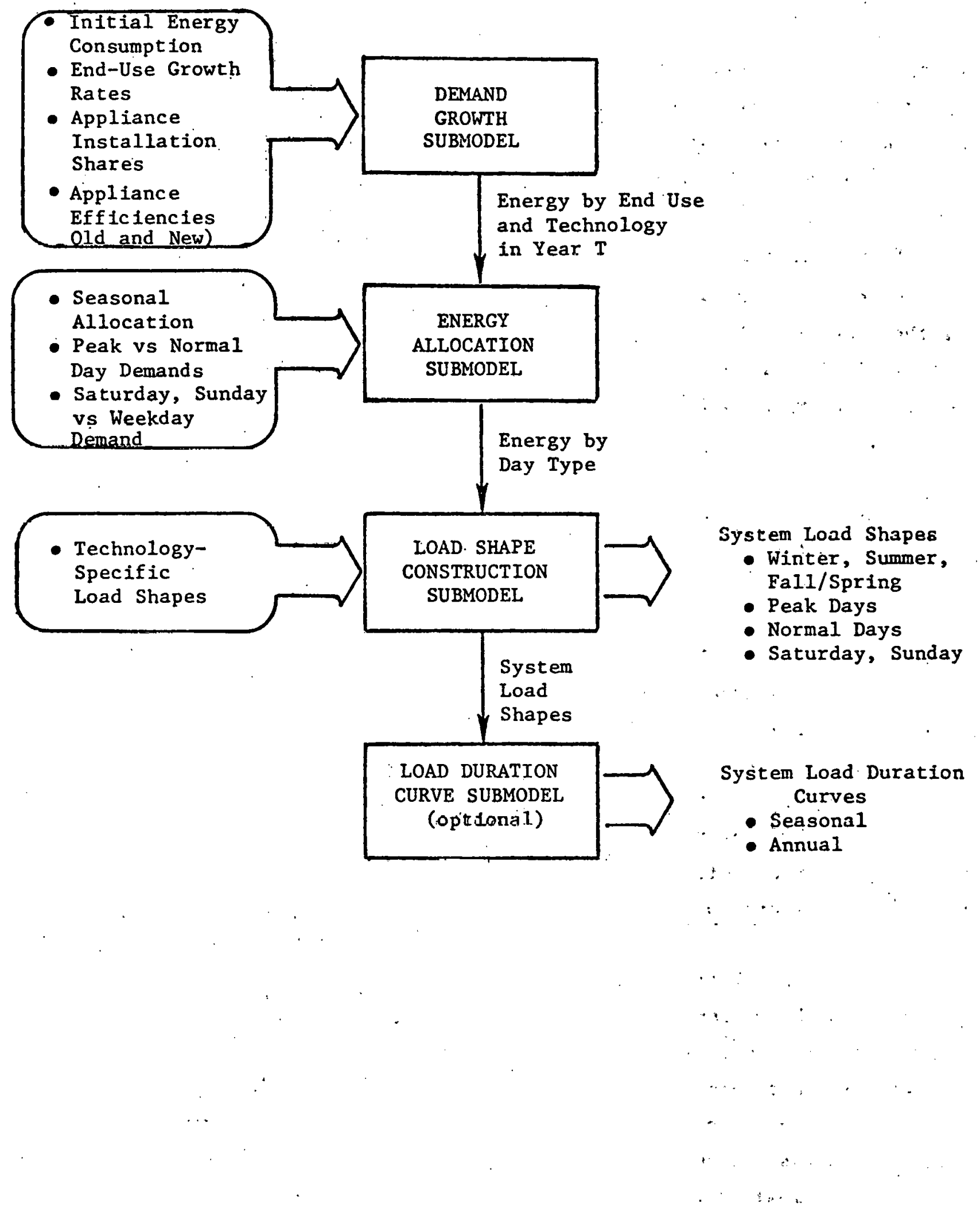

Figure 2-2. Components of Demand Model. 
tant load shapes for each day type to determine the system load shape for each day type. Finally, the annual load duration curve is calculated by assembling the loads in decreasing order, accounting for the number of days represented by each day type.

Demand Growth Submode1

Figure 2-3 shows the structure of the demand growth submodel. The figure shows the operations that are performed on one of the ten end uses; each of the others is done in exactly the same way. The model operates one year at a time starting with an initial year and continuing to the year desired for projection.

For the starting year, initial conditions specify the amount of energy in the end use and the split of that energy by technology. The circles at the top of the figure represent the amount of energy allocated to these technologies, which are numbered 1 through $n$. Each year, total end-use energy grows because of growth in population, building stock, and industrial activity. This new demand, represented by the circle at the bottom of the figure, is then allocated to the competing technologies according to the fractions called installation shares. In this model, the installation shares are given as input. Thus, Implications of changes in the shares must be studied by sensitivity analysis. In a higher-level model, the Installation shares could be determined by the economics of each technology and models of customer behavior.

In addition to installation shares from new demand, the share of energy by technology can change because of conversions from one technology to another. In the model, each technology has a given average service life. At the end of the service life, the technology must be replaced by either the same technology or one of the other technologies. This process is represented in the figure by the lines denoted "Replacements" and "Converslons." For example, when an oll furnace wears out, it could be replaced by another oil furnace or by one of several alternatives, including an 


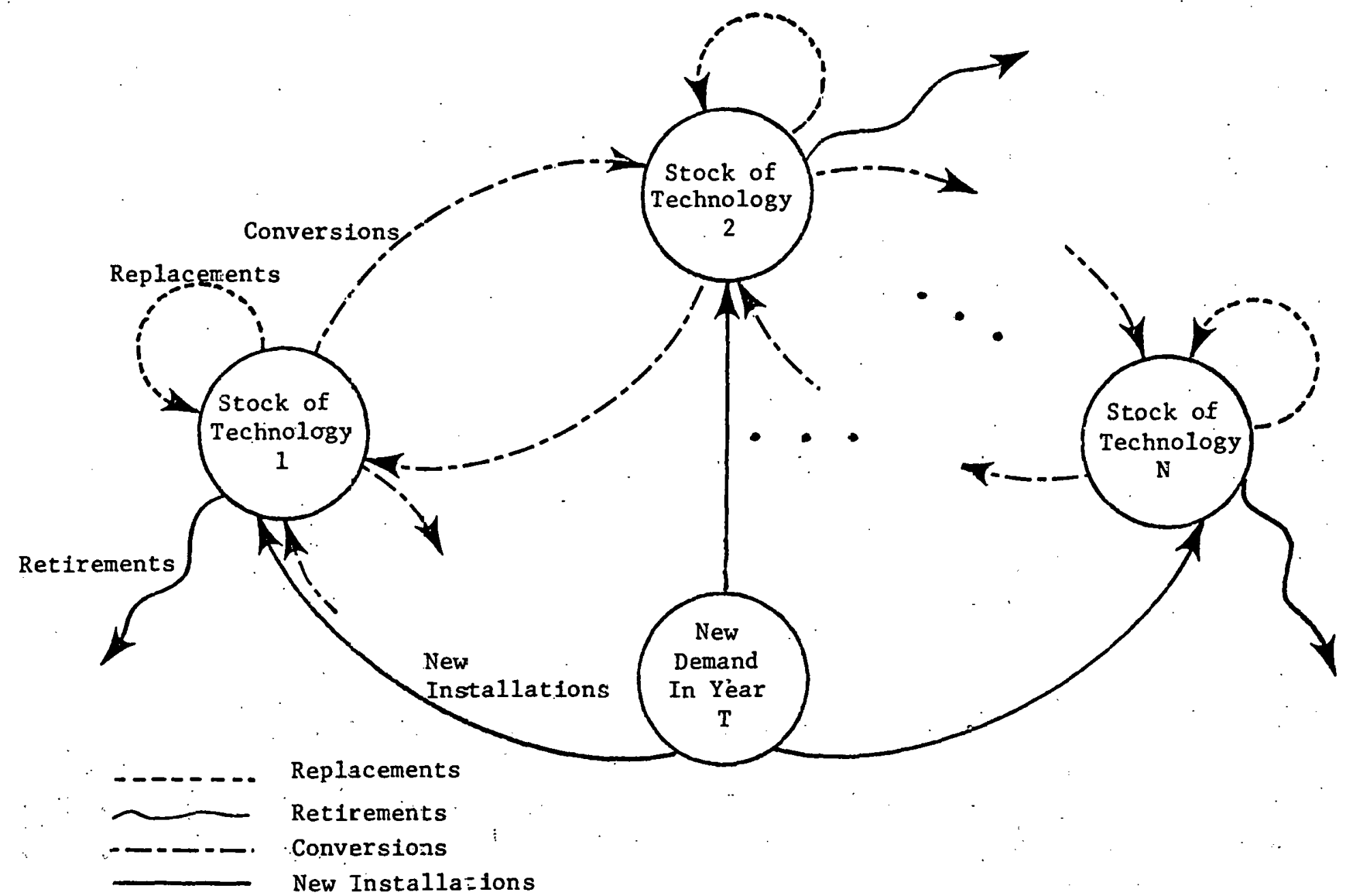

Figure 2-3. Demand Growtt Submodel 
electric furnace, a heat pump, or perhaps an electric furnace with an energy storage system. In this analysis, the fractions of replacements allocated to competing technologies are given as input. However, it is assumed in base cases that replacements are usually made by the same technology. Specific exceptions are made in the sensitivity analysis.

Retirements, shown as wavy lines in Figure 2-3, represent the final source of change in the demand growth submodel. Retirements correspond to discontinued use or demolition of old housing or other bulldings. While retirement has been specifically included in the model, its effect is small and can be thought of as a reduction in growth rates.

Along. with the energy. by end use and the technology market shares, the demand growth submodel maintains a factor representing the average efficiency of installed technologies. If new technologies have higher efficiencies than the older versions, average efficiency is updated as a weighted average of the new and the old. This operation is done in this submodel because of its dependence on the growth and shifts of technologies:

\section{Energy Allocation Submodel}

The energy allocation submodel has two basic purposes. First, it allocates end-use energy by technology and then by season, day of week, and peak and normal day categories.: Second, it determines the actual amount of electric energy represented in each technology and day type by multiplying by the Inverse of the efficiency and by the fraction of the energy in the technology that is electric. Also at this stage the units are converted from $10^{12}$ Btu to thousands of megawatthours (MWh).

The energy allocation function is illustrated in Figure 2-4, which shows the process as a tree in which energy is divided progressively at each level. In the figure, only the topmost winter and summer branches have been drawn completely. Actually, each branching point is connected to all 


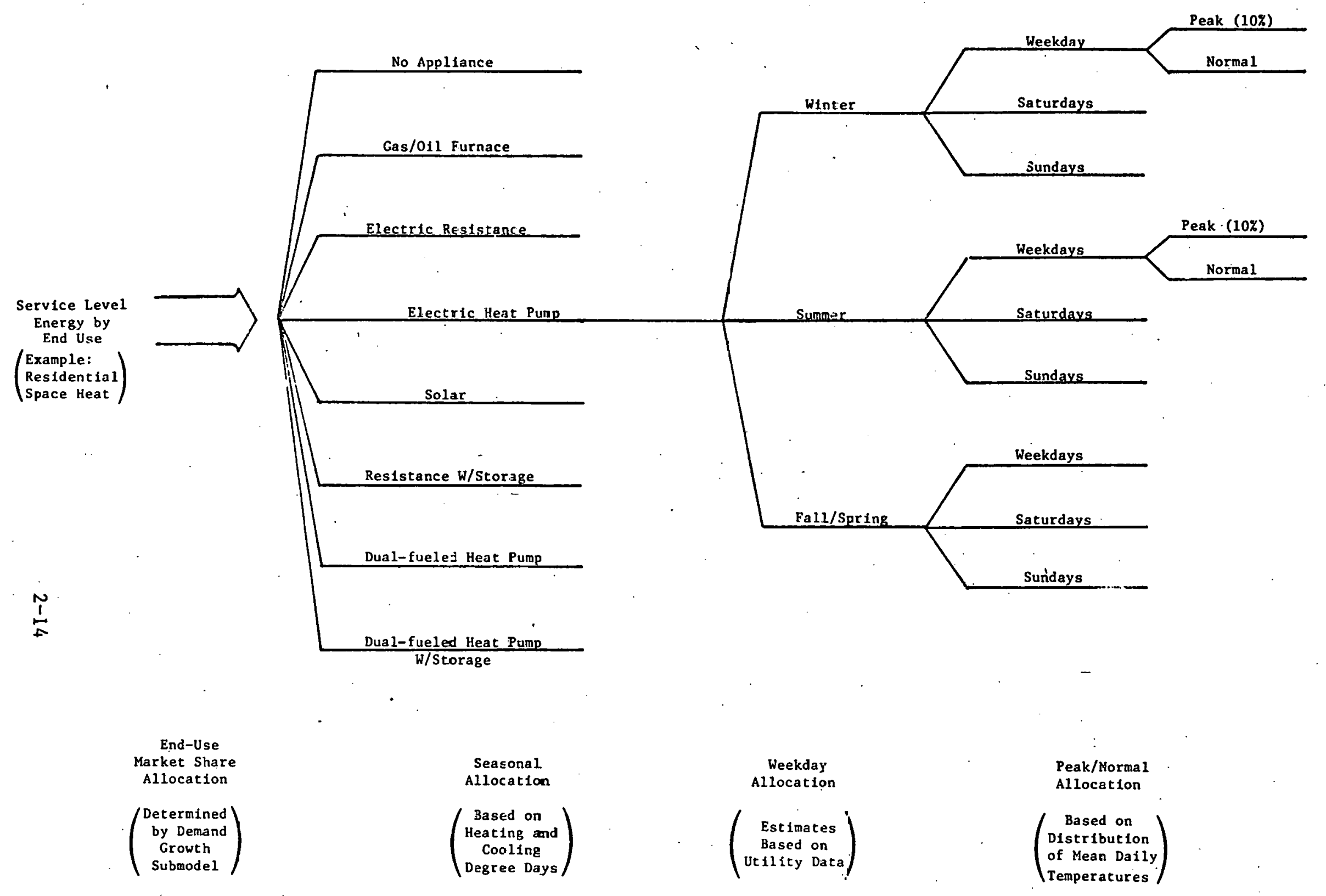

Figure 2-4. Energy Allocation Submodel: Division of Energy by Season, Weekday, and Weather (Illustrated with residential space heat, electri= heat pump, end use, and technology) 
preceding branches. The spilt in the first level is determined by the technology market shares, which were calculated by the demand growth submodel. The next three levels of split are specified as inputs. In general terms, the seasonal split is based on weather data (i.e., heating and cooling degree days by season), the number of days per season, and any special seasonal characteristics of end-use technologies. The split between weekdays, Saturdays, and Sundays is based on data from electric utilities. The allocation between peak and normal days is based on the distribution of mean daily temperature converted to energy requirements. The basis for this split is described more fully in Reference [2].

\section{Load Shape Construction Submode1}

The load shape construction submodel simply allocates to hour of the day the energy associated with each technology and day type as determined in the previous model. The hourly allocation is done in proportion to representative load shapes for each technology. In this process, it is assumed that the load shapes are independent of total energy use. For example, doubling the dally energy doubles the energy used during each hour. A.1though this approach gives a good approximation, there are situations in which it is not strictly true. For example, limited capacity in some air conditioning equipment can lead to a flattening of load shape on very hot days. Therefore, the results of this model may tend to exaggerate peak days somewhat.

Once the energy is allocated by hour, the system load shapes can be constructed simply by summing the resuitant shapes first over technologies within end use and then by end uses. This process is shown in Figure 2-5.

Finally, the annual load duration curve is obtained by combining the approprlate number of each of the eleven representative days (given in Table 2-3) to reach a total of 365 days or 8760 hours, then arranging the hourly loads in descending order. 


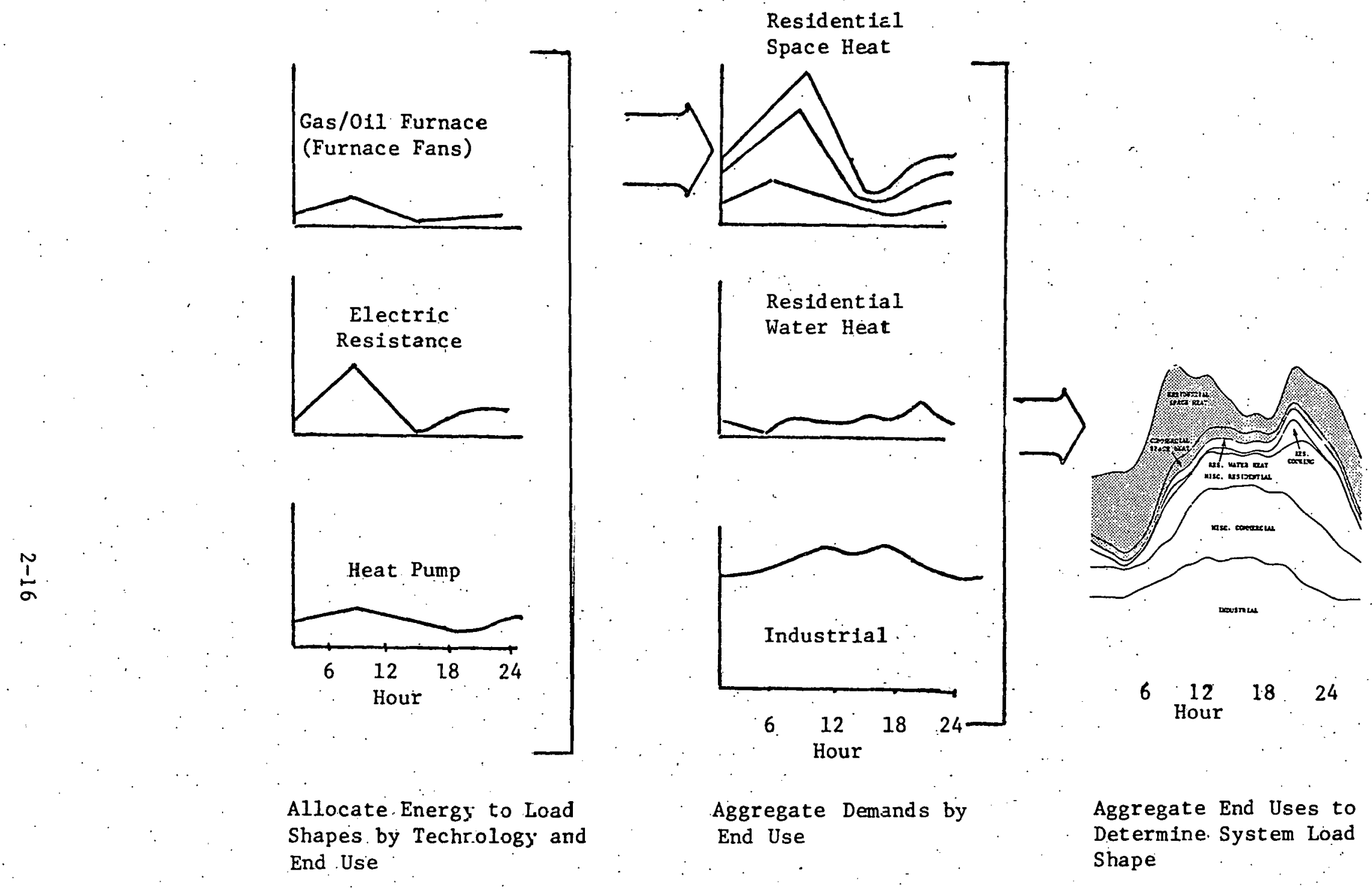

Figure 2-5. Schematic of Load Shape Construction Submodel (Example shown for peak winter day) 
CAPACITY EXPANSION AND OPERATION SUBMODEL

This model's purpose is to determine the mix of generation and storage that minimizes the cost of meeting the load shapes generated by the demand submodel. The results of the model are an indication of the need for intermediate and peaking technologies.

Figure 2-6 is a schematic diagram of the capacity expansion submodel. The model is formulated as a linear program that minimizes the levelized cost of meeting hourly system demands by season and day type. The model optimizes the $m 1 x$ and operation of generating and storage equipment subject to reserve margin constraints, availability and maintenance constraints, and constraints that define the limitations of charging and discharging the storage systems. Appendix C contains a complete formulation of the model.

\section{LOAD MANAGEMENT SUBMODEL}

The main part of the load management submodel is a system of submodels that simulate the effects of time-of-use pricing and customer-owned storage (e.g., residential space heat storage or hot water storage). This system of submodels is referred to in the following paragraphs as the load management submodel. (A separate module simulates the effects of interruptible service to a portion of the industrial load; it is described briefly at the end of this section.)

The calculations used to simulate load management are based on the premise that customers will respond to time-of-use prices in three-ways:

1. They can use storage devices to alter the consumption pattern of electricity.

2. They can choose to change their daily patterns of consumption to reduce expenditures for electricity.

3. They can change the total anount of electricity consumed. 


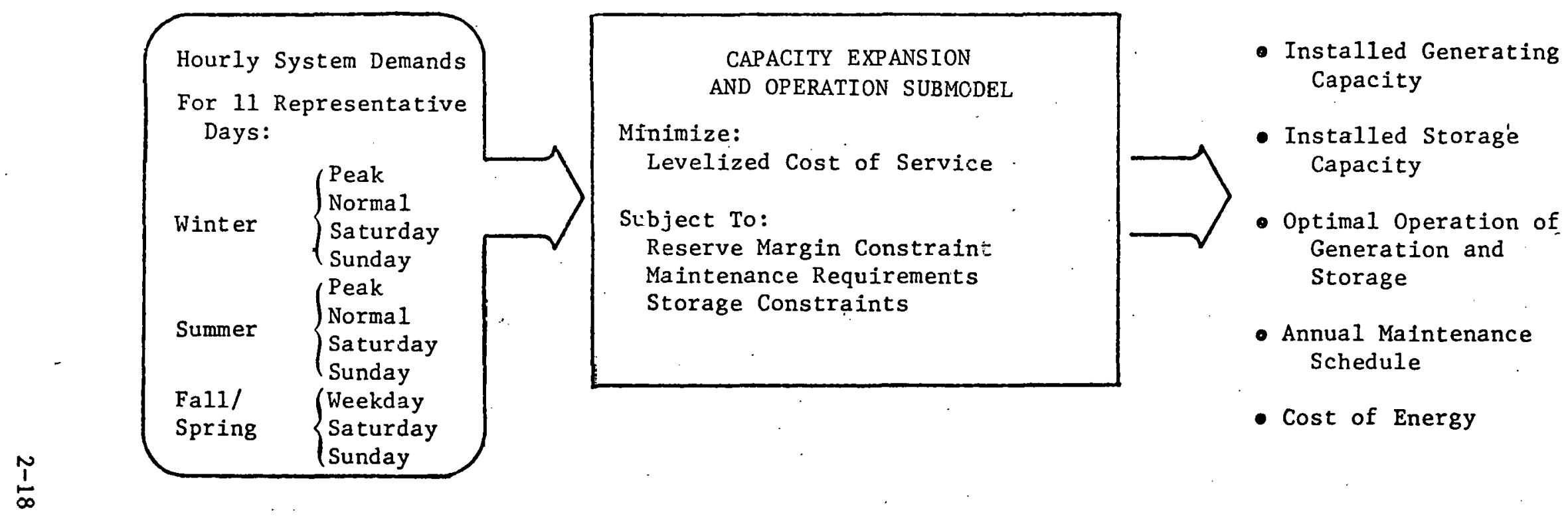

Figure 2-6. Schematic of Capacity Expansion and Operation Submodel 
The speciflc applications of the load management submodel are

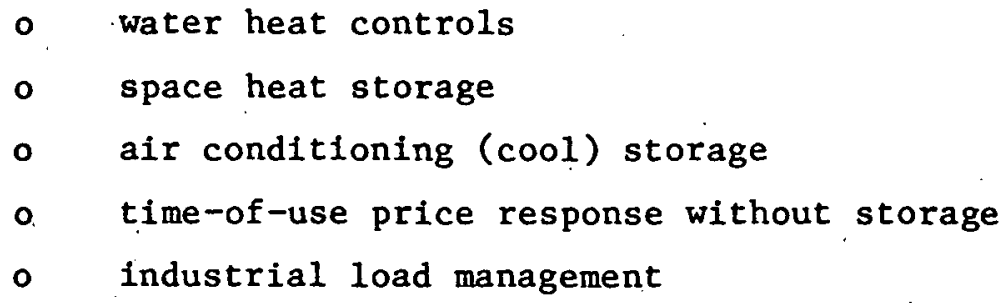

In all of these applications, time-differentiated prices play a role, either as economic incentives or as signals for control action. In modeling time-of-use pricing, prices are assumed to directly affect the behavior of consumers, inducing them to change their patterns of electricity consumption. In modeling energy storage systems, it is assumed that customers can continue to enjoy the benefits of heat and/or cooling when they want $1 t$, but the storage device allows a redistribution of daily electricity purchases. Prices thus serve as an incentive to purchase electricity at those periods of the day when it is least. expensive and store it. In the modeling of water heat control, prices can be viewed as physical signals that direct the timing of water heat to avoid the most expensive periods, which in turu correspond to perfods with the highest system loads. Finally, to simulate industrial load management, it is assumed that a certain fraction of the industrial load can be heavily sh1fted in response to time-of-use rates.

\section{Components of Load Management Submodel}

The load management submodel addresses these applications with a system of three submodels:

1. customer storage submode1

2. time-of-use demand submode1

3. energy demand submode1

The models are described here briefly. Mathematical detafls are contained In Appendix B. The customer storage submodel simulates the operation of a 
customer-owned energy storage device. It determines how energy costs can be reduced by purchasing energy during low price periods and storing it for use during high price periods. The extent of the shifts in purchases is determined by storage efficiency and flexibility (energy capacity and charging capability). The effect of the storage submodel as applied to commercial air conditioning is shown in Figure 2-7.

Time-of-use prices will have two effects. First, people will change the timing of consumption. For example, they might operate clothes dryers in the evening when electricity prices are relatively low rather than during mid-afternoon when prices are high. In this case, the toral amount of electric energy used to dry clothes is the same; only the timing is changed. The second effect of time-of-use prices is to change the total amount of energy used for a specific purpose, such as air conditioning. With an end use such as air conditioning, time-of-use pricing raises costs to the customer, and there is little or no advantage to changing the hourly pattern of consumption (i.e., alr conditioning is needed during those hours when $1 \mathrm{t}$ 'is hot).

The time-of-use demand submodel simulates customer response to relative differences in prices throughout a given day. This submodel is used in conjunction with the energy demand submodel to determine the total effect of time-of-use pricing. Specifically, the time-of-use demand submodel takes a given amount of energy and determines how it is distributed throughnut the day, while the energy demand submodel determines the total amount of energy consumption during the day. Two effects can be modeled with this approach. First, the demand on each day levels off because prices during peak periods are higher than the prices during off-peak periods. Second, because the average price is higher on peak days than on normal days, total energy demand on peak days decreases relative to off-peak days.

The extent of the effect of time-of-use pricing is determined by the settings of price elasticity parameters. 


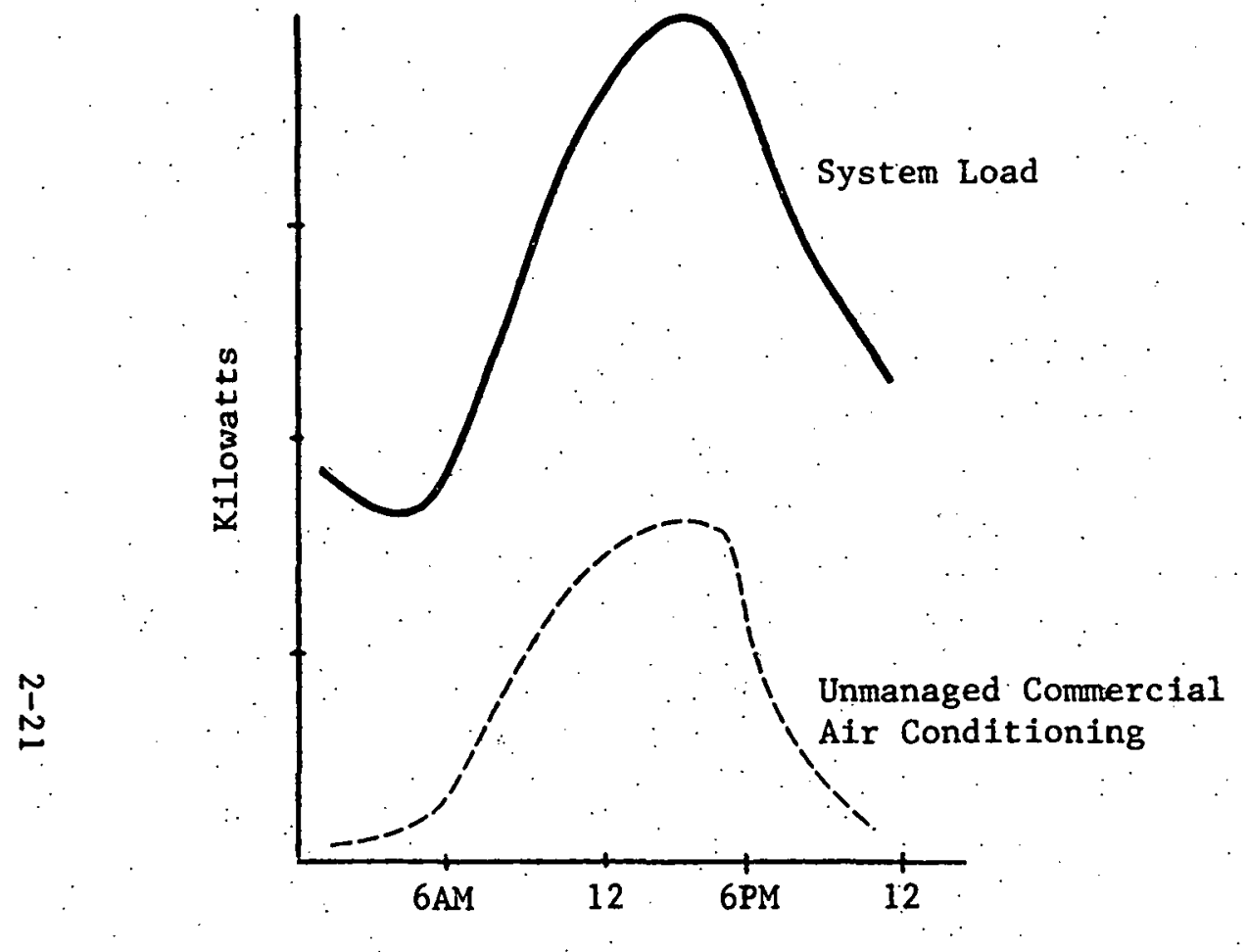

BEFORE LOAD MANAGEMENT

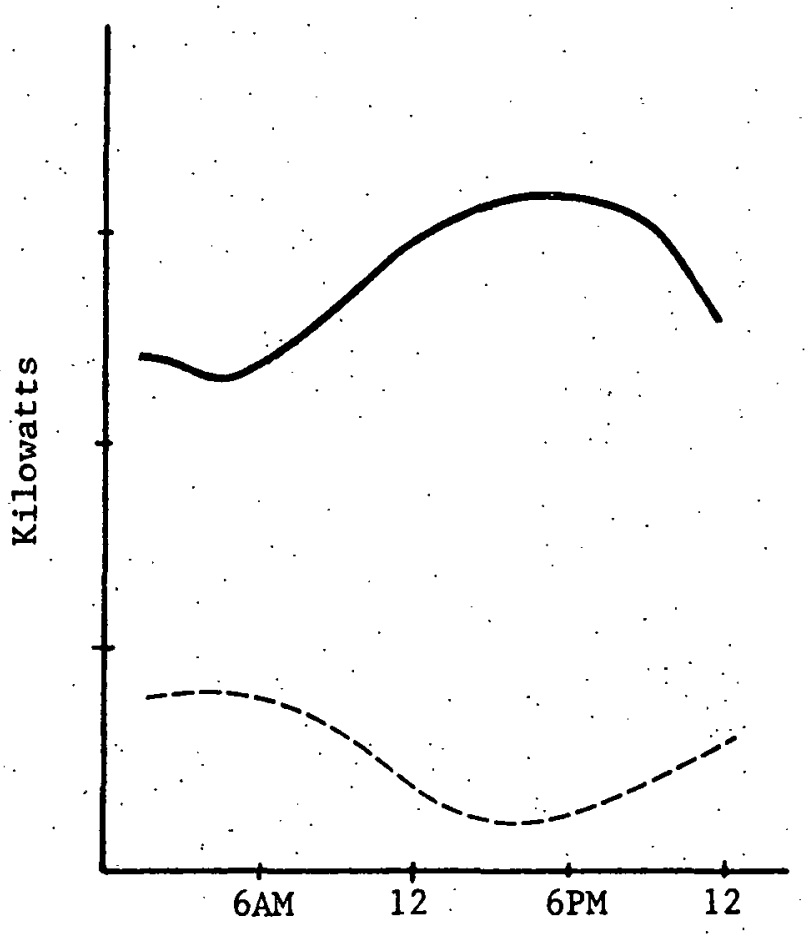

SYSTEM. DEMAND AFTER APPLICATION OF ENERGY STORAGE IN CONJUNCTION WITH COMMERCIAL AIR CONDITIONING

Figure 2-7: System Load Before and After Application of the Load Management Algorithm (Commercial Air Conditioning Example) 
Elasticity is an economic concept that describes how customers change their consumption in response to price changes. In general an elasticity $\varepsilon$ is the percentage of change in quantity demanded divided by the percentage of change in price. Stated another. way, the change in demand caused by a change in price can be found by the following formula:

$\begin{aligned} & \text { Percentage } \\ & \text { of Change } \\ & \text { in Demand }\end{aligned}=\varepsilon \cdot x \quad \begin{gathered}\text { Percentage of } \\ \text { Change in } \\ \text { Price }\end{gathered}$

In the energy demand submodel, the elasticity parameter is called the energy elasticity. It is the percentage of change in total energy consumed in a day divided by the average price of electricity for that day. In the time-of-use demand submodel, the elasticity parameter is called the hourly elasticity. Its value is approximately the percentage of change in consumption during a period of the day divided by the percentage of change in the price during that period, with prices in all other periods held. constant. Of course, in this submodel, if demand in one period increases, demand in other periods decreases so that the total energy remains constant. In addition, more than one price may change simultaneously. To determine the entire effect, an array of cross-price elasticities is used. These elasticities relate the change in consumption in each period to changes in prices of all other periods. A formula for this array is derived in Appendix $B$.

OPERATION OF THE LOAD MANAGEMENT MODEL

The operation of the load management model is shown in Figures 2-8 and 2-9. Figure 2-8 shows the model completely connected. This configuration would be used for studying the combined effects of customer storage and time-of-use pricing. Figure 2-9 shows how the model can be decomposed into separate storage components and time-of-use components.

With the model fully connected, computations begin in the customer storage submodel. Here, hourly prices are used to determine the proportion of 


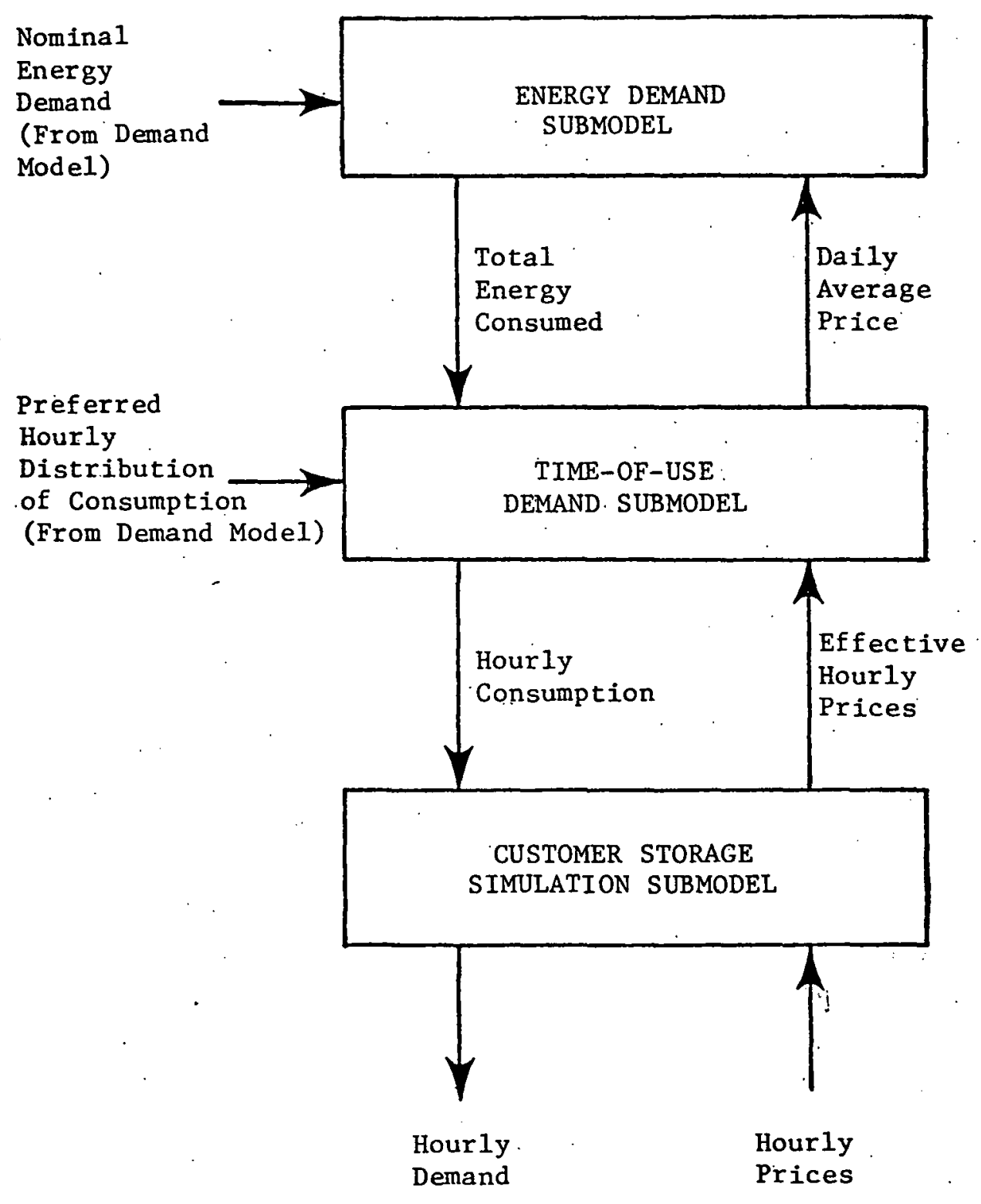

Figure 2-8. Components of Load Management Model 


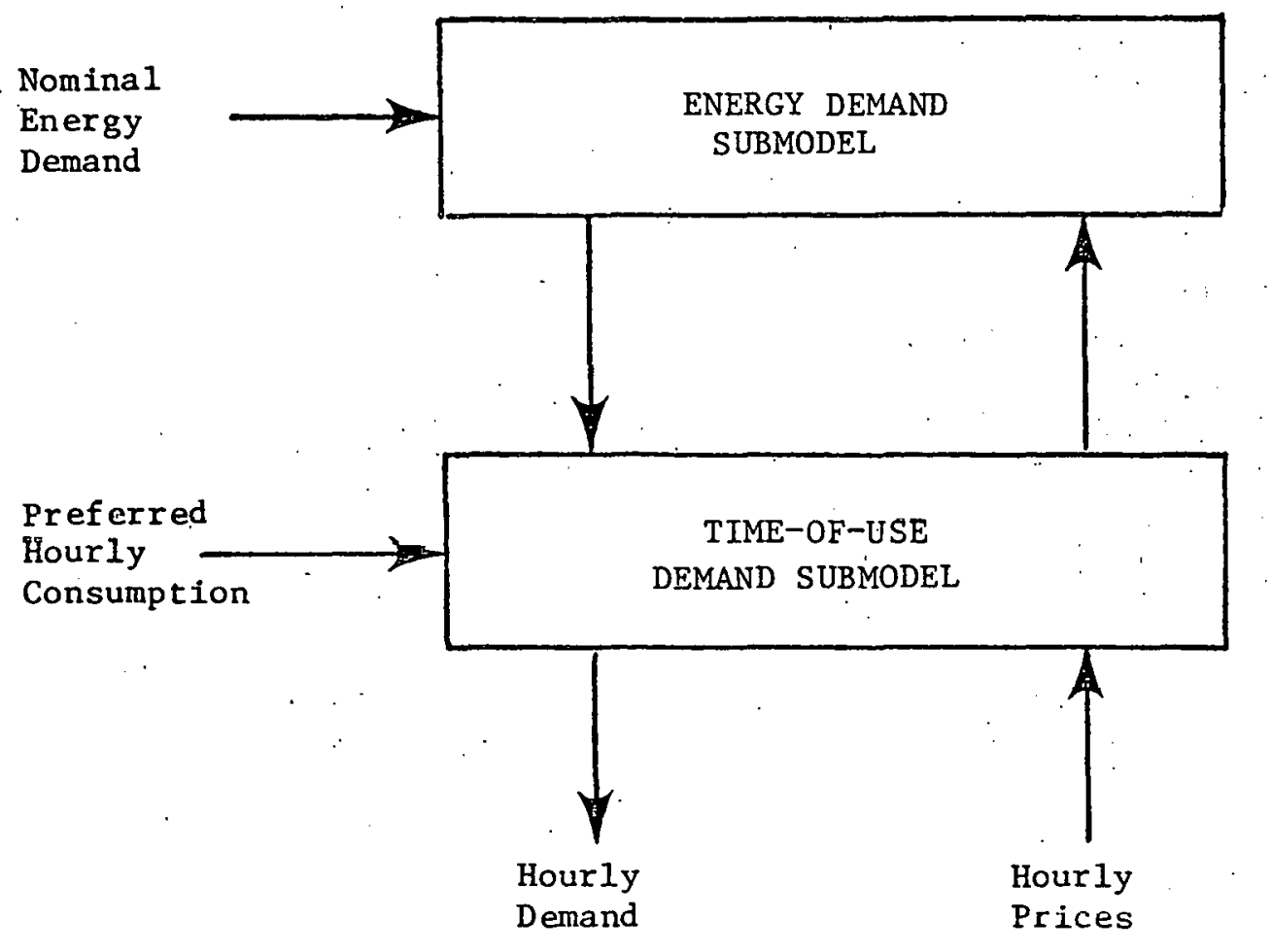

a) Hourly price response without customer storage.

\section{Preferred}

\section{Hourly}

Consumption

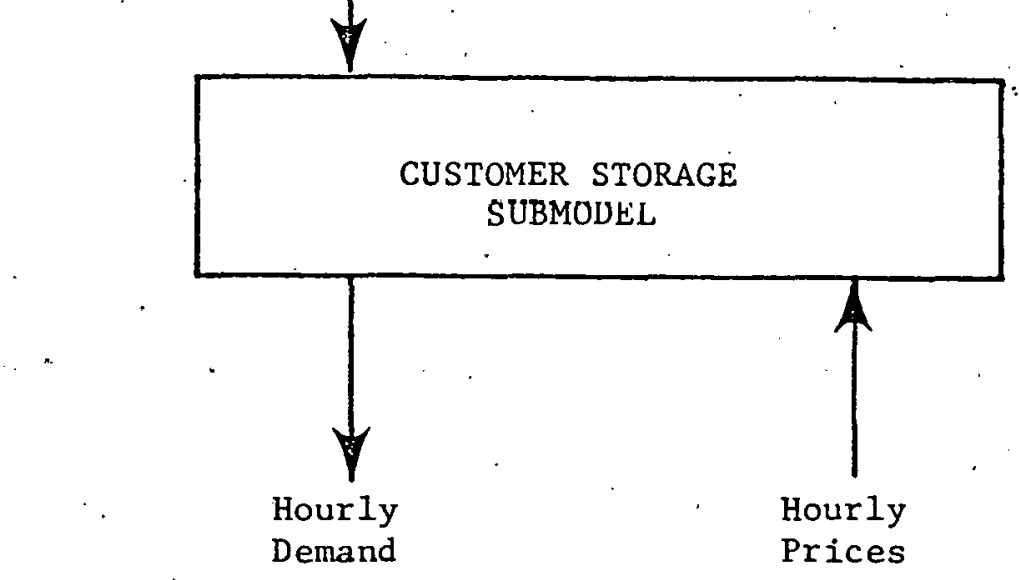

b) Customer storage model without general time-of-use price response (zero hourly demand elasticity).

Figure 2-9. Alternate Modes of Operation of the Load Management Model 
energy used in each time period that is purchased in other time periods. This reallocation of purchases determines effective hourly prices for service energy by time period, taking into account the fact that energy can be purchased at a time different from when it is used and that some efficiency loss may occur. The effective prices are essentially prices of end-use energy as perceived by the consumer. These prices are then input to the time-of-use model, which performs a similar reallocation, this time using the hourly elasticity parameter and a distribution of hourly consumption preferences. After hourly shifts have been computed, a daily average price is determined. This is fed into the energy demand submodel together with a nominal desired level of energy consumption. This submodel uses the energy elasticity to calculate a modified level of energy consumption, which is then passed back to the time-of-use submodel where actual hourly consumption levels are determined. These are then fed down to the storage model, which determines the actual hourly levels of energy demand. In a decomposed model, as in Figure 2-9, the computations involve only the separate components.

The final step in computing the effect of the load management model is the computation of hourly prices consistent with hourly demands. This is done with a process shown in.Figure 2-10. Since the objective of load management is to level loads and thus to reduce generating costs, it is important that prices be consistent with system demands and therefore consistent with costs. For example, when the system load is high, the price should be high. Our simplifying assumption is that prices are set equal to short-run marginal costs (operating costs), which. in turn are approximated by simple linear functions of Figure 2-11. To be consistent, the hourly demands shown in Figure 2-10 should result in prices that when fed back to the load management model produce those original demands. To determine a consistent set of demands and prices, it is necessary to begin with pre-time-of-use demands given and iterate in the loop shown in the figure until a consistent set of prices and demands is found. 


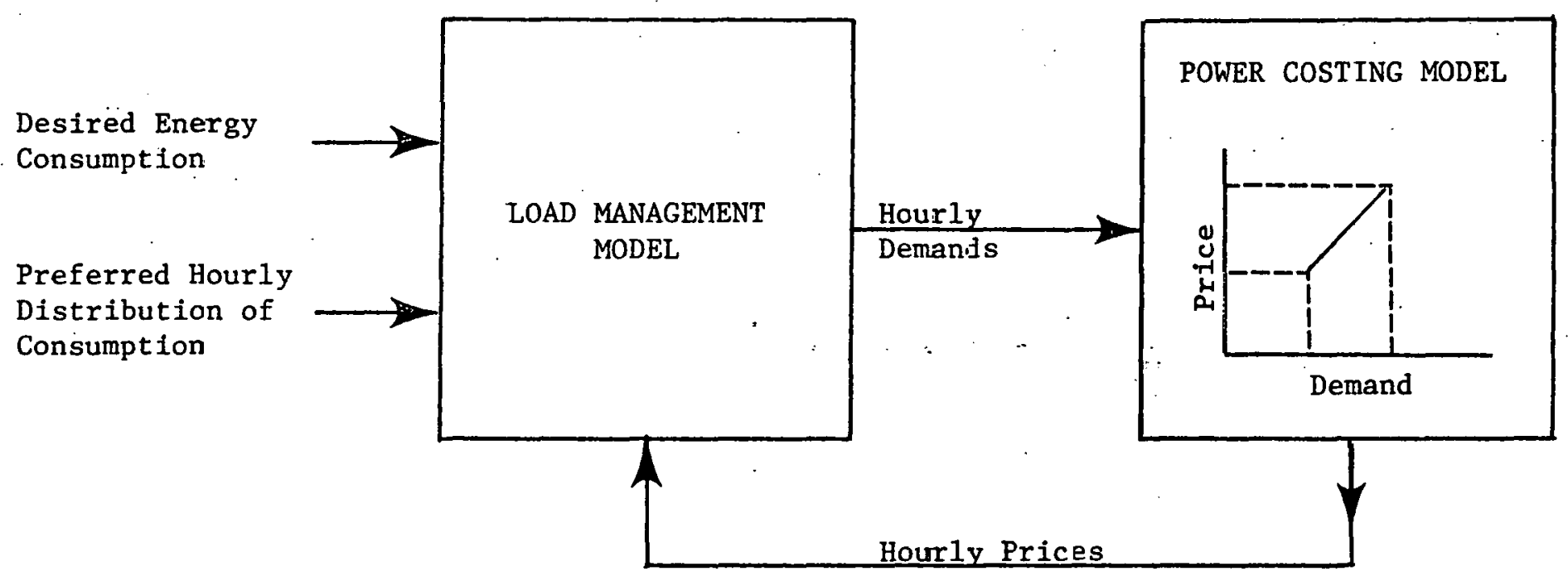

EQUILIBRIUM HOURIY DEMANDS AND PRICES ARE

FOUND BY ITERATING

Figure 2-10. Illustration of the Solution Procedtre for the Load Management Model 


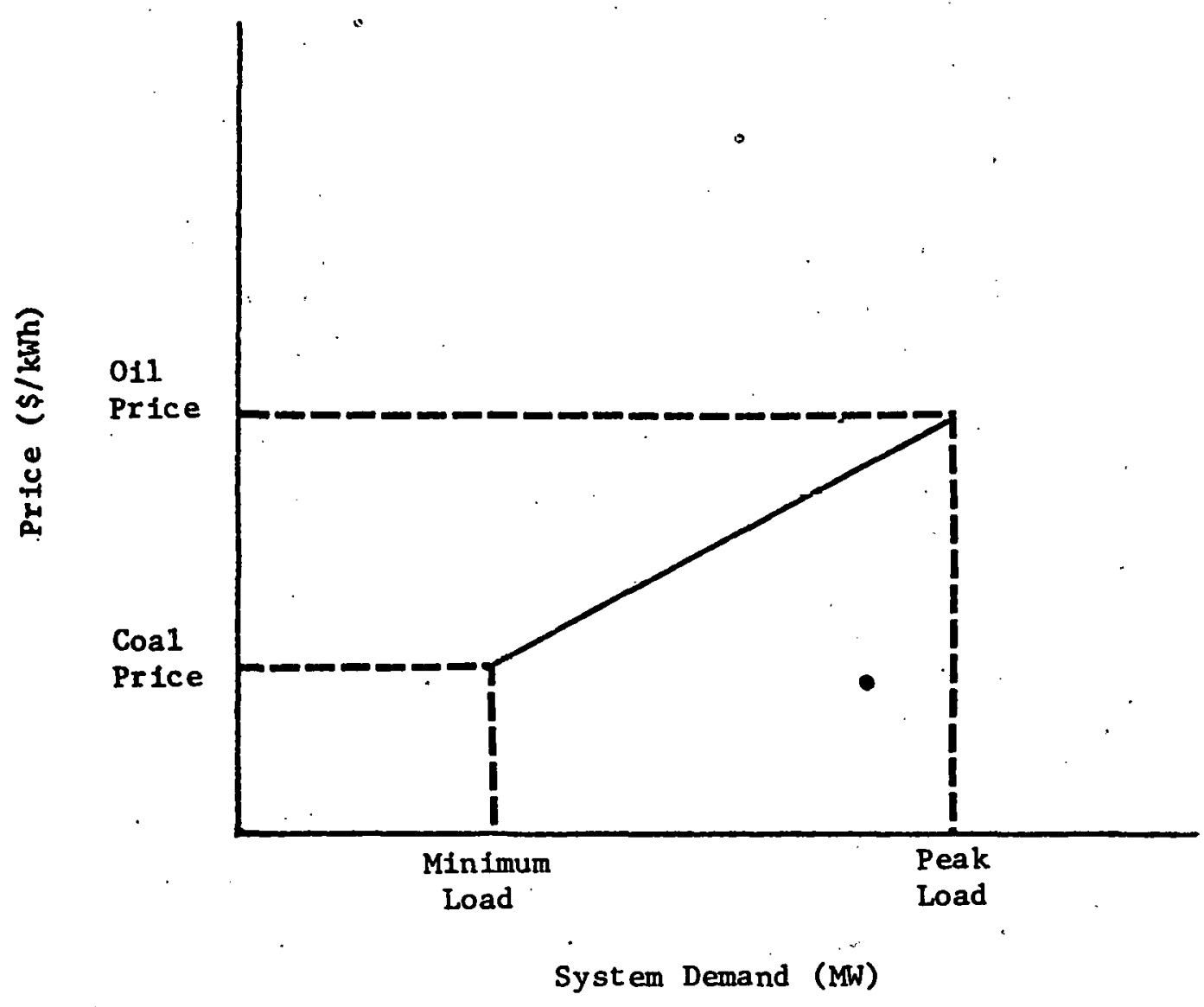

Figure 2-11. Simplified Power Costing Model 


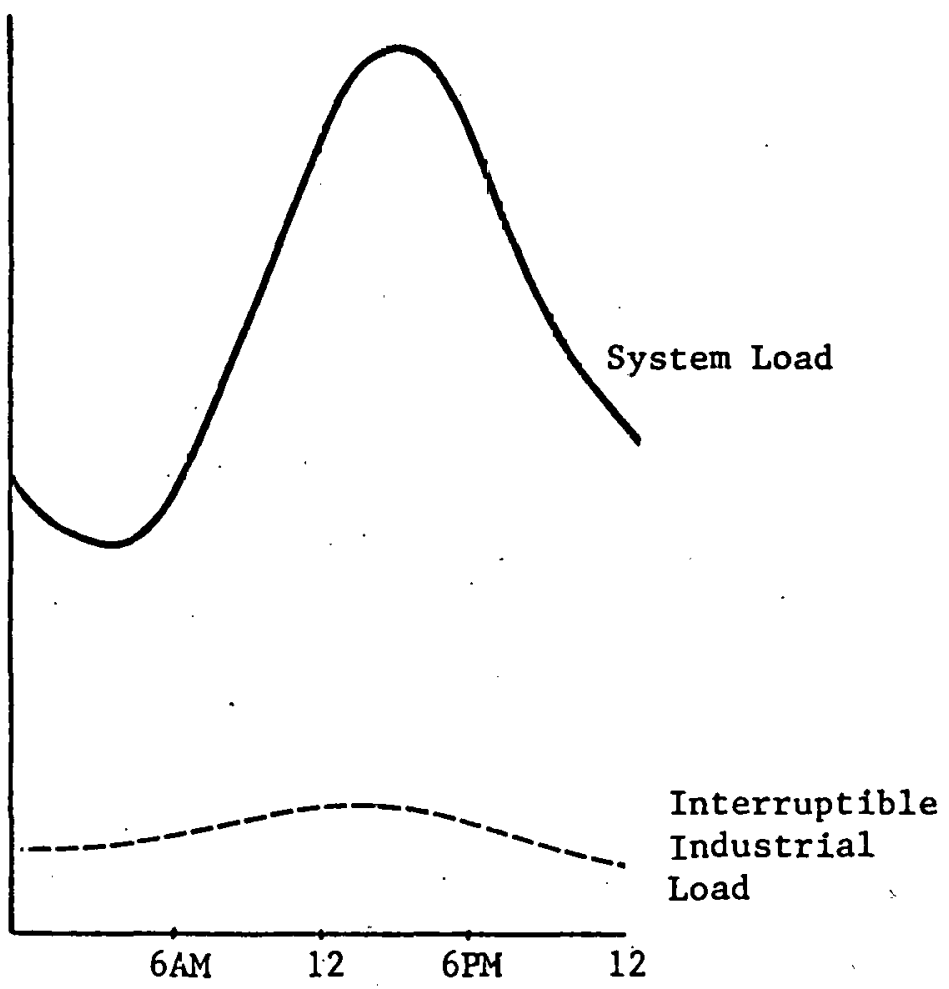

BEFORE INTERRUPTION

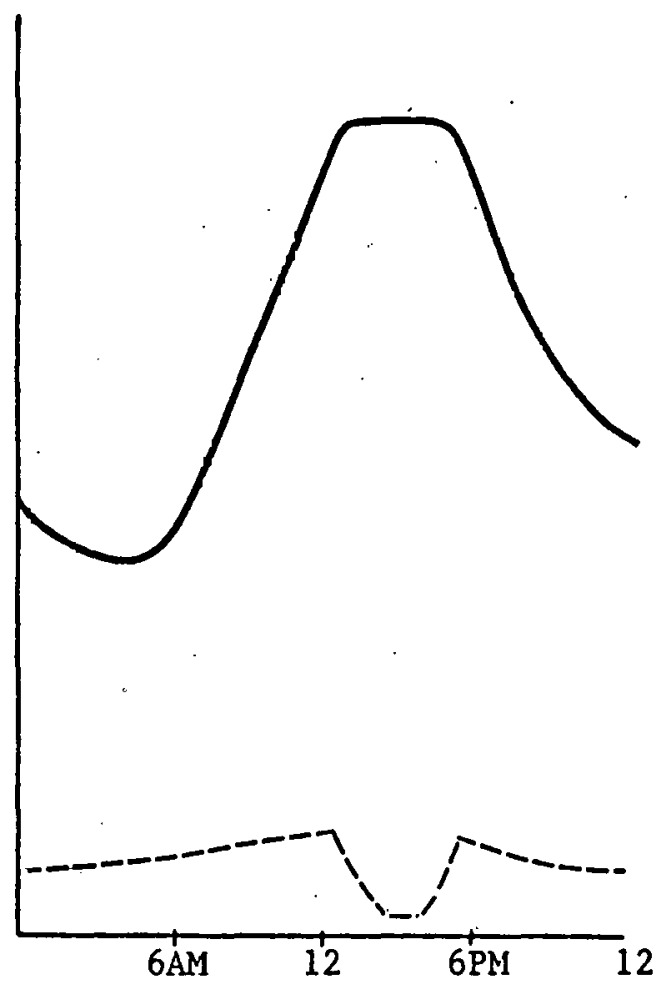

SYSTEM LOAD AFTER INTERRUPTION OF PORTION OF INDUSTRIAL LOAD

Figure 2-12. System Load Before and After Application of Interruptible Service Submode1 
To complete the pricing and costing cycle of Figure 2-10, it is. necessary to determine the cost of producing power during each time period. The capacity expansion model could be used for this purpose, since the true marginal costs of electricity are reflected in the Lagrange multipliers of the linear program at its solution. However, computing with these multipliers would be very expensive. Therefore, to complete the load management cycle, the simplified power costing model shown in Figure 2-11 is used. Here, the cost of power in any given period is assumed to be a linear function of the system load as shown.

This is clearly an approximation, since production costs usually increase more steeply as the system peak is neared. Also, the marginal costs of new capacity additions are not reflected in this simple approximation. However, it is a useful way of simulating the feedback between demand level and the short-term marginal cost of energy.

\section{INTERRUPTIBLE SERVICE SUBMODEL.}

A simple algorithm separate from the load management model is used to simulatc the impact of interruptible service. The operation of this model 1s shown in Figure 2-12. In the model, a certain end use or a portion of an end use. is assumed to be interruptible. In the case shown, about $25 \%$ of the industrial load is taken as interruptible. It is also assumed that the interruption is limited to a maximum duration, here about four hours, and it can be applied only on peak days, whether in summer or winter. The algorithm essentially chops the system load on the system peak day subject to the maximum energy that can be interrupted and the maximum duration. In strongly summer peaking systems, only the summer peak is interrupted. In systems in which the summer and winter peaks are relatively even, both the summer and winter peak days may be interrupted. 


\section{CONCLUSION}

This concludes the general discussion of the models used to simulate the impact of changes in electricity demand patterns and load management. Details of model formulation and data bases are contained in Appendix A through Appendix E. 
Section 3

LOAD SHAPE ANALYSIS

This section summarizes the sensitivity analysis and the analysis of load management programs that were performed with the electric load analysis models. The section begins with a brief discussion of the base case data and assumptions along with a comparison of base case results of the North Central and South Central regions. Next a series of sensitivity results is presented. The sensitivity analysis emphasizes growth rates and saturation rates of existing and new technologies, particularly for weather-sensitive loads, such as space heat and air conditioning. Finally, the load management results are presented, emphasizing the use of end-use energy storage systems and the effects of time-of-use pricing.

BASE CASES

Tables 3-1 and 3-2 summarize the base case data for the North Central and South Central regions, respectively. A complete presentation of the data, some of which is specific to certain technologies, can be found in Appendix D.

The 1980 allocation of energy by end use and electric appliance saturations were taken from Brookhaven, Regional Reference Energy System [4]. These energy levels, which correspond to those in 1972, were escalated by $2 \%$ per year in all sectors to create a base case for 1980 .

The sector growth rates from 1980 to 2000 are based on estimates used in residential and commercial sector models developed by Oak Ridge National Laboratories $[5,6]$, and are consistent with U.S. Bureau of the Census, 
Table 3-1

SUMMARY OF BASE CASE DATA ${ }^{a}$

NORTH CENTRAL REGION

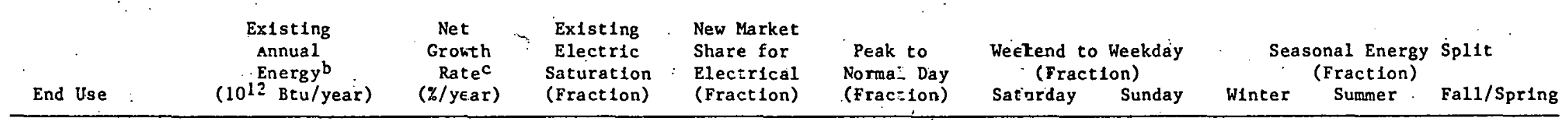

\section{Resident1al}

$\begin{array}{lr}\text { Space Heat } & 1326 \\ \text { Water Heat } & 341 \\ \text { Adr Conditioning } & 415 \\ \text { Ccoking } & 70 \\ \text { Other } & 242\end{array}$

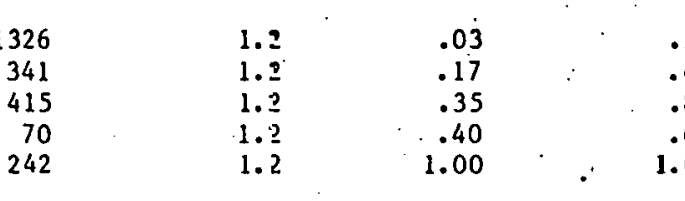

$\stackrel{\omega}{1}$

\section{Commerclal}

Space Heat

562
307

2.5

Other.

307
324

2.5 .

.00

.00
.50

.50
1.00

\section{.06}

.90

.50
.46
.80
.65

2.2

1.00

$1.00^{\circ}$

1.5

.00

.00

Saturday Sunday

Summer

Transportation

510

(1.

.

$\begin{array}{ll}1.40 & 1.08 \\ 1.00 & 1.03 \\ 2.00 & 1.08 \\ 1.00 & 1.008 \\ 1.00 & 1.03\end{array}$

$\begin{array}{ll}1.08 & 1.00 \\ 1.03 & 1.00 \\ 1.08 & 1.00 \\ 1.00 & 1.00 \\ 1.03 & 1.00\end{array}$

.54
.25
.00
.25
.25

.00
.33
1.00
.33
.33

.46
.42

.42

.00

.42

$\overline{a_{A} 11}$ base case energy and saturation data are from Reference [4] 1972 data. Tc simplify exposition; base case assumes no fuel conversions on existing 1nstallations.

bService level energy, e.g., Btu of room heat.

cBased on estimates used in computer runs of Jak Ridge models. 
Table 3-2

SUMMARY OF BASE CASE DATAa

SOUTH CENTRAL REGION

$\begin{array}{cccc} & \text { Existing } & \text { Net } & \text { Existing } \\ & \text { Annual } & \text { Growth } & \text { Electric } \\ \text { Energyb } & \text { Ratec } & \text { Saturation } \\ \text { End Use } & (1012 \text { Btu/year) } & (\% / \text { year }) & \text { (Fractlon) }\end{array}$

New Market
Share for
Electrical
(Fraction)

Peak to

Weekend to Weekday (Fraction)

Seasonal Energy Split (Fract1on)

(Fraction)

Saturday

Fall/Spring

Res1dential

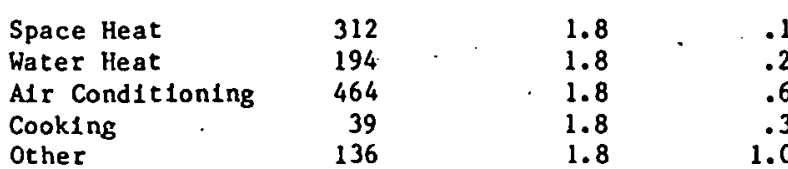

.14
.25
.62
.37
1.00

.50
.46
.80
.65
1.00

1.71
1.00
1.46
1.00
1.00

$\begin{array}{ll}1.08 & 1.00 \\ 1.08 & 1.00 \\ 1.08 & -\quad 1.00 \\ 1.08 & 1.00 \\ 1.08 & 1.00\end{array}$

.66
.25
.00
.25
.25

66
.25
.00
.25
25

.00
.33
.80
.33
.33

.34
.42

1.00

.25

.33

.20

Commercial

Space Heat
Alr Conditioning
Other.

278
446
198

$\begin{array}{lr}3.1 & .00 \\ 3.1 & .04 \\ 3.1 & 1.00\end{array}$

.06
.95
1.00

1.71
1.46
1.00

.93

.93
.93
.93

\section{.51}

$.51 \quad .66$

$.66 \quad .00$

Industrial

516

2.8

1.00

1.00

1.00

.70

.50

.25

.33

.42

Transportation

287

1.7

.00

.00

1.00

1.00

1.00

.25

.33

.42

a Al1 base case energy and saturation data are from Reference [4] 1972 data. To simplify exposition, base case assumes no fuel conversions on existing Installations.

bservice level energy, e.g., Btu of room heat.

cBased on estimates used in computer runs of Oak R1dge National Laboratory models. 
Series II, bullding estimates. The industrial growth rates are based on an assumed national increase of $2.5 \%$ per year, which is roughly equivalent to the long-term GNP growth projections of the Council of Economic Advisors. The growth rate in automobile vehicle miles is taken from [4].

The base case saturations of electric space heat, water heat, air conditioning, and cooking are based on national averages; for purposes of simple exposition, the same saturations are used for both regions. Future electricity demand patterns are particularly sensitive to space heat and air conditioning saturations. In the base case, the saturation assumptions are that $50 \%$ of all new residential units will heat with electricity and $80 \%$ ill have air conditioning. It is further assumed that most new residential air conditioning units are central rather than room by a margin of three to one. This has some imporiant luplications, because the diversified daily load shape of room air conditioning tends to be flatter than central air conditioning. One consequence is that for an equal amount of incremental air conditioning energy central air conditioning will contribute more to peak hour demands.

Peak-to-normal daily energy ratios are based on two pieces of information:*

1. The frequency distribution of mean dally temperatures.

2. The relationship between mean dally temperature and heating or cooling demand, measured in degree days.

The temperature discrlbuliui is uocd to dotormine how hot or cold the peak days (hottest and coldest $10 \%$ of all summer or winter days, respectively) are relative to normal days. The heating and cooling demand data are used to transform temperatures into energy demands.

*A detailed description of the method used is contalned in Appendix $D$ of [2]. 
Temperature data for the Detroit Metropolitan Airport was used for the North Central Region, and data from Lone Pine, Arkansas, was used for the South Central Region. Each of these locations has average heating and cooling demands for its respective region.

Weekend-to-weekday energy multipliers are based primarily on data in References [3], [7], and [8].

The seasonal energy splits are based on monthly heating- and coolingdegree-day data for Detroit, Michigan, and Lorie Pine, Arkansas [9]. Summer is defined as the four-month period from June through September. Winter is three months: December, January, and February.

In the base case, it is assumed that there are no new technologies introduced. For example, electric heat is assumed to be conventional resistance, no technologies with storge capability are allowed, and no electric cars are assumed to be in use. Furthermore, no efficiency improvements are assumed. All of these assumptions are modified in one or more sensitivity cases.

Using the base case data, system load shapes corresponding to the North Central and South Central regions were constructed with the load shape model for the years 1980 and 2000. The characteristic features of the base cases for the two regions are shown in Tables $3-3$ and $3-4$.

In 1980 both regions are summer peaking, as indicated by the ratio of summer-to-winter peak. However, the South Central Region is more strongly summer peaking: its ratio of 1.41 compares to the North' Central Region's 1.21. The seasonal load factors of the two regions are very similar, but the annual load factor of the North Central Region is somewhat higher (.58 versus .53). Both the summer-to-winter peak ratios and the annual load factors are consistent with current utility experience, as indicated in Section 1 . 
Table 3-3

COMPARISON OF NORTH CENTRAL BASE CASES (YEAR 1980 AND 2000)

Base Case 1980
Base Case 2000
Difference

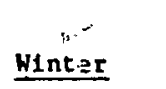

0.745

0.652

$-.093$

\section{Load Factors (Fraction)}

Sammer $\quad$ Aut $/$ Spr

0.578

0.516

$-.062$

0.737

0.788

$-.051$
Annual

0.577

0.546

$-.031$

Table 3-4

COMPARISON OF SOUTH CENTRAL BASE CASES

(YEAR 1980 AND 2000)
Loed Factors (Praction)

\begin{tabular}{|c|c|c|c|}
\hline Winter & Summer & Aut/Spr & Annual \\
\hline 0.7 .27 & 0.578 & 0.735 & 0.525 \\
\hline 0.657 & 0.526 & 0.743 & 0.471 \\
\hline-.050 & -.052 & .008 & -.054 \\
\hline
\end{tabular}

Seasonal Peak Ratios

Growth Rates (\%/Year)

Energy Peak

$0.00 \quad 0.00$

$2.84 \quad 3.13$

$1.041 \quad 0.688$

$-.173 \quad-.225$
Base Case 2000

DLfference
Base Case 1980
Seasonal Peak Ratios

Spr/win

0.943

$.010 \quad-.120$ $\begin{array}{llll}1.415 & 0.943 & 0.00 \\ 1.425 & 0.823 & 3.12 & 3.68\end{array}$
Growth Rates (\%/Year)

Energy Peak

$0.00 \quad 0.00$ $\begin{array}{llll}1.415 & 0.00 & 0.00 \\ 1.425 & 0.823 & 3.12 & 3.68\end{array}$ 
A comparison of the base cases for 1980 and 2000 reveals that in the North Central Region seasonal peaks become almost evenly balanced between summer and winter by the year 2000; the summer-to-winter peak ratio drops from 1.21 to 1.04 . This change is due mainly to the assumed addition of a substantial amount of residential electric space heat ( $50 \%$ of all new residential installations) and the large space heat energy requirement in the North Central Region. However, in spite of the movement toward seasonal balancing, the seasonal as well as the annual load factors drop. In particular, the annual load factor decreases from .58 to .55, a drop of three percentage points. This is caused primarily by the increase in the proportion of weather-sensitive demand, space heat, and air conditioning. The calculated growth rates are consistent with a drop in the annual load factor. The system peak demand grows at an annual average of $3.1 \%$ per year between 1980 and 2000, while energy demand grows at $2.8 \%$ per year.

The changes between 1980 and 2000 in the South Central Region are similar to those in the North Central. Region. The seasonal load factors generally decrease, and the annual load factor decreases from .52 to .47 , a decrease of about five percentage points. However, unlike the North Central Region, the South Central Region remains strongly summer peaking. The growth rate in peak demand is again larger than the energy growth rate, and both are larger than the corresponding quantities in the North Central Region.

\section{SENSITIVITY ANALYSIS}

To determine the relative effects of changes in the base case assumptions, we performed an extensive sensitivity analysis. The sensitivities involve changes in growth rates, technology penetration rates, efficiencies, and model parameters such as peak-to-normal day ratios. Changes that involve load management, customer storage, and time-of-use pricing were considered in a second series of sensitivities (reported later in this section). 
Definition of Sensitivity Cases

Following is a representative list of all the sensitivity cases. Differences, if any, between the North Central and South Central regions are indicated. The results are summarized in Tables 3-5 and 3-6, with details in Appendix F. These cases were designed to test the importance of uncertainties in data and growth rates. They reflect the concerns of people associated with the project. The results are summarized following the case descriptions.

Case 1: High Industrial Growth Rate

Rate of growth of industrial energy demand is approximately twice the base case value ( $4.3 \%$ versus $2.2 \%$ in North Central, $5.5 \%$ versus $2.8 \%$ in South Central).

Case 2: High Commericial Growth Ratc

Rate of growth of the commercial sector is 1.5 ilmes llie base case $(3.7 \%$ versus $2.5 \%$ in North Central, $4.7 \%$ versus $3.1 \%$ in South Central).

Case 3: Bruader Peak on Residential and Commercial Air Conditioning The load shapes of commercial and residential central air conditioning are assumed to be about three hours wider around a peak at about $3 \mathrm{p.m}$. This case is designed to test the sensitivity of system loads to the air conditioning load shape.

Case 4: . High Peak-to-Normal Day Energy Ratio for Residential and Commercial Space Heal

'l'he peak-to-normal latio for spoce heat is increased by $20 \%$ from 1.4 to 1.7 in both the residential and commercial sectors, (The change was from 1.71 to 2.05 in South Central.) This ratio measures the amount of space heat energy demanded on a peak day relative to a normal day. A ratio of 1.4 implies that the demand for space heat energy on a peak day is 1.4 times that of a normal winter day. The coldest $10 \%$ of all winter days are called "peak."

Case 5: High Peak-to-Normal Day Ratio on Residential and Commercial Air Conditioning

Peak-to-normal ratios in both the residential and commercial sectors are assumed to be $20 \%$ larger than the base case ( 2.4 versus 2.0 in North Central, 1.75 versus 1.46 in South Central). 
Table 3-5

SENSITIVITY ANALYSIS - RESULTS

NORTH CENTRAL REGION (YEAR 2000)

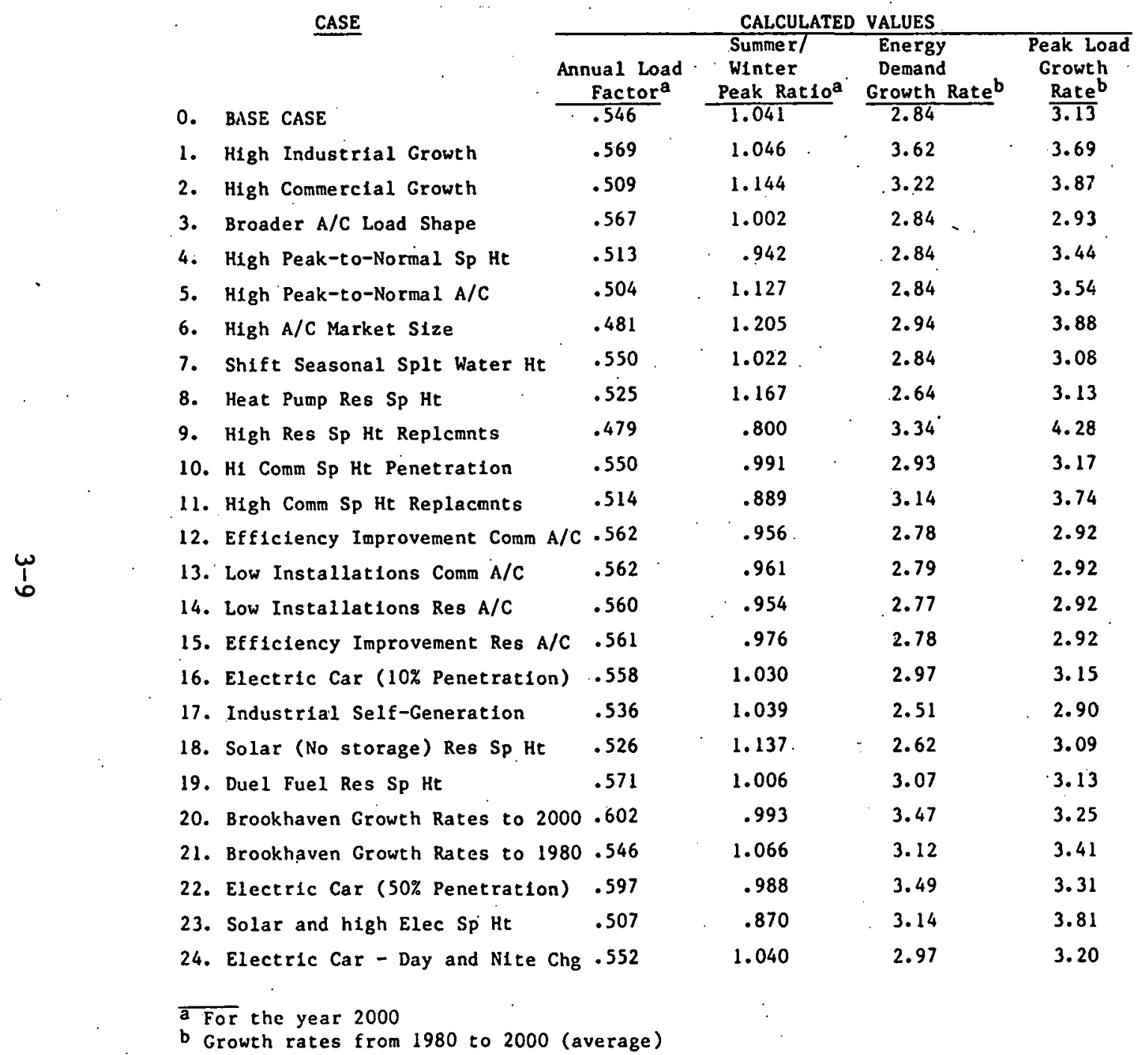

\begin{tabular}{|c|c|c|c|c|c|}
\hline & & \\
\hline $\begin{array}{c}\text { Annua: Load } \\
\text { Factor }^{\mathbf{a}}\end{array}$ & $\begin{array}{r}\text { Sumn } \\
\text { Wint } \\
\text { Peak } \\
\end{array}$ & $\begin{array}{l}\text { er } / \\
\text { er } \\
\text { Ratioa }\end{array}$ & $\begin{array}{r}\text { Energ } \\
\text { Deman } \\
\text { Growth } \\
\end{array}$ & $\begin{array}{l}\text { y } \\
\text { Rate } \\
\text { Rat }\end{array}$ & $\begin{array}{l}\text { Peak Load } \\
\text { Growth } \\
\text { Rate } \\
\end{array}$ \\
\hline 4.2 & 0.5 & & 27.5 & & .18 .1 \\
\hline-6.7 & 9.9 & & 13.4 & & 23.9 \\
\hline 3.8 & -3.8 & & 0.0 & & -6.3 \\
\hline-6.0 & -9.5 & & 0.0 & & 9.9 \\
\hline-7.7 & 8.3 & & 0.0 & & 13.2 \\
\hline-11.9 & 15.8 & & 3.7 & & 24.3 \\
\hline 0.8 & -1.8 & & 0.0 & & -1.3 \\
\hline-3.8 & 12.1 & & -7.0 & & 0.0 \\
\hline-12.1 & -23.2 & . & 17.7 & & 37.1 \\
\hline 0.8 & -4.8 & & 3.2 & & 1.5 \\
\hline-5.8 & -14.6 & & 10.7 & & 19.5 \\
\hline 3.0 . & -8.1 & & -1.9 & & -6.6 \\
\hline 3.1 & -7.7 & & -1.8 & & -6.6 \\
\hline 2.6 & -8.3 & & -2.4 & & -6.6 \\
\hline 2.8 & -6.2 & & -2.1 & & -6.6 \\
\hline 2.3 & -1.1 & & 4.8 & & 0.8 \\
\hline-1.9 & -0.2 & & -11.5 & & -7.4 \\
\hline-3.5 & 9.3 & & -7.7 & & -1.3 \\
\hline 4.7 & -3.3 & . & 8. $1^{11}$ & & 0.0 \\
\hline 10.3 & -4.6 & & 22.2 & & 4.0 \\
\hline 0.1 & 2.4 & & 10.0 & & 9.0 \\
\hline 9.4 & -5.1 & & 23.0 & & 6.0 \\
\hline-7.1 & -16.4 & & 10.6 & & 21.7 \\
\hline 1.1 & -0.1 & & 4.8 & & 2.4 \\
\hline
\end{tabular}

b Growth rates from 1980 to 2000 (average) 
Table 3-6

SENSITIVITY ANALYSIS RESULTS

SOUTH CENTRAL REGION (YEAR 2000)

CASE

o. BASE CASE

1. High Industrial Growth

2. High CommercialijGrowth

3. Broader A/C Load Shape

4. High Peak-to-Normal Sp Ht

5. High Peak-to-Normal A/C

6. High A/C Market Size

7. Shift Seasonal Splt Water Ht

8. Heat Pump Res Sp Ht

9. High Res Sp Ht Replcmnts

10. Hi Comm Sp Ht Penetration

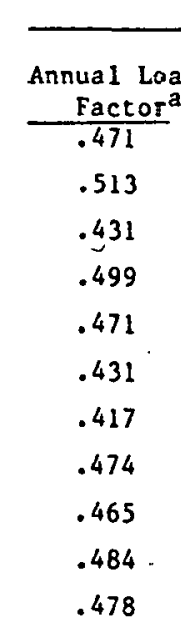

h Comm Sp Ht Replacmnts .490

12. Efficiency Improvement Comm A/C .508

13. Low Installations Comm $\mathrm{A} / \mathrm{C} \quad .513$

14. Low Installations Res A/C .491

15. Efficlency Improvement Res A/C .493

16. Electric Car ( $10 \%$ Penetration) .479

17. Industrial Self-Generation .456

18. Solar (No storage) Res Sp Ht .463

19. Duel Fuel Res Sp ht

.476

20. Brookhaven Growth Rates to $2000 \quad .552$

21. Brookhaven Growth Rates to $1980 \quad .485$

22. Electric Car ( $50 \%$ Penetration) .509

23. Solar and high Elec Sp Ht .476

24. Electric Car - Day and Nite Chg .476

a For the year 2000
$b$ Growth rates from 1980 to 2000 (average)

Growth rates from 1980 to 2000 (average)
CALCULATED VALUES

Summerl Energy

Growth

1.425

1.370

1.605

1.345

1.323

1.561

1.682

1.399

1.526

1.246

1.321

1.157

1.292

1.274

1.347

1. 331 .

1.4:0

1.446

1.551

1.420

1.272

1.412

1.355

1.340

1.419

$\frac{\text { Growth }}{3.12}$

4.38 .

3.67

3.12

3.12

3.12

3.34

3.12

3.04

3.26

3.19

3.32

3.00

2.98

3.04

3.00

3.22

2.70

3.00

3.16

4.11

3.73

3.60

3.14

3.22

3.68
4.50

4.68

3.38

3.68

4.15

4.54

3.64

3.68

3.68

3.68

3.68

3.17

3.10

3.39

3.32

3.69

3.42

3.64

3.68

3.84

4.15

3.76

3.64

3.72
PERCENT

Annial Load
Factor
--

Sumrie

Energy Demand

Peak Load

$--$

$\frac{\text { Peak Rat1o }}{--}$ Growth. Rate

Rate

$-3.8$

12.7

$-5.6$

$-7.2=$

40.4

17.5

22.5

6.0

0.0

$-8.5$

$-11.5$

0.7

$-1.4$

2.8

1.5

4.0

7.7

9.0

4.3

4.6

1.7

$-3.1$

$-1.8$

1.0

17.3

2.9

\&. 0

1.1

1.1

9.6

0.0

27.4

0.0

18.12

$\begin{array}{lll}-1.8 & 0.0 & -0.9\end{array}$

$\begin{array}{lll}7.1 & -2.5 & 0.0\end{array}$

$-12.5$

-6.5 .

$-16.0$

$-9.3$

$-10.6$

$-5.5 \cdot$

$-6.6$

$-1.0$

1.5

8.9

$-0.3$

$-10.7$

$-0.5$

$-4.9$

5.9

4.6

2.4

0.0

c. 0

$6.3 \quad 0.0$

$-3.8-13.8$

$-4.4-15.8$

$-2.5 \quad-7.9$

$-3.8 \quad-9.6$

$3.2 \quad 0.4$

$-13.4 \quad-6.9$

$-4.0 \quad-0.9$

$1.5 \quad 0.0$

$31.8-4.6$

$19.6{ }^{-} 12.9$

$15.3 \quad 2.2$

$-0.4$

$-0.9$

$\begin{array}{lr}0.7 & -0.9 \\ 3.2 & 1.3\end{array}$ 
Sase 6: High Original Market Size for Commercial Air Conditioning Original market size of commercial air conditioning is 1.5 times base case ( 460 versus $307 \times 10^{12} \mathrm{Btu} / \mathrm{yr}$ in North Central, 669 versus 464 in South Central).

Case 7: Shift of Seasonal Allocation of Energy in Residential Water Heat

Base case assumption is that water heat use is the same per day regardless of season. This gives a seasonal energy split directly proportional to the number of days in the season $(.25, .33$, and .42 for winter, summer, and fall/spring). The sensitivity case assumes a larger winter and smaller summer. share (.35 to .23 to .42$)$. Water input to heaters tends to be several degrees colder in winter months.

Case 8: Heat Pumps in Place of Resistance Space Heaters for New Residential Installations

New installations of electric space heat in the residential sector are assumed to be heat pumps rather than resistance. New residential space heat installations are $50 \%$ heat pump and $50 \%$ gas/oil rather than $50 \%$ electric resistance and $50 \%$ gas/oil as in the base case. Heat pump efficiencies are about $50 \%$ higher than resistance heating.

Case 9: High Replacement Share for Electric Resistance Space Heat in Residential Sector

Twenty percent of replacements of gas/oil furnaces in the residential sector are converted to electric resistance. Base case assumed no electric conversions.

Case 10: High Electric Resistance Penetration in Commercial Space Heat

The share of electric resistance in new commercial space heat installations is increased from the base case ( $20 \%$ versus $6 \%$ ). All other installations are assumed to be gas/o1l.

Case 11: High Replacement Share for Electric Resistance Space Heat in the Commercial Sector

Twenty percent of replacements of gas/oil furnaces in the commercial sector are by electric resistance. Base case assumed no electric replacements. 
Case 12: Efficiency Improvement in Commercial Air Conditioning

Efficiency of commercial air conditioning is improved by $30 \%$ (from 3.0 to 3.9 ). No improvement was assumed in the base case.

Case 13: Low New Installation Share for Commercial Air Conditioning Installation share of air conditioning in the commercial sector reduced ( $50 \%$ versus $90 \%)$. The remainder is assumed not to have air-conditioning. The $50 \%$ corresponds to airconditioning saturations in the existing building stock.

Case 14: Low Installation Rate of Residential Air Conditioning Installation chare of no appliance, central a/c, and room a/c is assumed to be the same as the 1972 distribution $(.65, .12$, and .23, respectively, in the North Central, rather than the base case values . 2, .6, and .2; in South Central .38, .24, and .38 versus $.2, .6$, and .2 ).

Case 15: Efficiency Improvement in Residential Air Conditioning

Efficiency of residential air conditloners is improved by $30 \%$ ( 2.5 to 3.3 for central $\mathrm{a} / \mathrm{c}$ and 2.0 to 2.6 for room $\mathrm{a} / \mathrm{c}$. )

Case 16: Electric Car--Ten Percent Penetration

Ten percent of all vehicle miles driven in the year 2000 will be by electric car. The assumed load shape for the electric car is shown in Figure E-6.

Case 17: Increased Industrial Self-Generation

The total industrial energy demand is assumed to be reduced by $20 \%$ from the base case.

Case 18: High Solar Penetration in Residential Space and Water Heat

Solar space and water heating systems with nonstorable electric backup are installed in half of the new housing that otherwise (base case) would install electric resistance. In other words, installation shares are assumed to be $50 \%$ gas/o11, $25 \%$ resistance, $25 \%$ solar rather than $50 \%$ gas/oil and $50 \%$ resistance. Solar systems are assumed to be sized to provide $50 \%$ of space heat and $90 \%$ of water heat requirements [16]. The remainder is electric backup with standard space heat load shape. It is assumed that low solar insolation days are typically not peak cold days. 
Case 19: High Replacements by Dual-fueled (Bivalent) Heat Pump Systems in the Residential Sector

Twenty percent of replacements. of gas/oil furnaces are dual-fueled heat pump systems in the residential sector. These systems use both electricity and gas or oll. The gas/oil capability is used to backup the heat pump during high demand (cold) periods: One result is a high load factor on the electric demand.

Case 20: Brookhaven Growth Rates to 2000

North Central sector growth rates calculated from Reference [4] projections are as follows:

\begin{tabular}{|c|c|c|c|}
\hline & $\begin{array}{l}1972- \\
1980 \\
\end{array}$ & $\begin{array}{l}1981- \\
1985 \\
\end{array}$ & $\begin{array}{l}1986- \\
2000 \\
\end{array}$ \\
\hline Residential & 1.8 & 1.4 & 1.0 \\
\hline Commercial & 2.6 & 1.3 & 1.2 \\
\hline Industrial & 3.5 & 4.2 & 3.9 \\
\hline
\end{tabular}

South Central Brookhaven growth rates are as follows:

\begin{tabular}{|c|c|c|c|}
\hline & $\begin{array}{l}1972- \\
1980 \\
\end{array}$ & $\begin{array}{l}1981- \\
1985 \\
\end{array}$ & $\begin{array}{l}1986 \\
2000 \\
\end{array}$ \\
\hline Residential & 1.4 & 2.0 & 1.3 \\
\hline Commercial & 2.6 & 1.6 & 1.5 \\
\hline Industrial & 4.4 & 4.8 & 4.4 \\
\hline
\end{tabular}

The year intervals were made to correspond with those in Brookhaven. In general, these rates are lower than the base case for the commercial sector and higher in the industrial.

Case 21: Brookhaven Growth Rates to 1980

1972-1980 sector growth rates from Reference [4] were used to estimate 1980 energy allocations. This case was run to check sensitivity to 1980 energy allocations.

Case 22: Electric Car- $-50 \%$ Penetration

Installation share and replacement shares for automobiles are set at $50 \%$ gasoline and $50 \%$ electric.

Case 23: High Solar Penetration in Residential Space and Water Heat Combined with $20 \%$ Electric Resistance Replacements

Same as Case 18 , except with $20 \%$ replacements of gas/oil furnaces by electric resistance as in Case 9. 
Case 24: Electric Car--Day and Night Charging

As in Case 16, 10\% of all vehicle. miles are assumed to be driven in electric cars. However, the charging pattern is assumed to be perfectly flat throughout the day and night.

The results of the sensitivity analysis are discussed by topic: Only the highlights are mentioned, since a complete description of each case is contained in Appendix F. Comments will refer to the North Central Region unless specifically stated otherwise.

Growth Rates

The growth rate sensitivities are cases 1,2 , and 20 . High industrial growth (Case 1) causes an increase in the load factor from .55 to .57, about a $4 \%$ increase. On the other hand, high commercial growth (Case 2) causes a decrease in the load factor from .55 to .51, about a $7 \%$ decrease. Both cases cause increases in growth rates. However, Case 1 causes a greater Increase in energy demand growth, and Case 2 causes a greater increase in peak load growth.

Cases 20 and 21 involved using sector growth rates from Reference [4]. In Case 20, the growth rates are lower than the base case in the commercial sector and higher in the industrial sector. The result is an increase in the annual load factor from .55 to .60 . This is explained by the relative magnitude of load factors in the commercial and industrial sectors. The Industrial sector has an anmual luad factor of about 0.8 . The rnmmerrial sector load factor is much lower.

\section{Space Heat}

Sensitivity cases $4,8,9,10,11$, and 19 relate to space heat. The largest impacts are associated with Case 9, in which it is assumed that $20 \%$ of gas/oil furnace replacements are conversions to electric resistance. Under this case, the North Central Region becomes strongly winter peaking 
with a summer-to-winter peak ratio of .8. The annual load factor also drops, from .55 to .48. In contrast, in the South Central Region, the system remains summer peaking, and the annual load factor increases from .47 to .48. The other space heat sensitivities have little impact on the South Central Region, largely, because the region is so strongly summer peaking.

The heat pump cases are Cases 8 and 19. The introduction of a conventional heat pump with electric resistance backup causes a reduction in the annual load factor from .55 to .52. On the other hand, the dual-fueled (blvalenc) heat pump of Case 19 causes an increase in the load factor to .57 .

\section{Solar Heating}

Both cases involving solar heating systems with nonstorable electric backup (Cases 18 and 23) resulted in decreases in the annual load factor. However, the load factor in Case 23 is higher than that in Case 9. This result indicates that solar systems could improve the load factor of utilities that expect large shifts away from heating with gas or o1l.

\section{Air Conditioning}

Both the North Central and South Central regions are highly sensitive to changes in air conditioning (sensitivity cases 3, 5, 6, 12, 13, 14, and 15). The largest change in the annual load factor is caused by Case 6 , in which the original market size was assumed to be 1.5 times the Brookhaven estimate. This caused a reduction in the annual load factor from .55 to .48. On the other hand, Cases 12,13,14, and 15, which involve either efficlency improvements or lower market penetrations, resulted in increases in the load factor of about $3 \%$. These cases indicate the importance of improving our understanding of air-conditioning use in the commercial sector. 
Industrial Self-Generation

Case 17 reflects the potential impact of increased use of self-generation by industry. Assuming that $20 \%$ of the industrial load is removed from the power system, the annual load factor is reduced by about $2 \%$ (from .55 to .54). This reflects the fact that the load factor of industrial demands tends to be high.

\section{Electric Car}

Three cases address the potential impact of the electric car. All of them result in increases in the annual load factor because of the large amount of off-peak charging. In Case 16, in which $10 \%$ of all vehicle miles are assumed to be driven by electric cars in the year 2000 , the load factor increases slightly (from .55 to. .56).

\section{ANALYSIS OF LOAD MANAGEMENT}

To determine the potentlal effects of energy storage systems, time-of-use pricing, and other load management programs, several load management cases were run. This section describes the cases and summarizes the results.

\section{Definition of Load Management Cases}

Following is a list of the load management cases. The resulcs are summarized in Tables 3-7 and 3-8.

Case 1: Controls on All New and Replacement Residential Electric Hot Water Heaters

A11 new installations and replacements that would normally be conventional electric resistance are replaced by controlled electric resistance water heaters. The effect of the control is estimated using the load management (customer storage) algorithm.

Case 2: $\quad$ Energy Storage on Residential Electric Space Heat

All new installations of residential electric space heat have unlimited daily cycle heat storage capability. 
Table 3-7

LOAD MANAGEMENT ANALYSIS RESULTS NORTH CENTRAL REGION (YEAR 2000)

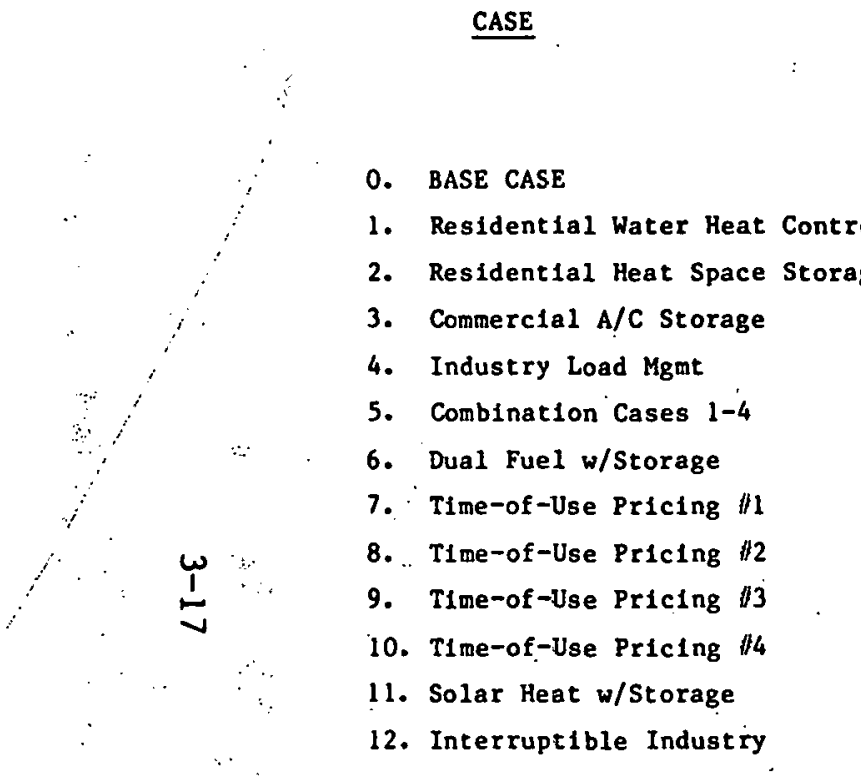

\begin{tabular}{|c|c|c|c|}
\hline \multicolumn{4}{|c|}{ CALCUSATED VALUES } \\
\hline $\begin{array}{l}\text { Annual Load } \\
\text { Factor }\end{array}$ & $\begin{array}{l}\text { Summer! } \\
\text { Winter } \\
\text { Peak Rar10 }\end{array}$ & $\begin{array}{l}\text { Energy } \\
\text { Demand } \\
\text { Growth Rate }\end{array}$ & $\begin{array}{l}\text { Peak Load } \\
\text { Growth } \\
\text { Rate }\end{array}$ \\
\hline .546 & 1.041 & 2.84 & 3.13 \\
\hline .558 & 1.032 & 2.84 & 3.01 \\
\hline .546 & 1.232 & 2.84 . & 3.13 \\
\hline .568 & .960 & 2.84 & 2.92 \\
\hline .574 & 1.021 & 2.84 & 2.86 \\
\hline .628 & 1.086 & 2.84 & 2.40 \\
\hline .571 & 1.040 & 3.07 & 3.13 \\
\hline .557 & 1.048 & 2.84 & 3.01 \\
\hline .591 & 1.032 & 2.84 & 2.72 \\
\hline .592 & 1.046 & 2.70 & 2.56 \\
\hline .601 & 1.039 & 2.69 & 2.48 \\
\hline .527 & 1.211 & 2.62 & 3.08 \\
\hline .581 & 1.000 & 2.84 & 2.80 \\
\hline
\end{tabular}

\begin{tabular}{|c|c|c|c|}
\hline \multicolumn{4}{|c|}{ PERCENT CHANGE FROM BASE CASE } \\
\hline $\begin{array}{l}\text { Annual Load } \\
\text { Factor }\end{array}$ & $\begin{array}{l}\text { Summer } \\
\text { Winter } \\
\text { Peak Rat1o } \\
\end{array}$ & $\begin{array}{c}\text { Energy } \\
\text { Demand } \\
\text { Growth Rate } \\
\end{array}$ & $\begin{array}{l}\text { Peak Load } \\
\text { Growth } \\
\text { Rate }^{\mathrm{b}}\end{array}$ \\
\hline-- & - & - & - \\
\hline 2.2 & -0.8 & 0.0 & -3.6 \\
\hline 0.1 & 18.4 & 0.0 & 0.0 \\
\hline 4.1 & -7.7 & 0.0 & $-6.6-$ \\
\hline 5.2 & -1.9 & 0.0 & -8.4 \\
\hline 15.1 & 4.3 & 0.0 & -23.3 \\
\hline 4.6 & -0.1 & 8.1 & 0.0 \\
\hline 2.1 & 0.6 & 0.0 & -3.6 \\
\hline 8.3 & -0.9 & 0.0 & -13.0 \\
\hline 8.5 & 0.5 & -5.0 & -18.2 \\
\hline 10.2 & -0.2 & -5.1 & -20.6 \\
\hline-3.5 & 16.3 & -7.7 & -1.4 \\
\hline 6.5 & -3.9 & 0.0 & -10.4 \\
\hline
\end{tabular}

a For the year 2000

b Growth rates from 1980 to 2000 (annual average) 
Table 3-8

LOAD MANAGEMENT ANALYSIS RESULTS

SOUTH CENTKAL REGION (YEAR 2000)

CASE

Rate $^{\text {b }}$

1. Restdential Water Heat Control

2. Residential Space Heat Storage

3. Commercial A/C Storage

4. Industry Load Mgmt

5. Combination Cases 1-4

6. Dual Fuel w/Stcrage

7. Time-of-Use Pricing $\| 1$

8. Time-of-Use Pricing $\$ 2$

9. Time-of-Use Pricing 3

10. Time-of-Use Pricing 14

11. Solar Heat w/Storage

12. Interruptible Industry
0. BASE 'CASE

\begin{tabular}{|c|c|}
\hline $\begin{array}{l}\text { Annua: Load } \\
\text { Factor }\end{array}$ & $\begin{array}{r}\text { Summer } \\
\text { WInter } \\
\text { Peak Ra }\end{array}$ \\
\hline $.47:$ & 1.425 \\
\hline .480 & 1.414 \\
\hline .473 & 1.571 \\
\hline .524 & 1.282 \\
\hline $.49: 3$ & 1.395 \\
\hline .558 & 1.368 \\
\hline .475 & 1.430 \\
\hline .481 & 1.442 \\
\hline .512 & 1.395 \\
\hline $.52 \%$ & 1.365 \\
\hline $.53 ?$ & 1.351 \\
\hline .46 .3 & 1.588 \\
\hline .507 & 1.330 \\
\hline
\end{tabular}

a For the year 2000

b Growth rates frod 1980 to 2000 (annual average)
PERCENT CHANGE FROM BASE CASE

\begin{tabular}{|c|c|c|c|}
\hline $\begin{array}{l}\text { Inrual Loa } \\
\text { Factor }\end{array}$ & $\begin{array}{c}\text { Summer } \\
\text { W1nter } \\
\text { Peak Rat:10a }\end{array}$ & $\begin{array}{c}\text { Energy } \\
\text { Demand } \\
\text { Growth Rate }\end{array}$ & $\begin{array}{l}\text { Peak Load } \\
\text { Growth }\end{array}$ \\
\hline
\end{tabular}

Growth

Demand Growt Factor $^{a}$

Peak Rat10 ${ }^{a}$ Growth Rate

$-$

2.0

$-0.7$

$+$

3.58

3.68

3.13

3.39

2.81

3.68

3.57

3.25

3.13

3.04

3.64

3.32

\section{1}

11.2

5.8

18.4

c:9.

2.1

8.7

10.8

12.9

$-1.6$

7.1
10.3

$-10.0$

$-2.1$

$-4.0$

0.4

1.2

$-2.1$

$-4.2$

$-5.2$

11.5

$-6.6$
$-$

$-2.6$

0.0

$-1.4 .8$

$-7.8$

$-23.7$

0.0

$-3.0$

$-11.7$

$-14.9$

$-17.4$

$-1.0$

$-9.6$ 

Case 3: Energy Storage on Commercial Air Conditioning
One-half of all new installations of commercial air. conditioning have unlimited cool storage capability.
Case 4: Management of 25\% of Industrial Energy Use
Twenty-five percent of the industrial energy load is redistributed by the load management model in a fashion that flattens daily system load shapes as much as possible.
Case 5: Combination of Residential, Commercial, and Industrial Load Management
This is a combination of all load management activities of Cases 1 through 4 .

Case 6: Energy Storage on Dual-fueled Residential Space Heat

The dua1-fueled heating systems of Case 19 (Appendix F) are assumed to have daily cycle energy storage capability.

Case 7: Time-of-Use Pricing \#1 (See Section 2 and Appendix D for elasticity definitions.)

All end uses and technologies are assumed to have an hourly price elasticity of approximately .1 and energy price elasticity of zero.

Case 8: Time-of-Use Pricing 非

All end uses and technologles are assurwed to have an hourly price elasticity of .5 and energy price elasticity of zero.

Case 9: Time-of-Use Pricing 非

All end uses and technologies are assumed to have an hourly price elasticity of .1 and an energy price elasticity of .5 .

Case 10: Time-of-Use Pricing \#4

All end uses and technologies are assumed to have an energy elasticity of .5. Hourly elasticities are assumed to be as follows :

$\begin{array}{ll}\text { Residential } & .1 \\ \text { Commercial } & .2 \\ \text { Industrial } & .3\end{array}$

Case 11: Solar Systems with Energy Storage

The electric backup of the solar heating system described in Sensitivity Case 18 has an energy storage capability. 
Case 12: Interruptible Service on 25\% of Industrial Load

Up to $25 \%$ of the Industrial demand can be interrupted up to four hours on etther peak summer or peak winter days.

\section{Energy Storage Systems}

Cases $1,2,3,6$, and 11 involve analysis of various kinds of energy storage or controlled systems at the customer's site. Hot water heater control results in an increase of the annual load factor of about one percentage point (from .55 to .56 in the North Central Region and from .47 to .48 in the South Central Region). The impact of hot water heater control on system load shapes is shown in Figure 3-1.

Energy storage systems used in conjunction with residential space heat do not significantly increase annual load factors in either the North Central or South Central regions, so long as the regions are dominantly summer peaking. However, it is clear that residential space heat storage can greatly reduce the winter peak and increase the seasonal load factor. Therefore, one would expect a considerable increase in the load factor if space heat storage were applied to a strongly winter peaking system.

Commercial air-conditioning storage has a large effect, especially in the South Central Region, where the annual load factor was increased by five. percentage points (from .47 to .52 ).

Adding storage on the electrical component of the dual-fueled space heating case almost doubled the increase in seasonal load factors and the impact on Interseasonal peaking patterns. (Compare the Base Case with Case 19, Table F-21, and Load Management Case 6, Table G-6.) The economic impact of these changes depends heavily on whether the system is initially summer or winter peaking.

Adding storage to the electrical backup component of the solar space heat case increases the winter season load factor by about four percentage points and reduces the winter peak by 6 percent. Thus, substantial frac- 

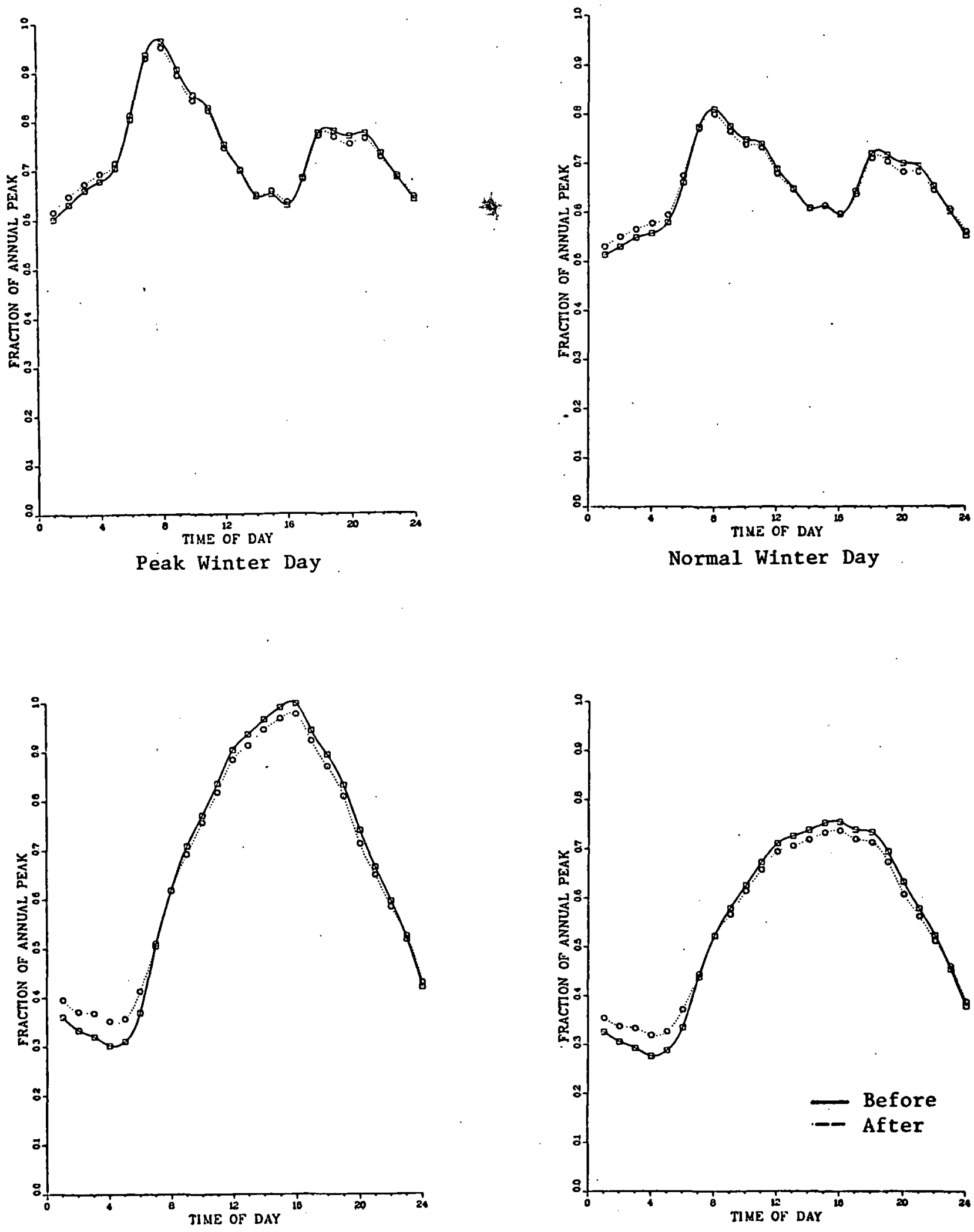

Peak Summer Day

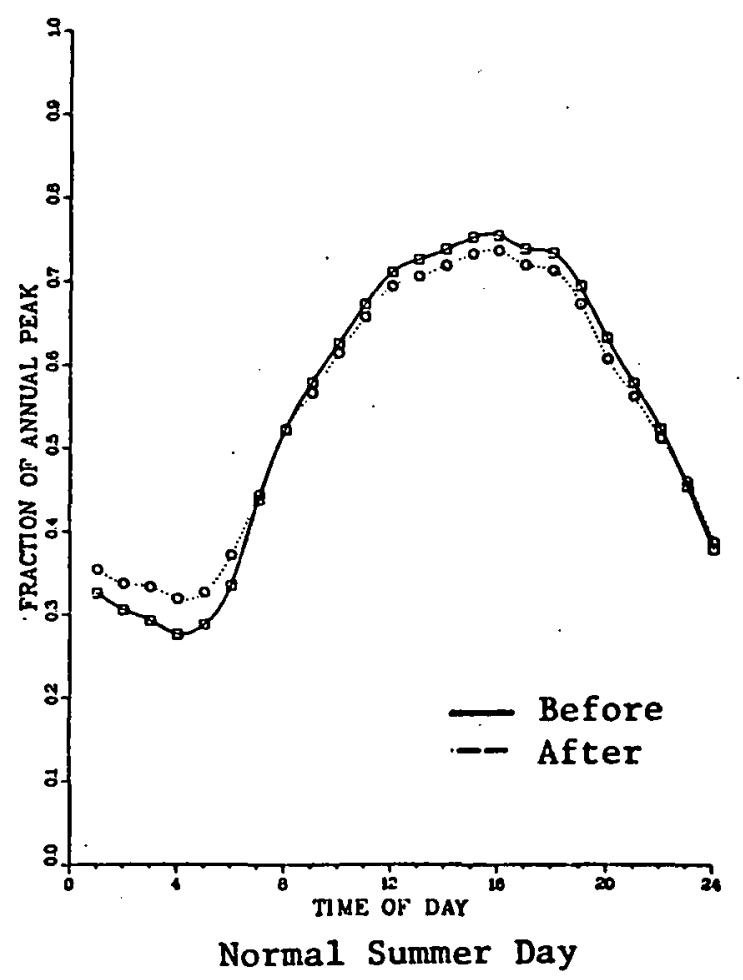

Figure 3-1. Results of Load Management Case 1, North Central Region, Year 2000.

Residential Hot Water Heat Control (100\% of new and replacement units). 
tions of solar assisted space heat together with thermal storage capacity could lead to higher winter load factors together with less electricity consumption. (Compare the Base Case with Case 18, Table F-20, and Load Management Case 11, Table G-11.)

\section{Industrial Load Management}

The industrial load management cases (Cases 4 and 12) both resulted in significant increases in annual load factors. In the North Central Region, these increases were larger than the increases of any energy storage case. In the South Central Region, only the commercial air conditioning storage case resulted in a larger increase in the annual load factor.

\section{Combination of Load Management Cases}

Caoe 5 includes hot water heater contol, residential electric space heat storage, commercial air-conditioning storage, and load management of $25 \%$ of the industrial load. The impact on the North Central system load shapes is shown in Figure 3-2. The 1mpact on the corresponding annual load duration curves is displayed in Figure 3-3. The annual load factor in the North Central Region is increased from .55 to .63 , a $15 \%$ increase.

\section{Time-of-Use Pricing}

There is a broad consensus that little is known about the magnitude of electric demand elasticities, either the energy elasticity or the hourly elasticities (elasticities of substitution among time periods). The values chosen for Sensitivity Cases 7 through 10 would probably be considered quite high by most researchers $[10,11]$. However, these high values are consistent with our objective of establishing upper limits on time-of-use price impacts.

A peak-to-valley price ratio of $3: 1$ was used to simulate time-of-use pricing. This ratio was chosen to reflect the marginal cost differential between oil (a peaking fuel) and coal (a baseload fuel). The algorithm relating price and demand level is illustrated in Figure 2-8. For illustra- 


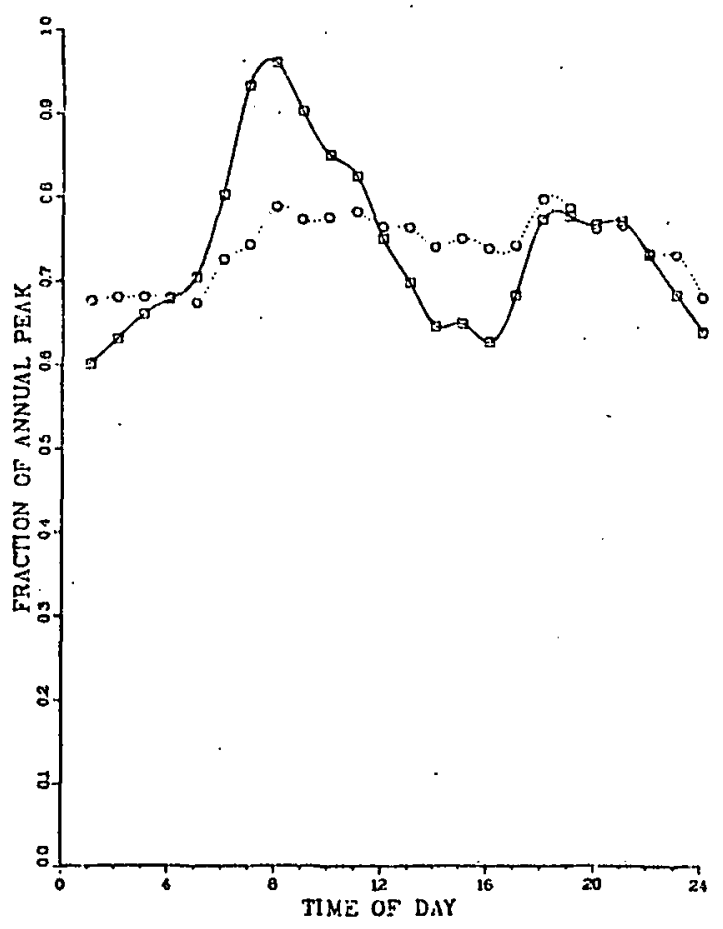

Peak Winter Day

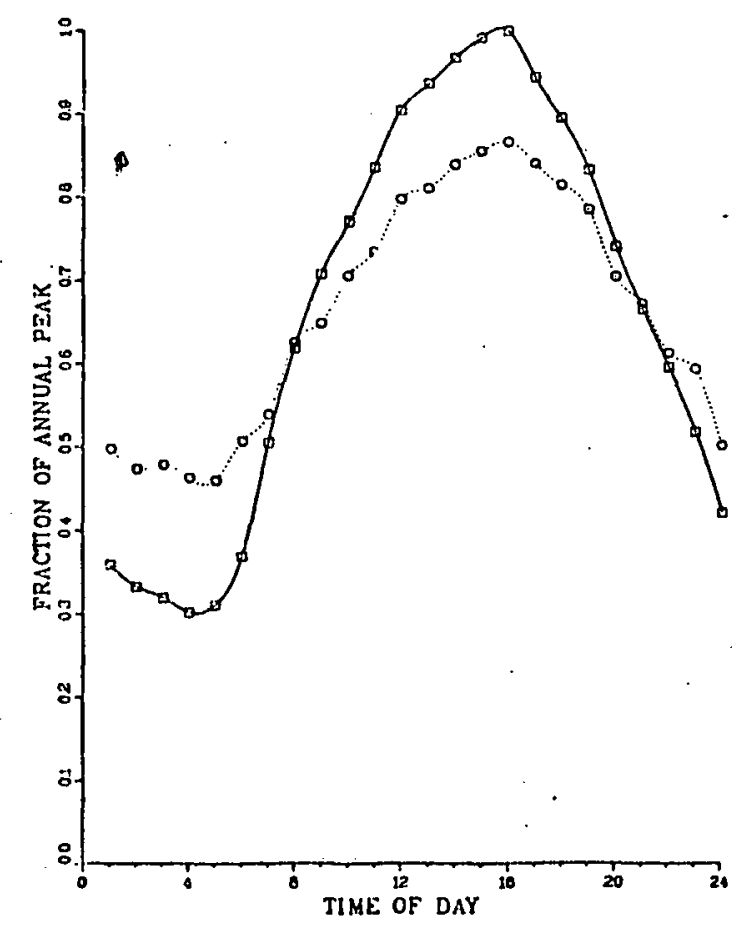

Peak Summer Day

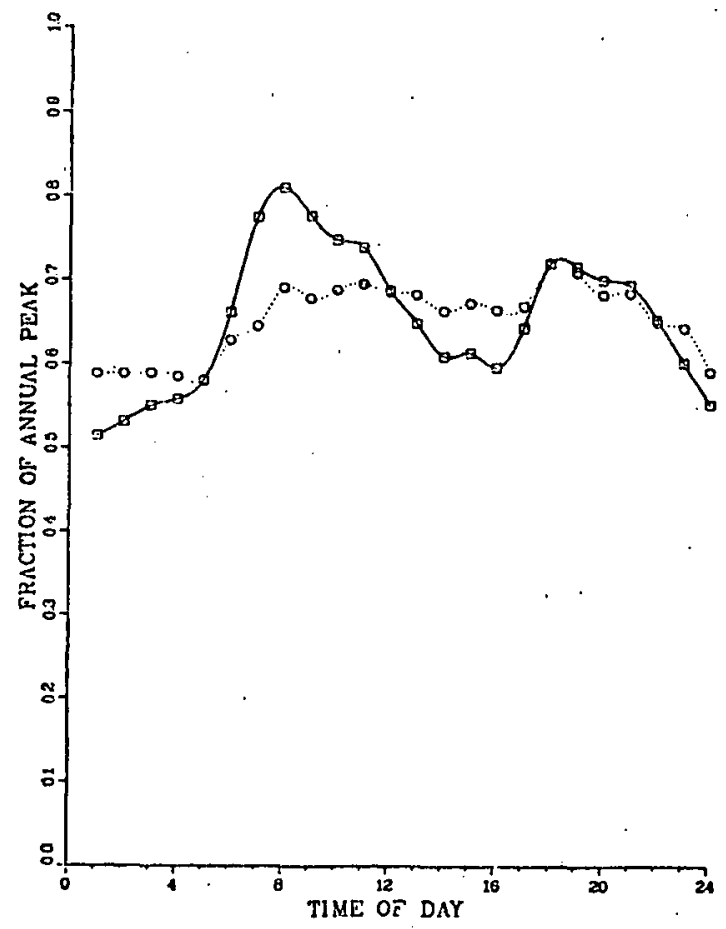

Norma1 Winter Day

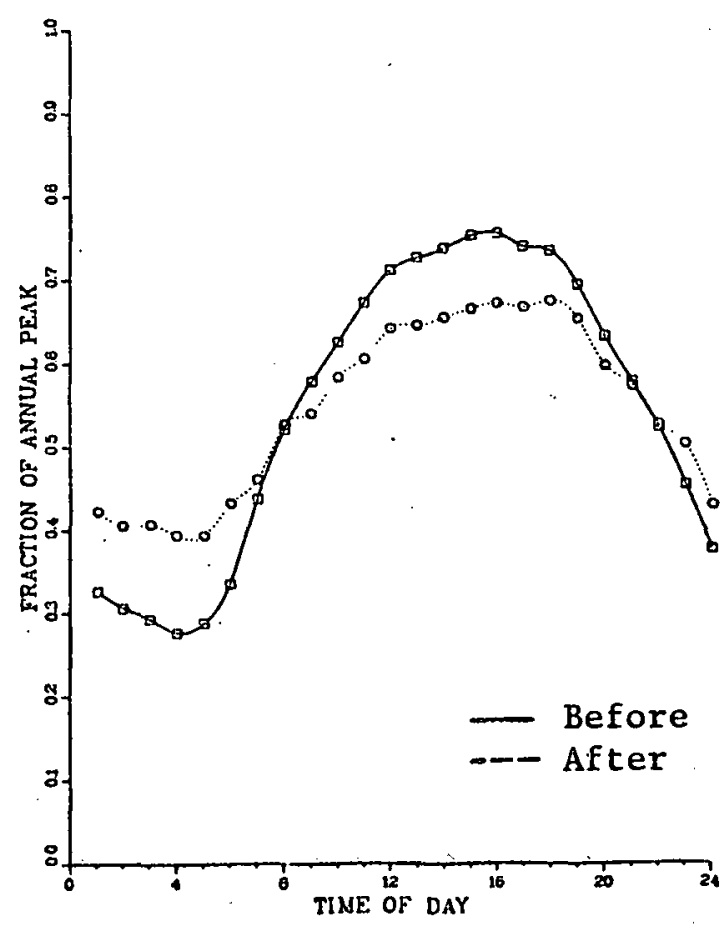

Normal Summer Day

Figure 3-2: Results of Load Management Case 5, North Centra1 Region, Year 2000.

Residential Hot Water Heat Control (100\% of new and replacement units)

Residential Space Heat Storage ( $100 \%$ of new units)

Commercial Air-Conditioning Storage (50\% of new units)

Industrial Load Management (25\% of Industrial load) 


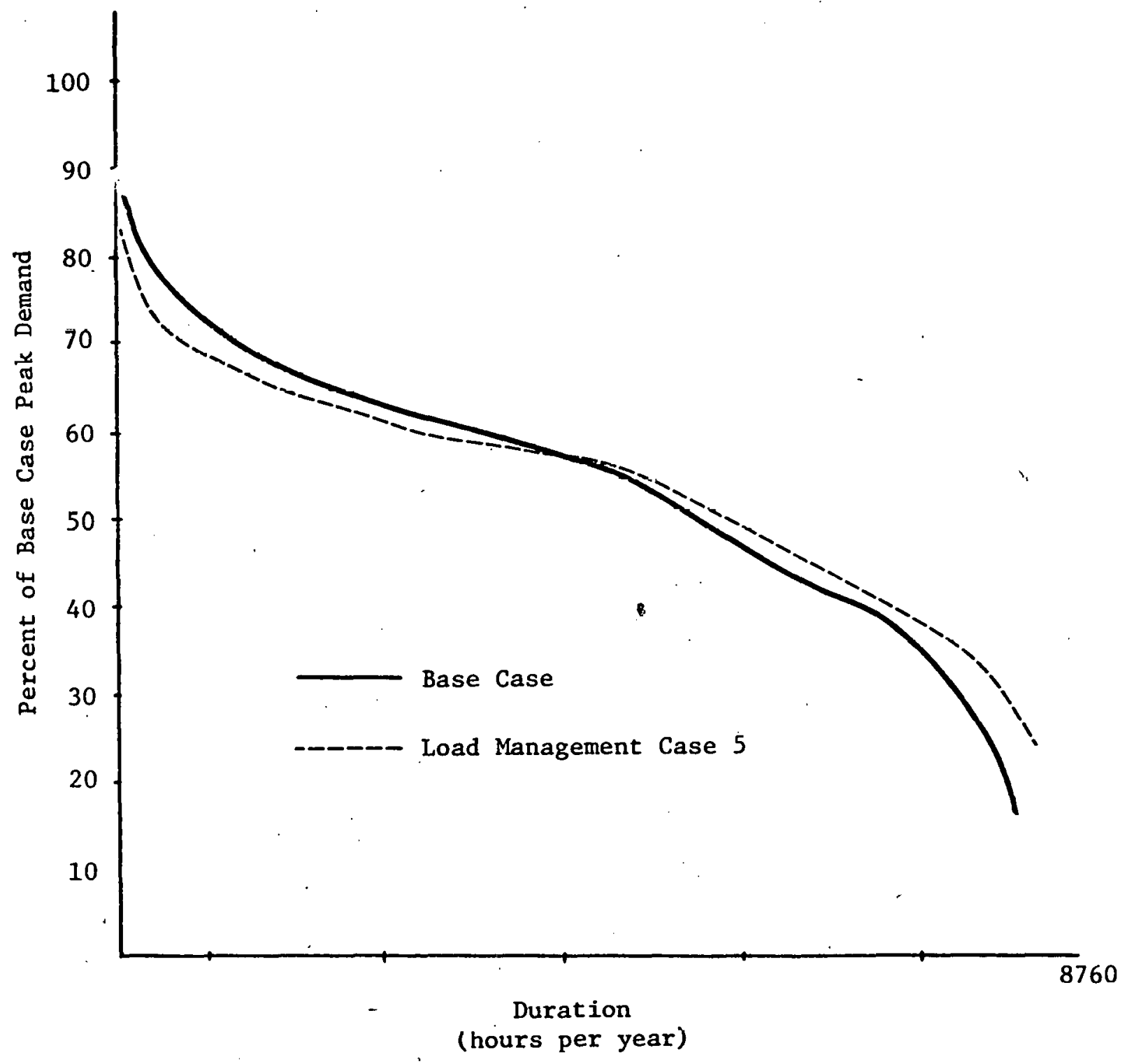

Figure 3-3. Annual Load Duration Curves for Base Case and Load Management Case 5 (North Central Region). 

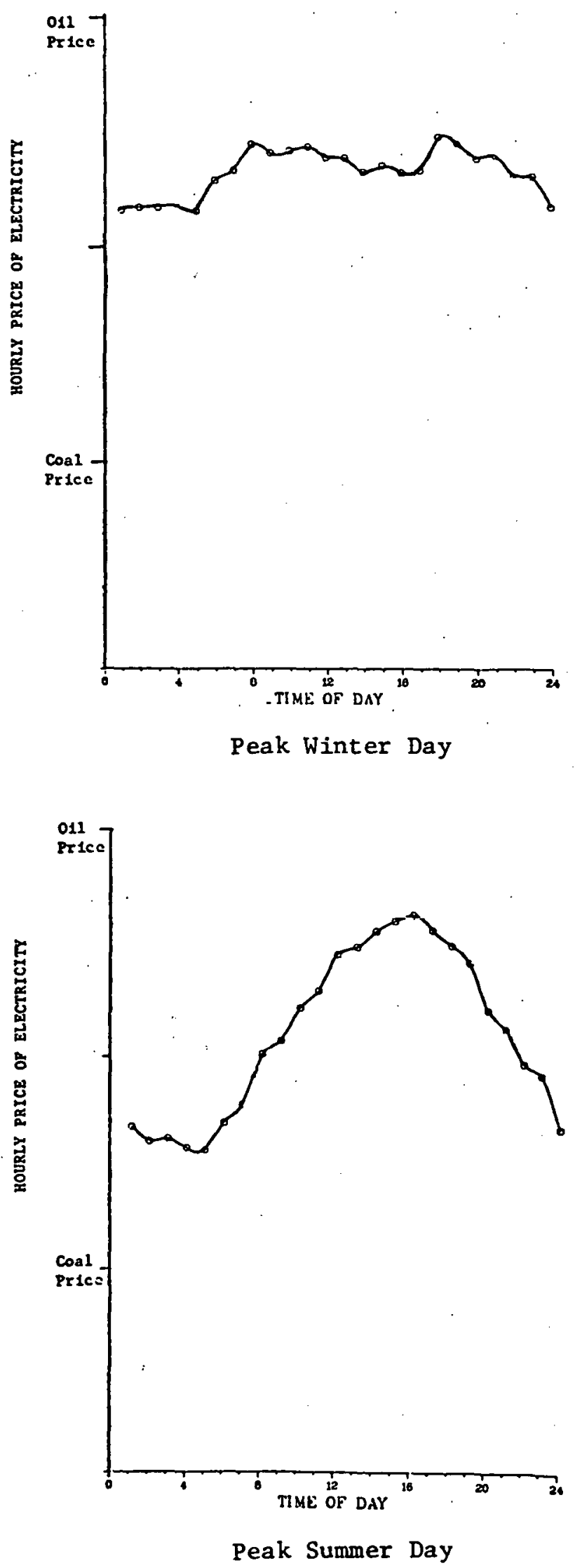

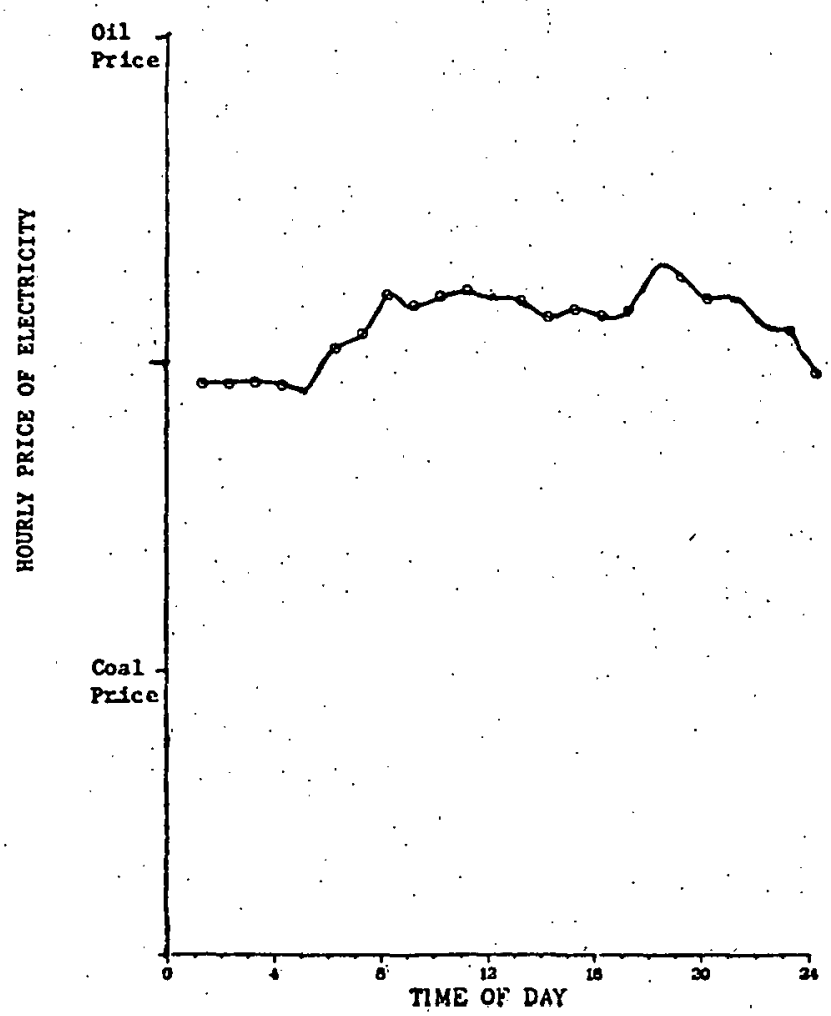

Normal Winter Day

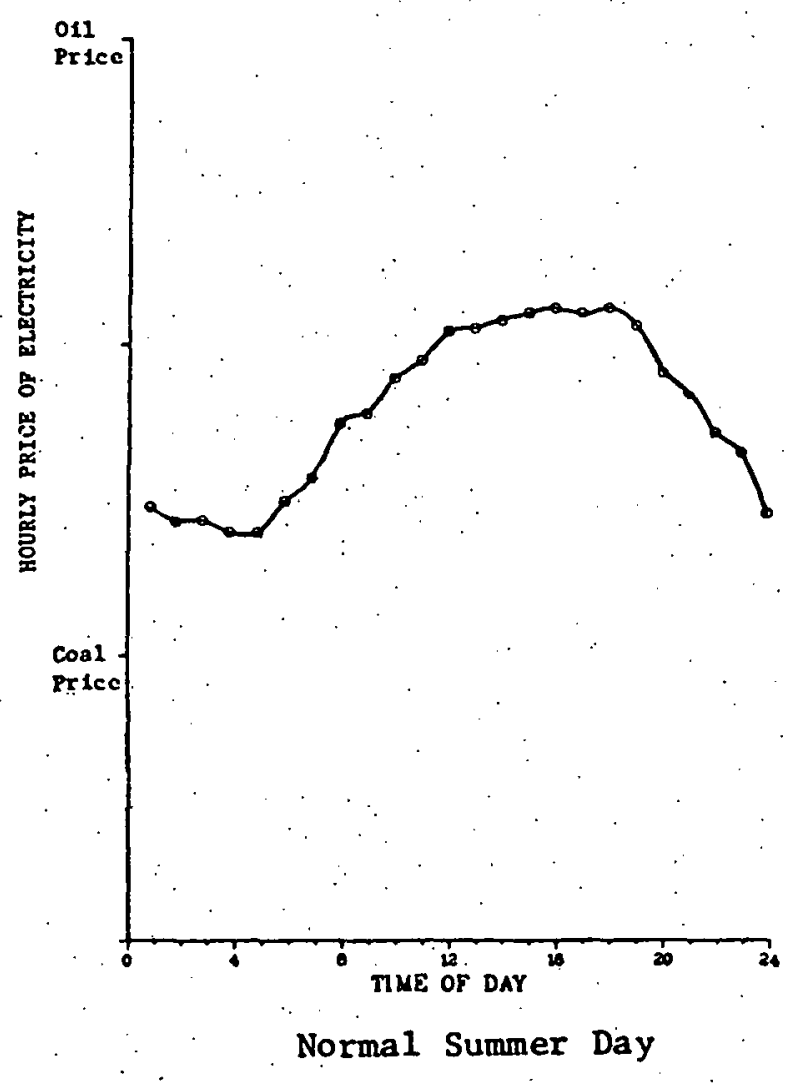

Figure 3-4. Hourly Time-of-Use Prices Corresponding to Load Management. Case 5, North Central Region, Year 2000.

3-25 
tion, the price structure corresponding to the demands in Figure $3-2$ is shown in Figure 3-4.

The results of the time-of-use price sensitivities provide some interesting insights. First, a comparison of Cases 7 and 8 indicates that apparently a change in energy elasticity from 0 to .5 has the same impact on load factors as does changing the hourly (cross-period substitution) elasticity from 0 to .5. The major difference is that in Case 7 there is a signif1cant change in the energy growth rate along with the change in load factors. This result points out the importance of understanding whether the dominant effect of time-of-use pricing will be to cause customers to use less energy or use the same amount but at different times of the day.

Case 10 reflects a high electric energy elasticity (.5) together with hourly elasticities of $.1, .2$, and .3 for the residential, commercial, and industrial sectors, respectively. These elasticities, together with the assumed price structure, result in an increase in the annual load factor of from .55 to .60 . This is about two-thirds of the effect of the intensive load management case (Case 5). This comparison supports the conclusion that the key to understanding the impact of time-of-day pricing is understanding the potential for industrial load management and understanding when and where consumer-owned energy storage technologies will be deployed.

\section{Interruptible Industrial Loads}

The peak day interruption capability raises annual load factors by about $3 \%$ in both northern and southern regions. This is comparable to the impact of managing $25 \%$ of the industrial energy demand on a dally basis throughout the year. The important difference in the results is that load management raises all dally, weekly, and seasonal load factors as well as the annual load factor. 


\section{SUMMARY}

The sensitivity cases discussed in this section seem to indicate that daily, weekly, and seasonal demand patterns in the year 2000 will exhibit a fair amount of variation and that they may be quite similar to today's patterns. The most drastic change might be a strong shift to winter peaking in the Northern United States, caused by Increasing use of electric space heat (with or without storage). The South Central Region will remain summer peaking even with very high electric space heat penetrations.

It is also apparent from the sensitivity cases that although load management might cause increases, in annual load factors of 5-10\%, it would be very surprising to see annual load factors exceed $80 \%$ in the year 2000 . 


\section{THIS PAGE \\ WAS INTENTIONALLY LEFT BLANK}

$$
3.28
$$


Section 4

ASSESSMENT OF THE NEED FOR PEAKING AND INTERMEDIATE

TECHNOLOGIES IN THE YEAR 2000

The purpose of the analysis described in this section is to examine the results of previous sections and to assess the extent that peaking- and Intermediate-duty generation technologies will be needed in the year 2000 . This need is assessed in the following two ways:

1. Examination of the annual load duration curves associated with the sensitivity cases described in Section 3.

2. Determination of the optimal mix of generation capacity required to serve the demand patterns of Section 3. The electric power. system capacity expansion and operation model described in Section 2 is used to make this determination.

We also use the electric power system model to assess an upper limit on the deployment of utility-owned energy storage technologies as a means of displacing expensive liquid fuels with coal and uranium. The upper limit was estimated by assuming that the only costs associated with storage are due to efficiency losses. Although storage capacity will obviously not be free, this exercise provides useful insights into the limitations of storage and the potential role of low-capital-cost peaking alternatives, such as combustion turbines or interruptible service, in the presence of storage alternatives.

It is apparent from the analysis that follows that with high probability there will be a continuing need for generation or storage technologies that are technically and economically suited to operate with capacity factors of less than $30 \%$. These results were obtained under a broad range of demand growth and load management and time-of-day price scenarios. 
ANNUAL LOAD DURATION CURVE RESULTS

Intermediate and peaking technologies (IPTs) are generally regarded as those electric power generation methods that have relatively low capital costs but high. operating costs. The dominant IPTs in current use are gas and oil-fired combustion turbines or steam boilers designed for short duration, intermittent service. Historically, these technologies have been the most economic means of serving demands of less than about 2000 hours per year. The 2000 hours figure corresponds to capacity factors of about $25 \%$.

The load duration data associated with the 12 load management cases of Section 3 are summarized in Tables 4-1 and 4-2 for the North Central and South Central regions, respectively. The results indicate that the IPT portion of demand (the portion with a capacity factor of less than $30 \%$ ) constitutes 30 to $40 \%$ of peak demand in the North Central Region and 38 to $46 \%$ in the South Central Region. The method used to estimate load duration probably overstates the absolute size of these fractions. The significant fact, however, is that the fractions are quite large (they are comparable to today's demands) and that the extreme load management (Case 5) and time-of-use pricing response (Case 10) simulations decrease the fractions by $16 \%$ but in no way eliminate them. This leads to the conclusion that although the need for IPTs in the year 2000 will probably be less than it is today, it will continue to be substantial.

SYSTEM OPTIMIZATION RESULTE

The preceding line of reasoning ignores economics and the role of IPIs in providing reliability. (Installed capacity typically exceeds peak annual demand by $20 \%$ to maintain a desired level of system reliability.) A first cut at including this aspect was made by using a generation system optimizing model that accounts for the cost of new plants, fuel costs, efficiencles, outage rates, maintenance requirements, and reserve margin constraints. The model is described in Appendix $C$. 
Table 4-1

RESULTS OF CAPACITY FACTOR ANALYSIS NORTH CENTRAL REGION (YEAR 2000) CUMULATIVE LOAD BY CAPACITY FACTOR

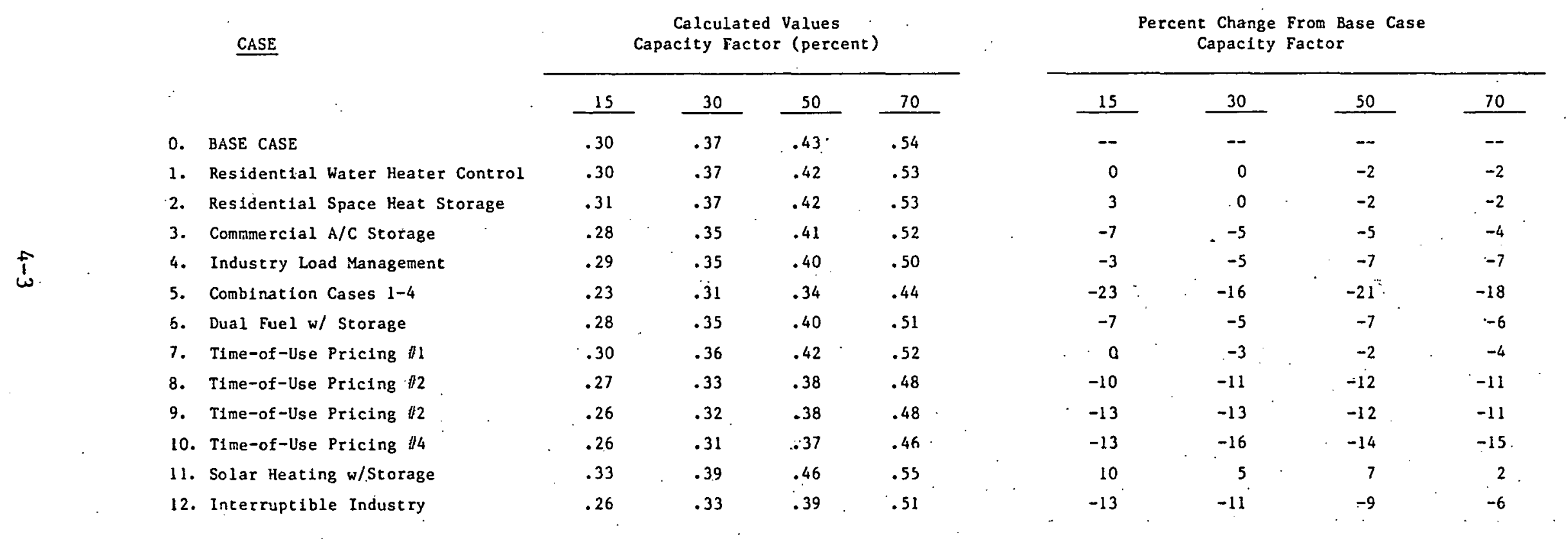


Table 4-2

RESULTS OF CAPACITY FACTOR ANALYSIS SOUTH CENTRAL REGION (YEAR 2000) CINULLATIVE LOAD BY CAPACITY FACTOR

\begin{tabular}{|c|c|c|c|c|c|c|}
\hline & & CASE & & $\begin{array}{l}\text { a-cul } \\
\text { IEy F }\end{array}$ & $\begin{array}{l}\text { Value } \\
\text { (per }\end{array}$ & \\
\hline & & & 15 & 30 & 50 & 70 \\
\hline & 0. & BASE CASE : & .40 & -45 & .52 & .63 \\
\hline & 1. & Residential Water Heater Control & .40 & .45 & .52 & .62 \\
\hline$\downarrow$ & 2. & Residential Space Heat Storage & .39 & .45 & .52 & .63 \\
\hline & 3. & Commerclal A/C Storage & .36 & .39 & .47 & .57 \\
\hline & 4. & Industry . Load Management & .39 & .44 & .50 & .58 \\
\hline & 5. & Combination Cases $1-4$ & .33 & .38 & .44 & .50 \\
\hline & 6. & Dual Fuel w/ Storage & .40 & .44 & .51 & .63 \\
\hline & 7. & Time-of-Use Pricing $\| 1$ & .41 & .44 & .52 & .51 \\
\hline & 8. & Time-of-Use Pricing $\# 2$ & .38 & .41 & .49 & .57 \\
\hline ' & 9. & Time-of-Use Pricing $\# 3$ & .36 & .39 & .47 & .57 \\
\hline & 10. & Time-of-Use Pricing & .36 & .38 & .46 & .56 \\
\hline & 11. & Solar Heating, w/Storage & .42 & .46 & .53 & .64 \\
\hline & 12. & Interruptible Industry & .36 & .41 & .48 & .61 \\
\hline
\end{tabular}

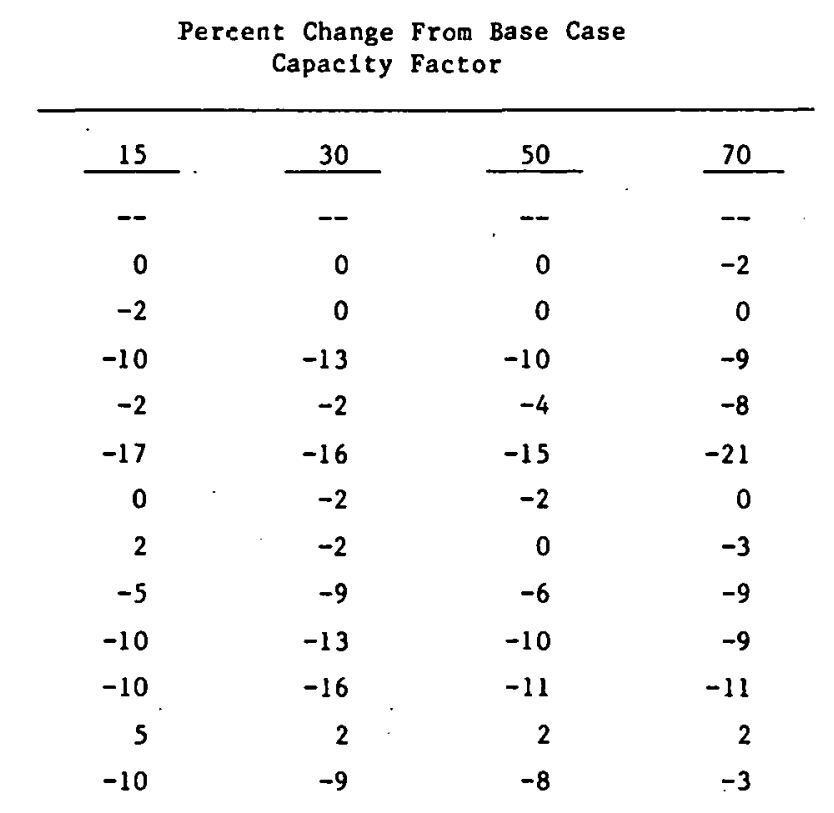


For purposes of analysis, four technologies were chosen to represent thermal generating options in the year 2000: nuclear, coal, oil-fired steam boiler (a traditional intermediate technology), and oil-fired combustion turbine. Table 4-3 itemizes the cost and performance data for the options. The values in the table are consistent with planning assumptions currently being used at the Electric Power Research Institute [12]. The oil price of $\$ 6.00$ per million Btu is equivalent to $\$ 36.00$ per barrel. This price is comparable to current estimates of future synthetic fuel costs. The liquid fuel can therefore be considered to be either oil or a. coal-derived liquid. Nuclear capacity in the year 2000 is limited to amounts already installed or under construction. Financlal assumptions used in the model to calculate levelized costs are listed In Table 4-4.

The results of the system optimization for base case demands with and without load management (the base case and load management case [Case 5], Table 3-7) are shown in the first two lines of Tables 4-5 and 4-6. As these tables indicate, the optimal generation mix in the North Central Region includes $28 \%$ combustion turbines without load management and $24 \%$ with mauagement. In the South Central Region the corresponding percentages are 37 and 30. In other words, heavy load management decreases the optimal amount of peaking capacity by about 5 to 10 percentage points but leaves a substantial requirement.

The capacity optimizing model used here probably overstates the amount of peaking capacity in the optimal generation mix by about $10-15 \%$. The model uses a derating procedure to account for unit unavailability. This method tends to underestimate peaking and intermediate usage, which in turn biases results toward these higher operating cost technologies. A probabilistic simulation is required to more accurately assess the operation of IPTs. However, the level of accuracy achieved with the derating method is consistent with our stated objectives. 
Table 4-3

THERMAL GENERATION ASSUMPTIONS (BASE CASE)

(1978 DOLLARS)

Oil

Combustion

Turbine

180

Coal

Nuclear

Steam-0i1

Capital Costs $(\$ / k W)$

180

900

1000

440

Life (Years)

20

30

30

30

Heat Rate (Btu/kWh)

12400

10300

13400

9700

á

Availability $(\%)$

93

88

80

80

Scheduled Maintenance (\%)

0

10

$0^{a}$

0

Fuel Costs $\left(\$ / 10^{6} \mathrm{Btu}\right)$

6.00

1.65 .

1.00

6.00

Variable 0\&M ( $\$ / \mathrm{kWh})$

0.001

0.003

0

0.001

Fixed $0 \& M \cdot(\$ / k W-y r)$

0

14

1.4

a. Major nuclear maintenance is treated as not able to be scheduled.

b. Three-percent escalation to year 2000, 0\% after.

c. Escalation above general inflation. 
Table 4-4

\section{FINANCIAL ASSUMPTIONS}

\section{(Percentage)}

Discount Rate

Inflation Rate

Tax Rate

Debt Rate

Debt Ratio

Property Tax and Insurance
$10 \%$

$6 \%$

$48 \%$

$8 \%$

$65 \%$

$2 \%$ 
Table 4-5

RESULTS OF CAPACITY OPTIMIZATION NORTH CENTRAL REGION ${ }^{a}$

CASE

Relactve Instalied Capac1ty - Year 2000 as Percertage of 1980 Peak Demand

(Percentage of Installed Capacity in Year 2000)

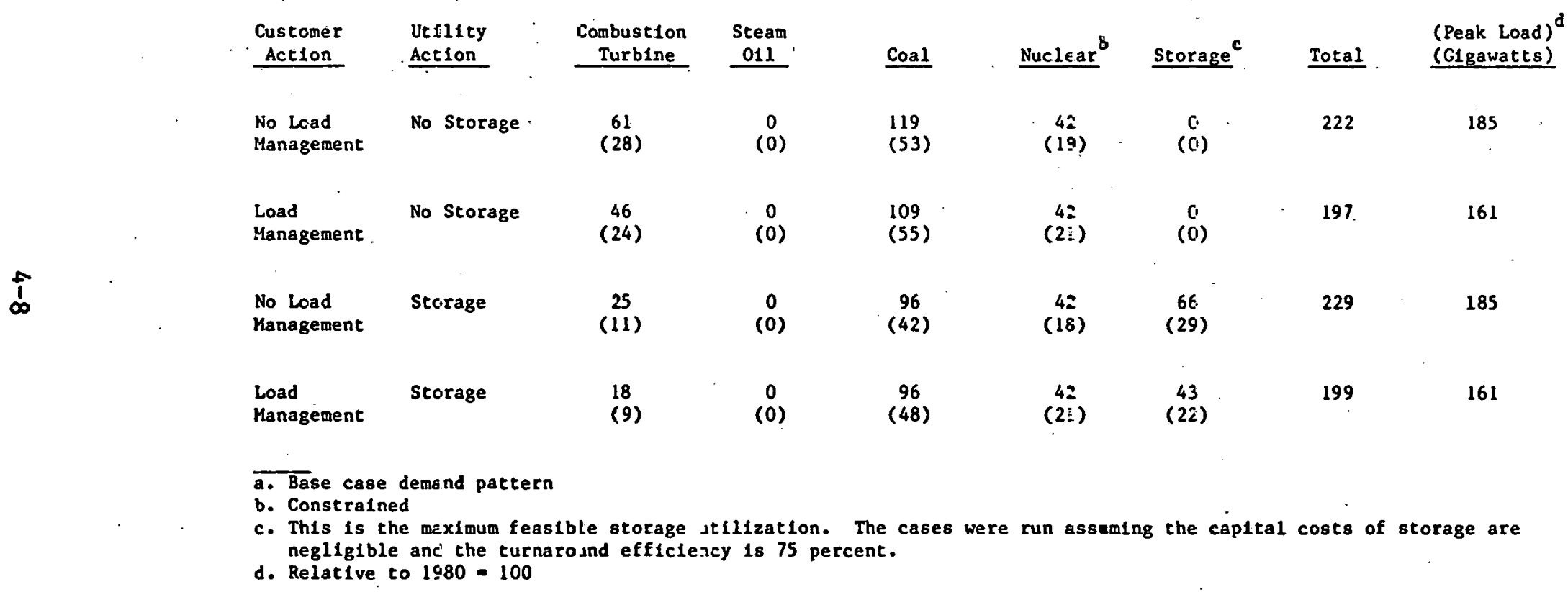


Table 4-6

RESULTS OF CAPACITY OPTIMIZATION SOUTH CENTRAL REGION ${ }^{a}$

$\underline{\text { CASE }}$

Relative Installed Capacity - Year 2000 as Percentage of 1980 Peak Demand

(Percentage of Installed Capacity in Year 2000)

\begin{tabular}{|c|c|c|c|c|c|c|c|c|}
\hline $\begin{array}{c}\text { Customer } \\
\text { Action }\end{array}$ & $\begin{array}{l}\text { Utility } \\
\text { Action }\end{array}$ & $\begin{array}{c}\text { Combustion } \\
\text { Turbine } \\
\end{array}$ & $\begin{array}{l}\text { Steam } \\
011 \\
\end{array}$ & Coal & Nuclear ${ }^{b}$ & Storage $^{c}$ & Total & $\begin{array}{l}\text { (Peak Load) } \\
\text { (Gigawatts) }\end{array}$ \\
\hline $\begin{array}{l}\text { No Load } \\
\text { Management }\end{array}$ & No Storage & $\begin{array}{c}91 \\
(37)\end{array}$ & $\begin{array}{c}0 \\
(0)\end{array}$ & $\begin{array}{l}.136 \\
(55)\end{array}$ & $\begin{array}{l}20 \\
(8)\end{array}$ & $\stackrel{0}{(j)}$ & 247 & $206^{\circ}$ \\
\hline $\begin{array}{l}\text { Load } \\
\text { Management }\end{array}$ & No Storage & $\begin{array}{c}63 \\
(30)\end{array}$ & $\begin{array}{c}0 \\
(0)\end{array}$ & $\begin{array}{l}126 \\
(60)\end{array}$ & $\begin{array}{c}20 \\
(10)\end{array}$ & $\stackrel{0}{(1)}$ & 209 & 174 \\
\hline $\begin{array}{l}\text { No Load } \\
\text { Management }\end{array}$ & Storage & $\begin{array}{c}45 \\
(18)\end{array}$ & $\begin{array}{c}0 \\
(0)\end{array}$ & $\begin{array}{l}108 \\
(43)\end{array}$ & $\begin{array}{l}20 \\
(8)\end{array}$ & $\begin{array}{l}80 \\
(32)\end{array}$ & 253 & 206 \\
\hline $\begin{array}{l}\text { Load } \\
\text { Management }\end{array}$ & Storage & $\begin{array}{c}23 \\
(11)\end{array}$ & $\begin{array}{c}0 \\
(0)\end{array}$ & $\begin{array}{l}108 \\
(51)\end{array}$ & $\begin{array}{l}20 \\
(9)\end{array}$ & $\begin{array}{c}63 \\
(25)\end{array}$ & 213 & 174 \\
\hline
\end{tabular}

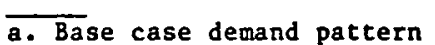

b. Constrained

c. This is the maximum feasible storage utilization. The cases were run assuming the capital costs of storage are

negligible and the turnaround efficiency is 75 percent.

d. Relative to $1980=100$ 
MAXIMUM UTILIZATION OF ENERGY STORAGE

The system optimization model is capable of including storage options in the generation mix, and the last two cases in Tables 4-5 and 4-6 show the optimal (least-cost) generation mix when a very inexpensive (free) storage option with an efficiency of $75 \%$ is available. In these cases, storage devices account for about $20-30 \%$ of installed capacity and decrease the amount of combustion turbines by a proportionate amount. Load management decreases the potential for storage by three percentage points in the North and seven points in the South.

These results must be interpreted very carefully because of the capital costs of storage that have been deliberately ignored. (This was done to establish an upper limit on sturage utilization.) The energy storage capacity installed in the cases is equivalent to a 15-20 livur sutput at full discharge. This implies that some of the storage capacity is being used to store energy on weekends for use on weekdays, that is, weeklycycle. We estimate from other model runs that two-thirds of the storage capacity, measured in megawatts, has a daily duty cycle and that this fraction competes with the load management alternatives.

One counter-intuitive result of the model runs is that introduction of cost-free storage capacity reduces the amount of coal capacity in the "optimal" mix. A detailed explanation of why this happens is included in Appendix H. For any reasonable estimates of storage costs, this effect would be greatly reduced; in most cases, the addition of scorage will increase the optimal fraction of coal and nuclear capacity.

Somewhat surprisingly, even with maximum storage utilization (at $75 \%$ efficiency), the optimal generation mix will still include a significant amount of generation capacity with the generic characteristics of a combustion turbine (i.e., fixed costs of $\$ 180 / \mathrm{kW}$ and operating costs of about 70 $\mathrm{mills} / \mathrm{kWh}$ ). This result is explained by the relatively short duration of very high demand levels and the role of a low-fixed-cost technology, such as combustion turbines, in meeting reserve requirements. 


\section{Section 5}

\section{REFERENCES}

[1] The 1978 Annual Electric Power Survey. A report of the Electric Power Survey Committee of the Edison Electric Institute, April 1978.

[2] W. E. Balson and S. M. Barrager. Integrated Analysis of Load Shapes and Energy Storage. Final Report prepared by Decision Focus Incorporated for the Electric Power Research Institute, May 1979. EPRI. EA-970.

[3] Synthetic Electric Utility Systems for Evaluating Advanced Technologies. Final Report prepared by Power Technologies, Inc. for the Electric Power Research Institute, February 1977. EPRI-EM-285.

[4]. Regional Reference Energy Systems. Topical Report prepared by Brookhaven National Laboratory for the Electric Power Research Institute, June 1977. EPRI EA-462.

[5] J. Carney and E. Hirst. Residential Energy Use to the Year 2000: Conservation and Economics. Oak Ridge National Laboratory, September 1977. ORNL/CON-13.

[6]. Jerry R. Jackson et al. The Commercial Demand for Energy: A Disaggregated Approach. Oak Ridge National Laboratory, April 1978. ORNL/CON-15.

[7] Electrical Energy Demand 1979-1988. Northeast Utilities Systems, March 1, 1979.

[8] An Assessment of Energy Storage Systems Suitable for Use by Electric Utilities. Final Report prepared by Public Service Electric and Gas Company for the Electric. Power Research Institute, July 1976. EPRI EM-264.

[9] U.S. Department of Commerce. Monthly Normal Percent of Temperature, Precipitation, and Heating and Cooling Degree Days 1941-1970, August. 1973.

[10] Rate Design and Load Control, Issues and Direction, Electric Utility Rate Design Study. A report to the National Association of Regulatory Utility Commissions, November 1977.

[11] D. Caves and L. Christensen. "Econometric Analysis of the Wisconsin Residential Time-of-Use Electricity Pricing Experiment." In Proceedings of the EPRI Workshop on Modeling and Analysis of Electricity Demand by Time-of-Day, June 1978. 
[12] Technical Assessment Guide. Palo Alto: Electric Power Research Institute, June 1978. EPRI PS-866-SR.

[13] E. Hirst and J. Carney. The ORNL Englneering-Economic Model of Residential Energy Use. Oak Ridge National Laboratory, Oak Ridge, Tennessee, July 1978. ORNL/CON-24.

[14] Potomac Electric Power Company. "Elements of Load," Second Printing, June 1977.

[15] Environmental Impacts, Efficlency, and Cost of Energy Supply and End Use. Final Report prepared by Hittman Associates, Inc., November 1974. HIT-593.

[16] Solar Heating and Cooling of Buildings (SHACOB): Requirements Definition and Impact Analysis. Final report prepared by the Aerospace Corporation for the Electric Power Research Institute, June 1978. : ER-808, Volume 1. 
Appendix A

FORMULATION OF THE DEMAND MODEL'

This appendix presents the mathematical formulation of the demand model. It is organized by the same three submodels described in Section. 2, that is, the demand growth submodel, the energy allocation submodel, and the load shape construction submodel.

The notation used here is somewhat unconventional. The variable names are the same as those used in the APL language implementation of the model. They are made up of whole words that convey the meaning of variables. Subscripts are used here (although not in APL) to indicate over which problem dimensions the variables are defined. Finally, parentheses surrounding a $\mathrm{T}$ or $\mathrm{T}+1$ indicate which variables are recalculated for each model year.

The indices are as follows:

$$
\begin{array}{ll}
i=\text { end use }(1 \text { to } 10) & \text { see Table } 2-2 \\
j=\text { technology }(1 \text { to } 8) & \text { see Table } 2-2 \\
k=\text { hour of the day }(1 \text { to } 24) & \\
h=\text { day type }(1 \text { to } 11) & \text { see Table } 2-3 \\
s=\text { season ( } 1 \text { =winter, } 2=\text { summer, } & 3=\text { fall/spring) } \\
t=\text { year interval }(1=1972-1980, & 2=1981-1990,3=1991-2000)
\end{array}
$$

\section{DEMAND GROWTH SUBMODEL}

The demand growth submodel calculates the values of three state variables.

$$
\begin{aligned}
\text { MARKET SIZE }_{i}(T)= & \begin{array}{l}
\text { Amount of service level energy } 1 \text { in end use } i \text { in } \\
\text { year } T\left(10^{\left.12_{B t u} / y r\right)}\right.
\end{array} \\
\text { MARKET SHARE }_{1 j}(T)= & \begin{array}{l}
\text { Fraction of energy in end use } 1 \text { allocated to } \\
\text { technology } j \text { in year } T
\end{array}
\end{aligned}
$$


$\begin{aligned} \text { INVERSE EFICIENCY }_{i j}(T)= & \text { The reciprocal of the efficiency of } \\ & \text { technology } j \text { of end use } i \text { in year } T\end{aligned}$

which have initial conditions

ORIGINAL MARKET SIZE $_{\mathbf{i}}$
ORIGINAL MARKET SHARE $_{\mathbf{i j}}$
1/ORIGINAL EFFICIENCY $_{\mathbf{i} j}$

The market size is computed very simply as

(1) MARKET SIZE $_{i}(T+1)=\left(1+\right.$ GROWTH RATE $_{i t}-$ RETIREMENT RATE $\left._{i t}\right)$

$$
x \text { MARKET } \operatorname{SIZE}_{i}(T)
$$

The market share in year $T+1$ is found as a weighted average of the market share in year $T$, the share of new installations in year $T$, and the shares of replacements and retirements in year $\mathrm{T}$.

(2) MARKET $\operatorname{SHARE}_{i j}(T+1)=A_{i j}(T)+B_{i j}(T)+C_{i j}(T)-D_{i j}(T)-E_{i j}(T)$

where

$$
\begin{aligned}
A_{i j}(T)= & \text { MARKET SHARE }_{1 j}(T) \\
B_{i j}(T)= & \text { GROWTH RATE }_{1 t} \times \text { INSTALLATIUN SHAKE }_{i j t} \\
C_{i j}(T)= & \text { REPLACEMENT RATE }_{i}(T) \times \sum_{j_{1}} \text { REPLACEMENT SHARE }_{i j}(T) \\
& x \text { REPLACED BY }_{1 j_{1} j t}
\end{aligned}
$$

$D_{i j}(T)=$ REPLACEMENT $_{\text {RATE }_{i}}(T) \times$ REPLACEMENT SHARE $_{i j}(T)$

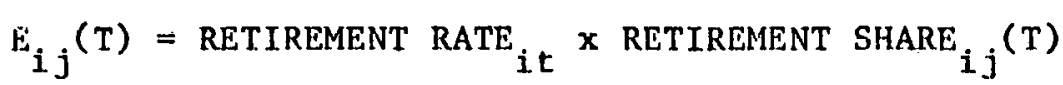

with

$$
\begin{aligned}
& \text { REPLACEMENT FRACTION }_{i j}=1 \text { /SERVICE LIFE }_{i j} \\
& \text { REPLACEMENT } \operatorname{RATE}_{1}(T)= \\
& \sum_{j} \text { REPLACEMENT FRACTION }_{i j} \times{\text { MARKET } \text { SHARE }_{i j}(T)}
\end{aligned}
$$




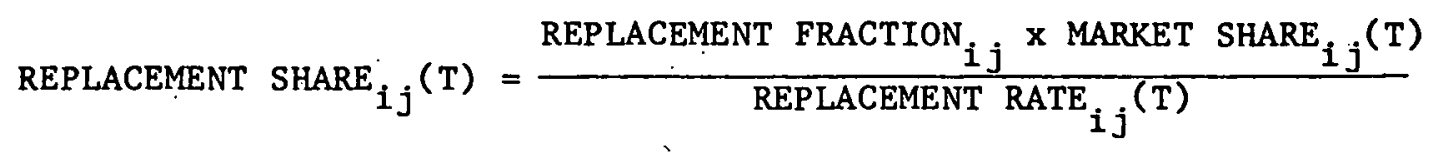

As a first-order approximation we let

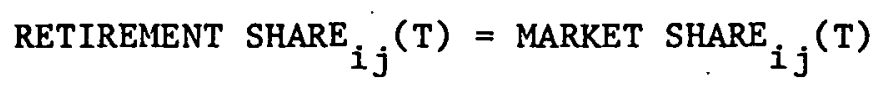

With this assumption, retirements can be dropped from the system, replacing growth rate by the net growth rate, which is

$$
\text { GROWTH RATE }_{\text {it }} \text { - RETIREMENT RATE }{ }_{\text {it }}
$$

With a more complicated definition of retirement share, this elimination would not be possible.

Finally, the inverse efficiency is found as a weighted average of the efficiencies of old and new technologies, or

(3) INVERSE EFFICIENCY $_{1 j}(\mathrm{~T}+1)=$

$$
\begin{aligned}
& A_{1 j}(T) \times \text { INVERSE EFFICIENCY }_{i j}(T) \\
& +\left(B_{i j}(T)+C_{i j}(T)\right) \times \text { NEW INVERSE EFFICIENCY } \\
& i j
\end{aligned}
$$

where

$$
\begin{aligned}
& \text { NEW INVERSE EFFICIENCY }_{i j}(T)=1 / \text { NEW EFFICIENCY }_{1 j t} \\
& \text { OLD INVERSE EFFICIENCY }_{i j}(T)=1 / \text { NEW EFFICIENCY }_{i j t}
\end{aligned}
$$

where

$$
t *=t-\operatorname{SERVICE} \operatorname{LIFE}_{i j}
$$


In the equations just presented, model inputs are

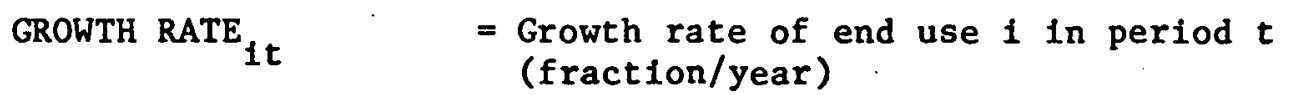

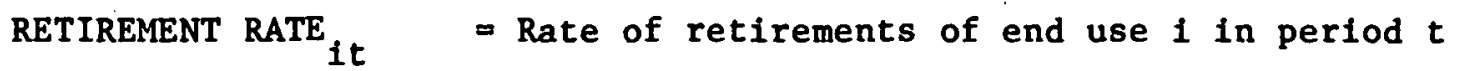

$$
\begin{aligned}
& \text { INSTALLATION SHARE }{ }_{i j t}=\text { Fraction of new growth in end use } i \text { that is } \\
& \text { allocated to technology } j \text { in period } t \\
& \begin{aligned}
\text { REPLACED BY } & j_{1} j_{2} t=\begin{array}{l}
\text { Fraction of replacements of } \\
\end{array} \quad \text { technology } j_{1} \text { by technology } j_{2} \text { in end use }
\end{aligned} \\
& 1 \text { and period } t
\end{aligned}
$$

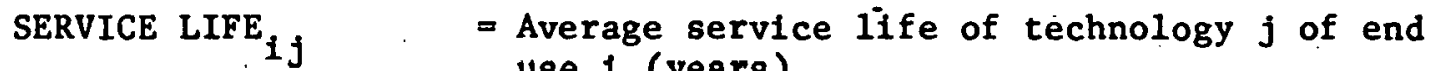

$$
\begin{aligned}
& \text { use } 1 \text { (years) } \\
& \begin{aligned}
\text { NEW EFFICIENCY }_{1 j t}= & \text { Efficiency of new units of technology } j \text { of } \\
& \text { cnd uoc } i \text { in period } t
\end{aligned}
\end{aligned}
$$

All other varlables used above are intermediate variables defined by the right-hand side of the equation in which they are used.

ENERGY ALLOCATION SUBMODEL

The energy allocation submodel calculates two quantities:

$$
\begin{aligned}
& \text { ANNUAL BTU } \mathrm{BI}_{i .1}=\text { The amount of electric energy used by } \\
& \text { technology } j \text { of end use } 1 \text { in the year under } \\
& \text { consideration ( } 10^{12} \mathrm{Btu} / \text { year) } \\
& \text { ENERGY ALLOCATION }{ }_{h 1} \text { = The amount of electric energy in a single } \\
& \text { day of type h uocd by tcchnology } j \text { of cnd uoc } 1 \\
& \left(10^{6} \mathrm{kWh} / \mathrm{day}\right)
\end{aligned}
$$

The annual energy by end use and technology is a simple function of the market size, market share, and efficiency calculated by the energy growth submode1. Let $\mathrm{T}_{\mathrm{f}}$ represent the year that is being estimated. Then

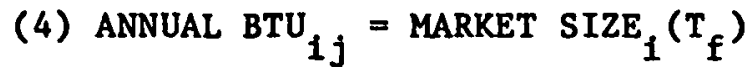

$$
\begin{aligned}
& \times \text { MARKET SHARE }_{i j}\left(T_{f}\right) \\
& x \text { INVERSE EFFICIENCY }_{i j}\left(T_{f}\right)
\end{aligned}
$$


where

$$
\begin{aligned}
\text { FRACTION ELECTRIC }_{i j}= & \text { The electric fraction of the total service } \\
& \text { level energy in technology } j \text { of end use } i \\
& \text { (varies between } 0 \text { and } 1 \text { ) }
\end{aligned}
$$

Then the energy allocation by day type is calculated by

(5)

$$
\text { ENERGY ALLOCATION }
$$

$$
\mathrm{N}_{\mathrm{hij}}=
$$

where

BTU TO KWH

$=$ Conversion factor from $10^{12}$ Btu to GWh

$=10^{6} / 3413$

DAY TYPE SPLIT $_{h i j}$

$=$ The fraction of the annual energy in technology $j$ of end use $i$ that is in a single day of type $h$

The split by day type is determined by seasonal splits and energy ratios by day type, that is, peak-to-normal, Saturday-to-weekday, and Sunday-toweekday.

Following is the calculation for winter; the other seasons are the same, except fall/spring has no peak-to-normal term.

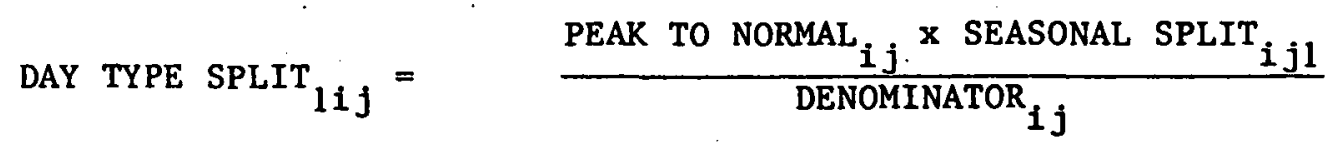

$$
\operatorname{DAY}_{\operatorname{TYPE}} \operatorname{SPLIT}_{2 i j}=\frac{1 \times \text { SEASONAL SPLIT }_{i j 1}}{\text { DENOMINATOR }_{i j}}
$$

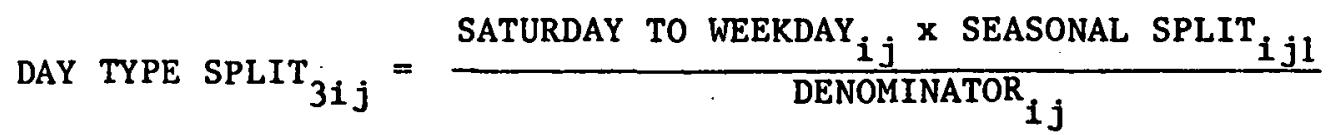$$
\operatorname{DAY}_{\text {TYPE }} \operatorname{SPLIT}_{4 i j}=\frac{\text { SUNDAY } \text { TO } \text { WEEKDAY }_{i j} \times \text { SEASONAL SPLIT }_{i j 1}}{\text { DENOMINATOR }_{i j}}
$$ 
where

$$
\begin{aligned}
\text { DENOMINATOR }_{i j} & \text { PEAK TO NORMAL }_{i j} \mathbf{x} \cdot \text { NUM }_{1} \\
& +1 \times \text { NUM }_{2} \\
& + \text { SATURDAY TO WEEKDAY }_{i j} \times \mathrm{NUM}_{3} \\
& + \text { SUNDAY TO WEEKDAY }_{i j} \mathbf{x} \text { NUM }_{4}
\end{aligned}
$$

and where the following are input quantities:

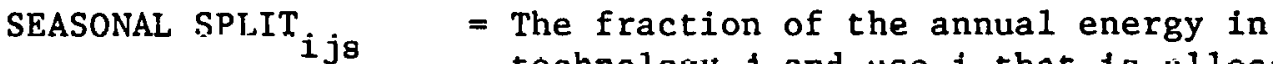

$$
\begin{aligned}
& \text { technology } j \text { end use } i \text { that is allocated to } \\
& \text { season } s \\
& \text { PEAK TO NORMAL }_{i j} \quad=\text { Ratio of energy in peak vs normal days for } \\
& \text { technology } j \text { end use } i \\
& \text { SATURDAY TO WEEKDAY }{ }_{i j}=\text { Ratio of energy in Saturdaye to weekdays. } \\
& \text { SUNDAY TO WEEKDAY }{ }_{i j} \quad=\text { Ratio of energy in Sundays to weekdays } \\
& \text { NUM } h \text { Number of days of type } h
\end{aligned}
$$

\section{LOAD SHAPE CONSTRUCTION SUBMODEL}

Given the energy allocation by day type, calculated in the previous section, and representative load profiles of technologies, it is simple to compute system load shape by day type. Let

$$
\text { LOAD SHAPES }_{h k}=\text { Hourly system load shape for day type } \mathrm{h} \text {. }
$$

Ihen

(6) LOAD SHAPES $_{h k}=\sum_{j} \sum_{i}$ NORMALIZED LOAD SHAPES $_{i j k}$

$$
\mathbf{x} \text { ENERGY ALLOCATION }{ }_{h i j}
$$

where

$$
\text { NORMALIZED LOAD SHAPES }_{i j k}=\frac{\text { STANDARD LOAD SHAPES }_{i j k}}{\sum_{k} \text { STANDARD LOAD SHAPES }_{i j k}}
$$


The normalized load shapes are computed so that they have unit area. They are calculated from the input quantity

STANDARD LOAD SHAPES $_{i j k}=$ Hourly load profile of technology $j$ of end use i (specified relative to a peak of 100 ) 


\author{
Appendix B \\ FORMULATION OF THE LOAD MANAGEMENT MODEL
}

MODEL DESCRIPTION

The load management submodel consists of three submodels as described. in Section 2.

- Energy Demand Submodel.

- Time-of-Use Demand Submodel

- Customer Storage Submodel

The energy demand submodel consists of a demand function that was chosen to be of the constant elasticity of substitution (CES) form. This form has the advantage that the parameter that defines it is the price elasticity of energy. Therefore, its value is easy to interpret.

The time-of-use demand submodel consists of a function that allocates a given amount of energy over hours of the day. The fraction of energy consumed in any given. hour is proportional to a "preferred" fraction, the fraction that would be consumed in the absence of time-of-use prices, and inversely proportional to the relative price during the period. In the simplest case, a single parameter, called the hourly elasticity, governs the extent of hourly shifts in consumption. This parameter was varied in the sensitivity runs of Chapter 3 .

The customer storage submodel is also a function that allocates energy over hours of the day. It is based on the ability of storage to provide consumption of energy in a given hour and to buy it from other hours. If purchases are made outside the hour of consumption, an efficiency loss is 
suffered. However, if prices in other hours are sufficiently lower than the period's own price, it will be economical to make purchases from other hours.

The storage model is an approximation of an actual storage device and accounts for prices, consumption preferences, and efficiency losses. There are no specific limits on charging or discharging rate. However, the storage flexibility parameter (defined below) can be chosen to reasonably approximate physical storage systems. After some experimentation, a flexibility parameter of 5 was found to allow a shift of $80-90 \%$ of energy in peak to off-peak periods. Values lower than that did not allow enough storage flexibility, while higher values resulted in all the energy's being shifted to the one or two lowest priced periods.

The model equations and sequence of calculations are shown in Figure B-1, and the model variables are defined as follows:

Prices and Quantities.

$q_{1}^{c}=$ energy consumed in period 1 ( 12 periods per day)

$q_{j}^{e}=$ energy purchased in period $j$ $\begin{aligned} p_{i}^{c}= & \text { price of energy in period } i \cdot a s \text { perceived by consumer } \\ & \text { after effect of storage device }\end{aligned}$

$\mathrm{p}_{j}^{\mathrm{e}}=\underset{\text { price of energy in period } j \text { (from utility, } 1 . e ., \text { the }}{\text { market price) }}$

$\hat{\mathbf{p}}=$ average daily price of electric energy (sum of hourly prices weighted by the fraction of energy used in each hour)

$q_{c}=$ total energy consumed per day

Storage Submodel Variables

$p_{i j}=$ price of energy used in period $i$ and purchased in period $j$

$\mu_{i j}=\begin{aligned} & \text { fraction of the energy used in period } i \text { that is purchased in } \\ & \text { period } j\end{aligned}$ 
ENERGY DEMAND SUBMODEL

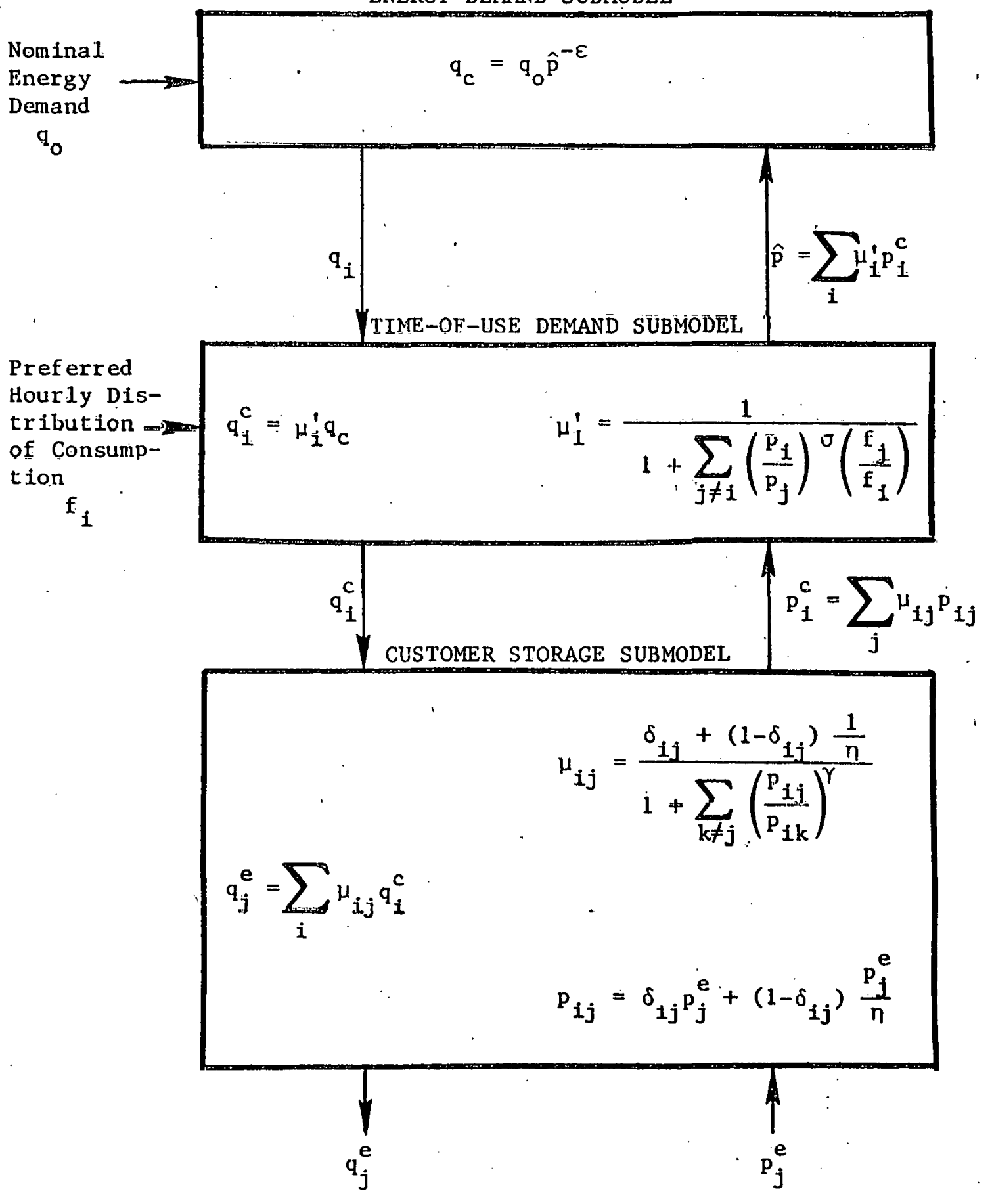

Figure B-1. Detall of the Load Management Model 


$$
\begin{aligned}
\delta_{i j} & =\operatorname{delta} \text { function }\left(\delta_{i j}=1 \text { if } i=j\right. \\
& =0 \text { if } i \neq j) \\
\gamma & =\text { storage flexibility parameter } \\
\eta & =\text { storage efficiency parameter }
\end{aligned}
$$

Time-of-Use Submodel Variables

$$
\begin{aligned}
f_{i}= & \text { preferred fraction of daily consumption consumed in period } i \\
& \text { (derived directly from consumption pattern when prices are equal } \\
& \text { in all hours) } \\
\mu_{i}^{\prime}= & \text { actual fraction of energy consumed in period } i \text { (after price } \\
& \text { effect) } \\
\sigma= & \text { hourly elasticity parameter }
\end{aligned}
$$

\section{Energy Demand Submodel Variables}

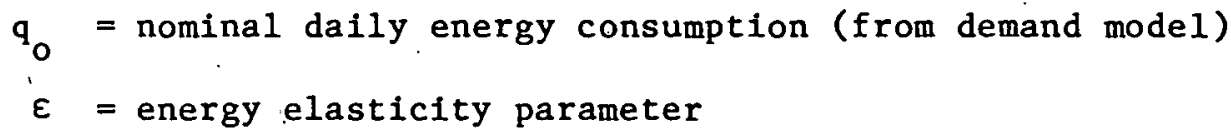

\section{MODEL COMPUTATIONS}

The calculations shown in Figure B-1 start with the input of hourly market prices $\left(p_{j}^{e}\right)$ to the customer storage model. Here the share of consumption in period $i$ purchased in period $j\left(\mu_{i j}\right)$ is calculated. An effective price after storage $\left(p_{i}^{c}\right)$ is then calculated and passed to the time-of-use demand submodel. Here the pattern of hourly consumption is calculated based on the preferred distribution $\left(f_{i}\right)$ and the effective prices. A daily average price $(p)$ is then computed and passed to the demand function in the energy demand submodel. Given nominal energy demand $\left(q_{o}\right)$, the actual time-of-use price demand $\left(q_{c}\right)$ is determined. The total energy (daily) consumption is then passed back down to the time-of-use model, where consumption by hour is determined. Finally, hourly consumption is passed to the customer storage model, where hourly purchases are determined. 
If the customer storage model is disconnected from the time-of-use model, hourly prices are input directly into the time-of-use model in place of $p_{1}^{c}$ and purchases are taken to be $q_{1}^{c}$, the output of the time-ofuse demand submodel.

To run a storage case without the effects of the time-of-use and energy demand submodels, the elasticity parameters $\sigma$ and $\varepsilon$ are set to very small numbers $\left(10^{-6}\right)$.

\section{CALCULATION OF ELASTICITIES}

To allow comparisons with price elasticities presented in the literature, a formula for the price elasticities implied by the energy demand model and the time-of-use model is presented here.

From basic microeconomics, $\varepsilon_{1 j}$ (the price elasticity of consumption in period $i$ with respect to the price in period $j$ ) is defined as

$$
\varepsilon_{i j}=\frac{p_{j}}{q_{i}} \frac{\partial q_{i}}{\partial p_{j}}
$$

where $q_{i}$ is the quantity consumed in period 1 and $p_{j}$ is the price in period $j$.

From the functiono of Figurc B-1, the prioo elastialty can be computed as

$$
\varepsilon_{i j}=\sigma_{i j}-z_{j} \varepsilon
$$

where $\sigma_{i j}$ is the price elasticity of the allocation function in the time-of-use demand submodel, $\varepsilon$ is the energy elasticity parameter, and $z_{j}$ is the share of expenditures allocated to period $j$. The quantity $z_{j}$ is simply

$$
z_{j}=\frac{\mu_{j}^{\prime} p_{j}}{\sum_{i}^{\mu_{i}^{\prime}} p_{i}}
$$


The price elasticity of the allocation function $\left(\sigma_{i j}\right)$ can be computed. for diagonal terms as

$$
\sigma_{11}=-\sigma\left(1-\frac{p_{i}^{-\sigma} f_{i}}{\sum_{k} p_{k}^{-\sigma} f_{k}}\right)
$$

and for off-diagonal terms as

$$
\sigma_{i j}=\sigma \frac{p_{j}^{-\sigma} f_{j}}{\sum_{k} p_{k}^{-\sigma} f_{k}}
$$

where $\sigma$ is the hourly elasticity parameter and $f_{1}$ is the preferred consumption fraction.

If the value of $\sigma$ is small, on the order of 0.1 or 0.2 , the above formulas for $\sigma_{1 j}$ can be approximated as

$$
\sigma_{11} \cong-\sigma\left(1-f_{1}\right)
$$

and

$$
\sigma_{i j} \cong \sigma_{j}
$$

Furthermore, if there are a large number of periods so that each $f_{i}$ is small, then

$$
\sigma_{i i} \cong-\sigma
$$

The value of $\sigma$ can thus be interpreted as follows: For a $1 \%$ increase in the price of period 1 , the consumption in period 1 decreases by approximately $\sigma$ times $1 \%$. Consumption 1 all other periods increases slightly so that total consumption remains constant. 
To determine the effect of both changes in consumption between periods and changes in the average level of consumption, Eq. (1), which combines $\sigma_{i j}$ and $\varepsilon$, must be used. Using the approximations of equations (5) and (6) together with (1), the total elasticity of substitution can be written in matrix form as ( 2 period example)

$$
\varepsilon_{i j}=\left(\begin{array}{cc}
-\sigma\left(1-f_{1}\right) & \sigma f_{2} \\
\sigma f_{1} & -\sigma\left(1-f_{2}\right)
\end{array}\right)-\left(\begin{array}{cc}
z_{1} \varepsilon & z_{2} \varepsilon \\
z_{1} \varepsilon & z_{2} \varepsilon
\end{array}\right)
$$

As a check on the reasonableness of the mode1, a comparison can be made with the results of the Wisconsin residential time-of-use pricing experiment as reported in Reference [11]. 'Assuming a price ratio of 2:1 for period 1 (peak) versus period 2 (off-peak), a consumption pattern of $f_{1}=1 / 3$, $\mathrm{f}_{2}=2 / 3$, and parameter values $\varepsilon=0.5, \sigma=0.1$, (8) gives

$$
\varepsilon_{i j}=\left(\begin{array}{ll}
-0.32 & -0.18 \\
-0.22 & -0.28
\end{array}\right)
$$

The corresponding elasticities from Reference [11], with price ratio $2: 1$ and $f_{1}=1 / 3, f_{2}=2 / 3$, are

$$
\varepsilon_{i j}=\left(\begin{array}{ll}
-0.31 & -0.19 \\
-0.21 & -0.29
\end{array}\right)
$$

Clearly, the time-of-use pricling model deflned in Figure B-1 can fit observed experimental behavior. 


\author{
Appendix C \\ ELECTRIC CAPACITY EXPANSION AND OPERATION MODEL*
}

This appendix reviews the mathematical formulation of the model used to estinate the need for peaking and intermediate capacity and the limitations on the application of storage. The model was formulated to optinize generation mix where several energy storage technologies are available. It takes annual demand as it is described by 11 representative days, each day divided into 12 two-hour periods. The model is able to treat both daily and weekly storage duty cycles.

The objective of the model is to choose the mix of generation and storage capacity that minimizes the levelized cost of electricity, given an hourly characterization of annual demand. The optimization is formulated as a linear program. System rellability requirements are treated by stipulating a minimum net resęrve margin of $20 \%$ and derating generating capacity according to its availability. Annual maintenance that can be scheduled is allocated in a manner that minimizes total capital and fuel costs. Table C-1 presents the mathematical formulation of the model.

The terms in that table are defined as follows: XGEN $_{M}=\underset{(k W)}{\text { Existing Installed capacity of thermal generation type } M}$

GEN $_{M}=$ New installed capacity of thermal generation type $M(\mathrm{~kW})$

$C(G E N)_{M}=$ Annualized cost of new capacity for thermal generation type $M(\$ / k W h)$

XSMW $_{N}=$ Existing installed power capacity of storage type $N(\mathrm{~kW})$

*This model was formulated by DFI during a technical planning etudy conducted"for the Electric Power Research Institute:

C-1. 
LINEAR PROGRAMMING FORMULATION OF CAPACITY EXPANSION AND OPERATION MODEL

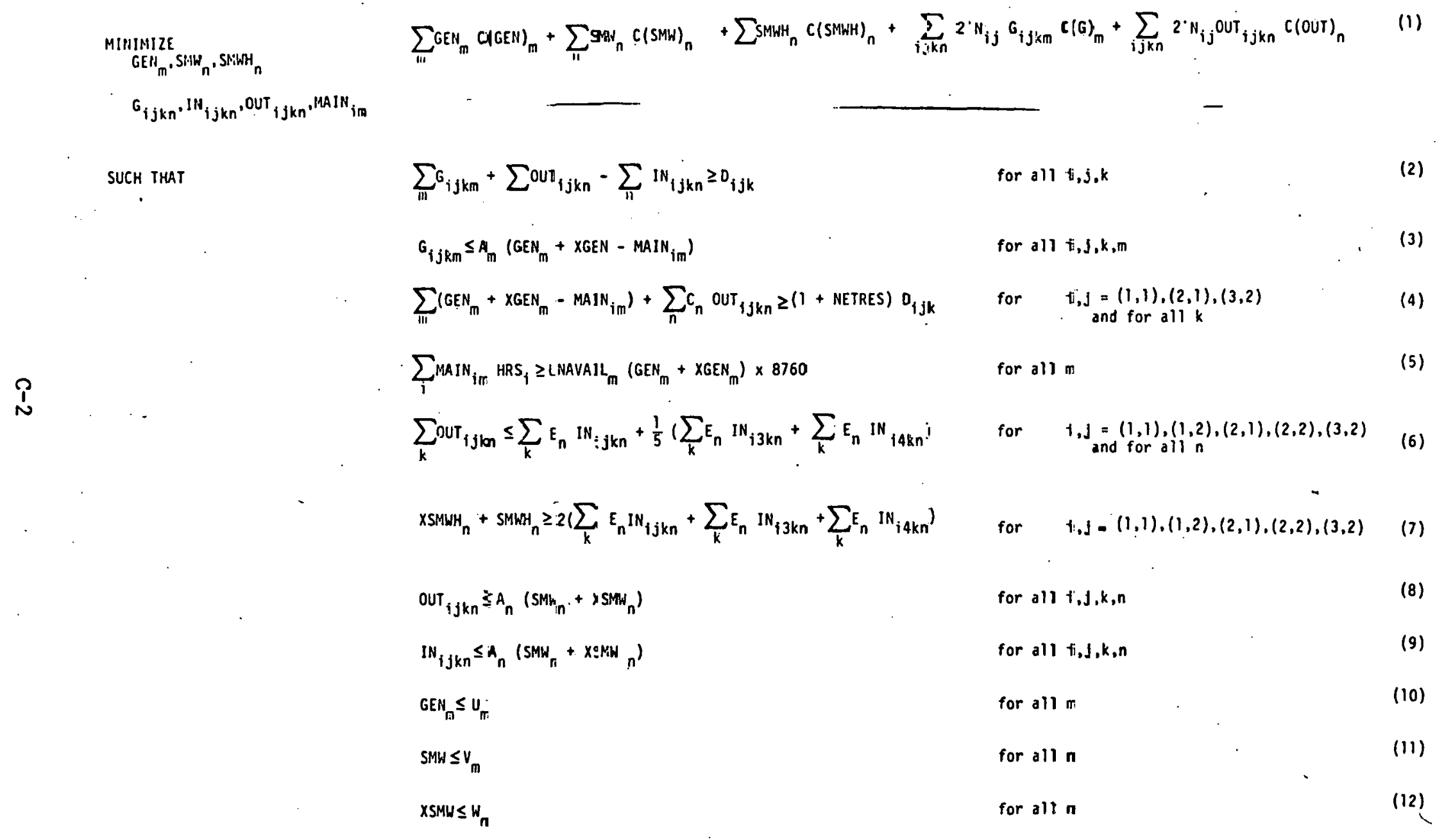




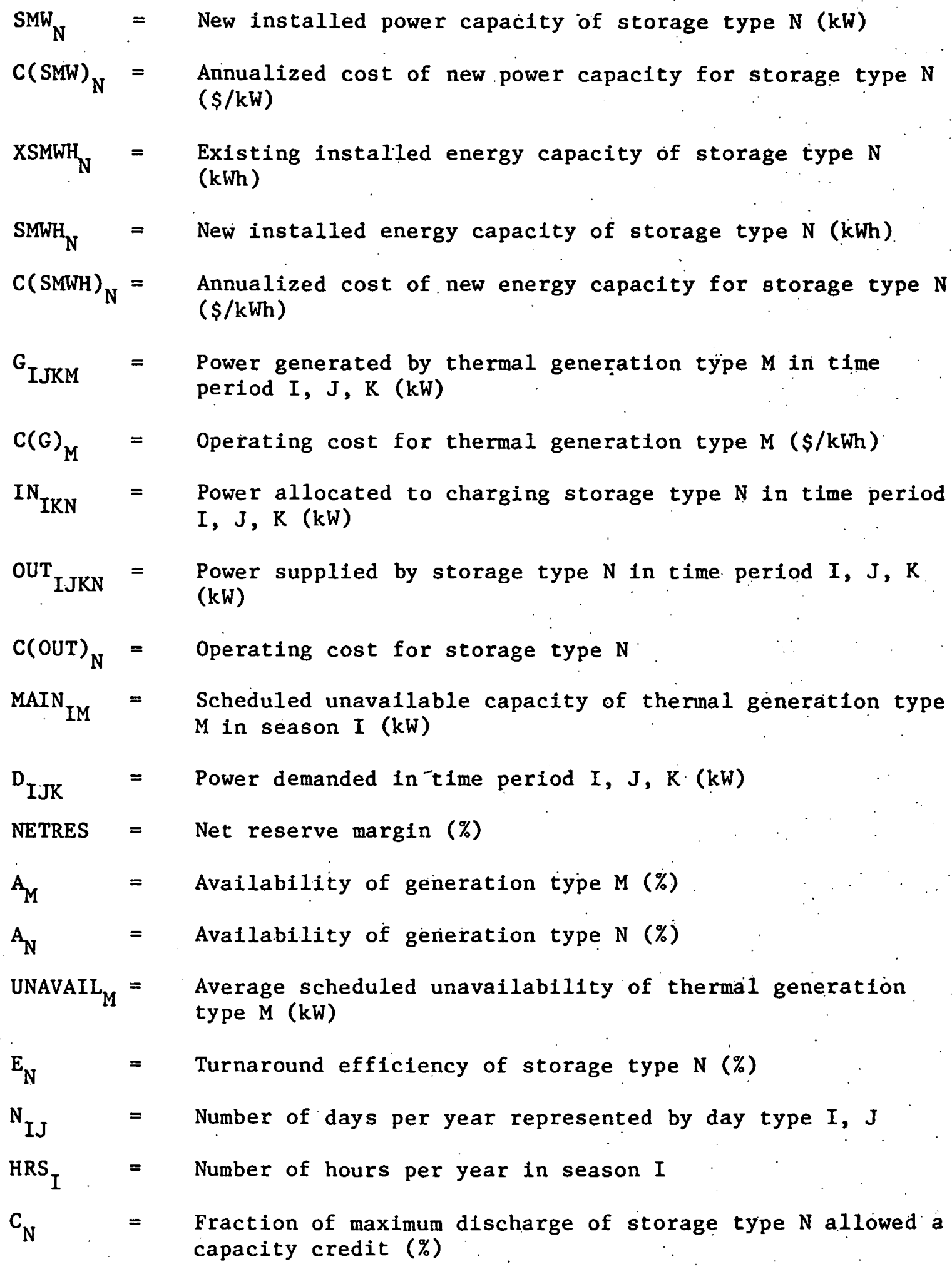




$$
\begin{aligned}
U_{N} & =\begin{array}{l}
\text { Maximum limit of new capacity of thermal generation type } \\
M(\mathrm{~kW})
\end{array} \\
\mathrm{V}_{\mathrm{N}} & =\begin{array}{l}
\text { Maximum limit of new power capacity of storage type } N \\
(\mathrm{~kW})
\end{array} \\
W_{N} & =\begin{array}{l}
\text { Maximum limit of new energy capacity of storage type } N \\
(\mathrm{kWh})
\end{array}
\end{aligned}
$$

The indexes of model variables are

$$
\begin{aligned}
& I=\text { Season Index } \\
& 1 \text { Winter . } \\
& 2 \text { Summer } \\
& 3 \text { Fa11/Spring } \\
& \mathrm{J}=\text { Day Type Index 1. Peak Weekday } \\
& 2 \text { i'ypiral Weekday } \\
& 3 \text { Saturday } \\
& 4 \text { Sunday } \\
& \mathrm{K}=\mathrm{Time} \text { Period Index (two-hour) } \mathrm{k}=1,2, \ldots, 12 \\
& M=\text { Thermal Generation Type Index } 1011 \text { Combustion Turbine } \\
& 2 \text { Coal } \\
& 3 \text { Nuclear } \\
& 4 \text { Steam-0il } \\
& \mathrm{N}=\text { Storage Type Index } \\
& 1 \text { Advanced Batteries } \\
& 2 \text { Inderground Pumped } \\
& \text { Hydro } \\
& 3 \text { Compressed A1 } r \\
& 4 \text { Conventional Pumped } \\
& \text { Hydro }
\end{aligned}
$$

The interpretation of the mathematical relations in Table $\mathrm{C}-1$ are as follows (each number refers to its corresponding numbered relation on the table):

1. Minimize the annualized cost of new power capacity (thermal plus storage) plus the annulized cost of new energy capacity (storage) plus total operating costs. 
2. The total power supplied by all technologies (thermal plus storage) minus the power allocated to charging storage devices is greater than or equal to the power demanded in each time period.

3. The power generated by each thermal generation technology is less than or equal to the available capacity of that type in each time period. Available capacity equals in-service capacity (installed capacity corrected for units on maintenance) adjusted for unscheduled outages.

4. The total in-service thermal generation capacity plus the total amount of power supplied by storage devices times a capacity credit coefficient for each device is greater than or equal to the power demanded plus a reserve margin for each time period in each of the seasonal peak day types.

5. Total scheduled maintenance for each thermal generation technology is greater than or equal to the scheduled maintenance required for that technology.

6. The total energy supplied by each storage technology in one weekday is less than or equal to the total amount of energy stored in that day times the turnaround efficiency of that technology plus one-fifth the amount of energy stored on the corresponding weekend times the efficiency (weekdays only since the model allows no weekend discharging).

7. The total. energy capacity of each storage technology is greater than or equal to the total amount of energy stored on each weekday times the turnaround efficiency of that technology plus the total amount of energy stored on the corresponding weekend times the efficiency (weekdays only).

8. The power allocated to charging each storage technology in each time period is less than or equal to the available capacity of that technology.

9. The power supplied by each storage technology in each time period is less than or equal to the available capacity of that technology (weekends only).

10. through 12 .

The amount of new energy and/or power capacity for each generation type is less than some value. (This is an optional constraint used to account for such things as limited site availability or a desire to maintain a predetermined mix of technology types.) 


\section{THIS PAGE}

WAS INTENTIONALLY

LEFT BLANK 


\section{Appendix D}

DEMAND MODEL DATA AND DEFINITIONS OF END-USE TECHNOLOGIES

This appendix contains the complete set of demand model data for the North Central and South Central regions. Sources of the data are given along with a description of the assumptions that define specific technologies.

DAIIA SOURCES

1. Original market size is based on Referece [4]. North Central Region is a combination of East North Central and West North Central census regions. South Central Region is a combination of East South Central and West South Central census regions. (See Figure D-1.)

2. Growth rates of residential and commercial sectors are based on national averages estimated by Oak Ridge and used in computer runs [6] and [13].

$$
\begin{aligned}
& \text { Residential - } 1.6 \\
& \text { Commercial }-2.8
\end{aligned}
$$

Regional rates are determined by multiplying by regional ratios from [4]. National average growth rate is assumed to be 2.5 with North Central 15\% smaller and South Central 10\% larger. Growth rate in transportation is taken from [4].

3. Original market shares are taken from [4].

4. Installation shares are taken as national averages from [6] and [3].

5. Efficiencies are taken from [4].

6. Fraction electric is based on Reference [4] and specific assumptions are discussed in Appendix E.

7. Service life is taken from [6] and [13].

8. Peak-to-normal ratios are taken from Reference [2]. 


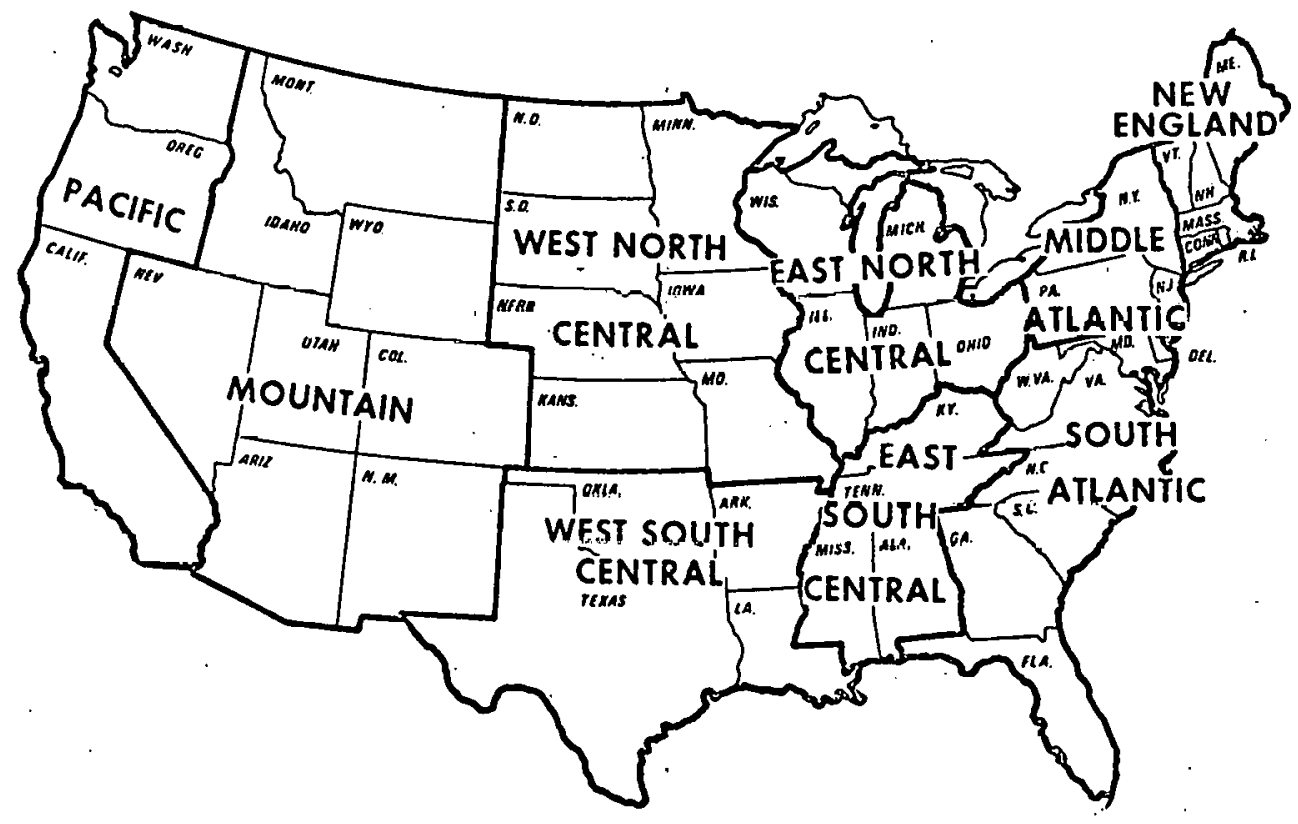

Figure D-1. Regional Breakdown of the Contiguous United States (based on census region boundaries) 
9. Weekend-to-weekday ratios are based on data from References [3], [7], and [8].

10. The seasonal splits are based on monthly heating- and coolingdegree-day data for Detroit, Michigan, and Pine Bluff, Arkansas [9]. Summer is defined as the four-month period from June through September. Winter is three months: December, January, and February.

11. "Replaced by" (conversion) fractions are assumed to be identity matrices (i.e., no conversions for ease of exposition).

12. Load shapes are taken from Reference [14] except space heat, which is from unpublished data of the Load Research Committee of AEIC, and the electric car load shape, which is hypothetical.

\section{DEFINITIONS OF END-USE TECHNOLOGIES}

The end-use technologies in this model are defined by the following data elements:

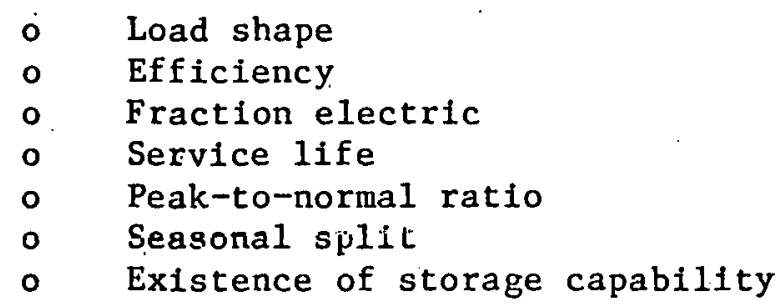

A11 of the data elements by technology are contained in Tables D-1 and D-2 at the end of this appendix. Specific assumptions concerning technologies are described in the following paragraphs.

\section{Space Heat}

Gas/0i1 Furnace. Fraction electric equals .03, based on estimate of energy consumption by furnace fans compared to total furnace energy consumption, Reference [15].

Electric Heat Pump. Efficiency equals 1.5, except on peak days assume efficiency equals 1.0 for backup electric. Result is a peak-to-normal ratio 1.5 times the peak-to-normal ratio for electric resistance. 
Solar: Fraction electric equals .5. Solar systems are assumed to be sized to provide $50 \%$ of space heat and $90 \%$ of water heat requirement [16]. Remainder is electric backup with standard space heat load shape.

Peak-to-normal ratio is assumed to be 1.0 , since days of low insolation are typically not peak cold days.

Resistance with Storage. Customer storage model applied.

Dual-fueled. Heat Pump. Fossil fuel assumed to be used to level electric energy use between winter and fall/spring and between peak and normal days. This makes peak-to-normal ratio equal to 1.0 , and seasonal split proportional to number of days in season $(.37, .00, .63)$. Fraction electric is computed from seasonal split of conventional resistance.

Dual-fueled Heat Pump with Storage. Customer storage model applied.

Water Heat

Solar. Assumed to be part of space heating system described in the previous paragraphs.

Controllable. Customer storage model applied.

\section{Alr Cunditioning}

Room Air Conditioning. Load shapè distincl from ceritral, as shown in Appendix E: Fraction electric equals .32 [4], since room air conditioners are typically used to cool only parts of a residence at any one time.

Heat Pump. Assumed to have same cooling characteristics as central.

Central Alr Conditioning with Storage. Customer storage model applied.

\section{Industrial}

Managed Electric. Customer storage/load management model applied. 
Interruptible. Interruptible load is assumed to be chopped of summer or winter peak day (or both) for a maximum of four hours. Only the annual peak day is chopped unless seasons are evenly balanced.

Transportation (Electric Car)

Efficiency based on electricity consumption of $.5 \mathrm{kWh} / \mathrm{mile}$ and gasoline efficiency of .2. Load shape is hypothetical. 
Table D-1

BASE CASE DATA - WORTH CENTRAL REGICN

PAGE 1

END USES AND TECHNOLOGIES

RESIDENTIAL SPACE HEAT

\section{NO APPLI AIC}

GASIOIL FURDACE

ELECTRIC RESISTENCE

ELECTRIC HEAT PUMP

\section{SOLAR}

RESISTENCE W/STORACE DUAL EUELED HEAT PUMP

RESIDENTIAL WATER HEAT

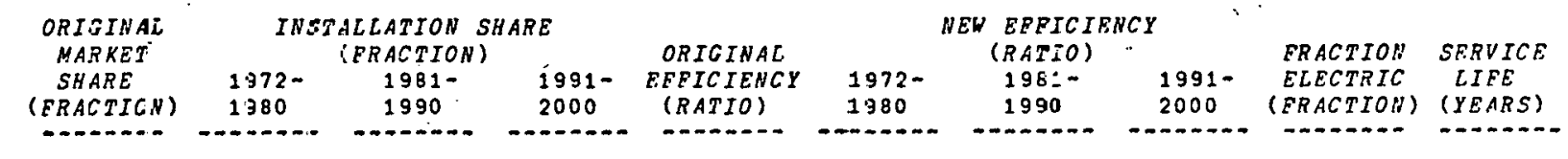
IIO APPLIANCE.

CAS

ELEC

SOLAR
CONTROLLABLE ELECTRIC

BESIDENTIAL AIR CONDITIONING

$$
\text { NO APPLIANCE }
$$

GAS

ELECTRIC CENTRAL

ELECTRIC ROOM

ELECTRIC HEAT PUMP

RESIDENTIAL COOKING

NO APPLIANCE

CAS
ELECTRIC

RESIDENTIAL OTHER

NO APRLIANCE

ELECTRIC

0.07
0.03
0.00

0.00

0.00

0.00

0.00

0.00
0.83
0.17

0.83
0.17

0.00

0.00

0.65

0.65

0.12

0.23

0.00

0.00

0.97
0.03

0.03

0.00

0.00

0.00

0.00
6.00

0.00
0.50
0.50
0.00
0.00
0.00
0.00
0.00

0.00

0.83

0.17

0.00

0.55

0.55
0.00

0.12

0.23

0.00 .
0.00 .

0.00

0.00
0.60
0.40

0.00

0.00
0.60
0.40

0.40

0.00

0.00

1.00

0.00

0.00

0.50

0.50

0.00

0.00

0.00

0.00

0.45

1.50

1.00

1.50
1.50

0.00

0.00

0.00
0.54
0.46

0.54
0.46

0.46
0.00

0.00

0.46
0.00

0.00

1.00
1.00
1.00

1.00
1.00

1.00

1.00

0.20

0.00

1.00
1.00

1.00
2.50

2.00

2.50
2.50

0.00

1.00

0.45
1.00

1.50

1.00

1.00

1.50
1.50

1.00

1.00
1.00
1.00
1.00

1.00
1.00

1.00

1.00

2.50
2.30

2.00
2.50

2.50

1.02

0.55

1.130

1.50
1.00

1.00
1.00

1.00
1.50
1.50

1.50
1.50

1. 00

1.00

1.00

1.00

1.00

1.00

2.50

2.00
2.50

2.50 .

1.00

0.45
1.00

1.00
1.50

1.50
1.00
1.00

1.00

1.50
1.50

1.00

1.00
1.00

1.00
1.00

1.00

0.00

0.03

1.00

1.00

0.50

1.00
0.73

0.73

0.00

0.00

1.00
0.10

$1.00 \quad 1.00$

1.00

1.00

2.50

2.00
2.50

2.50

0.00

0.00

1.00
0.32

1.32
1.00

1.00

$1.00^{\circ} \quad 1.00$

1.00

0.0

1.00
0.45
1.00

0.45
1.00

1.00
1.00

0.45

0.00
0.00

1.00

1.00
1.00

1.00
1.00

1.00
1.00

0.00
1.00

10
10 
Táble $D-1$, continued

BASE CASE DATA - NORTH CENTRAL RFGTON

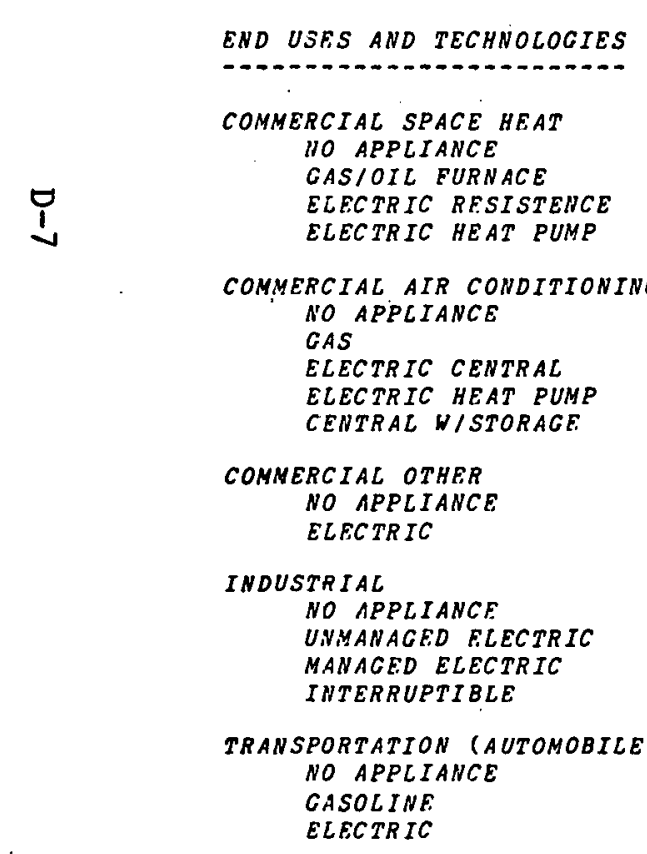

\begin{tabular}{|c|c|c|c|c|c|c|c|c|c|}
\hline \multirow{3}{*}{$\begin{array}{c}\text { ORIGINAL } \\
\text { MARKFT } \\
\text { SHARE } \\
\text { (RRACTION) } \\
\text { (A. }\end{array}$} & \multicolumn{3}{|c|}{ INSTALLATION SHARE } & \multicolumn{6}{|c|}{ NFW EEFICIENCY } \\
\hline & $\begin{array}{l}1972- \\
1980\end{array}$ & $\begin{array}{l}1981- \\
1990\end{array}$ & $\begin{array}{l}1991- \\
2000\end{array}$ & $\begin{array}{l}\text { EFEICIENCY } \\
(\text { RATIO) }\end{array}$ & $\begin{array}{l}1972 . \\
1980\end{array}$ & $\begin{array}{l}1981- \\
1990\end{array}$ & $\begin{array}{l}1991- \\
2000\end{array}$ & $\begin{array}{c}\text { ELECTRIC } \\
\text { (FRACTION) }\end{array}$ & $\begin{array}{c}\text { DIFE } \\
\text { (YEARS) }\end{array}$ \\
\hline & $\cdots$ & $\cdots+\cdots$ & -..n-nan & $\cdots-\cdots$ & $\infty-\infty n-\infty$ & $\cdots+\cdots$ & $\operatorname{logn-\infty }$ & 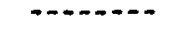 & \\
\hline $\begin{array}{l}0.00 \\
1.00 \\
0.00 \\
0.00\end{array}$ & $\begin{array}{l}0.00 \\
1.00 \\
0.00 \\
0.00\end{array}$ & $\begin{array}{l}0.00 \\
0.94 \\
0.06 \\
0.00\end{array}$ & $\begin{array}{l}0.00 \\
0.94 \\
0.06 \\
0.00\end{array}$ & $\begin{array}{l}1.00 \\
1.00 \\
1.00 \\
1.50\end{array}$ & $\begin{array}{l}1.00 \\
0.54 \\
1.00 \\
1.50\end{array}$ & $\begin{array}{l}1.00 \\
0.54 \\
1.00 \\
1.50\end{array}$ & $\begin{array}{l}1.00 \\
0.54 \\
1.00 \\
1.50\end{array}$ & $\begin{array}{l}0.00 \\
0.03 \\
1.00 \\
1.00\end{array}$ & $\begin{array}{l}15 \\
15 \\
15 \\
15\end{array}$ \\
\hline $\begin{array}{l}0.50 \\
0.05 \\
0.45 \\
0.00 \\
0.00\end{array}$ & $\begin{array}{l}0.50 \\
0.05 \\
0.45 \\
0.00 \\
0.00\end{array}$ & $\begin{array}{l}0.10 \\
0.00 \\
0.90 \\
0.00 \\
0.00\end{array}$ & $\begin{array}{l}0.10 \\
0.00 \\
0.90 \\
0.00 \\
0.00\end{array}$ & $\begin{array}{l}1.00 \\
1.00 \\
3.00 \\
3.00 \\
3.00\end{array}$ & $\begin{array}{l}1.00 \\
1.00 \\
3.00 \\
3.00 \\
3.00\end{array}$ & $\begin{array}{l}1.00 \\
1.00 \\
3.00 \\
3.00 \\
3.00\end{array}$ & $\begin{array}{l}1.00 \\
1.00 \\
3.00 \\
3.00 \\
3.00\end{array}$ & $\begin{array}{l}0.00 \\
0.00 \\
1.00 \\
1.00 \\
1.00\end{array}$ & $\begin{array}{l}10 \\
10 \\
10 \\
10 \\
10\end{array}$ \\
\hline $\begin{array}{l}0.00 \\
1.00\end{array}$ & $\begin{array}{l}0.00 \\
1.00\end{array}$ & $\begin{array}{l}0.00 \\
1.00\end{array}$ & $\begin{array}{l}0.00 \\
1.00\end{array}$ & $\begin{array}{l}1.00 \\
1.00\end{array}$ & $\begin{array}{l}1.00 \\
1.00\end{array}$ & $\begin{array}{l}1.00 \\
1.00\end{array}$ & $\begin{array}{l}1.00 \\
1.00\end{array}$ & $\begin{array}{l}0.00 \\
1.00\end{array}$ & $\begin{array}{l}10 \\
10\end{array}$ \\
\hline $\begin{array}{l}0.00 \\
1.00 \\
0.00 \\
0.00\end{array}$ & $\begin{array}{l}0.00 \\
1.00 \\
0.00 \\
0.00\end{array}$ & $\begin{array}{l}0.00 \\
1.00 \\
0.00 \\
0.00\end{array}$ & $\begin{array}{l}0.00 \\
1.00 \\
0.00 \\
0.00\end{array}$ & $\begin{array}{l}1.00 \\
1.00 \\
1.00 \\
1.00\end{array}$ & $\begin{array}{l}1.00 \\
1.00 \\
1.00 \\
1.00\end{array}$ & $\begin{array}{l}1.00 \\
1.00 \\
1.00 \\
1.00\end{array}$ & $\begin{array}{l}1.00 \\
1.00 \\
1.00 \\
1.00\end{array}$ & $\begin{array}{l}0.00 \\
1.00 \\
1.00 \\
1.00\end{array}$ & $\begin{array}{l}10 \\
10 \\
10 \\
10\end{array}$ \\
\hline $\begin{array}{l}0.00 \\
1.00 \\
0.00\end{array}$ & $\begin{array}{l}0.00 \\
1.00 \\
0.00\end{array}$ & $\begin{array}{l}0.00 \\
1.00 \\
0.00\end{array}$ & $\begin{array}{l}0.00 \\
1.00 \\
0.00\end{array}$ & $\begin{array}{l}1.00 \\
0.20 \\
1.00\end{array}$ & $\begin{array}{l}1.00 \\
0.20 \\
1.00\end{array}$ & $\begin{array}{l}1.00 \\
0.20 \\
1.00\end{array}$ & $\begin{array}{l}1.00 \\
0.20 \\
1.00\end{array}$ & $\begin{array}{l}0.00 \\
0.00 \\
1.00\end{array}$ & $\begin{array}{l}5 \\
5 \\
5\end{array}$ \\
\hline
\end{tabular}


Table D-1, continued

BASE CASE DATA - NORTH CENTRAL REGION

PAGE 3

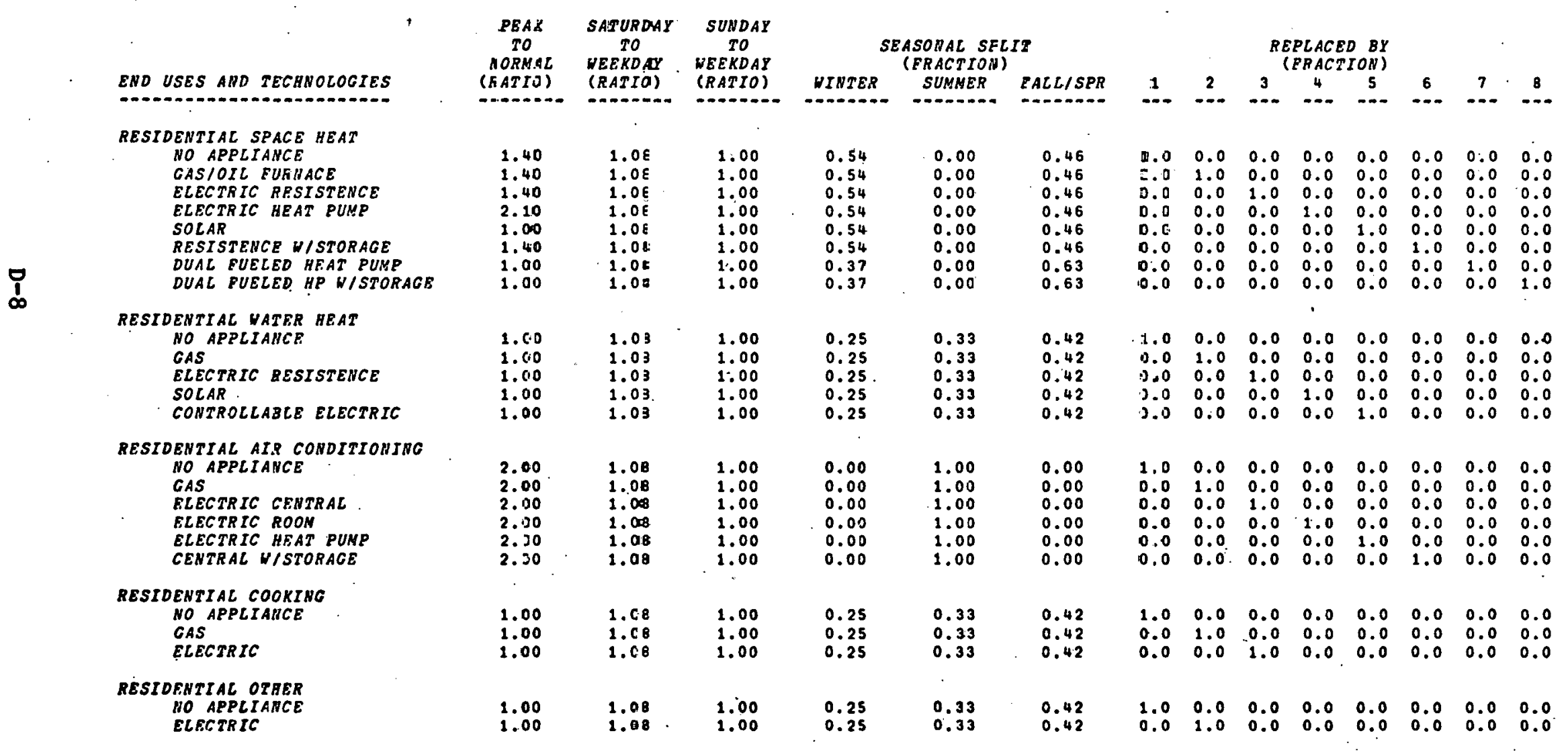


Table D-1, continued

BASE CASE DATA - NORTH CENTRAL REGION

END USFS AND TECHNOLOGIES

COMMERCIAL SPACE HEAI

NO APPLIANCE

ELECTRIC RESISTENCE

ELECTRIC RESISTENCE

COMMERCIAL AIR COHDITIONING

$$
\text { NO APPLIANCE }
$$$$
\text { NAS }
$$

ELECTRTC CENTRAL

ELECTRIC HEAT PUMP

CENTRAL WISTORAGE

COMMERCIAL OTHER

NO APPLIANCE

ELECTRIC

\section{INDUSTRIAL}

O APPLIANCE

UNMANAGED ELECTRIC

MANAGED ELECTRIC

INTERR UPT I BLE

TRANSPORTATION (AUTOMOBILE) NO APPLIANCE

GASOLINE

\section{PEAK
TO
NORMAL
(RATIO) \\ $n-\infty-0-0$}

SATURDAY SUNDAY

$\begin{array}{cc}\text { TO } & \text { TO } \\ \text { WEEKDAY } & \text { WFEKDAY }\end{array}$

SFASONAL SPLIT

RATIO)

(RATIO)

REPLACED BY

1.40

0.93

0.51
0.51
0.51

0.54
0.54

SUMMER BACLISPR

12

(ERACTION)

$1.40 \quad 0.93$

0.00

0.00

0.00

0.46

$2.10 \quad 0.93$

0.51

0.54

2.00

0.93

0.51

0.00

1.00

1.00

$0.93 \quad 0.51 \quad 0.00$

0.93

0.51 .

0.00

0.00

1.00
1.00

1.00

2.00
2.00

0.93

0.51

1.00
1.00

0.93
0.93

0.51
0.51

0.25
0.25

0.33
0.33

0.70

0.70

0.50

0.50

0.50
0.50
0.50

0.25

0.25

1.00
1.00

0.70

0.50

0.25

0.33
0.33

0.33

0.33

0.25

0.25
0.25

0.33

0.33
0.33

$\begin{array}{llllllll}1.0 & 0.0 & 0.0 & 0.0 & 0.0 & 0.0 & 0.0 & 0.0\end{array}$ $\begin{array}{llllllll}0.0 & 1.0 & 0.0 & 0.0 & 0.0 & 0.0 & 0.0 & 0.0\end{array}$ $\begin{array}{llllllll}0.0 & 0.0 & 0.0 & 1.0 & 0.0 & 0.0 & 0.0 & 0.0\end{array}$

0.00

0.00

0.00

0.00

$\begin{array}{llllllll}1.0 & 0.0 & 0.0 & 0.0 & 0.0 & 0.0 & 0.0 & 0.0\end{array}$ $\begin{array}{llllllll}0.0 & 1.0 & 0.0 & 0.0 & 0.0 & 0.0 & 0.0 & 0.0\end{array}$ $\begin{array}{llllllll}0.0 & 0.0 & 1.0 & 0.0 & 0.0 & 0.0 & 0.0 & 0.0 \\ 0.0 & 0.0 & 0.0 & 1.0 & 0.0 & 0.0 & 0.0 & 0.0\end{array}$ $\begin{array}{lllllllll}0.0 & 0.0 & 0.0 & 0.0 & 1.0 & 0.0 & 0.0 & 0.0\end{array}$

$\begin{array}{ll}1.00 & 1.00 \\ 1.00 & 1.00 \\ 1.00 & 1.00\end{array}$


Table D-1, continued

END USES AND TECHMOLOGIES

RESIDENTIAL SPACE HEAT NO APPLI.ANCE

GASIOIL FURNACE

ELECTRIC RESISTEHCE

SOLAR

RESISTENCE WISTORAGE

DUAL FUELED HEAT PUMP

DUAL FUELED HP WISTORAGE

RESIDENTIAL WATER HEAT

NO APPLIANCE

C'AS

ELECTRIC RESISTENCE

SOLAR

CONTROLLABLE ELECTRIC

RESTDENTIAL AIR CONDITIONING

NO APPLIANCE

ELECTRIC CEUTRAL

ELECTRIC ROOM

ELECTRIC HEAT PUNP

CENTRAL W/STORAGE

RESIDENTIAL COOKING

NO APPLIANCE

GAS

ELECTRIC

RESIDENTIAL OTHER

NO APPLIANCE
STANDARD LOAD SHAPES

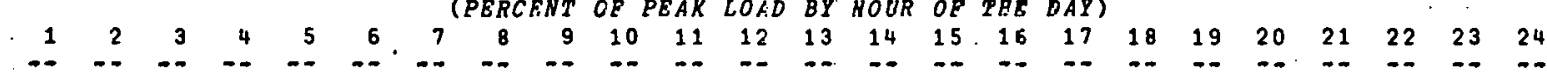

$100100100100 \quad 100100100100 \quad 100 \quad 100 \quad 100 \quad 100 \quad 100100 \quad 10010) \quad 100100100100100100100100$

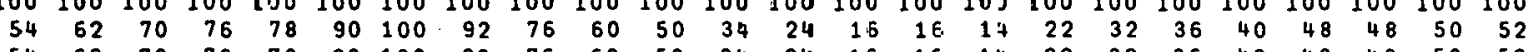
$\begin{array}{rrrrrrrrrrrrrrrrrrrrrrrr}54 & 62 & 70 & 76 & 78 & 90 & 100 & 92 & 76 & 60 & 50 & 34 & 24 & 16 & 16 & 14 & 22 & 32 & 36 & 40 & 48 & 48 & 50 & 52 \\ 75 & 75 & 80 & 84 & 86 & 88 & 93 & 100 & 93 & 84 & 79 & 79 & 76 & 68 & 64 & 59 & 73 & 73 & 74 & 78 & 81 & 75 & 75 & 77\end{array}$

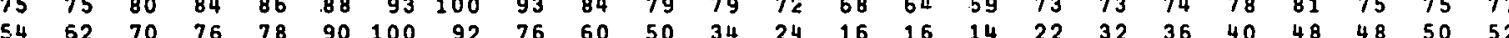

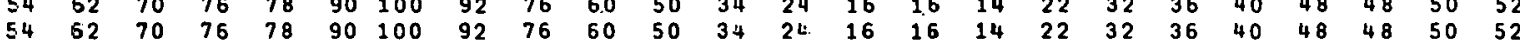
$\begin{array}{lllllllllllllllllllllllll}75 & 75 & 80 & 84 & 86 & 88 & 93 & 100 & 93 & 84 & 79 & 79 & 72 & 68 & 64 & 6: 9 & 73 & 73 & 74 & 78 & 81 & 75 & 75 & 77\end{array}$ $\begin{array}{llllllllllllllllllllllll}75 & 75 & 80 & 84 & 86 & 88 & 93 & 100 & 93 & 84 & 79 & 79 & 72 & 68 & 64 & 69 & 73 & 73 & 74 & 78 & 81 & 75 & 75 & 77\end{array}$

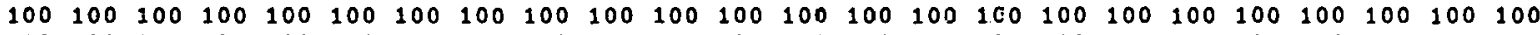
100100100100100100100100100100100100100100100100100100100100100100100100 $\begin{array}{llllllllllllllllllllllll}59 & 51 & 44 & 38 & 29 & 32 & 46 & 64 & 71 & 68 & 69 & 72 & 75 & 73 & 73 & 71 & 72 & 80 & 88 & 100 & 91 & 81 & 72 & 66\end{array}$ $\begin{array}{llllllllllllllllllllllll}59 & 51 & 44 & 38 & 29 & 32 & 46 & 64 & 71 & 68 & 69 & 72 & 75 & 73 & 73 & 71 & 72 & 80 & 88 & 100 & 91 & 81 & 72 & 66 \\ 5 & 51 & 44 & 38 & 29 & 32 & 46 & 64 & 71 & 68 & 59 & 72 & 75 & 73 & 73 & 71 & 72 & 80 & 88 & 100 & 91 & 81 & 72 & 66\end{array}$

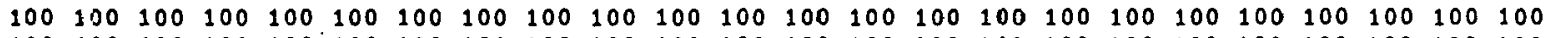

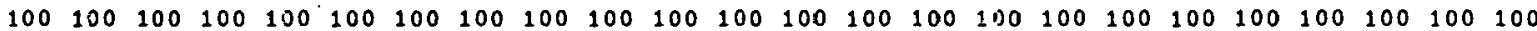
$\begin{array}{llllllllllllllllllllllll}18 & 10 & 9 & 7 & 5 & 6 & 12 & 12 & 21 & 28 & 36 & 57 & 66 & 80 & 89 & 34 & 100 & 96 & 96 & 84 & 64 & 51 & 46 & 26\end{array}$ $\begin{array}{llllllllllllllllllllllll}86 & 83 & 80 & 76 & 73 & 69 & 61 & 59 & 54 & 55 & 56 & 60 & 70 & 77 & 83 & 36 & 89 & 92 & 92 & 94 & 95 & 100 & 97 & 91\end{array}$

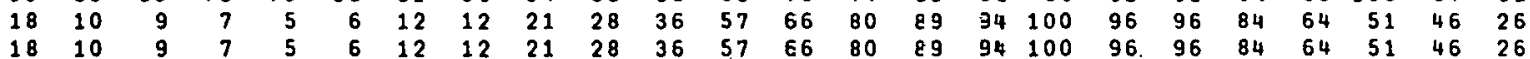

$100 \quad 100 \quad 100 \quad 100 \quad 100 \quad 100 \quad 100 \quad 100 \quad 100 \quad 100 \quad 100 \quad 100 \quad 100 \quad 100 \quad 100 \quad 10 \cdot 5 \quad 100 \quad 100 \quad 100100 \quad 100 \quad 100 \quad 100 \quad 100$

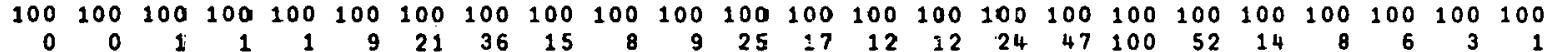

$\begin{array}{rrrrrrrrrrrrrrrrrrrrrrrrrrrrr}100 & 100 & 106 & 10 C & 100 & 100 & 100 & 100 & 100 & 100 & 100 & 10 C & 100 & 100 & 100 & 100 & 100 & 100 & 100 & 100 & 100 & 100 & 100 & 100 \\ 25 & 17 & 10 & 5 & 12 & 25 & 44 & 58 & 47 & 45 & 50 & 45 & 46 & 41 & 45 & 48 & 56 & 74 & 95 & 100 & 96 & 94 & 69 & 45\end{array}$ 
Table $[-1$, continued

BASE CASE DATA - NORTH CENTRAL REOTON

END USES AND TECHNOLOGIES

NO APPLIANCE

ELECTRIC RESISTENCE

COMMERCIAL AIR CONDTTIOHING

NO APPLIANCE

GAS

ELE־TRIC CENTRAL

ELECTEIC HEAT PUMP

CENTRAL W'/STORAGE

COMMERCIAL OTHER

NO APPLIAUCE

ELECTRIC

INDUSTRIAL

O APPLIANCE

UNMAIIAGED ELECTRIC

HANACFD ELECTRIC

INTERRUPTI $B L E$

TRANSPORTATION (AUTONOEILE) NO $A P P L I A N C E$

GASGLINE

STANDARD LOAD SHAPES

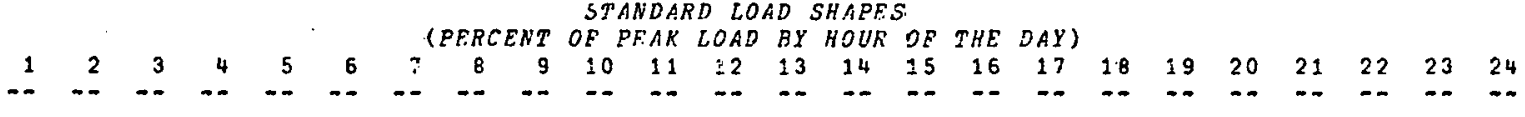

$100100100.100100100100 \quad 100100100100100100100120100100100100100100100100100$

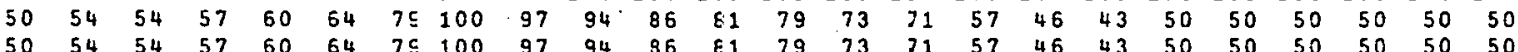

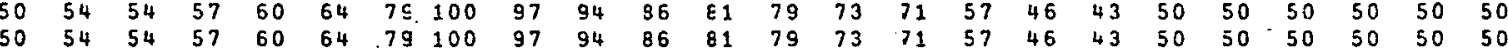

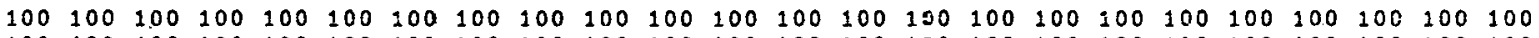
$100100100100100100100100100 \quad 100100100100100 \quad 100100100 \leq 00100100100100100100$ $\begin{array}{llllllllllllllllllllllll}5 & 5 & 5 & 5 & 5 & 1-2 & 31 & 50 & 66 & 73 & 80 & 88 & 93 & 98 & 99 & 100 & 72 & 45 & 32 & 18 & 15 & 12 & 8 & 5 \\ 5 & 5 & 5 & 5 & 5 & 12 & 31 & 50 & 66 & 73 & 80 & 88 & 93 & 98 & 99 & 100 & 72 & 45 & 32 & 18 & 15 & 12 & 8 & 5 \\ 5 & 5 & 5 & 5 & 5 & 12 & 31 & 50 & 66 & 73 & 80 & 88 & 93 & 98 & 99 & 100 & 72 & 45 & 32 & 18 & 15 & 12 & 8 & 5\end{array}$

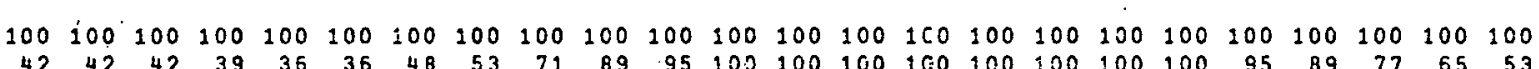
$100 \quad 100 \quad 200 \quad 100 \quad 100100100100 \quad 100 \cdot 100 \quad 100 \quad 100100 \quad 100100 \quad 100 \quad 100100100100 \quad 100 \quad 100100 \quad 100$ $\begin{array}{lllllllllllllllllllllllll}65 & 65 & 65 & 65 & 70 & 75 & 80 & 85 & 92 & 95 & 100 & 97 & 99 & 100 & 100 & 95 & 95 & 90 & 80 & 75 & 70 & 65 & 65 & 65 \\ 65 & 65 & 65 & 55 & 70 & 75 & 80 & 65 & 92 & 95 & 100 & 97 & 99 & 100 & 100 & 95 & 95 & 90 & 80 & 75 & 70 & 65 & 55 & 65\end{array}$ $\begin{array}{llllllllllllllllllllllll}65 & 65 & 65 & 65 & 70 & 75 & 80 & 65 & 92 & 95 & 100 & 97 & 99 & 100 & 100 & 95 & 95 & 90 & 80 & 75 & 70 & 65 & 65 & 65 \\ 65 & 65 & 65 & 65 & 70 & 75 & 80 & 65 & 92 & 95 & 100 & 97 & 99 & 100 & 100 & 95 & 95 & 90 & 60 & 75 & 70 & 65 & 65 & 65\end{array}$

100100100100100100100100100100100100100100100100100100100100100100100100

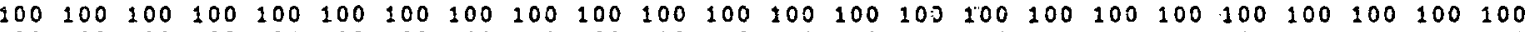

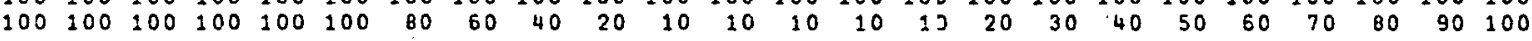


Table D-2

BASE CASE DATA - SOUTH CENTRAL PRGTON

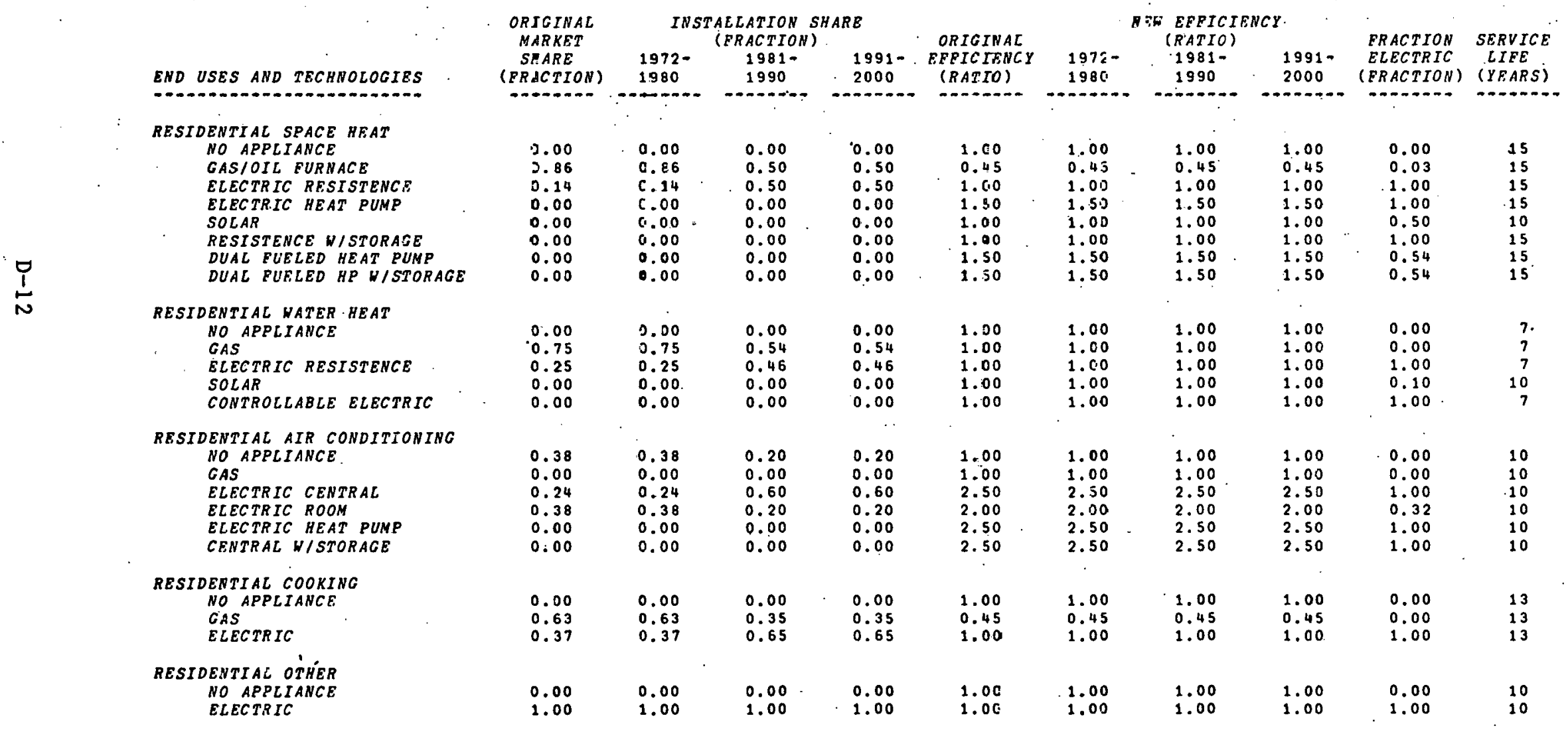


Table D-2, continued

BASE CASE DATA - SOUTH CFNTRAL REGION

END USES AND TECHNOLOGIES

COMMERCIAL SPACE HEAT NO APPLIANCE

GASIOIL FURNACE

ELECTRIC RESISTENCE

ELECTRIC HEAT PUMP

COMMERCIAL AIR CONDITIONING

NO APPLIANCE.

GAS

$\frac{0}{1}$

ELECTRIC CENTRAL

ELECTRIC HEAT PUNP

CENTRAL W/STORAGE

COMMERCIAL OTHER

NO APPLIANCE

INDUSTRIAL

NO APPLIANCE

UNMANACED ELECTRIC

MANAGED ELECTRIC
INTERRUPTIBLE

TRANSPORTATION (AUTOMOBILE)

IO APPLIANCE

GASOLINE
ELECTRIC

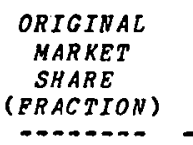

INSTALLATICN SHARE

(FRACTION)

$1972-\quad 1981$

1996

1991 -

2000

FEICIFIC

EFEICIFIIC
(RATIO)

1980

1980

NEW EFFICIFNCY

( $R A T T O)$

$1981-\cdots 1991-$ $2000 \quad($ FRACTION)

FRACTION SERVICE

FLECTRIC LIFE

1990

(YEARS)

$\begin{array}{ll}0.00 & 0.00 \\ 1.00 & 1.00 \\ 0.00 & 0.00 \\ 0.00 & 0.00\end{array}$

0.50

0.50

0.46

.00

0.00

0.00

1.00

\section{$0.0 \mathrm{C}$}

0.00

1.00

1.00

1.00

$\begin{array}{llllllll}0.00 & 0.04 & 0.00 & 1.00 & 1.00 & 1.00 & 1.00 & 0.003 \\ 1.00 & 0.94 & 0.94 & 1.00 & 0.54 & 0.54 & 1.54 & 1.03 \\ 0.00 & 0.06 & 0.06 & 1.00 & 1.00 & 1.00 & 1.00 & 1.00 \\ 0.00 & 0.00 & 0.00 & 1.500 & 1.50 & 1.50 & 1.50 & 1.00\end{array}$

1.00
0.54
1.00

$\begin{array}{llllllll}0.00 & .06 & 0.06 & 1.00 & 1.54 & 0.54 & 0.54 & 0.00 \\ 0.00 & 0.06 & 0.00 & 1.5 .0 & 1.50 & 1.00 & 1.00 & 1.00 \\ 0.00 & 0.00 & 0.00 & & & & 1.50 & 1.00\end{array}$

0.00

0.03

$0.00 \quad 1.50$

0.50

0.04

0.46

0.00

0.05

0.05

1.00

1.00

1.00
1.00

1.00

0.95

0.00

0.95

0.00

3.00

3.00

3.00

3.00

3.00

1.00
3.00

3.00
3.00

0.00

0.00
1.00

0.00

0.00

1.00

1.00

1.00

1.00

1.00

1.00

1.00

0.00

1.00

0.00

1.00

1.00

1.00

0.00
1.00

0.00

0.00
1.00

0.00
1.00

0.00

1.00

1.00

1.00
1.00

1.00
1.00

1.00

1.00
1.00

1.00
1.00

1.00

1.00
1.00

0.00

1.00

0.00

0.00
1.00
0.00

0.00

1.00

0.00

0.00

1.00

0.20
1.00

1.00

0.20

1.00

0.20

1.00

0.20

1.00

0.00

0.00

1.00
15
15

15

1. 
Table D-2, continued

EASE CASE DATA - SOUTH CENTRAL REGIOH

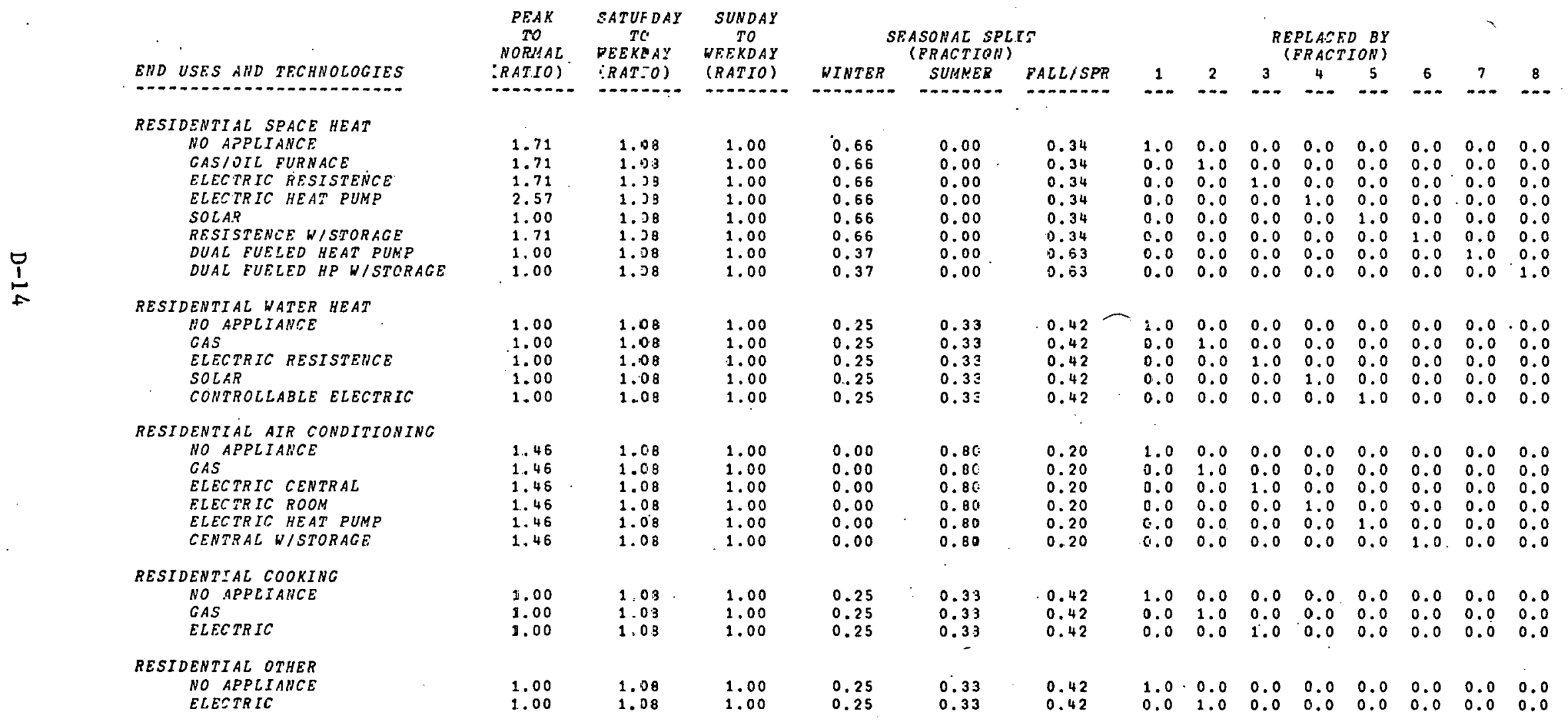


Table D-2, continued

BASE CASE DATA - SOUTH CENTRAL REGION

\section{END USES AND TECHNOLOGIES}

\section{COMNERCIAL SPACE HEAT}

NO APPLIANCE

GASIOIL FURWACE

ELECTRIC HEAT PUMP

COMNERCIAL AIR CONDITTONINO NO APPLIANCE

$\frac{1}{n}$

ELECTRIC CENTRAL

ELEETRIC HEAT

\begin{tabular}{c} 
PEAK \\
TO \\
NORMAL \\
(RATIO) \\
\hline
\end{tabular}

$\begin{array}{cc}\text { SATURDAY } & \text { SUNDAY } \\ \text { TO } & \text { TO } \\ \text { WEERDAY } & \text { WEEKDAY } \\ (\text { RATIO }) & (\text { RATIO) }\end{array}$

(RATIO)

1.71
1.71
1.71
2.57

0.93

0.9

0.93
0.93

0.51

0.51

0.51

1.46

1.46
1.46

COMMERCIAL OTHER

NO APPLIANCE

ELECTRIC

INDUSTRIAL

UNMANAGED ELECTRIC

MALIAGED ELECTRIC

INTERRUPTIBLE

TRANSPORTATION (AUTOMOBILE)

NO APPLIANCE

GASOLINE

CASOLINE

0.93

0.51

0.51

0.51

0.51

0.93

1.00

0.93

0.51

0.51

0.50

1.00

1.00

1.00

0.70

0.70

0.50

0.50

1.00

1.00
1.00
1.00

1.00

1.00

1.00

1.00

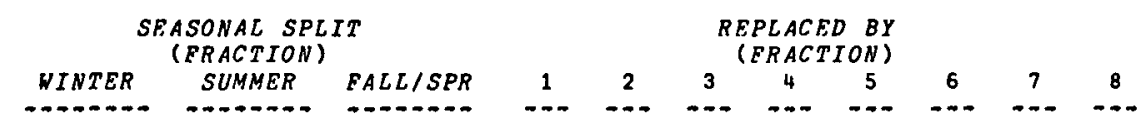

$0.66 \cdot 0.00 \quad 0.34$

$\begin{array}{lllllllll}0.34 & 1.0 & 0.0 & 0.0 & 0.0 & 0.0 & 0.0 & 0.0 & 0.0 \\ 0.34 & 0.0 & 1.0 & 0.0 & 0.0 & 0.0 & 0.0 & 0.0 & 0.0\end{array}$

$\begin{array}{llllllll}1.0 & 1.0 & 0.0 & 0.0 & 0.0 & 0.0 & 0.0 & 0.0\end{array}$

$\begin{array}{lllllllll}0.34 & 0.0 & 0.0 & 0.0 & 1.0 & 0.0 & 0.0 & 0.0 & 0.0\end{array}$

0.25

\subsection{0}

0.00

0.00

0.00

0.80

0.80

0.80

0.80

0.20

0.20

0.20

0.20

0.33

0.42

0.42

0.25

0.25

0.25

0.33
0.33
0.33

0.33

0.42
0.42

0.42
0.42

0.25

0.33

0.25
0.25
0.25

0.33 $\begin{array}{lllllllll}0.0 & 0.0 & 0.0 & 1.0 & 0.0 & 0.0 & 0.0 & 0.0\end{array}$

$\begin{array}{lllllllllll}1.0 & 0.0 & 0.0 & 0.0 & 0.0 & 0.0 & 0.0 & 0.0\end{array}$ $\begin{array}{llllllll}0.0 & 1.0 & 0.0 & 0.0 & 0.0 & 0.0 & 0.0 & 0.0\end{array}$

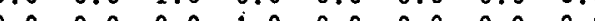
$\begin{array}{llllllll}0.0 & 0.0 & 0.0 & 1.0 & 0.0 & 0.0 & 0.0 & 0.0 \\ 0.0 & 0.0 & 0.0 & 1.0 & 0.0 & 0.0 & 0.0\end{array}$

0.42

0.42

$\begin{array}{llllllll}1.0 & 0.0 & 0.0 & 0.0 & 0.0 & 0.0 & 0.0 & 0.0\end{array}$ $\begin{array}{llllllll}1.0 & 1.0 & 0.0 & 0.0 & 0.0 & 0.0 & 0.0 & 0.0\end{array}$

$\begin{array}{llllllll}1.0 & 0.0 & 0.0 & 0.0 & 0.0 & 0.0 & 0.0 & 0.0\end{array}$ $\begin{array}{llllllll}0.0 & 1.0 & 0.0 & 0.0 & 0.0 & 0.0 & 0.0 & 0.0\end{array}$ $\begin{array}{llllllll}0.0 & 0.0 & 1.0 & 0.0 & 0.0 & 0.0 & 0.0 & 0.0 \\ 0.0 & 0.0 & 0.0 & 1.0 & 0.0 & 0.0 & 0.0 & 0.0\end{array}$

$\begin{array}{llllllll}1.0 & 0.0 & 0.0 & 0.0 & 0.0 & 0.0 & 0.0 & 0.0\end{array}$ $\begin{array}{llllllll}1.0 & 0.0 & 0.0 & 0.0 & 0.0 & 0.0 & 0.0 & 0.0 \\ 0.0 & 1.0 & 0.0 & 0.0 & 0.0 & 0.0 & 0.0 & 0.0\end{array}$

$\begin{array}{lllllllll}0.42 & 0.0 & 0.0 & 1.0 & 0.0 & 0.0 & 0.0 & 0.0 & 0.0\end{array}$ 
Table D-2, continued

BASR CASE DATA - SOUTA CENTRAL REGTON

PAGE 5

EHD USES AND TECANOCOCIES

RESIDENTIAL SPACE HEAT

NO APPLIANCE

GASIOIL EURUACE

ELECTRIC RESISTENCE

FLECTRIC HEAT PUMP

SOLAR

RESISTENCE WISTORAGE

DUAL FUELED HEAT PUMP

$\frac{1}{1}$

RESIDENTIAL WATER HEAT

NO APPLIANCE

ELS

SOLAR

CONTROLLABLE ELECTRIC

RESIDENTIAL AIR CONDITIONING

NO APPLIANCE

GAS

ELECTRIC CENTRAL

ELECTRIC ROOM

ELECTRIC HEAT PUMP

CENTRAL WISTORAGE

RESIOENTIAL COOKING

NO APPL I ANCE

GAS
ELECTRJC

RESIDENTIAL OTHER

NO APPIITANCE

ELECTRIC

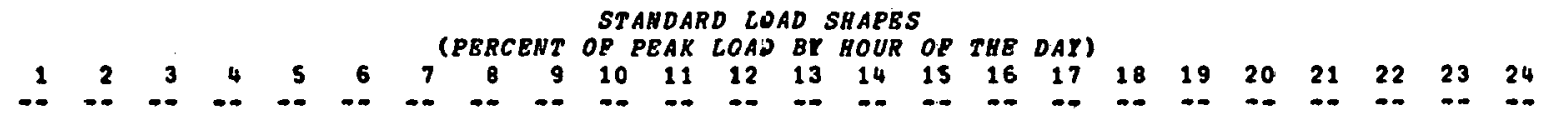

100100100100100100100100100100100100100100100100100100100100100100100100 $\begin{array}{llllllllllllllllllllllll}54 & 62 & 70 & 76 & 78 & 90 & 100 & 92 & 76 & 60 & 50 & 34 & 24 & 16 & 16 & 14 & 22 & 32 & 36 & 40 & 48 & 48 & 50 & 52\end{array}$ $\begin{array}{rrrrrrrrrrrrrrrrrrrrrrrr}54 & 62 & 70 & 76 & 78 & 90 & 100 & 92 & 76 & 60 & 50 & 34 & 24 & 16 & 16 & 14 & 22 & 32 & 36 & 40 & 48 & 48 & 50 & 52 \\ 75 & 75 & 80 & 84 & 86 & 88 & 93 & 100 & 93 & 84 & 79 & 79 & 72 & 68 & 64 & 69 & 73 & 73 & 74 & 78 & 81 & 75 & 75 & 77\end{array}$ $\begin{array}{llllllllllllllllllllllll}54 & 62 & 70 & 75 & 78 & 90.100 & 92 & 76 & 60 & 50 & 34 & 24 & 16 & 16 & 14 & 22 & 32 & 36 & 40 & 48 & 48 & 50 & 52\end{array}$ $\begin{array}{llllllllllllllllllllllll}54 & 62 & 70 & 76 & 78 & 90 & 100 & 92 & 76 & 60 & 50 & 34 & 24 & 16 & 16 & 14 & 22 & 32 & 36 & 40 & 48 & 48 & 50 & 52 \\ 5 & 15 & & 84 & 86 & 80 & 93 & 00 & 93 & 84 & 79 & 79 & 2 & 68 & 64 & 69 & 73 & 73 & 44 & 78 & 81 & 75 & 75 & 72\end{array}$

$\begin{array}{rrrrrrrrrrrrrrrrrrrrrrrrr}54 & 62 & 70 & 76 & 78 & 90 & 100 & 92 & 76 & 60 & 50 & 34 & 24 & 16 & 16 & 14 & 22 & 32 & 36 & 40 & 48 & 48 & 50 & 52 \\ 75 & 75 & 80 & 84 & 86 & 88 & 93 & 100 & 93 & 84 & 79 & 79 & 72 & 68 & 64 & 69 & 73 & 73 & 74 & 78 & 81 & 75 & 75 & 77 \\ 75 & 75 & 80 & 84 & 86 & 88 & 93 & 100 & 93 & 84 & 79 & 79 & 72 & 68 & 64 & 69 & 73 & 73 & 74 & 78 & 81 & 75 & 75 & 77\end{array}$

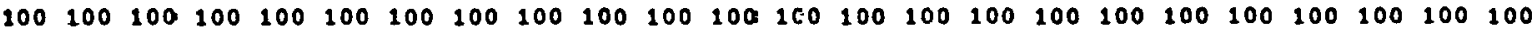

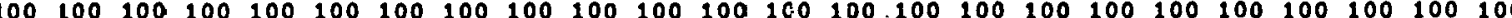

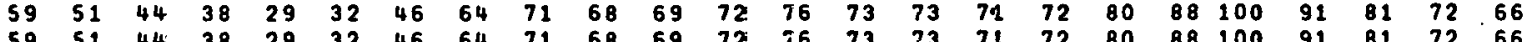
$\begin{array}{lllllllllllllllllllllllll}59 & 51 & 44 & 38 & 29 & 32 & 46 & 64 & 71 & 68 & 69 & 72 & 76 & 73 & 73 & 71 & 72 & 80 & 88 & 100 & 91 & 81 & 72 & 66 \\ 59 & 51 & 44 & 38 & 29 & 32 & 46 & 64 & 71 & 68 & 69 & 72 & 76 & 73 & 73 & 71 & 72 & 80 & 88 & 100 & 91 & 81 & 72 & 66\end{array}$

100100100100100100100100100100100100100100100100100100100100100100100100 $100 \quad 100100100100100100 \quad 100 \quad 100 \quad 100 \quad 100 \quad 100 \quad 100 \quad 100 \quad 100 \quad 100 \quad 100 \quad 100 \quad 100 \quad 100 \quad 100 \quad 100100100$ $\begin{array}{llllllllllllllllllllllll}18 & 10 & g & 7 & 5 & 6 & 12 & 12 & 21 & 28 & 36 & 57 & 66 & 80 & 89 & 94 & 100 & 96 & 96 & 84 & 64 & 51 & 46 & 2.6\end{array}$ $\begin{array}{llllllllllllllllllllllll}86 & 83 & 80 & 76 & 73 & 69 & 61 & 59 & 54 & 55 & 56 & 6 G & 70 & 77 & 83 & 86 & 89 & 92 & 92 & 94 & 95 & 100 & 97 & 91\end{array}$

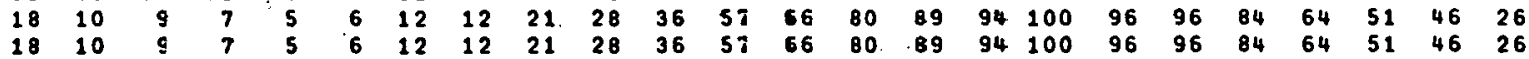

$100100 \quad 100 \quad 100 \quad 100100100100100 \quad 100100100 \quad 100 \quad 100 \quad 100100 \quad 100100100100100100100100$

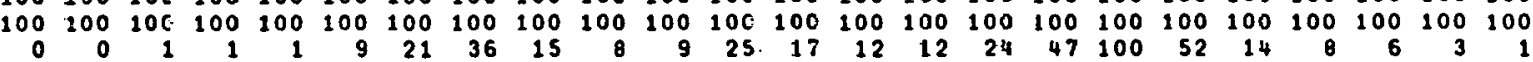
$\begin{array}{rrrrrrrrrrrrrrrrrrrrrrrrrrrrrrr}100 & 100 & 100 & 100 & 100 & 100 & 100 & 100 & 100 & 100 & 100 & 100 & 100 & 100 & 100 & 100 & 100 & 100 & 100 & 100 & 100 & 100 & 100 & 100 \\ 25 & 17 & 10 & 5 & 12 & 25 & 44 & 58 & 47 & 45 & 50 & 49 & 6 & 41 & 45 & 48 & 56 & 74 & 95 & 100 & 96 & 94 & 69 & 45\end{array}$ 
Table D-2, continued

BASE CASE DATA - SOUTH CENTRAL REGION

\section{END USES AND TECHNOLOGIES}

COMMERCIAL SPACE HEAT "IO APPLIANCE ELECTRIC RESISTENCE
ELECTRIC HEAT PUMP

COMMERCIAL AIR CONDITIONING NO APPLL IANCE

ELECTRIC CENTRAL ELECTRIC HEAT PUNP CENTRAL UISTORAGE

CONNERCIAL OTHER NO APPLTANCE ELECTRIC

IRDUSTR IAL UNMANAGED ELECTRIC MANAGED ELECTRIC IUTERR UPTIBLE

TRANSPORTATION (AUTONOBILE) NO APPLIANCE ELECTRIC

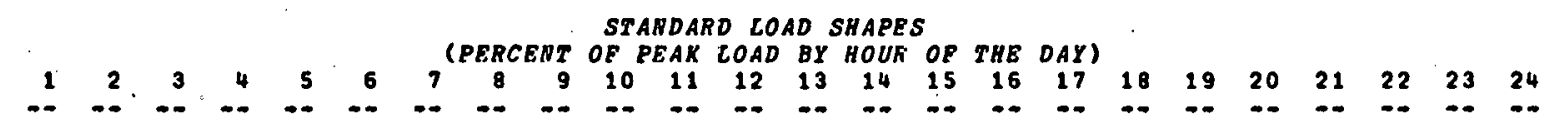

$100100100100100100100 \quad 100100 \quad 100100100100100100100100100100100100100100100$ $\begin{array}{lllllllllllllllllllllllllll}50 & 54 & 54 & 57 & 60 & 64 & 79 & 100 & 97 & 94 & 86 & 81 & 79 & 73 & 71 & 57 & 46 & 43 & 50 & 50 & 50 & 50 & 50 & 50\end{array}$

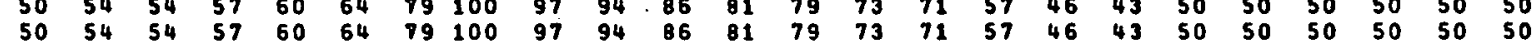

100100100100100100100100100100100100100100100100100100100100100100100100 $100100100100100100100100100 \quad 100100100100100 \quad 100100 \quad 100 \quad 100100100100100100100$ $\begin{array}{llllllllllllllllllllllll}5 & 5 & 5 & 5 & 5 & 12 & 31 & 50 & 66 & 73 & 80 & 88 & 93 & 98 & 99 & 100 & 72 & 45 & 32 & 18 & 15 & 12 & 8 & 5\end{array}$

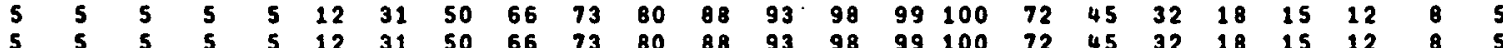

$\begin{array}{llllllllllllllllllllllllll}100 & 100 & 100 & 100 & 100 & 100 & 100 & 100 & 100 & 100 & 100 & 100 & 100 & 100 & 100 & 100 & 100 & 100 & 100 & 100 & 100 & 100 & 100 & 100\end{array}$ $00100100100100100100100100100100100100100100100100100 \cdot 100100100100100100$

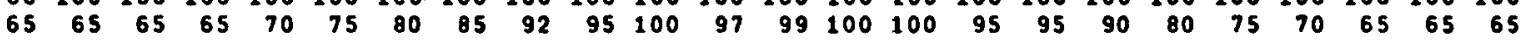

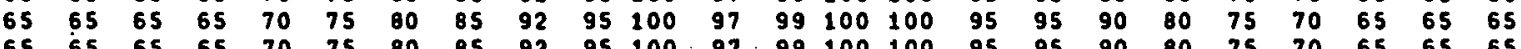

$100100100100100100100100100100100100100 \cdot 100100100100100100100100100100100$

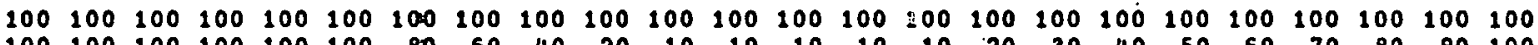
$\begin{array}{llllllllllllllllllllllllll}100 & 100 & 100 & 100 & 100 & 100 & 80 & 60 & 40 & 20 & 10 & 10 & 10 & 10 & 10 & 20 & 30 & 40 & 50 & 60 & 70 & 80 & 90 & 100\end{array}$ 
KEY TO TECHNOLOGIES IN TABLES OF RESULTS

END USE

Residential

Space Heat

Water Heat

Als Conditioning

Cooking

other

\section{Commerc1al}

Space Heat

Alr Conditionting

Other

Industrial

Transportation

(Automobile)

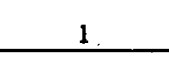

No Appllance

No Appllance

No Appllance

No Appl1ar.ce

No Appliance

No Appllance

No Appliance

No Appllance

No. Appllance
TECHNOLOGY

$$
2
$$

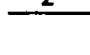

Gasto11 Furaace

Gas

Gas.

Gas:

Electric

\section{Gae $/ 011$} Furnace

Electric Resistance

Gas

Electric

Electric

Heat Pump

Electric

Heat Pump

Electric

Unnanaged Electric

Managed Electric Interruptib]
Service

Gasoline Electric
Central"

w/Storage

Solar

Control-

lable

Electrfe

\section{Electric} Heat Pump

Central

$-$

$-$

$-$

$-$
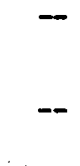

$-$

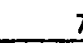

Dual-fueled Heat Pump

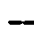

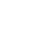

$-$
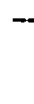
Appendix E

END-USE LOAD SHAPES 


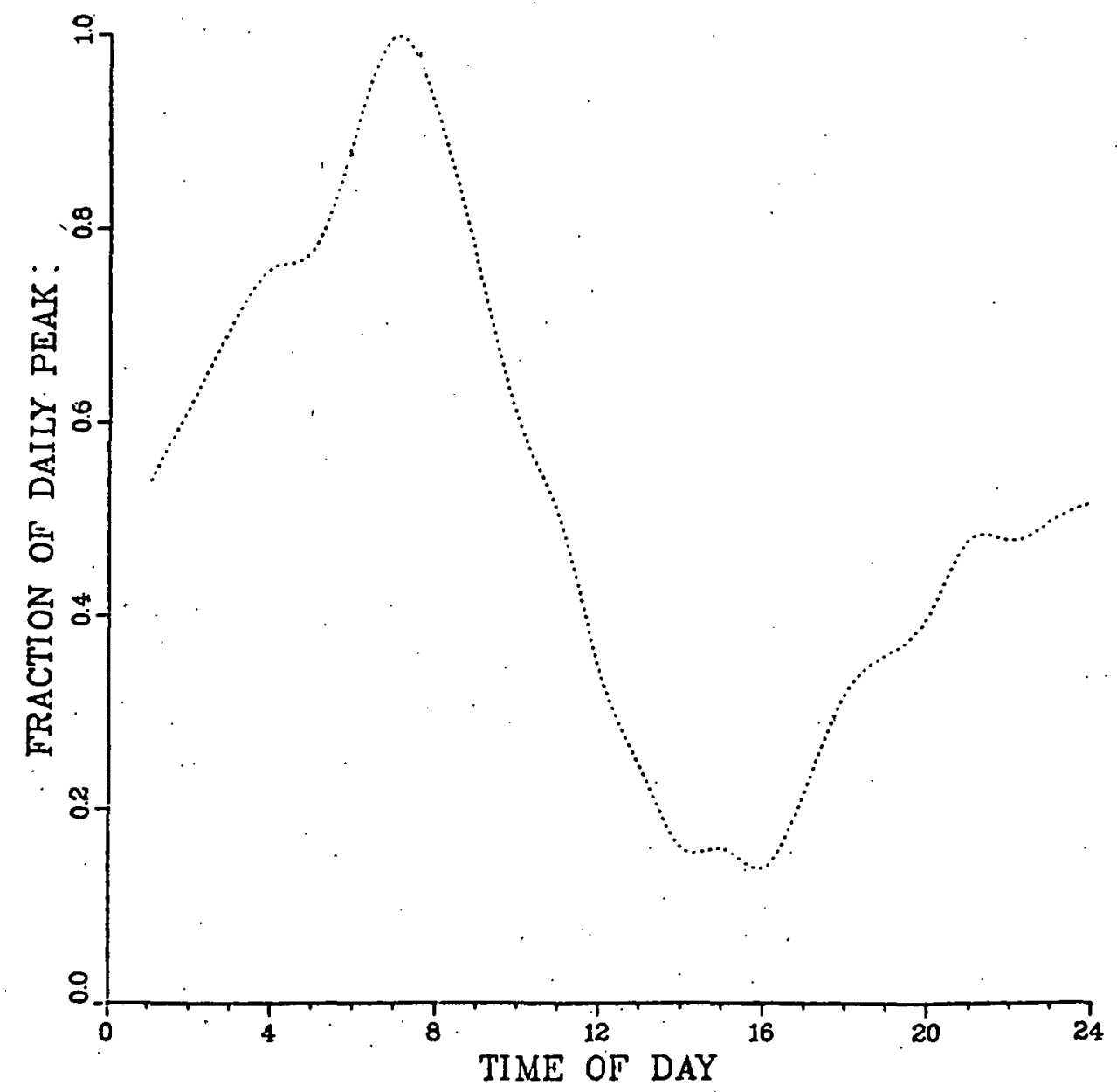

Figure E-1. Load Profile, Residential Space Heat Source: Load Research Committee of AEIC (Alabama, 1972)

$$
\mathrm{E}-1
$$




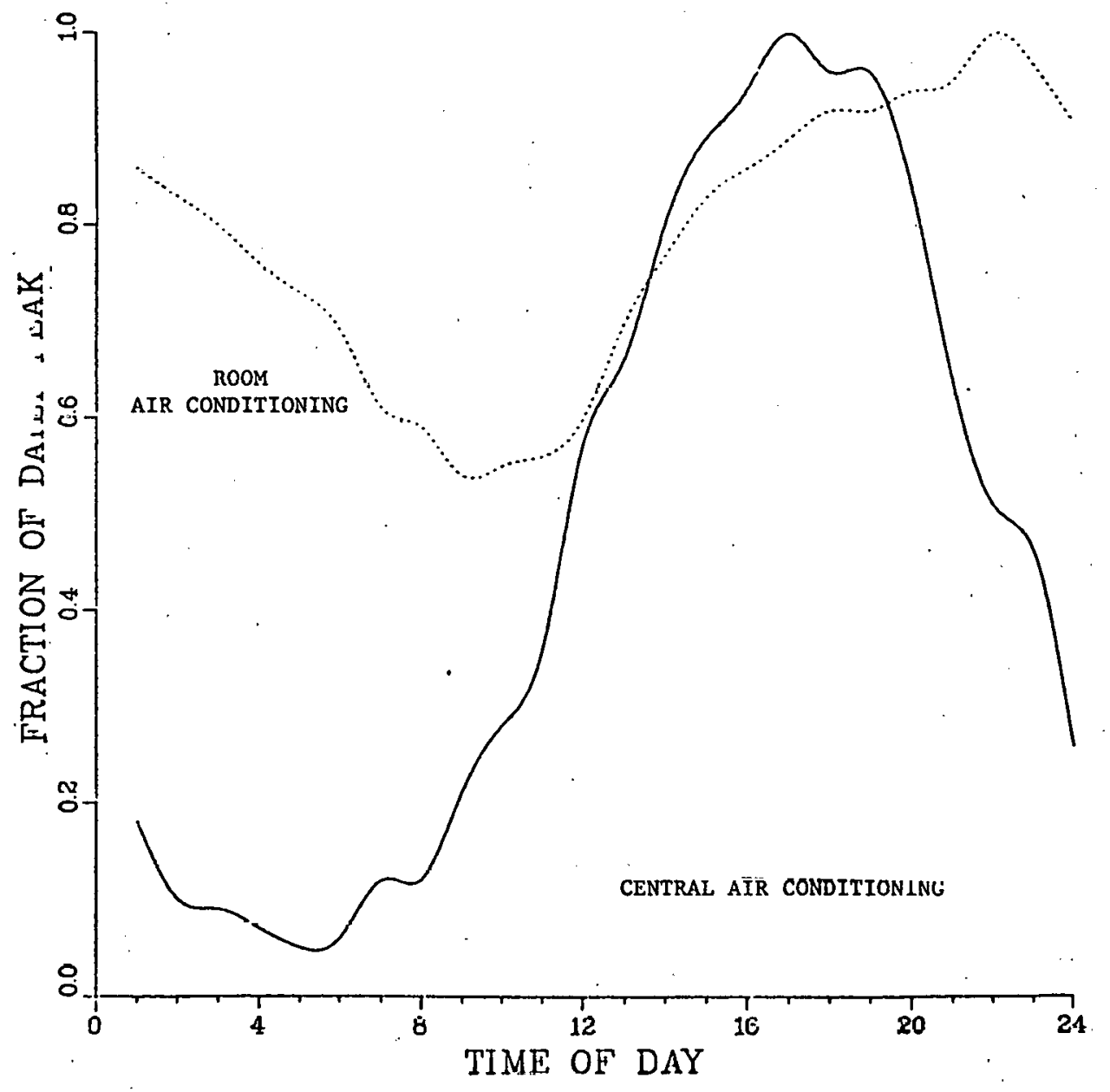

Figure E-2. Load Profiles, Residentlal Air Conditioning

Source: Room air conditioning - Elements of Load, Potomac Electric, Item 1.25 (1959); Central air conditioning Elements of Load, Potomac Electric, Item 1.27 (1959). 


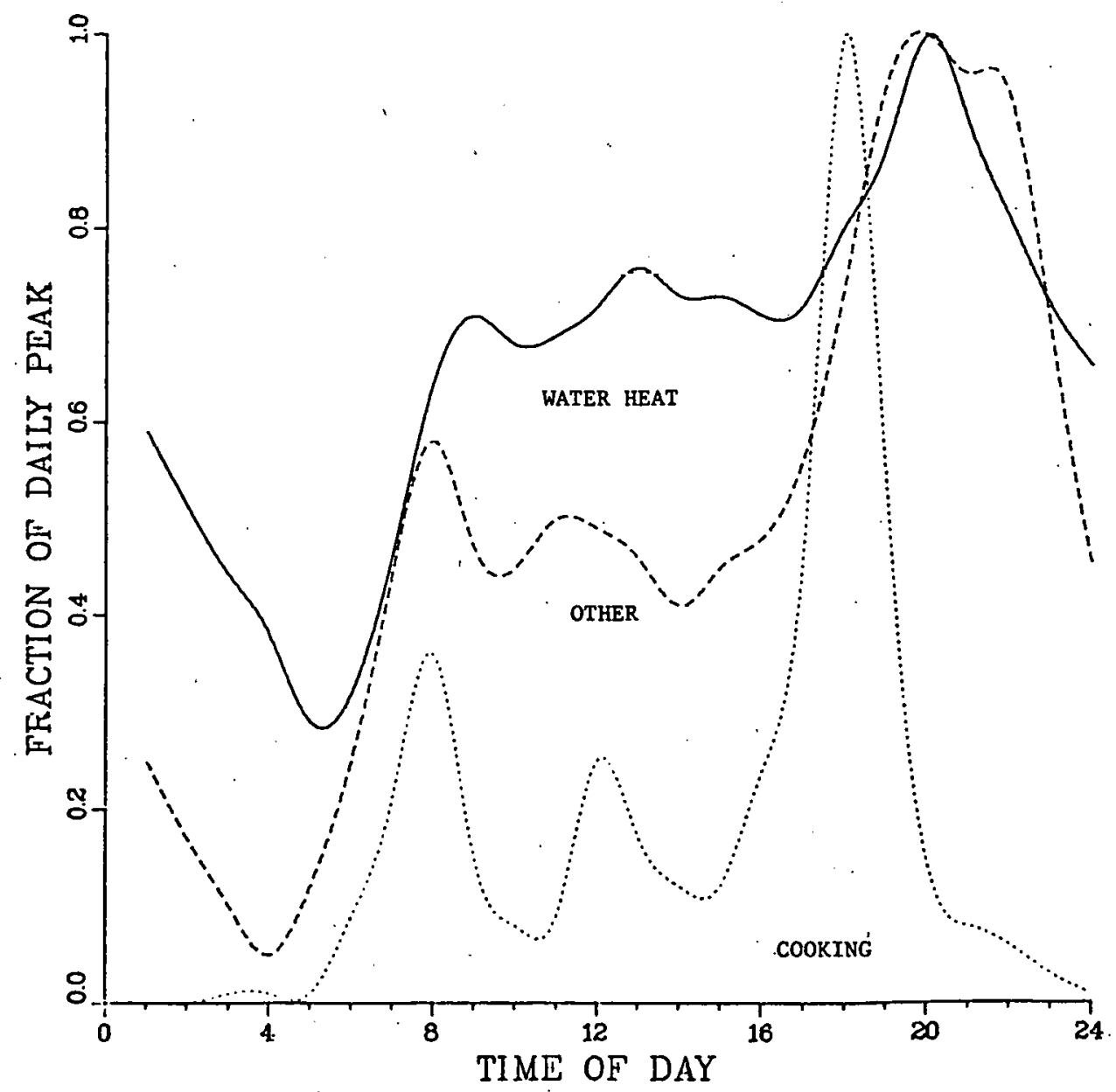

Figure E-3. Other Load Profiles, Residential Sector

Source: Water heat - Elements of Load, Potomac. Electric, Item 1.22 (1959); Cooking - Elements of Load, Item 1.21; Other - Elements of Load, Item 1.11. 


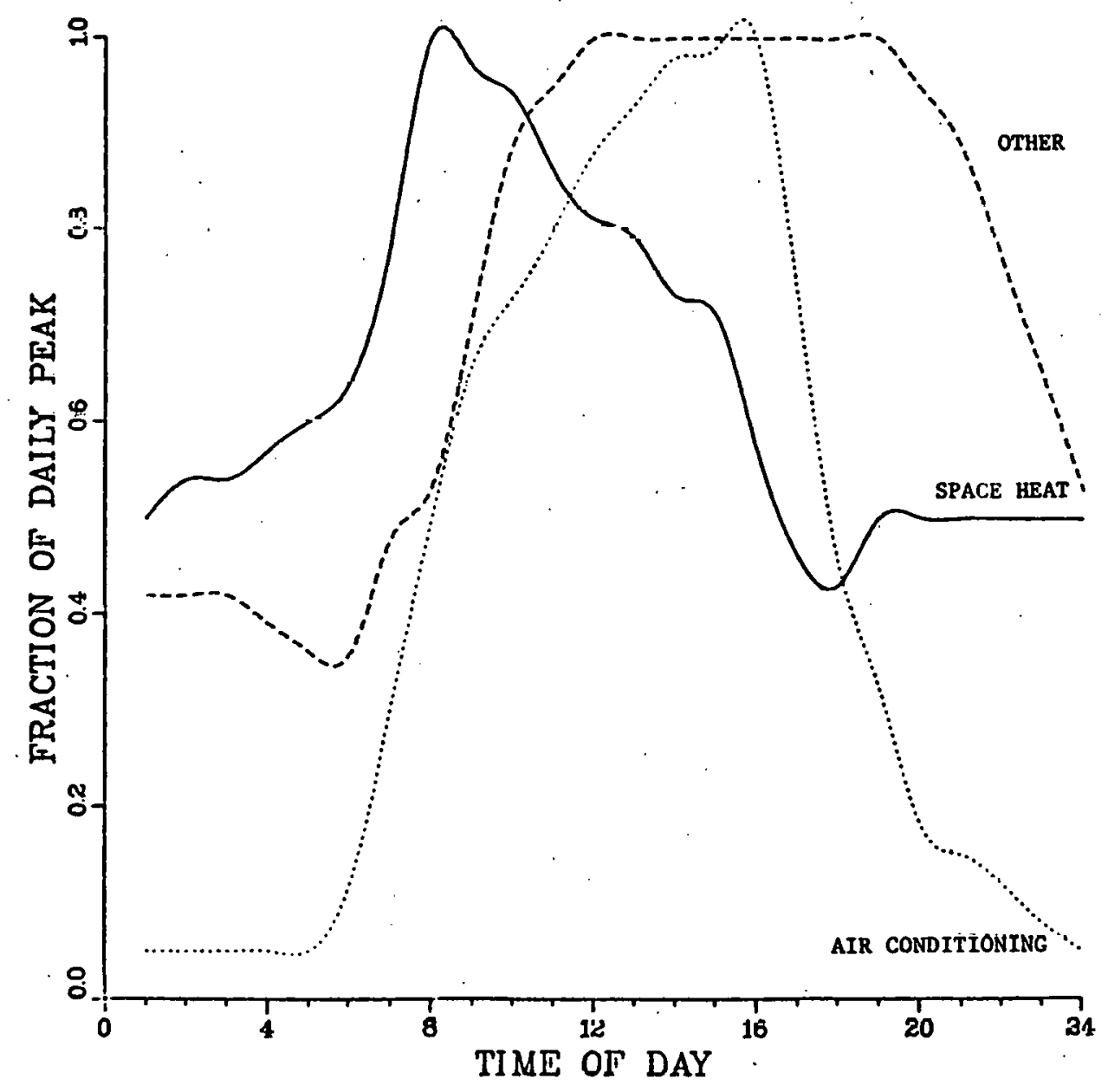

Figure E-4. Load Profiles, Commercial Sector

Source: Space heat - Load Research Committee of AEIC (Pennsylvania, 1971); Air conditioning - Elements of Load, Potomac Electric (1959); Other - Based on commercial load profiles during months when there is little heating or cooling demand. 


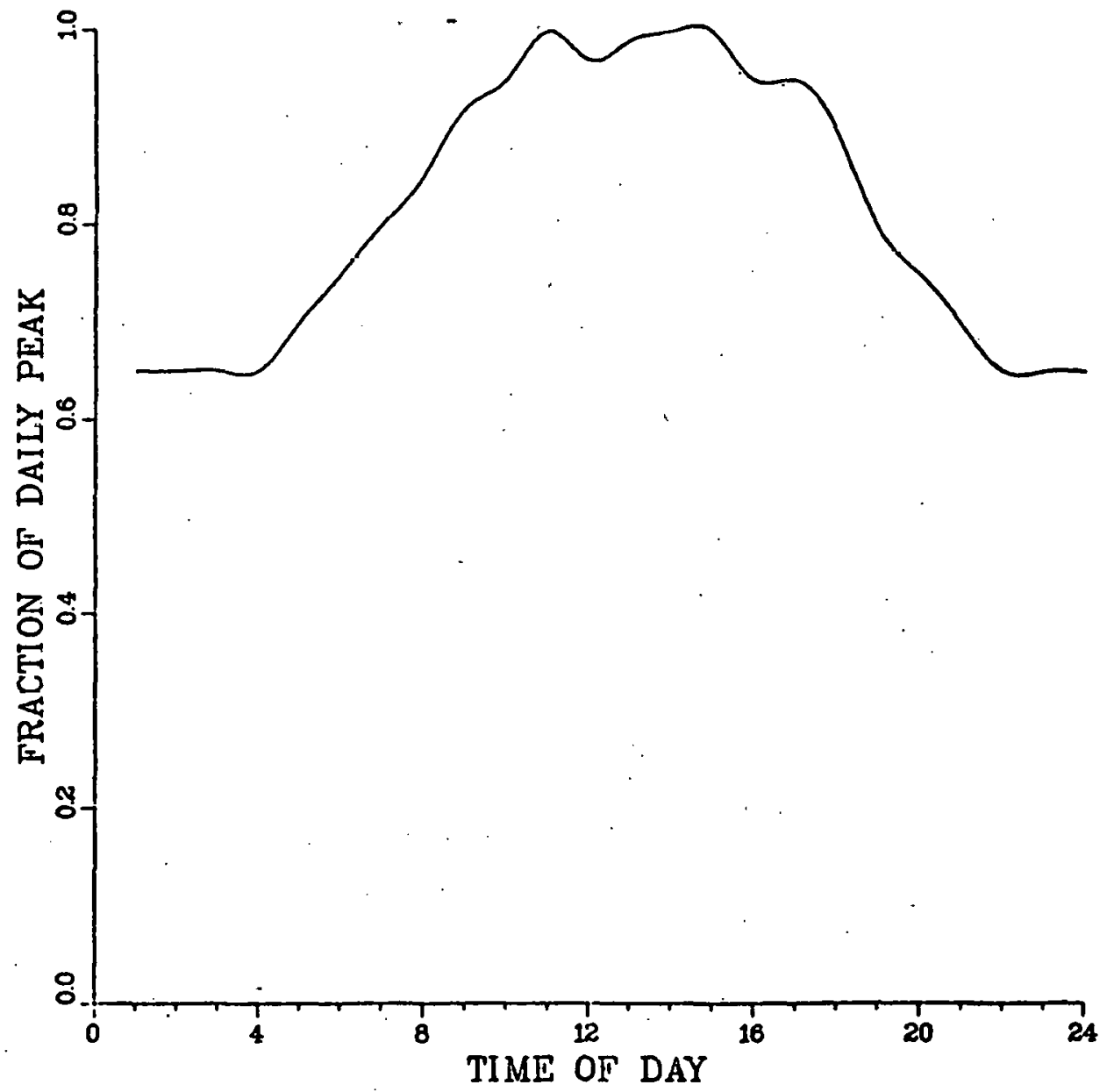

Figure E-5. Representative Load Profile for Industrial Sector

E-5 


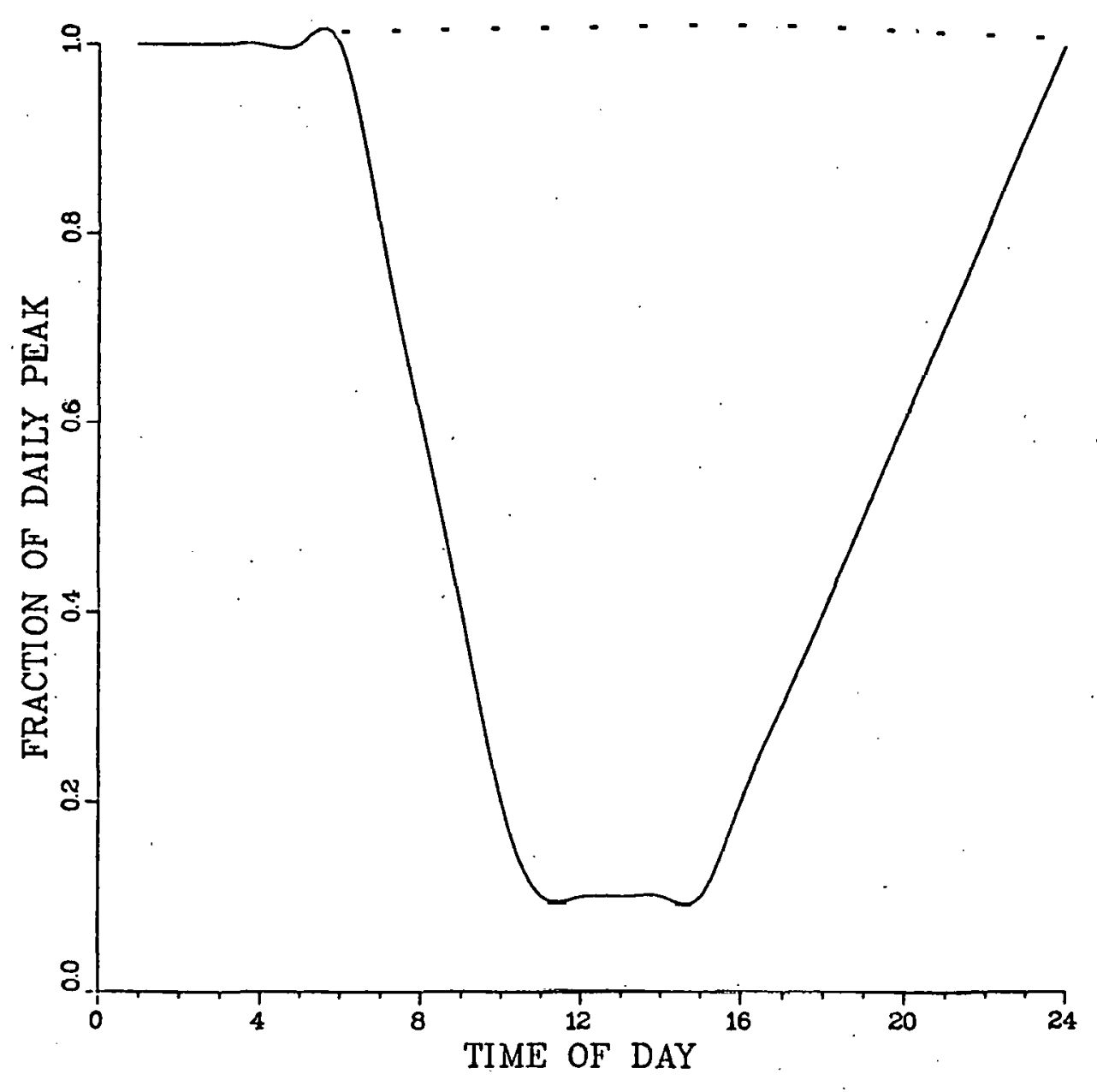

Figure E-6. Hypothetical Electric Car Load Shape 
Appendix F

OUTPUTS OF SENSITIVITY ANALYSIS RUNS

This appendix contains detailed computer output for the base cases and sensitivity analysis runs. The base case for the year 1980 is given in Table F-1 and for the year 2000 in Table F-2. Sensitivity cases 1 through 24 are given in Tables F-3 through F-26. The sensitivity cases are preceded by a description of the case and some comments on the results.

Each output table has two sections. The top section gives the amount of electric energy consumed by technologies and end uses. The bottom section contains seasonal and annual load factors, seasonal peak ratios, growth rates, and load by capacity factor. A key to technologies by number is given in a table immediately preceding Table F-1. 
Table F-1

BASE CASE YEAR I 980

( $\left.10^{12} \mathrm{Btu} / \mathrm{yr}\right)$

a. North Central Region

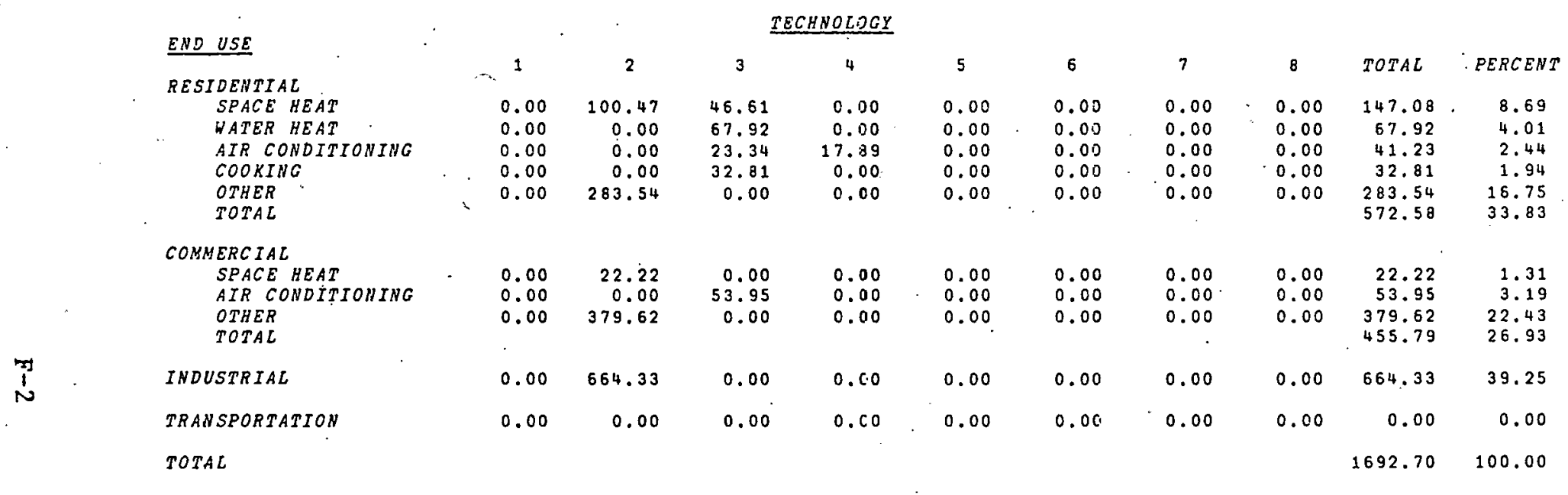

SUMMARY OUTPUTS -- NORTH CENTRAL $1980 \quad 12 / 18 / 79$

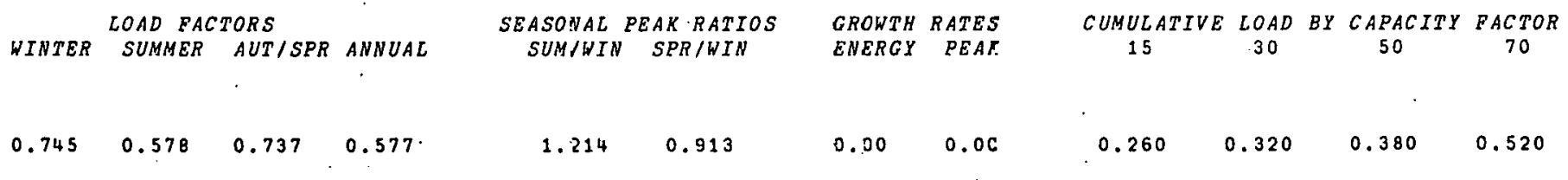


Table F-1, continued

b. South Central R.cgion

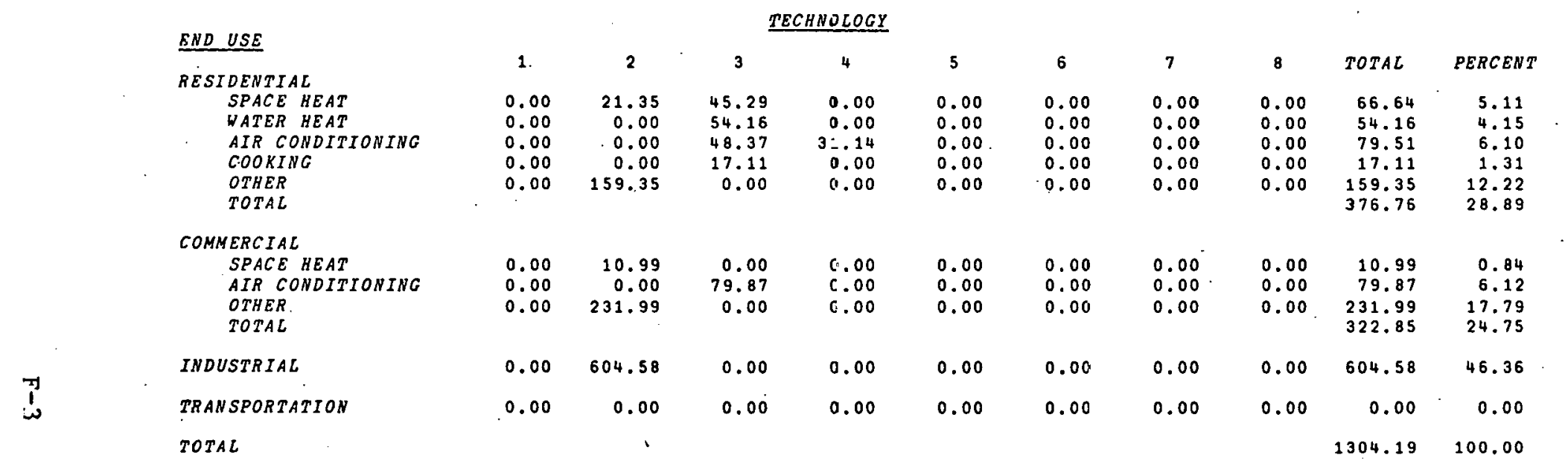

SUMMARY OUTPUTS -- SOUTH CENTRAL $1980 \quad 12 / 18 / 79$

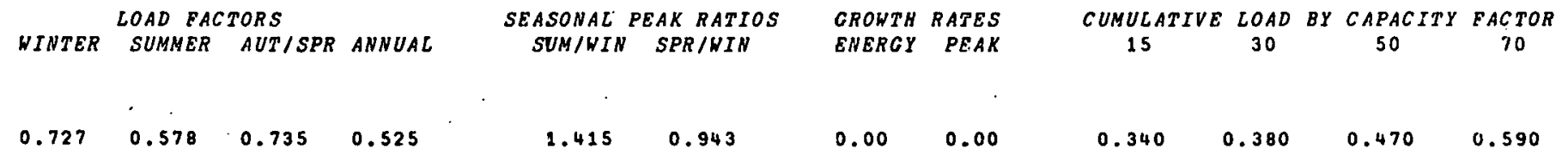


BASE CAJE YEAR 2000

$\left(10^{12} \mathrm{Btu} / \mathrm{yr}\right)$

a. Yozth Scniral Region

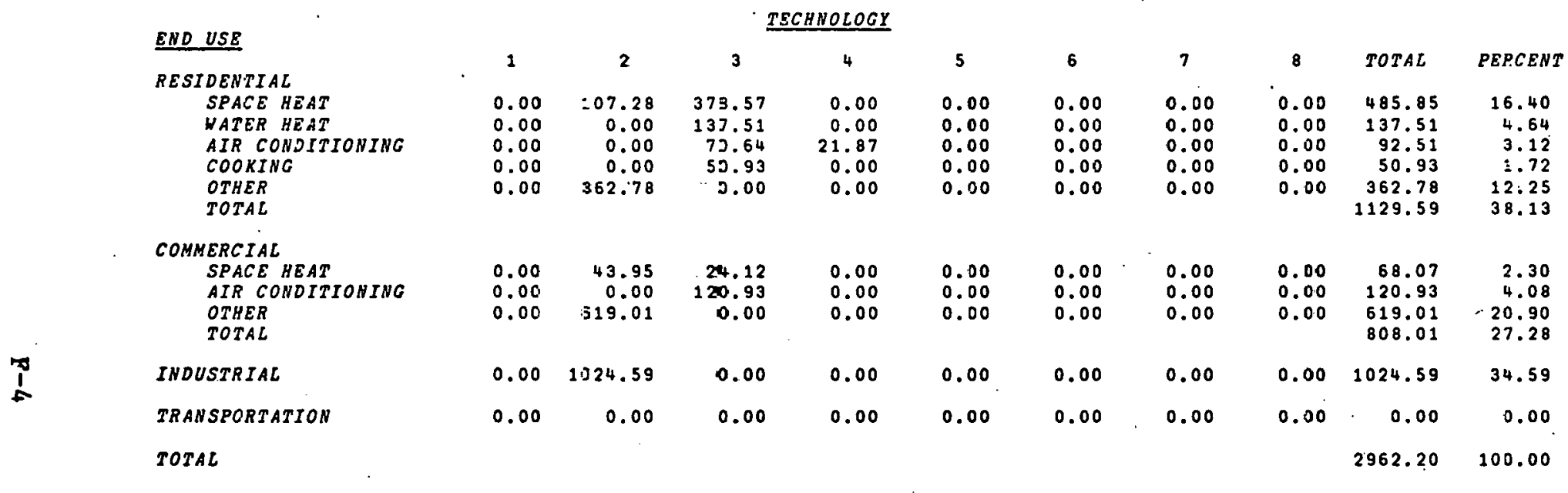

SUMMARY OUTFUTS - MORTH CBNTRAL 2000 12/28/79

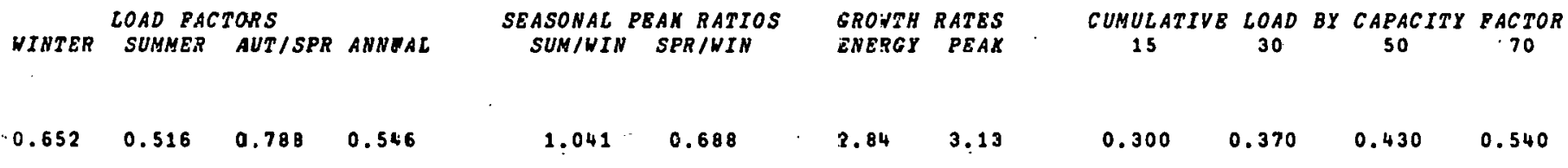


Table F-2, continued

b. South Central Region

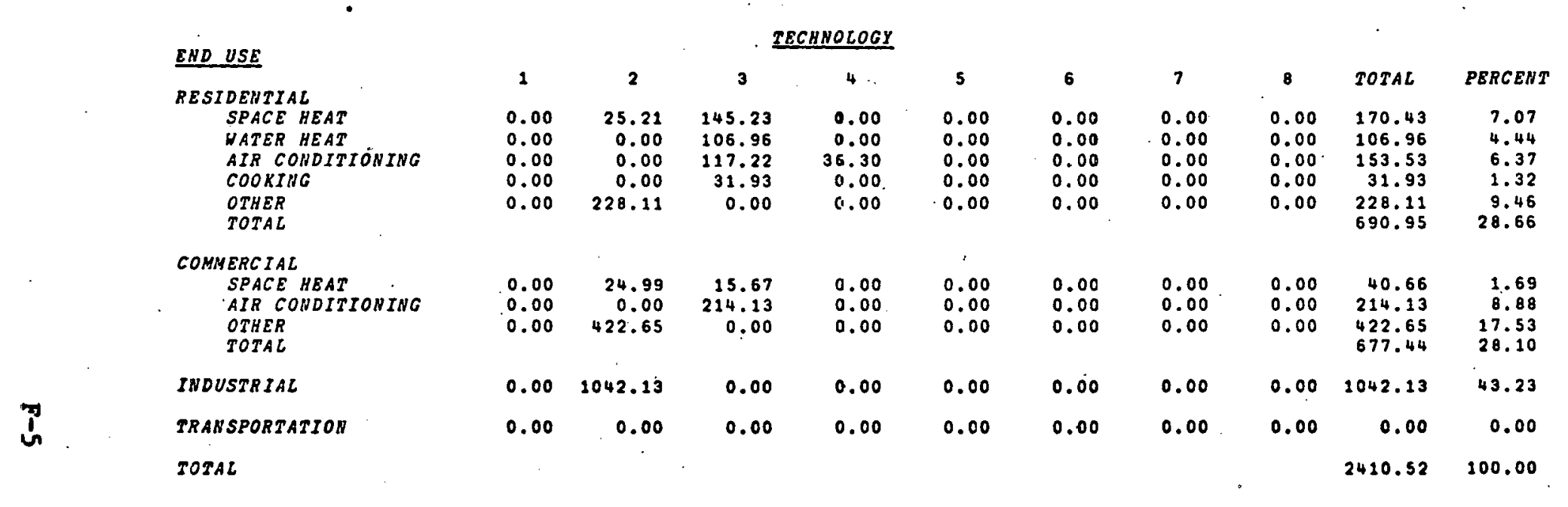

SUNAARY OUTPUTS -O SOUTH CENTRAL $2000 \quad 12 / 18 / 79$

\begin{tabular}{|c|c|c|c|c|c|c|c|c|c|c|c|}
\hline WINTER & $\begin{array}{c}\text { LOAD FAC } \\
\text { SUMNER }\end{array}$ & $\begin{array}{l}\text { TORS } \\
\text { AUT/SPR }\end{array}$ & ANNUAL & $\begin{array}{l}\text { SEASONAL } \\
\text { SUM/WIN }\end{array}$ & $\begin{array}{c}\text { EAR RATIOS } \\
\text { SPR /WIH }\end{array}$ & $\begin{array}{l}\text { GROWTH } \\
\text { ENBRGY }\end{array}$ & $\begin{array}{l}\text { RATES } \\
\text { PEAK }\end{array}$ & $\begin{array}{c}\text { CUMULATIVE } \\
15\end{array}$ & $\begin{array}{c}\angle O A D \\
30\end{array}$ & $\begin{array}{c}B Y \text { CAPACITY } \\
50\end{array}$ & $\begin{array}{c}\text { PACTOR } \\
70\end{array}$ \\
\hline 0.667 & 0.526 & 0.143 & 0.471 & 1.425 & 0.823 & 3.12 & 3. 68 & 0.400 & 0.450 & 0.520 & 0.630 \\
\hline
\end{tabular}


Case 1: High Industrial Growth Rate

Assumptions: Rate of growth of industrial energy demand is approximately twice the base case value ( $4.3 \%$ vs $2.2 \%$ in North Central, $5.5 \%$ vs $2.8 \%$ in South Central).

Results: The annual load factor increases by $4 \%$, largely due to the high load factor of the industrial sector. The system remains evenly balanced between summer and winter. The growth rate in demand for energy-increases by $25 \%$, the largest increase of any of the sensitivity cases. The rate of increase in peak demand is also large (18\%) but smaller than the change in energy growth. The industrial share of electric energy increases from $35 \%$ Lu $44 \%$ 
Table F-3

RESULTS OF SENSITIVITY CASE 1

HIGH GROWTH RATE, INDUSTRIAL

$$
\left(10^{12} \mathrm{Btu} / \mathrm{Yr}\right)
$$

a. North Central Region

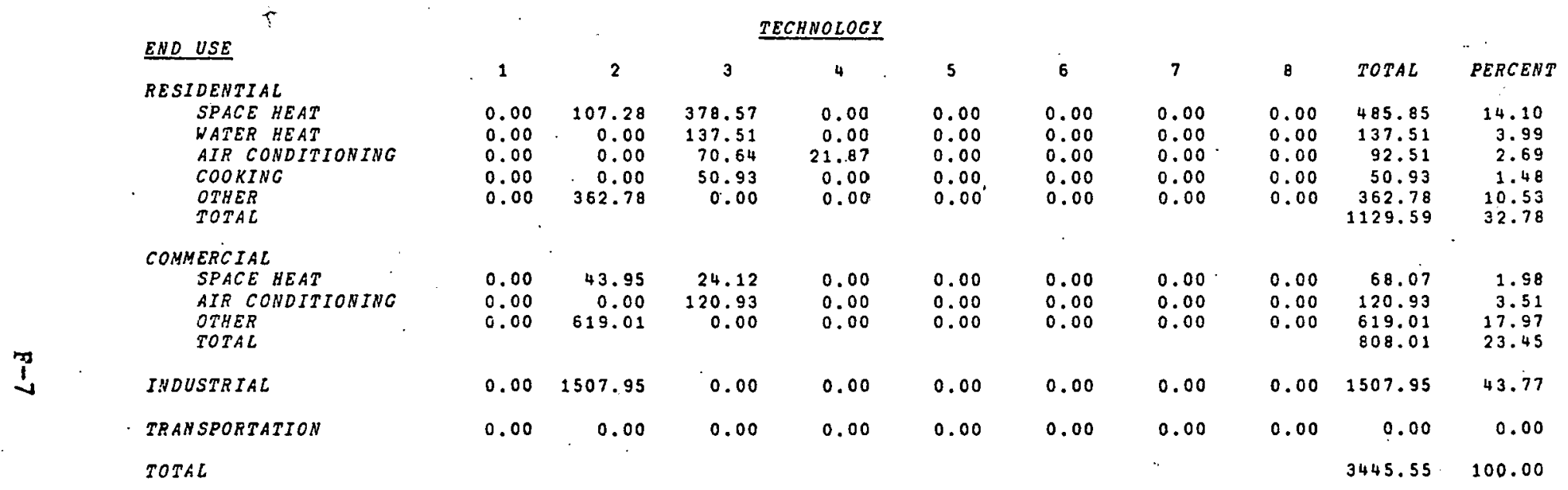

SUMMARY OUTPUTS -- NORTH CENTRAL $2000 \quad 12 / 18 / 79$ HIGH CROWTH RATE, INDUSTRIAL

\begin{tabular}{|c|c|c|c|c|c|c|c|c|c|c|c|c|c|}
\hline & WIHTER & $\begin{array}{l}\angle O A D \quad F A C \\
\text { SUMMER }\end{array}$ & $\begin{array}{l}\text { TORS } \\
\text { AUT / SPR }\end{array}$ & ANNUAL & $\begin{array}{l}\text { SEASONAL } \\
\text { SUM/WIN }\end{array}$ & $\begin{array}{l}\text { EAK RATIOS } \\
\text { SPR/WIN }\end{array}$ & $\begin{array}{l}\text { GROWTH } \\
\text { ENERGY }\end{array}$ & $\begin{array}{r}\text { RATES } \\
\text { PEAK }\end{array}$ & $\begin{array}{c}\text { CUMULATIVE } \\
15\end{array}$ & $\begin{array}{c}\angle O A D \\
30\end{array}$ & $B Y$ & $\begin{array}{l}\text { CAPACITY } \\
50\end{array}$ & $\begin{array}{c}\text { EACTOR } \\
70\end{array}$ \\
\hline$B A S E$ CASE & 0.652 & 0.516 & 0.788 & 0.546 & 1.041 & 0.688 & 2.84 & 3.13 & 0.300 & 0.370 & & 0.430 & 0.540 \\
\hline SCENARIO & 0.671 & 0.542 & 0.789 & 0.569 & 1.045 & 0.725 & 3.62 & 3.69 & 0.290 & 0.340 & & 0.410 & 0.520 \\
\hline DIFFERENCE & 0.019 & 0.025 & 0.001 & 0.023 & 0.005 & 0.037 & 0.78 & 0.56 & -0.010 & -0.030 & & -0.020 & -0.020 \\
\hline PERCEUTAGE & 2.9 & 4.9 & 0.1 & 4.2. & 0.5 & 5.4 & 27.5 & 18.1 & -3.3 & -8.1 & & -4.7 & -3.7 \\
\hline
\end{tabular}


Table F-3, Continued

b. South Central Region

\begin{tabular}{|c|c|c|c|c|c|c|c|c|c|c|c|}
\hline & END USE & & & & HNOLOGY & & & & & & \\
\hline & Dectorumer & 1 & 2 & 3 & 4 & s & 6 & 7 & 8 & TOTAL & PERCENT \\
\hline & $\begin{array}{l}\text { RESIDERTLAL } \\
\text { SPACE YEAT } \\
\text { WATER HEAT } \\
\text { AIR CONDITIOHING } \\
\text { COOKING }\end{array}$ & $\begin{array}{l}0.00 \\
0.00 \\
0.00 \\
0.00\end{array}$ & $\begin{array}{r}25.21 \\
0.00 \\
0.00 \\
0.00\end{array}$ & $\begin{array}{l}145.23 \\
106.96 \\
117.22 \\
31.93\end{array}$ & $\begin{array}{r}0.00 \\
0.00 \\
36.30 \\
0.00\end{array}$ & $\begin{array}{l}0.00 \\
0.00 \\
0.00 \\
0.00\end{array}$ & $\begin{array}{l}0.00 \\
0.00 \\
0.00 \\
0.00\end{array}$ & $\begin{array}{l}0.00 \\
0.00 \\
0.00 \\
0.00\end{array}$ & $\begin{array}{l}0.00 \\
0.00 \\
0.00 \\
0.00\end{array}$ & $\begin{array}{r}170.43 \\
106.96 \\
153.53 \\
31.93\end{array}$ & $\begin{array}{l}5.54 \\
3.48 \\
4.99 \\
1.04\end{array}$ \\
\hline & $\begin{array}{l}\text { OTHER } \\
\text { TOTAL }\end{array}$ & 0.00 & 228.11 & 0.00 & 0.00 & 0.00 & 0.00 & 0.00 & 0.00 & $\begin{array}{l}228.11 \\
690.95\end{array}$ & $\begin{array}{r}7.42 \\
22.48\end{array}$ \\
\hline & $\begin{array}{l}\text { COMHERCIAL } \\
\text { SPACE HEAT } \\
\text { AIR CONDITIONING } \\
\text { OTHER } \\
\text { TOTAL }\end{array}$ & $\begin{array}{l}0.00 \\
0.00 \\
0.00\end{array}$ & $\begin{array}{r}24.95 \\
0.00 \\
422.65\end{array}$ & $\begin{array}{r}15.67 \\
214.13 \\
0.00\end{array}$ & $\begin{array}{l}0.00 \\
0.00 \\
0.00\end{array}$ & $\begin{array}{l}0.00 \\
0.00 \\
0.00\end{array}$ & $\begin{array}{l}0.00 \\
0.00 \\
0.00\end{array}$ & $\begin{array}{l}0.00 \\
0.00 \\
0.00\end{array}$ & $\begin{array}{l}0.00 \\
0.00 \\
0.00\end{array}$ & $\begin{array}{r}40.66 \\
214.13 \\
422.65 \\
677.44\end{array}$ & $\begin{array}{r}1.32 \\
6.97 \\
13.75 \\
22.04\end{array}$ \\
\hline & INDUSTRIAL & 0.00 & 1705.49 & 0.00 & 0.00 & 0.00 & 0.00 & 0.00 & 0.00 & 1705.49 & 55.48 \\
\hline & TRANSPORTATION & 0.00 & 0.00 & 0.00 & 0.00 & 0.00 & 0.0 .0 & 0.00 & 0.00 & 0.00 & 0.00 \\
\hline & TOTAL & & & & & & & & & 3073.88 & 100.00 \\
\hline
\end{tabular}

SUMMARY OUYPUTS - SOUTH CENTRAL 2000 12/18/79 HIEH GROWTH RATE.INDUSTRIAL

\begin{tabular}{|c|c|c|c|c|c|c|c|c|c|c|c|c|}
\hline & WINTER & $\begin{array}{l}\text { LOAD } F A \\
\text { SUWNER }\end{array}$ & $\begin{array}{l}\text { RORS } \\
\text { AUT / SPR }\end{array}$ & ANNUAL & $\begin{array}{l}\text { SBASONAL } \\
\text { SUM/WIN }\end{array}$ & $\begin{array}{c}\text { PEAK RATIOS } \\
\text { SPR/WIN }\end{array}$ & $\begin{array}{l}\text { GROWTH } \\
\text { EUERGY }\end{array}$ & $\begin{array}{r}R A T E S \\
P E A K\end{array}$ & $\begin{array}{c}\text { CUMULATIV } \\
15\end{array}$ & $\begin{array}{c}V E C O A D \\
30\end{array}$ & $\begin{array}{c}B Y C A P A C I T Y \\
50\end{array}$ & $\begin{array}{c}\text { EACTOR } \\
70\end{array}$ \\
\hline BASE CASE & 0.657 & 0.526 & 0.743 & 0.471 & 1.425 & 0.823 & 3.12 & 3.68 & 0.400 & 0.450 & 0.520 & 0.630 \\
\hline SCENARTO & 0.700 & 0.558 & 0.748 & 0.513 & 1.370 & 0.876 & 4.38 & 4.50 & 0.360 & 0.390 & 0.490 & 0.590 \\
\hline DIFEERENCE & 0.033 & 0.032 & 0.005 & 0.042 & -0.054 & 0.053 & 1.26 & 0.83 & -0.040 & -0.060 & -0.030 & -0.040 \\
\hline 18 & 4.5 & 6.1 & 0.6 & 8.9 & -3.8 & 6.4 & 40.4 & 22.5 & -10.0 & -13.3 & -5.8 & -6.3 \\
\hline
\end{tabular}


Case 2: High Commercial Growth Rate

Assumptions: Rate of growth of the commercial sector is 1.5 times the base: case $(3.7 \%$ vs $2.5 \%$ in North Central, $4.7 \%$ vs $3.1 \%$ in South Central).

Results: The annual load factor decreases by about $7 \%$ and the system has a more dominant summer peak as in the 1980 case. The growth rate in peak demand increases by $25 \%$, one of the largest increases of any case. These results are due to the low load factor of the commercial sector and the coincidence of the air conditioning load with other commercial loads. 
Table F-4

RESULTS OF SENSITIVITY CASE 2

HIGH GROWTH RATES, COMMERCIA-

$\left(10^{12} \mathrm{Btu} / \mathrm{Yr}_{\mathrm{r}}\right)$

a. North Central Region

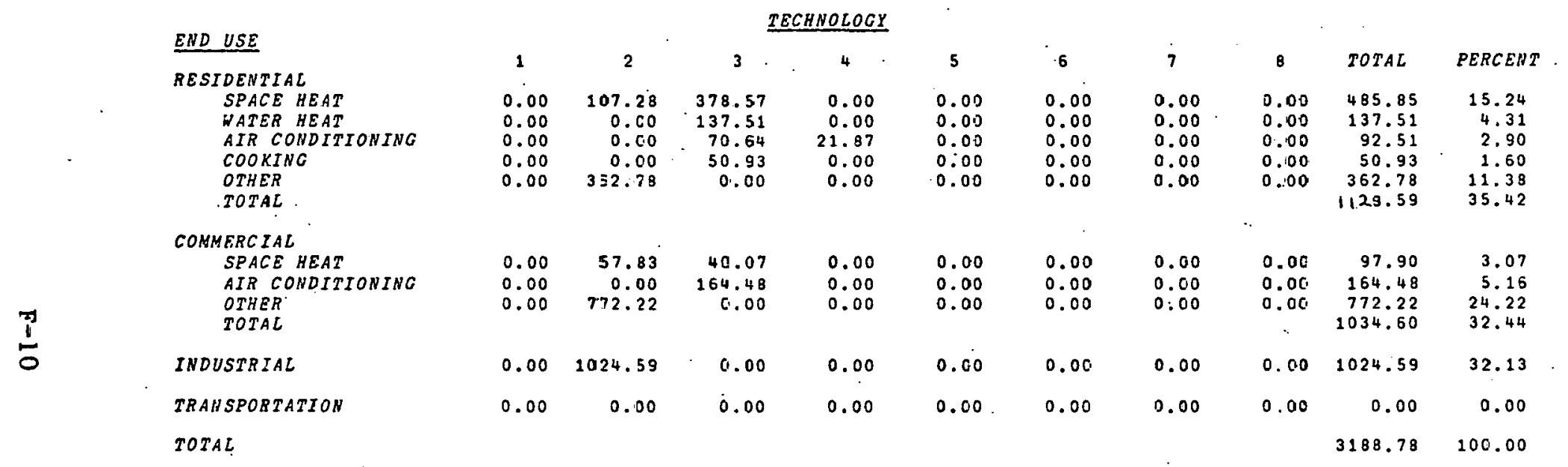

SUMMARY OUTPUTS -- NORTH CENTRAL $2000 \quad 12 / 18 / 79$ HICH GROHTH RATES, COMMERCIAL

\begin{tabular}{|c|c|c|c|c|c|c|c|c|c|c|c|c|c|}
\hline & WINTER & $\begin{array}{c}\angle O A D \quad E E O \\
\text { SUMNES }\end{array}$ & $\begin{array}{l}P O \overline{\bar{I}} S \\
A \because T / S P R\end{array}$ & ANNUAL: & $\begin{array}{l}\text { SEASONAL } \\
\text { SUM/WIN }\end{array}$ & $\begin{array}{c}\text { PEAK RATIOS } \\
\text { SPR/WIN }\end{array}$ & $\begin{array}{l}\text { CROPTH } \\
\text { ENEPGY }\end{array}$ & $\begin{array}{l}\text { RATES } \\
\text { PEAK }\end{array}$ & & $\begin{array}{c}\text { CUMULATIVE } \\
15\end{array}$ & $\begin{array}{c}E \angle O A D \\
30\end{array}$ & $\begin{array}{c}B Y C A P A C I T Y \\
50\end{array}$ & $\begin{array}{c}\text { FACTOR } \\
70\end{array}$ \\
\hline BASE CASE & 0.652 & 0.516 & 0.788 & 0.546 & 1.041 & 0.688 & 2.84 & 3.13 & & 0.300 & 0.370 & 0.430 & 0.540 \\
\hline SCENARIO & 0.650. & 0.493 & 0.785 & 0.509 & 1.144 & 0.700 & $3.2 ?$ & 3.87 & & 0.340 & 0.420 & 0.470 & 0.580 \\
\hline DIEEERENCE & 0.008 & -0.024 & -0.003 & -0.037 & 0.103 & 0.012 & 0.33 & 0.75 & & 0.040 & 0.050 & 0.040 & 0.040 \\
\hline PERCENTAGE & 1.2 & -4.6 & -0.4 & -6.7 & 9.9 & 1.8 & 13.4 & 23.9 & & 13.3 & 13.5 & 9.3 & 7.4 \\
\hline
\end{tabular}


Table F-4, Continued

\section{b. South Central Region}

\section{END USE}

RESIDENTIAL

SPACE
WEAT
WATER HEAT

WATER HEAT
AIR CONDITIONINC

OTHER

TOTAL

COMMERCIAL

SPACE HEAT

AIR CONDITIONING

OTHER

$\stackrel{1}{!}$

INLUSTR IAL

TRANSPORTATION

TOTAL

\begin{tabular}{|c|c|c|c|c|c|c|c|c|c|}
\hline & & & HNOLOG & & & & & & \\
\hline 1 & 2 & 3 & 4 & 5 & 6 & 7 & 8 & TOTAL & PERCENT \\
\hline 0.00 & 25.21 & 145.23 & 0.00 & 0.00 & 0.00 & 0.00 & 0.00 & 170.43 & 6.36 \\
\hline 0.00 & 0.00 & 106.96 & 0.00 & 0.00 & 0.00 & 0.00 & 0.00 & 106.96 & 3.99 \\
\hline 0.00 & 0.00 & 117.22 & 36.30 & 0.00 & 0.00 & 0.00 & 0.00 & 153.53 & 5.73 \\
\hline 0.00 & 0.00 & 31.93 & 0.00 & 0.00 & 0.00 & 0.00 & 0.00 & 31.93 & 1.19 \\
\hline 0.00 & 228.11 & 0.00 & 0.00 & 0.00 & 0.00 & 0.00 & 0.00 & $\begin{array}{l}228.11 \\
690.95\end{array}$ & $\begin{array}{r}8.51 \\
25.79\end{array}$ \\
\hline $\begin{array}{l}0.00 \\
0.00\end{array}$ & $\begin{array}{r}35.53 \\
0.00\end{array}$ & $\begin{array}{r}27.77 \\
316.60\end{array}$ & $\begin{array}{l}0.00 \\
0.00\end{array}$ & $\begin{array}{l}0.00 \\
0.00\end{array}$ & $\begin{array}{l}0.09 \\
0.00\end{array}$ & $\begin{array}{l}0.00 \\
0.00\end{array}$ & $\begin{array}{l}0.00 \\
0.00\end{array}$ & $\begin{array}{r}63.30 \\
316.60\end{array}$ & $\begin{array}{r}2.36 \\
11.82\end{array}$ \\
\hline 0.00 & 566.31 & 0.00 & 0.00 & 0.00 & 0.00 & 0.00 & 0.00 & $\begin{array}{l}566.31 \\
946.21\end{array}$ & $\begin{array}{l}21.14 \\
35.32\end{array}$ \\
\hline 0.00 & 1042.13 & 0.00 & 0.00 & $0: 00$ & 0.00 & 0.00 & 0.00 & 1042.13 & 38.90 \\
\hline 0.00 & 0.00 & 0.00 & 0.60 & 0.00 & 0.00 & 0.00 & 0.00 & 0.00 & 0.00 \\
\hline & & & & & & & & 2679.29 & 100.00 \\
\hline
\end{tabular}

SUMMARY OUTPUTS -- SOUTH CE.VTRAL $2000 \quad 12 / 18 / 79$

HICH GROWTH RATES, COMMERCIILL

LOAD RACTORS

WINTER SUMMER AUT/SPR ANWUAL

$\begin{array}{llll}0.667 & 0.526 & 0.743 & 0.471\end{array}$

$0.6720 .495 \quad 0.739,0.431$

SCENARIO

DIEFERENCE

PERCENTAGE

\section{SEASOVAL PEAK RATIOS}

SUM:WIN SPR/WIN

\begin{abstract}
1.225
\end{abstract}
1.6 .05

0.180

12.7
GROWTH RATES

ENERGY PEAK

3.123 .68

$3.67 \quad 4.68$

$0.55 \quad 1.01$

$17.5 \quad 27.4$
CUNULATIVE LOAD BY CAPACITY FACTOR

$15 \quad 30 \quad 50$

$50 \quad 70$

$\begin{array}{llll}0.400 & 0.450 & 0.520 & 0.630\end{array}$

$\begin{array}{llll}0.450 & 0.490 & 0.560 & 0.670\end{array}$

$0.050 \cdot 0.040 \quad 0.040 \quad 0.040$

$\begin{array}{llll}12.5 & 8.9 & 7.7 & 6.3\end{array}$ 
Case 3: Broader Peak on Residential and Commercial Alr Conditioning

Assumptions: The load shapes of commercial and residential central air conditioning are assumed to be about three hours wider around a peak at about $3 \mathrm{p} . \mathrm{m}$. This case is designed to test the sensitivity of system loads to the air conditioning load shape.

Results: The summer and annual load factors are both increased by about $4 \%$. The balance between summer and winter is maintained and the growth rate of peak demand decreases by $6 \%$. 
Table F-5

RESULTS OF SENSITIVITY CASE 3

BROADER PEAK ON AIR CONDITIONING

$$
\left(10^{12} \mathrm{Btu} / \mathrm{Yr}\right)
$$

a. North Central Region

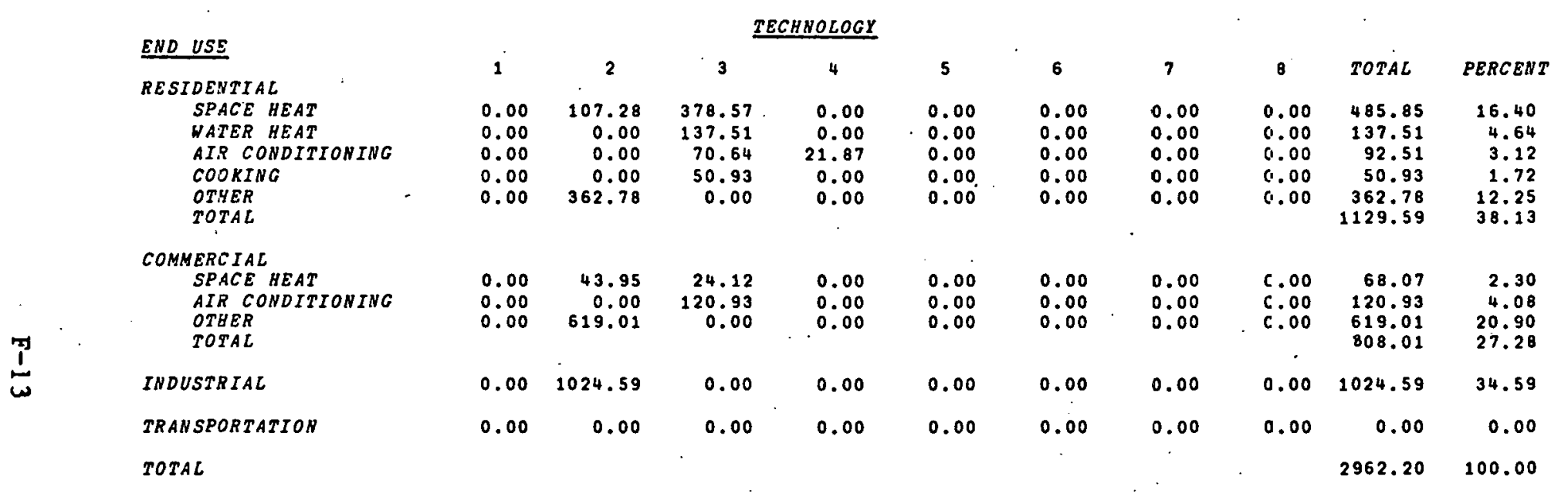

SUMMARY OUTPUTS -- NORTH CENTRAL 2000 12/18/79 BROADER PEAK ON AIR CONDITIONIHG

\begin{tabular}{lcccc} 
& & \multicolumn{5}{c}{ LOAD PACTORS } \\
& WINTER & SUMMER & AUT/SPR & ANNUAL. \\
BASE CASE & 0.652 & 0.516 & 0.788 & 0.546 \\
SCENARIO & 0.651 & 0.537 & 0.787 & 0.567 \\
DIFEERENCE & -0.000 & 0.021 & -0.001 & 0.021 \\
PERCENTAGE & -0.0 & 4.0 & -0.1 & 3.8
\end{tabular}

\begin{tabular}{|c|c|c|c|}
\hline $\begin{array}{l}\text { SEASONAL } \\
\text { SUM/WIS }\end{array}$ & $\begin{array}{c}E A K \text { RATIOS } \\
\text { SPR /WIN }\end{array}$ & $\begin{array}{l}\text { GROUTH } \\
\text { ENERGY }\end{array}$ & $\begin{array}{r}\text { RATES } \\
\text { PEAK }\end{array}$ \\
\hline 1.041 & 0.688 & 2.84 & 3.13 \\
\hline 1.002 & 0.688 & 2.84 & 2.93 \\
\hline-0.039 & 0.000 & 0.00 & -0.20 \\
\hline-3.8 & 0.0 & 0.0 & -6.3 \\
\hline
\end{tabular}

\begin{tabular}{|c|c|c|c|}
\hline $\begin{array}{l}\text { CUMULATIV } \\
15\end{array}$ & $\begin{array}{c}\text { E } \angle O A D \\
30\end{array}$ & $\begin{array}{c}B Y \text { CAPACITY } \\
50\end{array}$ & $\begin{array}{c}\text { PACTOR } \\
70\end{array}$ \\
\hline 0.300 & 0.370 & 0.430 & 0.540 \\
\hline 0.280 & 0.350 & 0.410 & 0.520 \\
\hline 0.020 & -0.020 & -0.020 & -0.020 \\
\hline 5.7 & -5.4 & -4.7 & -3.7 \\
\hline
\end{tabular}


Table F-5, Continued

b. South Central Region

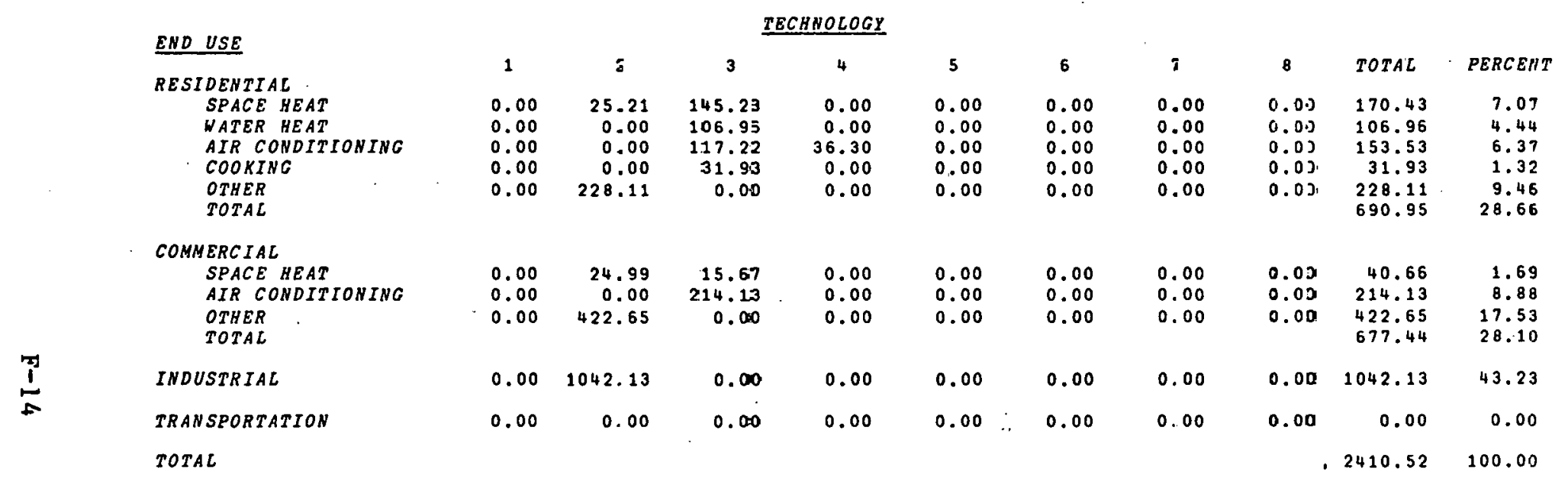

SUMMARY OUSPUTS -- SOUTH CENTRAL $2000 \quad 12 / 18 / 79$ BROADER PEAK CN AIR CONDITIONING

\begin{tabular}{|c|c|c|c|c|}
\hline & WINTER & $\begin{array}{l}\text { LOAD } E A C \\
\text { SUMMER }\end{array}$ & $\begin{array}{l}\text { TORS } \\
\text { AUT / SPR }\end{array}$ & ANKUAL \\
\hline BASE CASE & 0.667 & 0.526 & 0.743 & 0.471 \\
\hline SCENARIO & 0.667 & 0.557 & 0.733 & 0.199 \\
\hline DIPFERENCE & 0.000 & 0.030 & -0.013 & 0.028 \\
\hline PERCENTACE & 0.0 & 5.8 & $-1 . B$ & 6.0 \\
\hline
\end{tabular}

\begin{tabular}{cccc} 
SEASONAL & PEAK RATIOS & \multicolumn{3}{c}{ GROPTH } \\
SUMIWIN & SPRIWIN & ENERGY & PEAK \\
1.425 & 0.823 & 3.12 & 3.68 \\
1.345 & 0.839 & 3.12 & 3.38 \\
-0.080 & 0.016 & 0.00 & -0.30 \\
-5.6 & 1.9 & 0.0 & -8.1
\end{tabular}

CUMULATIVE LOAD BY CAPACITY FACTOR

$\begin{array}{lccc}15 & 30 & 50 & 50\end{array}$

$\begin{array}{llll}0.400 & 0.450 & 0.520 & 0.630\end{array}$

$0.370 \quad 0.410 \quad 0.490 \quad 0.610$

$\begin{array}{llll}-0.030 & -0.040 & -0.030 & -0.020\end{array}$

PERCENTACE

$0.0 .5 .8 \quad-1.8 \quad 6.0$ 
Case 4: High Peak-to-Normal Day Energy Ratio for Residential and Commercial Space Heat

Assumptions The peak-to-normal ratio for space heat is increased by $20 \%$ from 1.4 to 1.7 in both the residential and commercial sectors. (The change was 1.7 to 2.05 in South Centra1.) This ratio measures the relative amount of space heat energy demanded on a peak day relative to a normal day. A ratio of 1.4 implies that the demand for space heat energy, on a peak day is 1.4 times that of a normal winter day. The coldest $10 \%$ of all winter lays are called "peak."

Results: $\quad$ The winter load factor drops by over $9 \%$, causing a $6 \%$ decrease in annual load factor. The system becomes slightly winter peaking and the growth rate of peak load increases by about $10 \%$. This indicates that the results are quite sensitive to this ratio, especially if the system is seasonally balanced or is winter peaking. 
Table F-6

RESULTS OF SENSITIVITY CASE 4

HIGH PEAK-TO-NORMAL RATIO, SPACE HEAT

$$
\left(10^{12} \mathrm{Btu} / \mathrm{Yr}\right)
$$

a. North Central Region

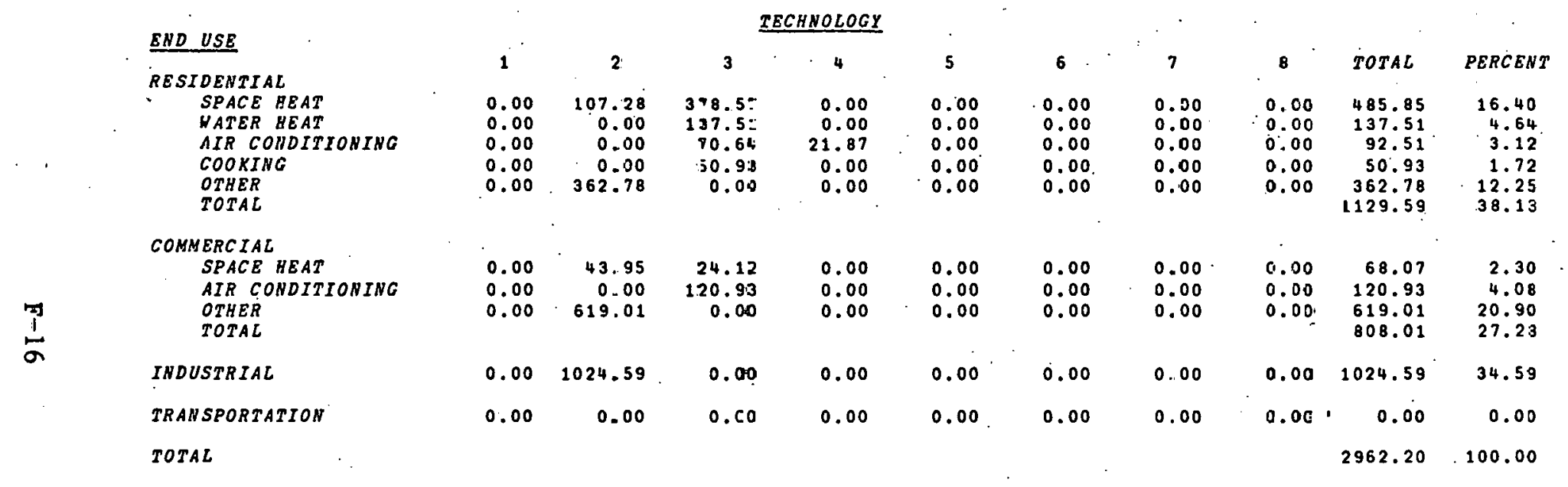

SUMMARY OUTPUTS -.. NORTH CENTRAL 2000

$12 / 18 / 79$ HIGH PEAK-TO-NORMAL RATIO.SPACE HEAT

\begin{tabular}{lcccc} 
& \multicolumn{5}{c}{$L$ LOAD EACTORS } \\
& WINTER & \multicolumn{4}{c}{ SUMNER AUT:SPR AMWUAL. } \\
BASE CASE & 0.652 & 0.516 & 0.738 & 0.546 \\
SCENARIO & 0.590 & 0.517 & 0.737 & 0.513 \\
DIRPERENCE & -0.062 & 0.000 & -0.031 & -0.033 \\
PERCENTACE & -9.4 & 0.0 & -0.1 & -6.0
\end{tabular}

\begin{tabular}{|c|c|c|c|}
\hline $\begin{array}{l}\text { SEASONAL } \\
\text { SUM/WIN }\end{array}$ & $\begin{array}{c}\text { PEAK RATIOS } \\
\text { SPR/VIN }\end{array}$ & $\begin{array}{l}\text { GROWTE } \\
\text { E.YERGS }\end{array}$ & $\begin{array}{r}\text { RATES } \\
\text { PEAK }\end{array}$ \\
\hline 1.041 & 0.688 & 2.84 & 3,13 \\
\hline 0.942 & 0.622 & 2.64 & 3.44 \\
\hline-0.099 & 0.065 & 0.010 & 0.31 \\
\hline-9.5 & -9.5 & 0.0 & 9.9 \\
\hline
\end{tabular}

$\begin{array}{cccc}\text { CUNULATIVE } & \text { LOAD } & \text { BY } & \text { CAPACITY } \\ .15 & 30 & 50 & \begin{array}{c}\text { FACTOR } \\ 70\end{array} \\ 0.300 & 0.370 & 0.430 & 0.540 \\ 0.340 & 0.410 & 0.460 & 0.570 \\ 0.040 & 0.040 & 0.030 & 0.030 \\ 13.3 & 10.8 & 7.0 & 5.6\end{array}$


Table F-6, Continued

b. South Central Region

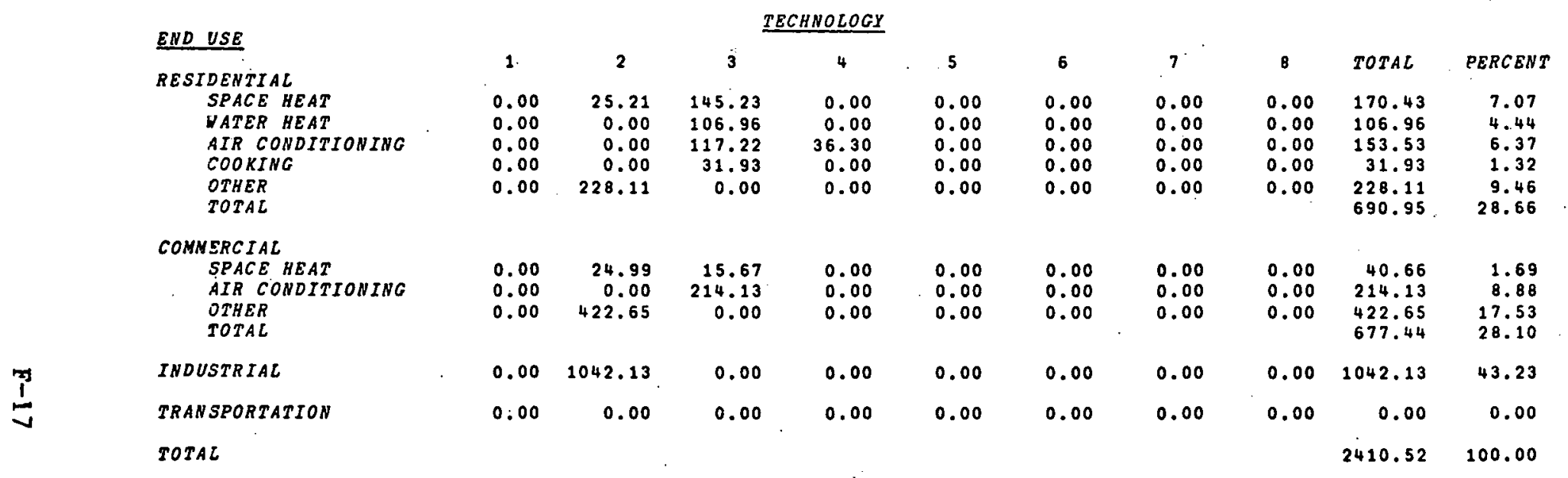

SUNMARY OUTPUTS -- SOUTH CENTRAL $2000 \quad 12 / 18 / 79$

HIGH PEAK-TO-NORMAL RATIO.SPACE HEAT

LOAD PACTORS

WINTER SUMMER AUT/SPR ANNUAL

$\begin{array}{lrrrr}\text { BASE CASE } & 0.667 & 0.526 & 0.743 & 0.471 \\ \text { SCENARIO } & 0.620 & 0.526 & 0.743 & 0.471 \\ \text { DIFFERENCE } & -0.047 & 0.000 & 0.000 & 0.000 \\ \text { PERCENTACE } & -7.0 & 0.0 & 0.0 & 0.0\end{array}$

SEASONAL PBAK RATIOS SUM/UIN SPR/WIU

$\begin{array}{cc}1.425 & 0.823 \\ 1.323 & 0.764 \\ -0.102 & -0.059 \\ -7.2 & -7.2\end{array}$

GROHTH RATBS

EUERGY PEAK

$3.12 \quad 3.68$

$3.123 .68^{\circ}$

$0.00 \quad 0.00$

$0.0 \quad 0.0$
CUNULATIVE LOAD BY CAPACITY EACTOR

$\begin{array}{cccc}15 & 30 & 50 & 70 \\ 0.400 & 0.450 & 0.520 & 0.630 \\ 0.390 & 0.450 & 0.520 & 0.630 \\ -0.010 & 0.000 & 0.000 & 0.000 \\ -2.5 & 0.0 & 0.0 & 0.0\end{array}$


Case 5: High Peak-to-Normal Day Ratio on Residential and Commercial Ai. Conditioning

Assumpttons: Peak-to-normal ratio in both the residential and commercial sectors is assumed to be $20 \%$ larger than the base case (2.4 vs 2.0 in North Central, 1.75 vs 1.46 in South Central.).

Results: The summer and annual load factors decrease by about $8 \%$ each, due to the larger comparative effect of peak summer days. Correspondingly, the growth rate in peak load increases substantially. 
Tab1e F-7

RESULTS OF SENSITIVITY CASE 5

HIGH PEAK-TO-NORMAL RATIO, AIR CONDITIONING

$$
\left(10^{12} \mathrm{Btu} / \mathrm{Yr}\right)
$$

\section{a. North Central Region}

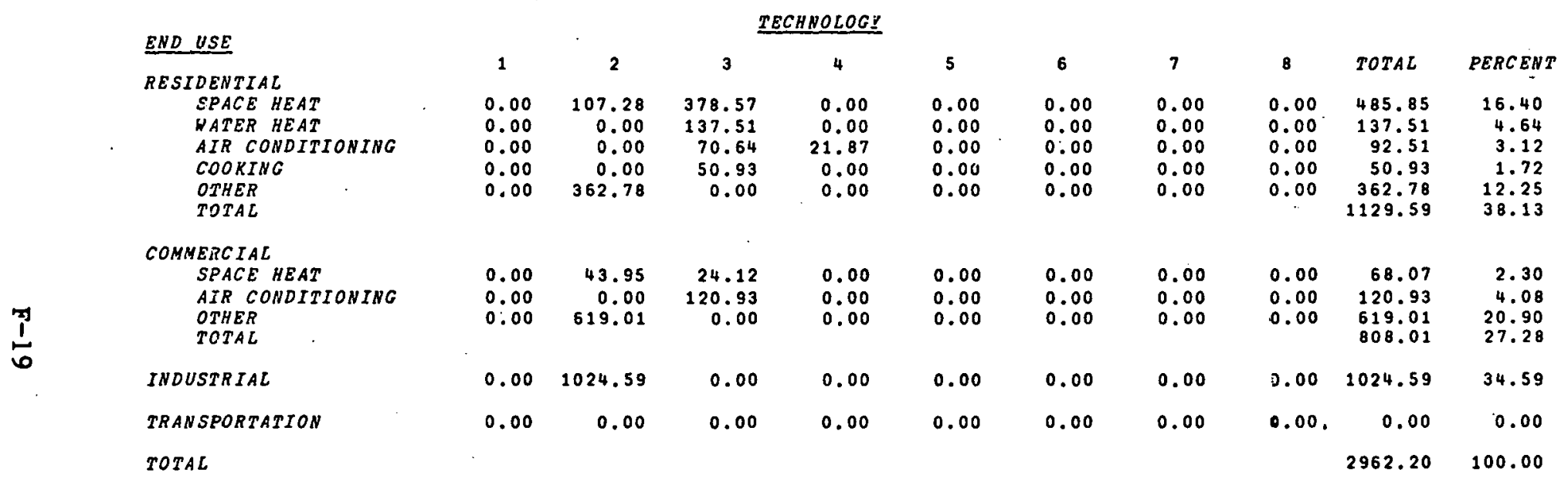

SUMMARY OUTPUTS -- NORTH CENTRAL $2000 \quad 12 / 18 / 79$

HIGH PEAK-TO-NORMAL RATIO.AIR CONDITIONING

\begin{tabular}{|c|c|c|c|c|c|c|c|c|c|c|c|c|c|}
\hline & WINTER & $\begin{array}{c}\angle O A D E A C \\
\text { SUMMER }\end{array}$ & $\begin{array}{l}\text { TORS } \\
\text { AUT / SPR }\end{array}$ & ANNUAL & $\begin{array}{l}\text { SEASONAL } \\
\text { SUM/WIN }\end{array}$ & $\begin{array}{c}\text { EAK RATIOS } \\
\text { SPR/WIN }\end{array}$ & $\begin{array}{l}\text { GROWTH } \\
\text { ENERGY }\end{array}$ & $\begin{array}{l}\text { RATES } \\
\text { PEAK }\end{array}$ & $\begin{array}{c}\text { CUNULATIVE } \\
15\end{array}$ & $\begin{array}{c}\angle O A D \\
30\end{array}$ & $B Y$ & $\begin{array}{l}\text { CAPACITY } \\
50\end{array}$ & $\begin{array}{c}\text { PACTOR } \\
70\end{array}$ \\
\hline$B A S E$ CASE & 0.652 & 0.516 & 0.788 & 0.546 & 1.041 & 0.688 & 2.84 & 3.13 & 0.300 & 0.370 & & 0.430 & 0.540 \\
\hline SCENARIO & 0.652 & 0.477 & 0.787 & 0.504 & 1.127 & 0.688 & 2.84 & 3.54 & 0.360 & 0.420 & & 0.470 & 0.580 \\
\hline DIFPERENCE & 0.000 & -0.039 & -0.001 & -0.042 & 0.086 & 0.000 & 0.00 & 0.41 & 0.060 & 0.050 & & 0.040 & 0.040 \\
\hline PERCENTACE & 0.1 & -7.6 & -0.1 & -7.7 & 8.3 & 0.0 & 0.0 & 13.2 & 20.0 & 23.5 & & 9.3 & 7.4 \\
\hline
\end{tabular}


Table F-7, Continued

b. South Central Region

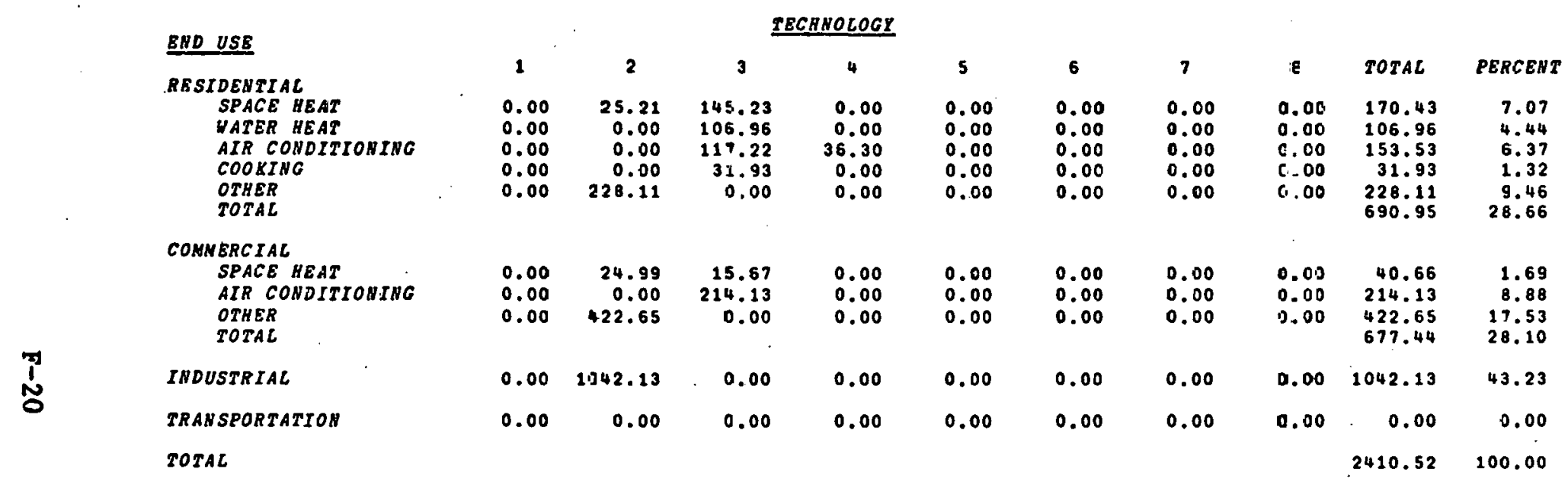

SUMNARI OUTPUTS -. SOUTR CENTRAL 2000 12/18/79

HIGR PEAK-TO-NORMAL RATIO,AIR CORDITIONIHG

\begin{tabular}{|c|c|c|c|c|c|c|c|c|c|c|c|c|}
\hline & WINTER & $\begin{array}{l}\text { LOAD FAC } \\
\text { SUNNER }\end{array}$ & $\begin{array}{l}\text { TORS } \\
\text { AUT / SPR }\end{array}$ & ANMUAL & $\begin{array}{l}\text { SEASONAL } \\
\text { SUN/WIN }\end{array}$ & $\begin{array}{c}\text { PEAK RATTOS } \\
\text { SPR/WIA }\end{array}$ & $\begin{array}{l}\text { GROWTH } \\
\text { ENERGY }\end{array}$ & $\begin{array}{l}\text { RATES } \\
\text { PEAK }\end{array}$ & $\underset{15}{\text { CUNULATIVE }}$ & $\begin{array}{c}C O A D \\
30\end{array}$ & $\begin{array}{c}B Y \text { CAPACITY } \\
50\end{array}$ & $\begin{array}{c}\text { PACTOR } \\
70\end{array}$ \\
\hline BASE CASE & 0.667 & 0.526 & 0.743 & 0.471 & 1.425 & 0.823 & 3.12 & 3.68 & 0.400 & 0.450 & 0.520 & 0.630 \\
\hline SCENARTO & 0.668 & 0.481 & 0.745 & 0.431 & 1.551 & 0.823 & 3.12 & 4.15 & 0.450 & 0.490 & 0.560 & 0.670 \\
\hline DIERERENCE & 0.000 & -0.046 & 0.001 & -0.040 & 0.136 & 0.000 & 0.00 & 0.47 & 0.050 & 0.040 & 0.040 & 0.040 \\
\hline PERCEUTAGE & 0.1 & -8.7 & 0.1 & -1.5 & 9.6 & 0.0 & 0.0 & 12.9 & 12.5 & 8.9 & . 7.7 & 6.3 \\
\hline
\end{tabular}


Case 6: High Original Market Size for Commercial Air Conditioning

Assumptions: Original market size of conmercial air conditioning is 1.5 times base case (460 vs $307 \times 10^{12} \mathrm{Btu} / \mathrm{yr}$ in North Central, 669 vs 464 in South Central).

Results: The annual load factor decreases by almost $12 \%$, which is the second largest decrease of all sensitivity cases. The growth rate of peak demand Increases by $24 \%$, also one of the largest increases of any case. Clearly the model is very censitive to this uncertain quantity. 
Table F-8

RESULTS OF SENSITIVITY CASE 6

HIGH ORIGINAL MARKET SIZE, COMMERCIAL AIR CONDITIONING

$\left(10^{12} \mathrm{Btu} / \mathrm{Yr}\right)$

a. North Central Region

\begin{tabular}{|c|c|c|c|c|c|c|c|c|c|c|c|}
\hline & END USE & & & & HNOLOG & & & & & & \\
\hline & $\begin{array}{l}\text { RNDUSE } \\
\text { RESIDENTIAL }\end{array}$ & 1 & 2 & 3 & 4 & 5 & 6 & 7 & 8 & TOTAL & PERCENT \\
\hline & SPACE HEAT & 0.00 & 107.28 & 378.57 & 0.00 & 0.00 & 0.00 & 0.00 & 0.00 & 485.85 & 16.07 \\
\hline & $\begin{array}{l}\text { WATER HE.AT } \\
\text { AIR CONDITIONING }\end{array}$ & $\begin{array}{l}0.00 \\
0.00\end{array}$ & $\begin{array}{l}0.00 \\
0.00\end{array}$ & $\begin{array}{r}137.51 \\
70.64\end{array}$ & $\begin{array}{r}0.00 \\
21.87\end{array}$ & $\begin{array}{l}0.00 \\
0.00\end{array}$ & 0.00 & 0.00 & 0.00 & $\begin{array}{r}137.51 \\
92.51\end{array}$ & $\begin{array}{l}4.55 \\
3.06\end{array}$ \\
\hline . & $\begin{array}{l}\text { COOKING } \\
\text { OTHER } \\
\text { TOTAL }\end{array}$ & $\begin{array}{l}0.00 \\
0.00\end{array}$ & $\begin{array}{r}0.00 \\
362.78\end{array}$ & $\begin{array}{r}50.93 \\
0.00\end{array}$ & $\begin{array}{l}0.00 \\
0.00\end{array}$ & $\begin{array}{l}0.00 \\
0.00\end{array}$ & $\begin{array}{l}0.00 \\
0.00\end{array}$ & $\begin{array}{l}0.00 \\
0.00\end{array}$ & $\begin{array}{l}0.00 \\
0.00\end{array}$ & $\begin{array}{r}50.93 \\
362.78 \\
1129.59\end{array}$ & $\begin{array}{r}1.69 \\
12.00 \\
37.37\end{array}$ \\
\hline . & $\begin{array}{l}\text { COMMERCIAL } \\
\text { SPACE }\end{array}$ & 0.00 & $=3.95$ & 24,12 & 0.00 & 0.00 & 0.00 & 0.00 & 0.00 & 68.07 & 2.25 \\
\hline & $\begin{array}{l}\text { AIR CONDITIONING } \\
\text { OTHER } \\
\text { TOTAL }\end{array}$ & $\begin{array}{l}0.00 \\
0.00\end{array}$ & $\begin{array}{r}0.00 \\
619.01\end{array}$ & $\begin{array}{r}181.19 \\
0.00\end{array}$ & $\begin{array}{l}0.00 \\
0.00\end{array}$ & $\begin{array}{l}0.00 \\
0.00\end{array}$ & $\begin{array}{l}0.00 \\
0.00\end{array}$ & $\begin{array}{l}0.00 \\
c .00\end{array}$ & $\begin{array}{l}0.00 \\
0.00\end{array}$ & $\begin{array}{r}181.19 \\
619.01 \\
68.28\end{array}$ & $\begin{array}{r}5.99 \\
20.48 \\
28.73\end{array}$ \\
\hline & INDUSTR IAL & 0.00 & 1024.59 & $c .00$ & 0.00 & 0.00 & 0.00 & 0.00 & 0.00 & 1024.59 & 33.90 \\
\hline & TRAN SPORTATION & 0.00 & 0.00 & $c .00$ & 0.00 & 0.00 & 0.00 & 0.00 & 0.00 & 0.00 & 0.00 \\
\hline & TOTAL & & & & & & . & & & 3022.46 & 100.00 \\
\hline
\end{tabular}

SUMMARY OUTPUTS - - NORTH CENTRAL $2000 \quad 12 / 18 / 7 \mathrm{~J}$

HIGH ORIGINAL MARKET SIZE.COMMERCIAL AIR CONDITIOHING

\begin{tabular}{|c|c|c|c|c|c|c|c|c|c|c|c|c|}
\hline & WIHTER & $\begin{array}{c}\text { COAD } B A C \\
\text { SUMMER }\end{array}$ & $\begin{array}{l}\text { TORS } \\
\text { ACT/SPR }\end{array}$ & $A N N U \square C$ & $\begin{array}{l}\text { SEASONAL } \\
\text { SUM/WIN }\end{array}$ & $\begin{array}{c}\text { PEAK RATIOS } \\
\text { SPR / WIN }\end{array}$ & $\begin{array}{l}\text { GROWTH } \\
\text { ENERGY }\end{array}$ & $\begin{array}{l}\text { RATES } \\
\text { PEAK }\end{array}$ & $\begin{array}{c}\text { CUNULATIVE } \\
15\end{array}$ & $\begin{array}{c}E \angle O A D \\
30\end{array}$ & $\begin{array}{c}B Y C A P A C I T Y \\
50\end{array}$ & $\begin{array}{c}\text { FACTOR } \\
70 .\end{array}$ \\
\hline BASE CASE & 0.652 & 0.516 & 0.788 & 0.545 & 1.041 & 0.688 & 2.84 & 3.13 & 0.300 & 0.370 & 0.430 & 0.540 \\
\hline SCENARIO & 0.652 & 0.475 & 0.788 & 0.481 & 1.205 & 0.688 & .2 .94 & 3.88 & 0.380 & 0.450 & 0.510 & 0.600 \\
\hline DIFFERENCE & 0.001 & -0.041 & -0.000 & -0.065 & 0.164 & 0.000 & 0.10 & 0.76 & 0.080 & 0.080 & 0.080 & 0.060 \\
\hline PERCENTAGE & 0.1 & -8.0 & -0.0 & -11.9 & 15.8 & 0.0 & 3.: & 24.3 & 26.7 & 21.5 & 18.6 & 11.1 \\
\hline
\end{tabular}


b. South Central Region

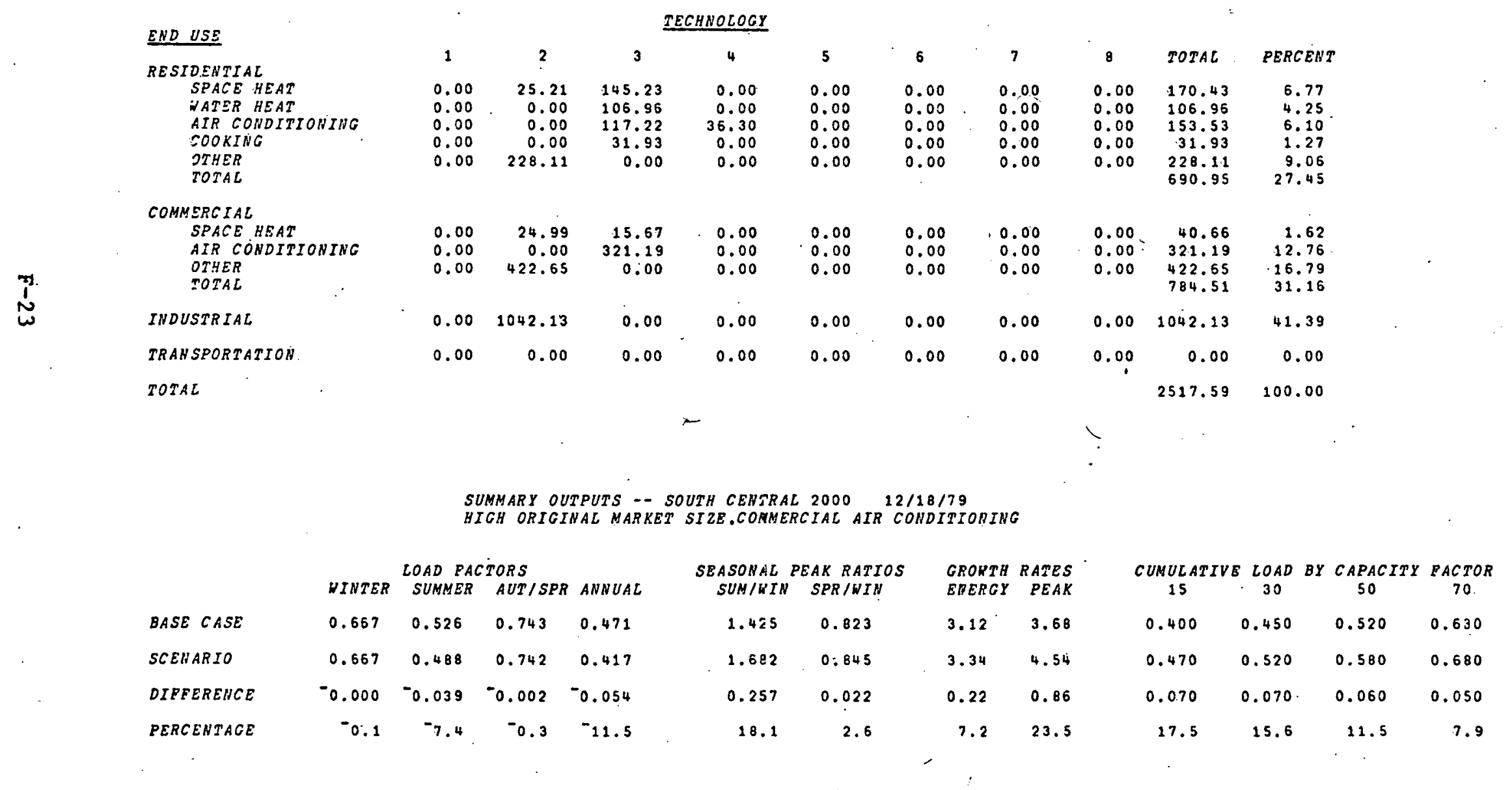


Case 7: $\quad$ Shift of Seasonal Allocation of Energy in Residential Water Heat

Assumptions: Base case assumption is that water heat use is the same per day regardless of season., This gives a seasonal energy split directly proportional to the number of days in the season (.25,.33, and .42 for winter, summer, and fall/spring). The sensitivity case assumes a larger winter and smaller summer share (.35 to . 23 to .42$)$.

Results: The results are insensitive to this seasonal energy split. There is almost no change from the base case in any category. 
Tabie F-9

RESULTS OF SENSITIVITY CASE 7

SUMMER-WINTER SHIFT IN SEASONAL SPLIT, RESIDENTIAL WATER HEAT

$$
\left(10^{12} \mathrm{Btu} / \mathrm{Yr}\right)
$$

a. North Central Region

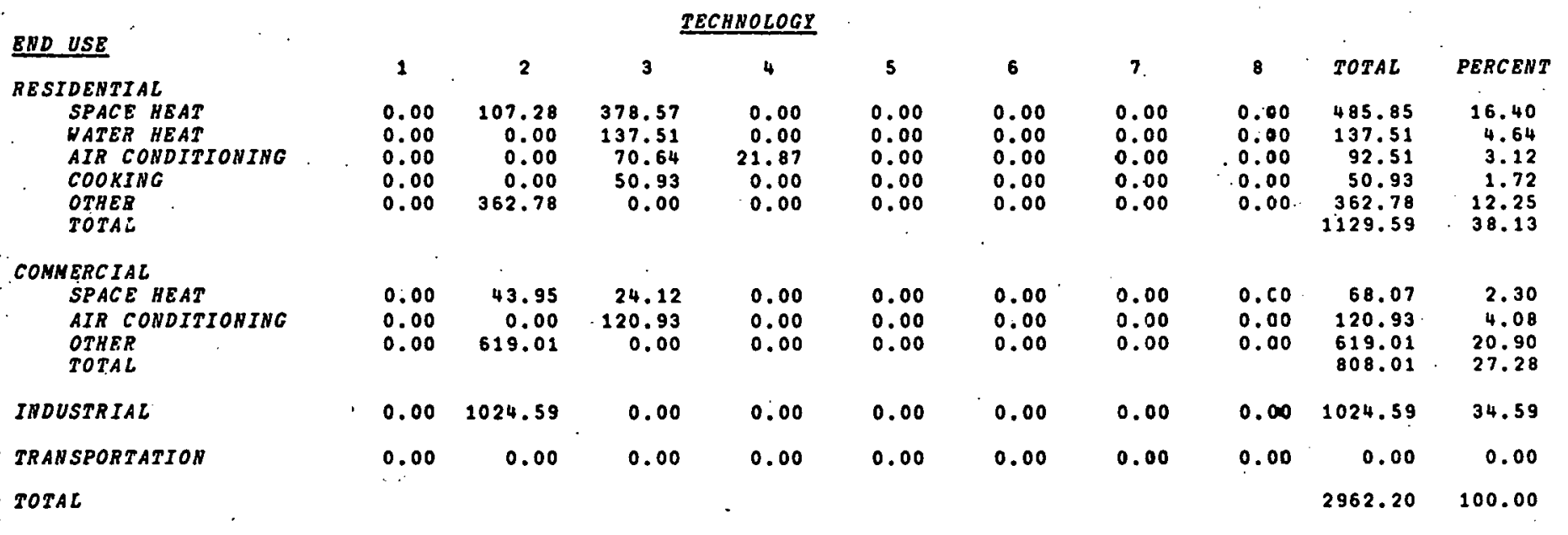

SUMHARY OUTPUTS - - NORTH CENTRAL 2000 12/18/79
SUMMER $\rightarrow$ INTER SHIFT IN SEASONAL SPLIT.RESIDENTIAL WATER HBAT

\begin{tabular}{|c|c|c|c|c|c|c|c|c|c|c|c|c|}
\hline & WINTER & $\begin{array}{l}\text { LOAD FAC } \\
\text { SUMMER }\end{array}$ & $\begin{array}{l}\text { TORS } \\
\text { AUT / SPR }\end{array}$ & $A N N U A L$ & $\begin{array}{l}\text { SEASONAL } \\
\text { SUM/WIN }\end{array}$ & $\begin{array}{l}\text { PBAK RATIOS } \\
\text { I. SPR/WIN }\end{array}$ & $\begin{array}{l}\text { GROWTH } \\
\text { ENERGY }\end{array}$ & $\begin{array}{r}\text { RATES } \\
\text { PEAK }\end{array}$ & $\begin{array}{c}\text { CUMULATIVE } \\
15\end{array}$ & $\begin{array}{c}\angle O A D \\
30\end{array}$ & $\begin{array}{c}B Y . C A P A C I T Y \\
50\end{array}$ & $\begin{array}{c}\text { EACTOR } \\
70\end{array}$ \\
\hline BASE CASE & 0.652 & 0.516 & 0.788 & 0.546 & 1.041 & 0.688 & 2.84 & 3.13 & 0.300 & 0.370 & 0.430 & 0.540 \\
\hline SCENARIO & 0.656 & 0.513 & 0.787 & 0.550 & 1.022 & 0.681 & 2.84 & 3.08 & 0.290 & 0.370 & 0.430 & 0.540 \\
\hline DIPFERENCE & 0.004 & -0.003 & -0.001 & 0.004 & -0.019 & -0.007 & 0.00 & -0.04 & -0.010 & 0.000 & 0.000 & 0.000 \\
\hline PERCENTACE & 0.7 & -0.6 & -0.1 & 0.8 & -1.8 & -1.0 & 0.0 & -1.3 & -3.3 & 0.0 & 0.0 & 0.0 \\
\hline
\end{tabular}


Table F-9, Continued

b. South Central Region

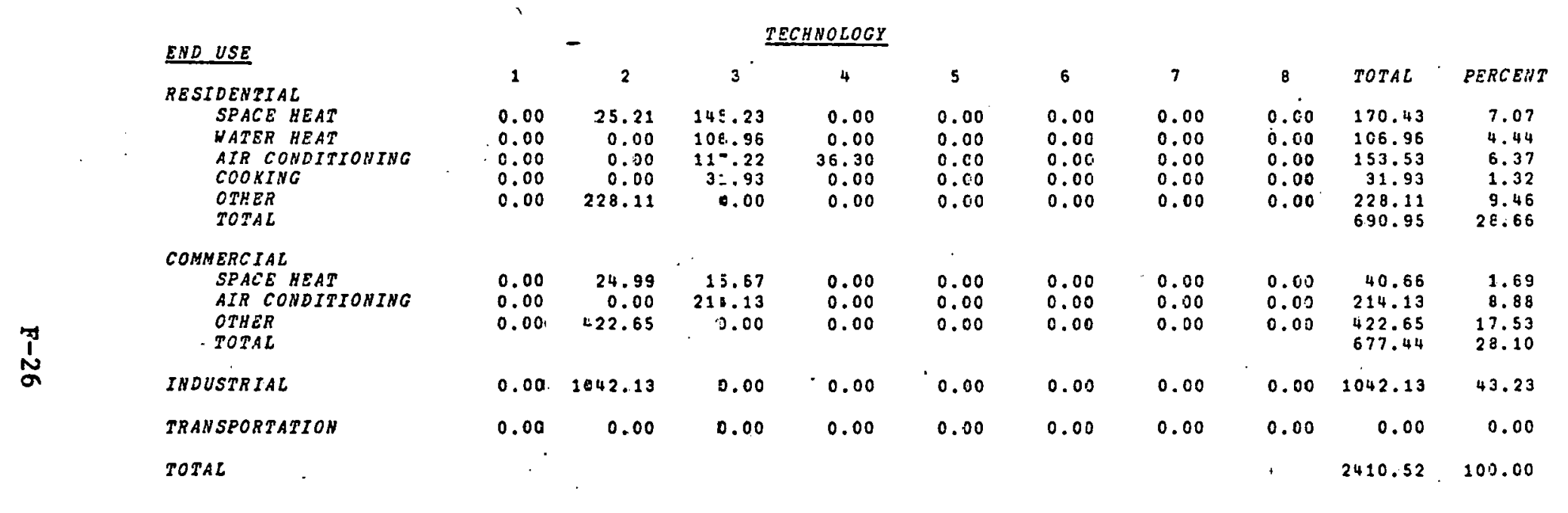

SUMNARY OUTPUTS -- SOUTH CENTRAL 2000 12/18/79

SUMMER $\rightarrow$ WNTER SHIET IN SEASONAL SPLIT RESIDENTEAL WATER HEAT

\begin{tabular}{|c|c|c|c|c|c|}
\hline & & & LOAD PAC & TORS & \\
\hline & & WINTER & SUMMEI & $A U T / S P R$ & ANNEAL \\
\hline BASE CASE & & 0.667 & 0.526 & 0.743 & 0.421 \\
\hline SCENARIO & & 0.671 & 0.524 & $c .744$ & 0.474 \\
\hline DIFFERENCE & & 0.004 & -0.003. & 0.000 & 0.033 \\
\hline PERCENTACE & & 0.6 & -0.5 & 0.0 & 0.7 \\
\hline
\end{tabular}

$\begin{array}{cc}\text { SEASONAL PEAK RATIOS } \\ \text { SUMIWIN } \\ \text { SPRIWIN } \\ 1.425 & 0.823 \\ 1.399 & 0.814 \\ -0.025 & -0.009 \\ -1.8 & -1.1\end{array}$

GROATH RATES GNEROY PEAX

3.123 .68

3.123 .64

$0.00 \quad-0.03$

$0.0 \quad-0.9$
CUMULATIVE LOAD BY CAPACITY PACTOR 15.3050 70

$\begin{array}{llll}0.400 & 0.450 & 0.520 & 0.630\end{array}$

$\begin{array}{llll}0.400 & 0.440 & 0.510 & 0.630\end{array}$

$\begin{array}{llll}0.000 & -0.010 & -0.010 & 0.000\end{array}$

$\begin{array}{llll}0.0 & -2.2 & -1.9 & 0.0\end{array}$ 
Case 8: Heat Pumps in Place of Resistance Space Heaters for New Residential Installations

Assumptions: New installations of electric space heat in the residential sector are assumed to be heat pumps rather than resistance. New residential space heat installations are $50 \%$ heat pump and $50 \%$ gas/oil rather than $50 \%$ electric resistance and $50 \%$ gas/oil as in the base case.

Results:. The winter load factor increases by $4 \%$, but the annual load factor drops by about $4 \%$. This is caused primarily by the higher efficiency of heat. pumps which lowers the winter peak relative to the summer peak. The energy requirement of heat pumps is about $30 \%$ less than resistance resulting in a decrease of $7 \%$ in energy growth rate. 
Table F-10

RESULTS OF SENSITIVITY CASE 8

HEAT PUMP, RESIDENTIAL SPACE HEAT

$$
\left(10^{12}\right. \text { Btu/Yr) }
$$

a. North Central Region

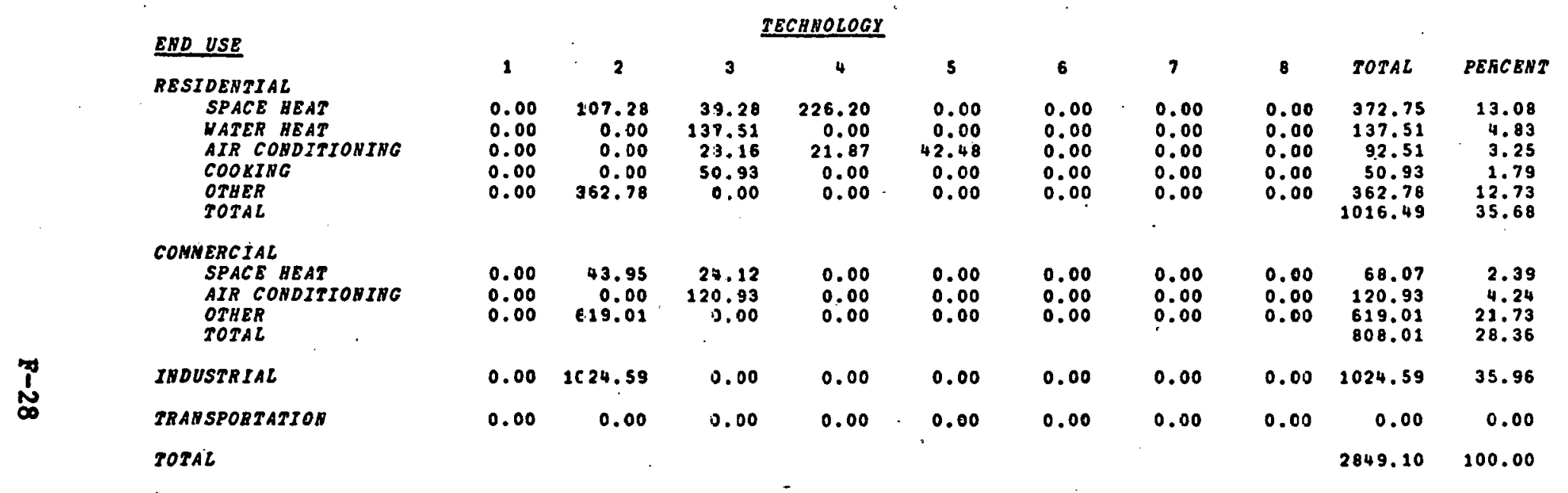

SUMNARY OUTPUTS -. NORTH CENTRAL 2000 12/18/T9 BEAT PUNP,RESIDENTIAL SPACB HEAT

\begin{tabular}{|c|c|c|c|c|c|c|c|c|c|c|c|c|}
\hline & NINTER & $\begin{array}{c}\angle O A D P A C \\
\text { SUMMER }\end{array}$ & $\begin{array}{l}\text { CTORS } \\
\text { AUT / SPR }\end{array}$ & ANDUAL & $\begin{array}{l}\text { SEASONAL } \\
\text { SUM/WIN }\end{array}$ & $\begin{array}{c}P E A K \text { RATIOS } \\
\text { SPR /WIN }\end{array}$ & $\begin{array}{l}\text { GROKTH } \\
\text { ENERCY }\end{array}$ & $\begin{array}{l}\text { RATES } \\
\text { PEAK }\end{array}$ & $\begin{array}{c}\text { CUNULATIVE } \\
15\end{array}$ & $\begin{array}{c}\angle O A D \\
30\end{array}$ & $\begin{array}{c}B Y \text { CAPACITY } \\
50\end{array}$ & $\begin{array}{c}\text { FACTOR } \\
70\end{array}$ \\
\hline BASE CASE & 0.652 & 0.516 & 0.788 & 0.546 & 1.041 & 0.688 & 2.86 & 3.13 & 0.300 & 0.370 & 0.430 & 0.540 \\
\hline SCENARTO & 0.678 & 0.516 & 0.752 & 0.525 & 1.167 & 0.771 & 2.62 & 3.13 & 0.320 & 0.380 & 0.460 & 0.560 \\
\hline DIPFEREHCE & 0.026 & 0.000 & -0.036 & -0.021 & 0.126 & 0.083 & -0.20 & 0.00 & 0.020 & 0.010 & 0.030 & 0.020 \\
\hline PERCENTAGE & 4.0 & 0.0 & -4.5 & -3.0 & 12.1 & 12.1 & 7.0 & 0.0 & 6.7 & 2.7 & 7.0 & 3.7 \\
\hline
\end{tabular}


Table F-10, Continued

b. South Central Region

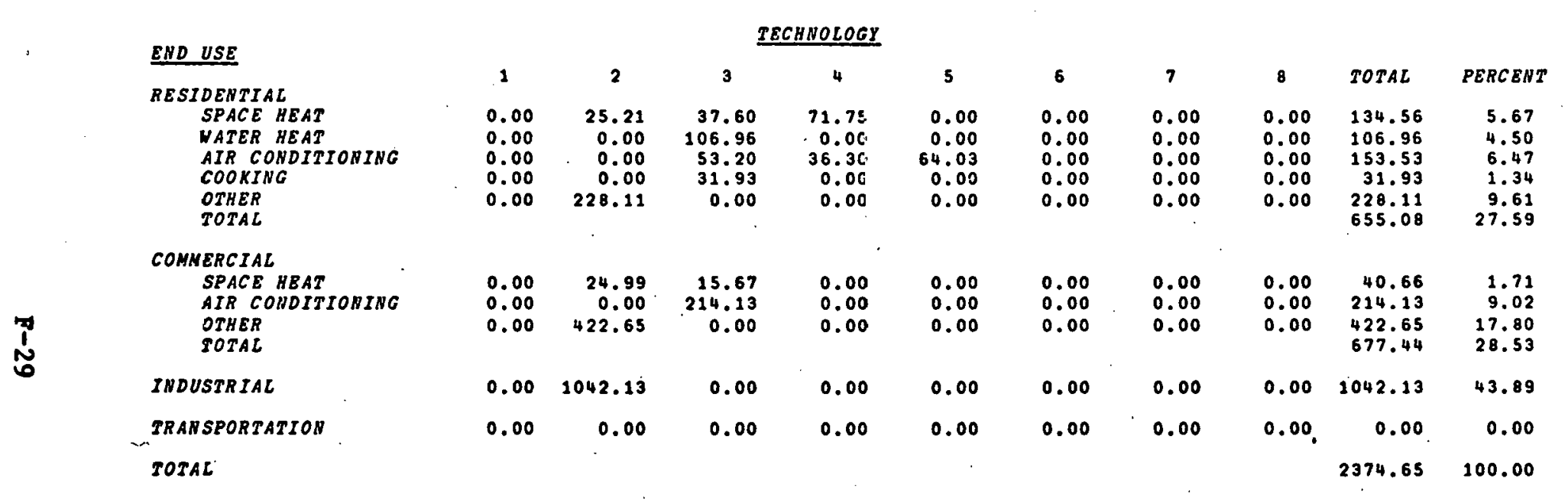

SUMMARY OUTPUTS -- SOUTH CENTRAL $2000 \quad 12 / 18 / 79$ HEAT PUNP.RESIDENTIAL SPACB EEAT

\section{SEASONAL PEAK RATIOS SUH/HIN SPR/WIN}

1.425

1.526

0.823

SCENARJO

DIPFERENCE

PERCEATAGE
0.667

0.687

0.525

0.735

0.465

3.0
0.102

0.882

7.1

0.059

7.1
GBOWTH RATES ENERGY PEAK

3.12

3.04

3.68

$-0.08$

$-0.08$

0.00
CUMULATIVE LOAD BY CAPACITY FACTOR

$\begin{array}{cccc}15 & 30 & 50 & 70 \\ 0.400 & 0.450 & 0.520 & 0.630 \\ 0.390 & 0.450 & 0.530 & 0.650 \\ 0.010 & 0.000 & 0.010 & 0.020 \\ -2.5 & 0.0 & 1.9 & 3.2\end{array}$


Case 9: High Replacement Share for Electric Resistance Space Heat in Residential Sector

Assumptions: Twenty percent of replacements of gas/oil furnaces in the residential sector are converted to electric resistance. Base case assumed no electric conversions.

Results: $\quad$ The system becomes strongly winter peaking with a $23 \%$ reduction in the ratio between summer and winter peaks. Along with this, the annual load factor drops by $12 \%$ and the growth rate of peak demand increases by $37 \%$. All of these changes are the maximum among all sensitivity cases. Clearly, future electricity demands are very sensitive to electric space heat replacements. 
Table F-11

RESULTS OF SENSITIVITY CASE 9

RESIDENTIAL SPACE HEAT REPLACEMENTS $=0.20$

$\left(10^{12_{B}} \mathrm{BU} / \mathrm{Yr}_{\mathrm{r}}\right)$

a. North Central Region

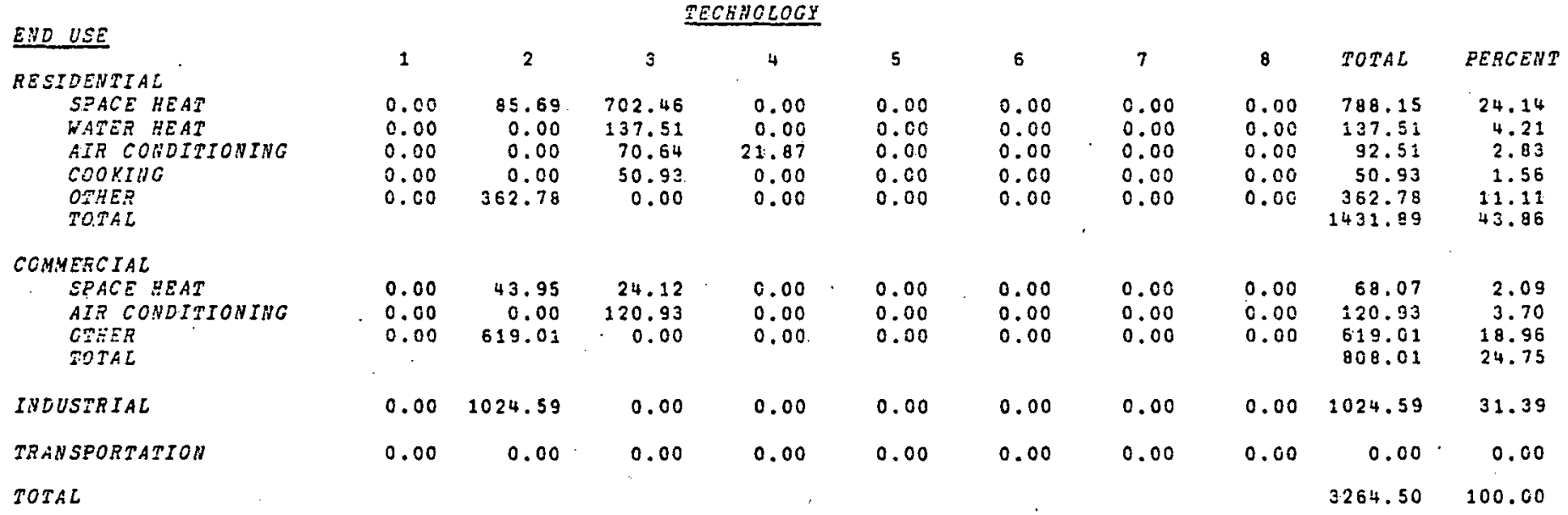

SUMMARY OUTPUTS -- NORTH CENTRAL $200012118 / 79$
RESIDENTIAL SPACE GEAT REPLACEMENTS $=0.20$

LCAD EACTORS
WINTER SUMMER AUT/SPR ANNUAL

BASE CASE

SCEUARTO

DTERERENCE

PERCENTAGE
$0.652 \cdot 0.516 \quad 0.788 \quad 0.546$

$\begin{array}{lllll}0.597 & 0.516 & 0.783 & 0.479\end{array}$

$\begin{array}{lllll}0.055 & -0.001 & -0.005 & -0.065\end{array}$

$\begin{array}{llll}-8.4 & -0.2 & -0.6 & -12.1\end{array}$
SEASONAL FEAK RATIOS SUM/WIN SPR/WIN

1.0410 .688

$0.800 \quad 0.593$

$\begin{aligned}-0.241 & -0.095\end{aligned}$

$-23.2-13.8$

\section{CROHTH RATES} EHERGY PEAK

$2.84 \quad 3.13$

$3.34 \quad 4.28$

$0.50 \quad 1.16$

$37.7 \quad 37.1$ $\begin{array}{cccc}\text { CUMULATIVE } & \text { LOAD EY CAFACITY FACTOR } \\ 15 & 30 & 50 & 70\end{array}$

$\begin{array}{llll}0.300 & 0.370 & 0.430 & 0.540\end{array}$

$\begin{array}{lllll}0.400 & 0.440 & 0.500 & 0.590\end{array}$

$\begin{array}{llll}0.100 & 0.070 & 0.070 & 0.050\end{array}$

$33.3 \quad 18.9 \quad 16.3 \quad 9.3$ 
Table F-11, Continued

b. South Central Region

END USE

RESIDENTIAL

SPACE HEAT
WATER HEAT

WATER HEAT
AIR CONDITIONINO

OTHER

TOTAL

COMMERCIAL

SPACE HEAT

AIR CONDITIONING

OTHER

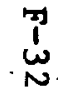

INDUSTRIAL

TRANSPORTATION

TOTAL

\begin{tabular}{|c|c|c|c|c|c|c|c|c|c|}
\hline 1 & 2 & 3 & 4 & 5 & 6 & 7 & B & TOTAL & PERCENT \\
\hline $\begin{array}{l}0.00 \\
0.00 \\
0.00 \\
0.00\end{array}$ & $\begin{array}{r}20.38 \\
0.00 \\
0.00 \\
0.00\end{array}$ & $\begin{array}{r}217.68 \\
106.96 \\
117.22 \\
31.93\end{array}$ & $\begin{array}{r}0.00 \\
0.00 \\
36.30 \\
0.00\end{array}$ & $\begin{array}{l}0.00 \\
0.00 \\
0.00 \\
0.00\end{array}$ & $\begin{array}{l}0.00 \\
0.00 \\
0.00 \\
0.00\end{array}$ & $\begin{array}{l}0.00 \\
0.00 \\
0.00 \\
0.00\end{array}$ & $\begin{array}{l}0.00 \\
0.00 \\
0.00 \\
0.00\end{array}$ & $\begin{array}{r}238.05 \\
106.96 \\
153.53 \\
31.93\end{array}$ & $\begin{array}{l}9.61 \\
4.32 \\
6.20 \\
1.29\end{array}$ \\
\hline 0.00 & 228.11 & 0.00 & 0.00 & 0.00 & 0.00 & 0.00 & 0.00 & $\begin{array}{l}228.11 \\
758.57\end{array}$ & $\begin{array}{r}9.20 \\
30.61\end{array}$ \\
\hline $\begin{array}{l}0.00 \\
0.00 \\
0.00\end{array}$ & $\begin{array}{r}24.99 \\
0.00 \\
422.65\end{array}$ & $\begin{array}{r}15.67 \\
214.13 \\
0.00\end{array}$ & $\begin{array}{l}0.00 \\
0.00 \\
0.00\end{array}$ & $\begin{array}{l}0.00 \\
0.00 \\
0.00\end{array}$ & $\begin{array}{l}0.00 \\
0.00 \\
0.00\end{array}$ & $\begin{array}{l}0.00 \\
0.00 \\
0.00\end{array}$ & $\begin{array}{l}0.00 \\
0.00 \\
0.00\end{array}$ & $\begin{array}{r}40.66 \\
214.13 \\
422.65 \\
677.44\end{array}$ & $\begin{array}{r}1.64 \\
8.64 \\
17.06 \\
27.34\end{array}$ \\
\hline 0.00 & 1042.13 & 0.00 & 0.00 & 0.00 & 0.00 & 0.00 & 0.00 & 1042.13 & 42.05 \\
\hline 0.00 & 0.00 & 0.00 & 0.00 & 0.00 & 0.00 & 0.00 & 0.09 & $\begin{array}{r}0.00 \\
2478.14\end{array}$ & $\begin{array}{r}0.00 \\
100.00\end{array}$ \\
\hline
\end{tabular}

SUNMARY OUTPUTS -- SOUTH CENTRAL 2000 12/18/7S

RESIDENTIAL SPACE HEAT REPLACEMENTS $=0.20$

\begin{tabular}{|c|c|c|c|c|c|c|c|c|c|c|c|c|}
\hline & WINTER & $\begin{array}{c}\angle O A D F A C \\
\text { SUMAER }\end{array}$ & $\begin{array}{l}\text { TORS } \\
\text { AUS / SPR }\end{array}$ & ANNUAL & $\begin{array}{l}\text { SEASONAL } \\
\text { SUM /WIN }\end{array}$ & $\begin{array}{l}\text { PEAK RATIOS } \\
\text { SPR/WIN }\end{array}$ & $\begin{array}{l}\text { GROWIA } \\
\text { EREREI }\end{array}$ & $\begin{array}{l}\text { RATES } \\
\text { PEAK }\end{array}$ & $\underset{15}{\text { CUMULATIV }}$ & $\begin{array}{c}\text { SE LOAD } \\
30\end{array}$ & $\begin{array}{c}B Y \text { CAPACITY } \\
50\end{array}$ & $\begin{array}{c}\text { PACTOR } \\
70\end{array}$ \\
\hline$B A S E$ CASE & 0.667 & 0.526 & 0.743 & 0.471 & 1.425 & 0.823 & 3.12 & 3.68 & 0.400 & 0.450 & 0.520 & 0.630 \\
\hline SCENARIO & 0.628 & $0: 526$ & 0.753 & 0.482 & 1.246 & 0.728 & 3.26 & 3.68 & 0.390 & 0.440 & 0.510 & 0.610 \\
\hline DIFFERENCE & -0.040 & 0.000 & 0.010 & 0.013 & -0.179 & -0.095 & 0.14 & 0.00 & -0.010 & -0.010 & -0.010 & -0.020 \\
\hline PERCENTAGE & -5.9 & 0.0 & 1.3 & 2.8 & -12.6 & -11.6 & 4.6 & 0.0 & -2.5 & -2.2 & -1.9 & -3.2 \\
\hline
\end{tabular}


Case 10: High Electric Resistance Penetration in Commercial Space Heat

Assumptions: The share of electric resistance in new commercial space heat installations is increased from the base case ( $20 \%$ vs. $6 \%$ ). All other installations are assumed to be gas/oil.

Results: The changes are small compared with other sensitivity cases. However, the annual load factor does increase slightly and the system becomes even more seasonally balanced. 
Table F-12

RESULTS OF SENSITIVITY CASE 10

HIGH COMMERCIAL SPACE HEAT PENETRAFION

$$
\left(10^{12} \mathrm{BtU} / \mathrm{Yr}\right)
$$

a. North Central Region

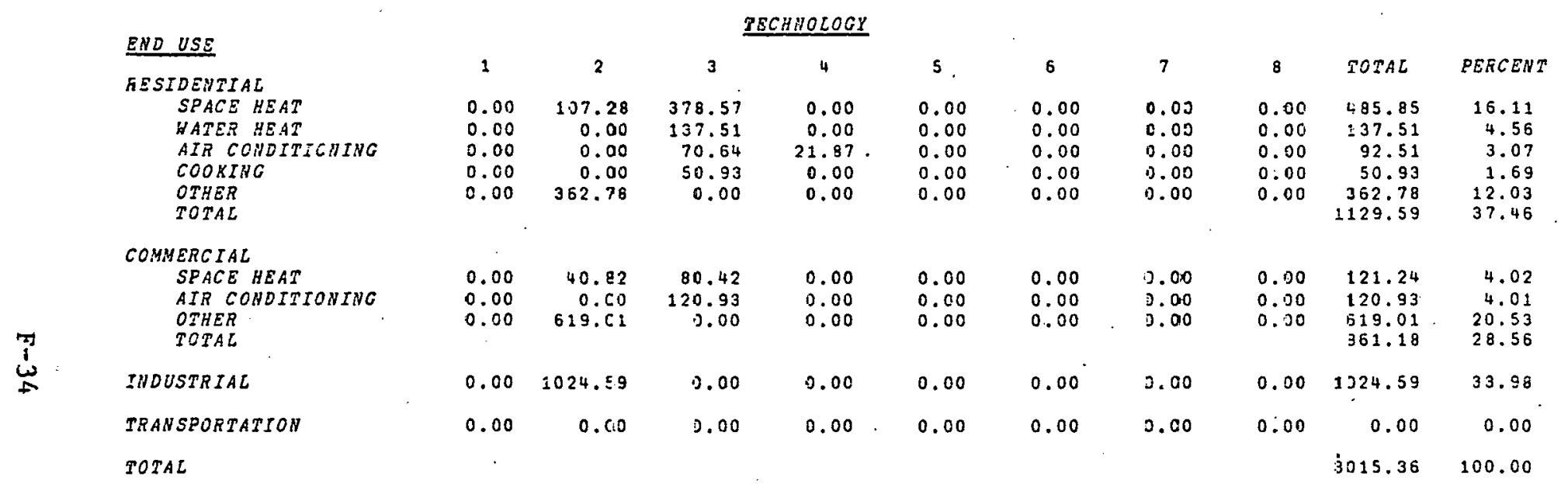

SUMYARY OUTEUTS -- WORTH CENTRAL 2000 12/18/79 HIGA COMHERCIAL SPACE HEAT PENETRATIOH

\begin{tabular}{|c|c|c|c|c|c|c|c|c|c|c|c|c|c|}
\hline & WINTER & $\begin{array}{l}\text { LOAD FAC } \\
\text { SUMAER }\end{array}$ & $\begin{array}{l}\text { TORS } \\
A U S / S=R\end{array}$ & ANNUAL & $\begin{array}{l}\text { SEASONAL } \\
\text { SUM/NIE }\end{array}$ & $\begin{array}{c}\text { FEAK RATIOS } \\
\text { SPR /WI! }\end{array}$ & $\begin{array}{l}\text { GROWTH } \\
\text { EIVERGY }\end{array}$ & $\begin{array}{l}\text { PATES } \\
\text { EEAK }\end{array}$ & $\begin{array}{l}\text { SUAUULATIV } \\
15\end{array}$ & $\begin{array}{c}E \angle O A D \\
30\end{array}$ & $B Y$ & $\begin{array}{l}\text { CAPACITY } \\
50\end{array}$ & $\begin{array}{c}\text { FACTOR } \\
70\end{array}$ \\
\hline$B A S E$ CASE & 0.652 & 0.516 & 0.788 & 0.546 & 1.041 & 0.628 & 2.84 & 3.13 & 0.300 & 0.370 & & 0.430 & 0.540 \\
\hline SCEVARIO & 0.642 & 0.517 & 0.794 & 0.550 & 0.991 & 0.662 & 2.93 & $\Xi .17$ & 0.290 & 0.360 & & 0.430 & 0.540 \\
\hline DIPRERENCE & -0.010 & 0.000 & 0.005 & 0.005 & -0.050 & -0.025 & 0.0 .9 & 0.05 & -0.010 & -0.010 & & 0.000 & 0.000 \\
\hline PERCENTAGE & -1.5 & 0.0 & 0.7 & 0.8 & -4.8 & -3.7 & 3.2 & 1.5 & -3.3 & -2.7 & & 0.0 & 0.0 \\
\hline
\end{tabular}


Table F-12, Continued

b. South Central Region

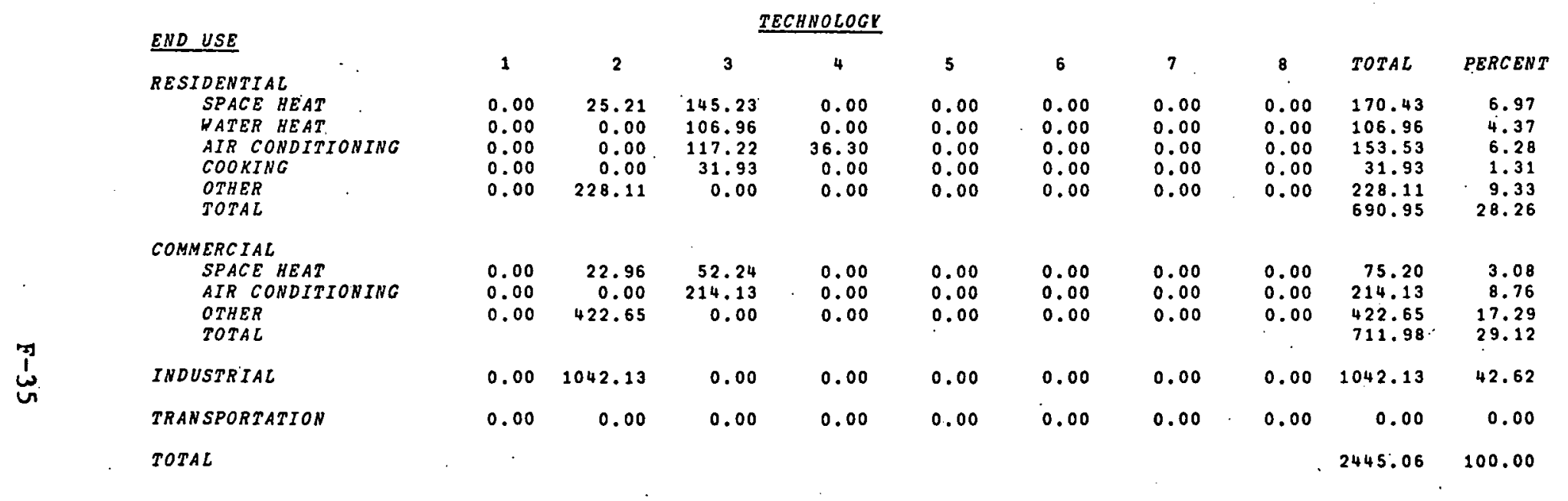

SUMMARY OUTPUTS -- SOUTH CENTRAL 2000

HIGH COMMERCIAL SPACE HEAT PENETRATION

$12 / 18 / 79$

LOAD FACTORS

WINTER SUMMER AUT/SPR ANWUAL

$\begin{array}{llll}0.667 & 0.526 & 0.743 & 0.471\end{array}$

BASE CASE

SCENARIO

DIFFERENCE

$\begin{array}{llll}0.647 & 0.526 & 0.748 & 0.478\end{array}$

PERCENTAGE $\begin{array}{lllll}-0.020 & 0.000 & 0.004 & 0.007\end{array}$

$\begin{array}{rrrr}-3.0 & 0.0 & 0.6 & 1.5\end{array}$

SEASOHAL PEAK RATIOS SUMIWIN SRR/WIN

$\begin{array}{rr}1.425 & 0.823 \\ 1.331 & 0.775 \\ -0.093 & -0.049 \\ -6.5 & -5.9\end{array}$

GROWTH RATES ENERGY PEAX

$3.12 \quad 3.68$

$3.19 \quad 3.68$

$0.07 \quad 0.00$

$2.4 \quad 0.0$
CUNULATIVE LOAD BY CAPACITY FACTOR

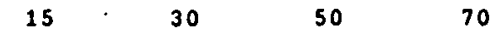

$\begin{array}{llll}0.400 & 0.450 & 0.520 & 0.630\end{array}$

$0.390 \cdot 0.440 \cdot 0.510 \quad 0.630$

$\begin{array}{lllll}-0.010 & -0.010 & -0.010 & 0.000\end{array}$

$\begin{array}{llll}-2.5 & -2.2 & -1.9 & 0.0\end{array}$ 
Case 11: High Replacement Share for Electric Resistance Space Heat in the Commercial Sector

Assumptions: Twenty percent of replacements of gas/oil furnaces in the commercial sector are by electric reststance. Base case assumed no electric replacements.

Results: $\quad$ The results are similar but not so extensive as in Case 9, since there is less energy in commercial than in residential space heat. The system again becomes strongly winter peaking and the annual load factor drops, this time by $6 \%$. 
Table F-13

RESULTS OF SENSITIVITY CASE 11

COMMERCIAL SPACE HEAT REPLACEMENTS $=0.20$

$$
\left(10^{12} \text { Btu/Yr }\right)
$$

\section{a. North Central Region}

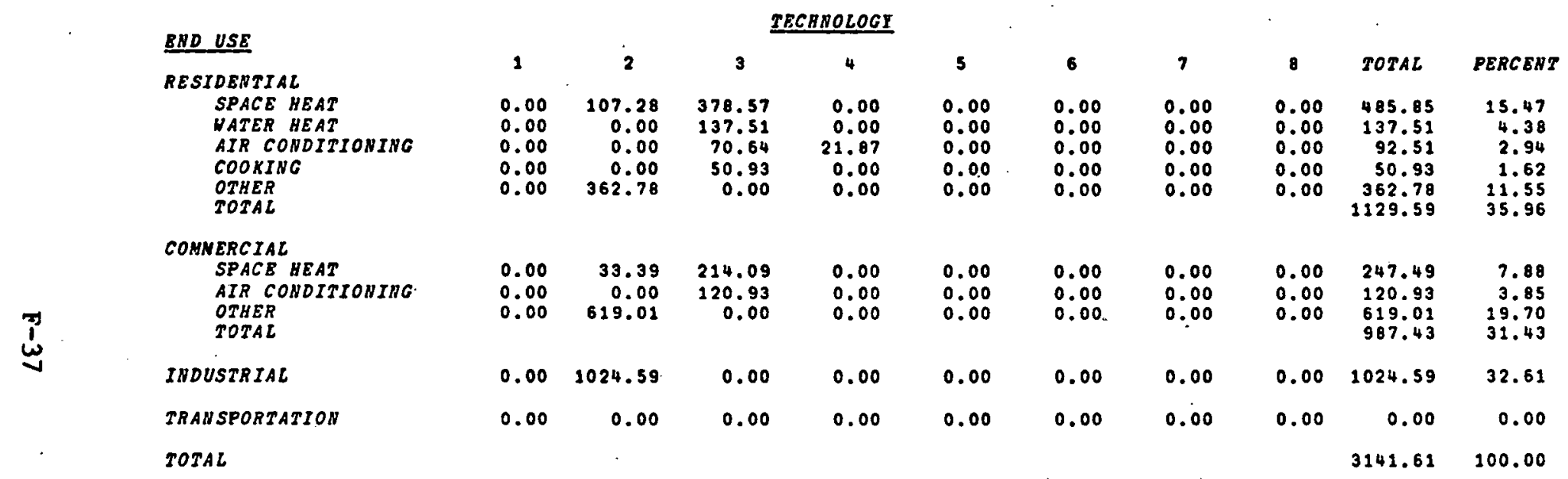

SUMHARY OUTPUTS - - YORTH CENTRAL $200012 / 18 / 79$
COMHERCIAL SPACE GRAT REPLACEMENTS $=0.20$

\begin{tabular}{|c|c|c|c|c|c|c|c|c|c|c|c|c|}
\hline & WIRTER & $\begin{array}{c}\angle O A D F A C \\
\text { SUMHER }\end{array}$ & $\begin{array}{l}\text { TORS } \\
\text { AUT / SPR }\end{array}$ & ARNUAL & $\begin{array}{l}\text { SEASONAL } \\
\text { SUW/WIE }\end{array}$ & $\begin{array}{l}\text { BAK RATIOS } \\
\text { SPR/WIN }\end{array}$ & $\begin{array}{l}\text { GROWTH } \\
\text { BNERGY }\end{array}$ & $\begin{array}{r}R A T E S \\
P E A K\end{array}$ & $\underset{15}{\text { CUNULATIV }}$ & $=\underset{30}{\angle O A D} B Y$ & $\underset{50}{C A P A C I T Y}$ & $\begin{array}{c}\text { EACTOR } \\
70\end{array}$ \\
\hline$B A S E$ CASE & 0.652 & 0.516 & 0.788 & 0.546 & 1.041 & 0.688 & 2.84 & 3.13 & 0.300 & 0.370 & 0.430 & 0.540 \\
\hline SCENARIO & 0.620 & 0.517 & 0.801 & 0.514 & 0.88 .9 & 0.618 & 3.14 & 3.74 & 0.350 & 0.400 & 0.450 & 0.570 \\
\hline DIEPEREACE & -0.032 & 0.000 & 0.013 & -0.032 & -0.152 & -0.070 & 0.30 & 0.61 & 0.050 & 0.030 & 0.020 & 0.030 \\
\hline PERCERTAGE & -4.9 & 0.1 & 1.6 & -5.8 & -14.6 & -10.2 & 10.7 & 19.5 & 16.7 & 0.1 & 4.7 & 5.6 \\
\hline
\end{tabular}


Table F-13, Continued

b. South Central Region

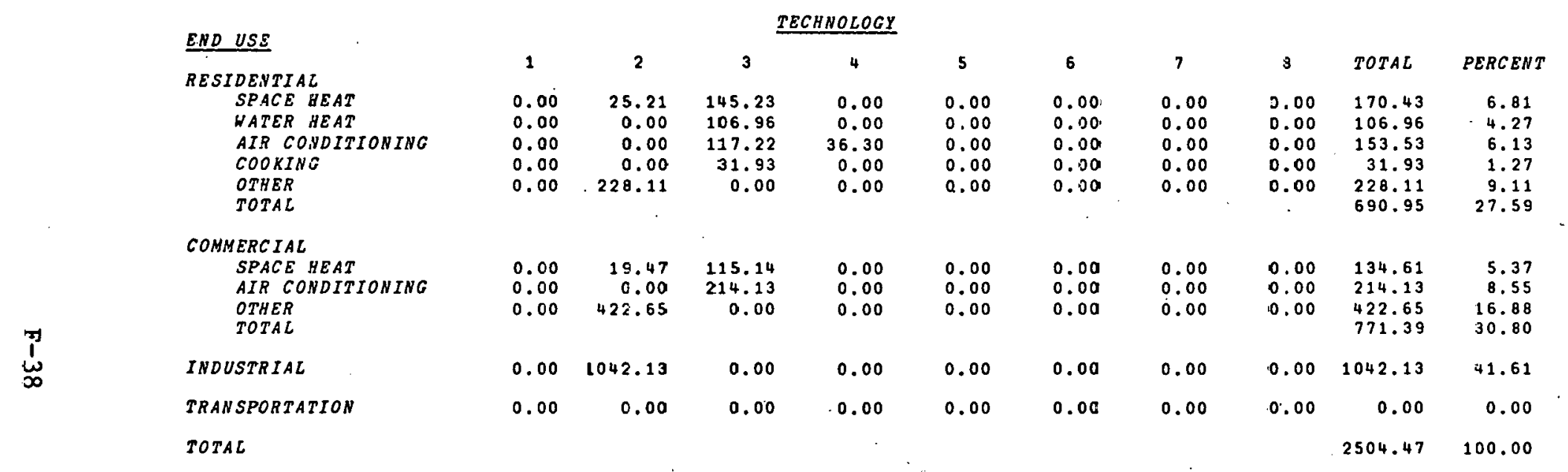

SUMYARY OCTPUTS -- SOUTH CENTRAL 2000 $12 / 18: 79$
COMYERCIAL. SPACE HEAT REPLACEMENTS $=0.20 \%$

\begin{tabular}{|c|c|c|c|c|c|c|c|c|c|c|c|c|}
\hline & WINTER & $\begin{array}{c}\text { LOAD } E A C \\
\text { SUMMER }\end{array}$ & $\begin{array}{l}\text { TORS } \\
\text { AUT / SPR }\end{array}$ & ANIUAL & $\begin{array}{l}\text { SEASONAL } \\
\text { SUM/WIN }\end{array}$ & $\begin{array}{c}E A K \text { RATIOS } \\
\text { SPR / WIN }\end{array}$ & $\begin{array}{l}\text { GRORTH } \\
\text { ENERCY }\end{array}$ & $\begin{array}{r}\text { RATES } \\
\text { PEAK }\end{array}$ & $\begin{array}{c}\text { CUMULATIVE } \\
15\end{array}$ & $\begin{array}{c}E \text { LOAD } \\
30\end{array}$ & $\begin{array}{c}B Y \text { CAPACITY } \\
50\end{array}$ & $\begin{array}{c}Y \text { FACTOR } \\
70\end{array}$ \\
\hline$B A S E$ CASE & 0.667 & 0.526 & 0.743 & 0.471 & 1.425 & 0.823 & 3.12 & 3.68 & 0.400 & 0.450 & 0.520 & 0.630 \\
\hline SCENARIO & 0.619 & 0.525 & 0.756 & 0.490 & 1.197 & 0.705 & 3.32 & 3.68 & 0.350 & 0.420 & 0.500 & 0.620 \\
\hline DIFFERENCE & -0.048 & 0.000 & 0.012 & 0.019 & -0.228 & -0.119 & 0.20 & 0.00 & -0.050 & -0.030 & -0.020 & -0.010 \\
\hline PERCENTACE & -7.2 & 0.0 & 1.6 & 4.0 & -16.0 & -14.4 & 6.3 & 0.0 & -12.5 & -6.7 & -3.8 & -1.6 \\
\hline
\end{tabular}


Case 12: Efficiency Improvement in Commercial Alr Conditioning

Assumptions: Efficiency of commerclal air conditioning is improved by $30 \%$ (from 3.0 to 3.9): No improvement was assumed in the base case.

Results: The key result here is a $7 \%$ decrease in the growth rate of the peak load due to a reduction in the summer peak. The efficiency improvement causes a reduction in the weathersensitive component of summer loads, resulting in a $5 \%$ increase in the summer load factor. This also leads to an Increase in the annual load factor of $3 \%$. 
Table F-14

RESULTS OF SENSITIVITY CASE 12

IMPROVED EFFICIENCY, COMMERCIAL AIR CONDITIONING

$$
\left(10^{12} / \mathrm{Btu} / \mathrm{Yr}\right)
$$

a. North Central Region

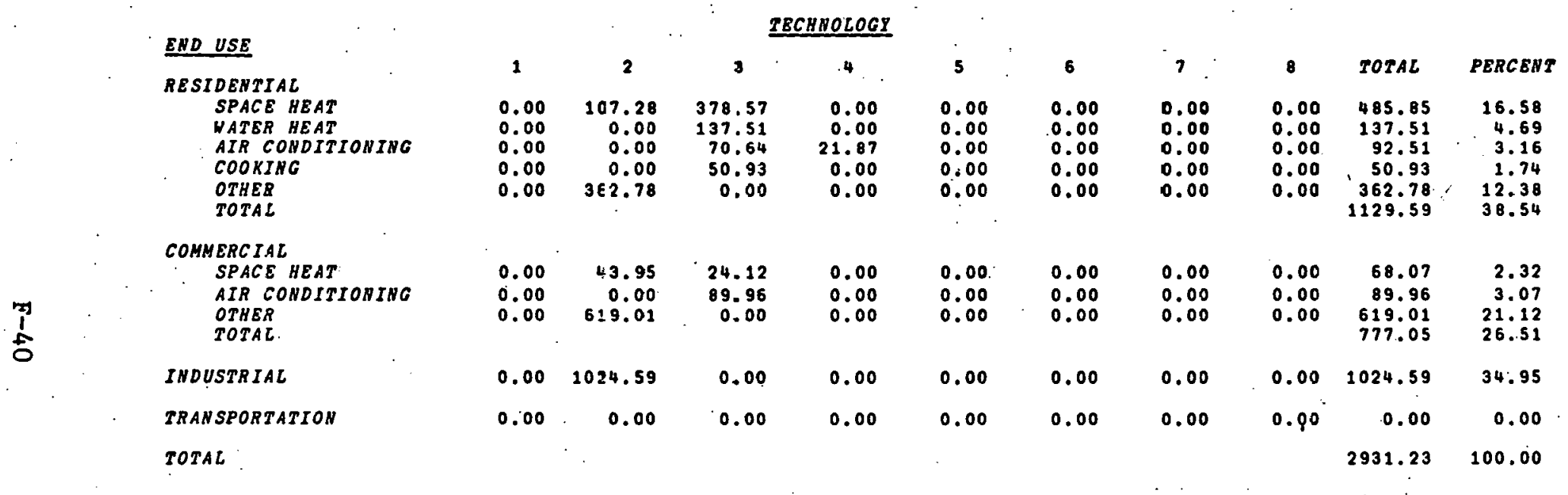

SUMNARY OUTFUTS -- NORTH CBNTRAL 2000'12/18/70

IMPROVED EFEICIENCY, COMNERCIAL AIR CONDITIONING

\begin{tabular}{|c|c|c|c|c|c|c|c|c|c|c|c|c|}
\hline & HIMTER & $\begin{array}{c}\text { LOAD EAC } \\
\text { SUMMER }\end{array}$ & $\begin{array}{l}\text { ETORS } \\
\text { AUS/SPR }\end{array}$ & $A N N U A L$ & $\begin{array}{l}\text { SEASONAL } \\
\text { SUM/WIN }\end{array}$ & $\begin{array}{l}\text { PEAK RATIOS } \\
\text { SPR/WIN }\end{array}$ & $\begin{array}{l}\text { GROWPB } \\
\text { ENEROY }\end{array}$ & $\begin{array}{r}\text { RATES } \\
\text { PEAK }\end{array}$ & $\begin{array}{c}\text { CUMULATIVE } \\
15\end{array}$ & $\begin{array}{c}E O A D \\
30\end{array}$ & $\begin{array}{c}B Y \text { CAPACITY } \\
50\end{array}$ & $\begin{array}{c}\text { PACTOR } \\
70\end{array}$ \\
\hline$B A S B$ CASE & 0.652 & 0.516 & 0.788 & 0.546 & 1.041 & 0.688 & 2.84 & 3.13 & 0.300 & 0.370. & 0.430 & 0.540 \\
\hline SCENARIO & 0.652 & 0.543 & 0.788 & 0.562 & 0.956 & 0.688 & 2.78 & 2.92 & 0.280 & 0.350 & 0.410 & 0.520 \\
\hline DIFPEREHCE & 0.000 & 0.026 & -0.000 & 0.016 & -0.084 & 0.000 & -0.05 & -0.21 & -0.020 & -0.020 & -0.020 & -0.020 \\
\hline PERCENTAGE & 0.1 & 5.1 & -0.1 & 3.0 & -8.1 & 0.0 & -1.9 & -6.6 & -6.7 & -5.4 & -4.7 & -3.7 \\
\hline
\end{tabular}


Table F-14, Continued

b. South Central Region

\begin{tabular}{|c|c|c|c|c|c|c|c|c|c|c|c|}
\hline & \multirow{2}{*}{ END USE } & \multicolumn{6}{|c|}{ TECHNOLOSY } & \multirow[b]{2}{*}{7} & \multirow[b]{2}{*}{8} & \multirow[b]{2}{*}{ TOTAL } & . \\
\hline & & 1 & 2 & 3 & 4 & 5 & 6 & & & & PERCENT \\
\hline & $\begin{array}{l}\text { SPACE HEAT } \\
\text { HAER HEAT } \\
\text { AIR CONDITIONING } \\
\text { COOKING } \\
\text { OOHHER } \\
\text { TOTAL }\end{array}$ & $\begin{array}{l}0.00 \\
0.00 \\
0.00 \\
0.00 \\
0.00\end{array}$ & $\begin{array}{r}25.21 \\
0.00 \\
0.00 \\
0.00 \\
228.11\end{array}$ & $\begin{array}{r}145.23 \\
106.96 \\
117.22 \\
31.93 \\
0.00\end{array}$ & $\begin{array}{r}0.00 \\
0.00 \\
36.30 \\
0.00 \\
0.00\end{array}$ & $\begin{array}{l}0.00 \\
0.00 \\
0.00 \\
0.00 \\
0.00\end{array}$ & $\begin{array}{l}0.00 \\
0.00 \\
0.00 \\
0.00 \\
0.00\end{array}$ & $\begin{array}{l}0.00 \\
0.00 \\
0.00 \\
0.00 \\
0.00\end{array}$ & $\begin{array}{l}0.00 \\
0.00 \\
0.00 \\
0.00 \\
0.00\end{array}$ & $\begin{array}{l}170.43 \\
106.96 \\
153.53 \\
31.93 \\
228.11 \\
690.95\end{array}$ & $\begin{array}{r}7.24 \\
4.54 \\
6.52 \\
1.36 \\
9.69 \\
29.34\end{array}$ \\
\hline$i$ & $\begin{array}{l}\text { COMMERCIAL } \\
\text { SPACE ABAT } \\
\text { AIR CONDITIONING } \\
\text { OOHER } \\
\text { TOTAL }\end{array}$ & $\begin{array}{l}0.00 \\
0.00 \\
0.00\end{array}$ & $\begin{array}{r}24.99 \\
0.00 \\
422.65\end{array}$ & $\begin{array}{r}15.67 \\
158.81 \\
0.00\end{array}$ & $\begin{array}{l}0.00 \\
0.00 \\
0.00\end{array}$ & $\begin{array}{l}0.00 \\
0.00 \\
0.00\end{array}$ & $\begin{array}{l}0.00 \\
0.00 \\
0.00\end{array}$ & $\begin{array}{l}0.00 \\
0.00 \\
0.00\end{array}$ & $\begin{array}{l}0.00 \\
0.00 \\
0.00\end{array}$ & $\begin{array}{r}40.66 \\
158.81 \\
422.65 \\
622.12\end{array}$ & $\begin{array}{r}1.73 \\
6.74 \\
17.95 \\
26.41\end{array}$ \\
\hline & IHDUSTRIAL & 0.00 & 1042.13 & 0.00 & 0.00 & 0.00. & 0.00 & 0.00 & 0.00 & 1042.13 & 44.25 \\
\hline & TRANSPORTATION & 0.00 & 0.00 & 0.00 & 0.00 & 0.00 & 0.00 & 0.00 & 0.00 & 0.00 & 0.00 \\
\hline & TOTAL & & & & & & & & & 2355.20 & 100.00 \\
\hline
\end{tabular}

SUNKARY OUTPUTS -- SOUTH C.ENTRAL $2000 \quad 12 / 18 / 79$ INPROVBD EPPICIBHCP.CONMERCIAL AIR CONDITIOHING

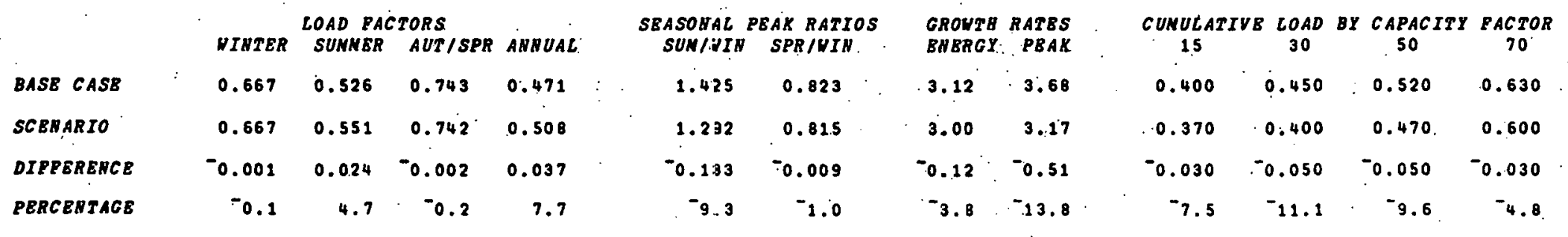


Case 13: Low New Installation Share for Commercial Air Conditioning

Assumptions: Installation share of air conditioning in the commercial sector reduced ( $50 \%$ vs. $90 \%)$. The remainder is assumed not to have air conditioning. This corresponds to historical commercial air conditioning saturations.

Results: The results are very similar to Case 12 in which efficiency was improved by $30 \%$. The reduction in this weather-sensitive load causes a drop in the rate of growth of peak demand and improves the annual load factor. 
Table F-15

RESULTS OF SENSITIVITY CASE 13

LOW SATURATIONS, COMMERCIAL AIR CONDITIONIN:

$$
\left(10^{12} \mathrm{Btu} / \mathrm{Yr}\right)
$$

a. North Central Region

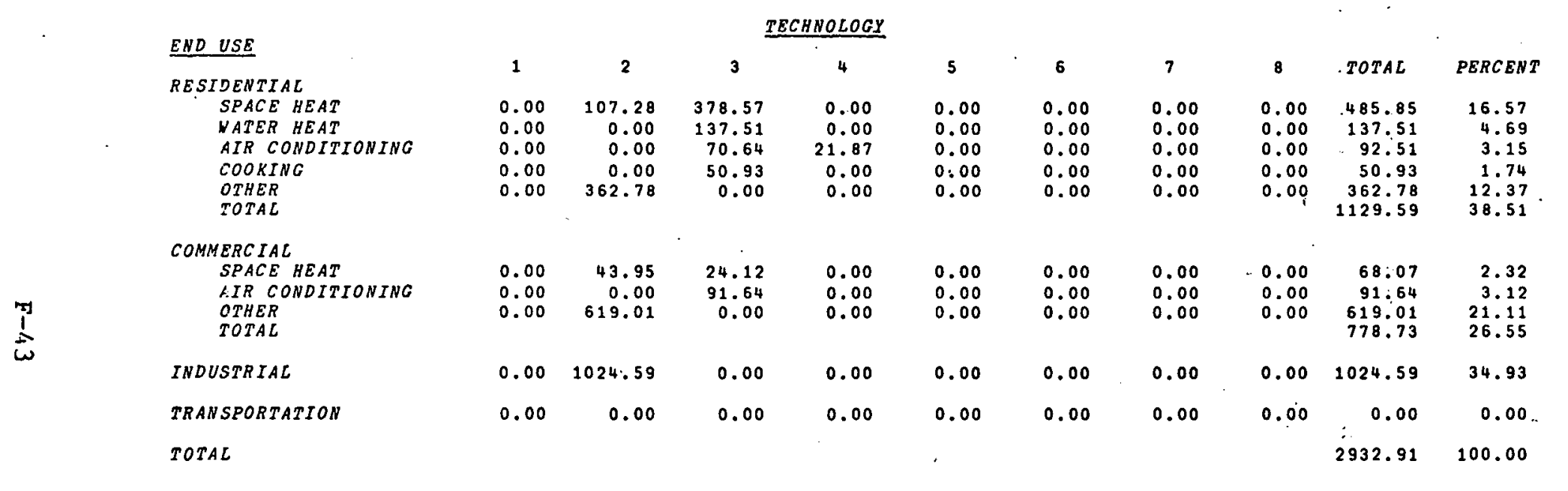

SUMMARY OUTPUTS -- NORTH CENTRAL 2000 12/18/79 LOW SATURATIONS, COMMERCIAL AIR CONDITIONING

\begin{tabular}{|c|c|c|c|c|c|c|c|c|c|c|c|c|}
\hline & WINTER & $\begin{array}{c}\text { LOAD FAC } \\
\text { SUMNER }\end{array}$ & $\begin{array}{l}\text { TORS } \\
\text { AUT / SPR }\end{array}$ & ANNUAL & $\begin{array}{l}\text { SEASONAE } \\
\text { SUM/WIN }\end{array}$ & $\begin{array}{c}\text { PEAK RATIOS } \\
\text { SPR/WIN }\end{array}$ & $\begin{array}{l}\text { GROWTH } \\
\text { ENERGY }\end{array}$ & $\begin{array}{r}\text { RATES } \\
\text { PEAK }\end{array}$ & $\underset{15}{\text { CUNULATIVE }}$ & $E \underset{30}{L O A D}$ & $\begin{array}{c}B Y C A P A C I T Y \\
50\end{array}$ & $\begin{array}{c}\text { Y EACTOR } \\
70\end{array}$ \\
\hline$B A S E$ CASE & 0.652 & 0.516 & 0.788 & 0.546 & 1.041 & 0.688 & 2.04 & 3.13 & 0.300 & 0.370 & 0.430 & 0.540 \\
\hline SCENARIO & 0.652 & 0.542 & 0.788 & 0.562 & 0.961 & 0.688 & 2.79 & 2.92 & 0.280 & 0.350 & 0.410 & 0.520 \\
\hline DIEEERENCE & 0.000 & 0.025 & -0.000 & 0.017 & -0.080 & 0.000 & -0.05 & -0.21 & -0.020 & -0.020 & -0.020 & -0.020 \\
\hline PERCENTACE & 0.1 & 4.9 & -0.1 & 3.1 & -7.7 & 0.0 & -1.8 & -6.6 & -6.7 & -5.4 & -4.7 & -3.7 \\
\hline
\end{tabular}


Table F-15, Continued

\section{b. South Central Region}

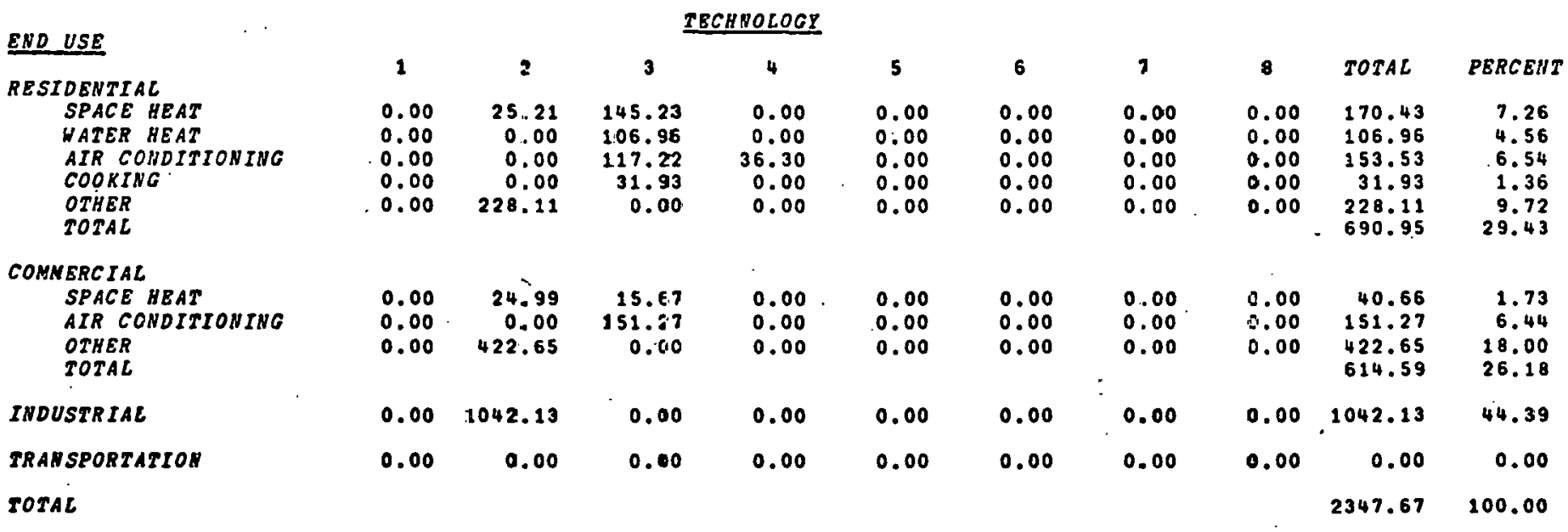

SUNWARY OUTPUTS -- SOUTH CERTRAC 2000 12/18/79

LOH SATURATIOUS, CDNNERCIAL AIR COMDITIORING

\begin{tabular}{|c|c|c|c|c|c|c|c|c|c|c|c|c|}
\hline & WIATER & $\begin{array}{l}\text { COAD EAC } \\
\text { SUNMBR }\end{array}$ & $\begin{array}{l}\text { LORS } \\
\text { AUT.PSPR }\end{array}$ & AMNUAL & $\begin{array}{l}\text { SBASOHAL } \\
\text { SUM/WIA }\end{array}$ & $\begin{array}{l}\text { PEAR RATLOS } \\
\text { SPR /WIE }\end{array}$ & $\begin{array}{l}\text { GRONTE } \\
\text { ENARGT }\end{array}$ & $\begin{array}{r}\text { RATES } \\
\text { PEAK }\end{array}$ & $\begin{array}{c}\text { CUNULATIVE } \\
15\end{array}$ & $\begin{array}{c}E . \angle O A D \\
30\end{array}$ & $\begin{array}{c}\text { BY CAPACITY } \\
50\end{array}$ & $\begin{array}{c}\text { PACTOR } \\
70\end{array}$ \\
\hline BASB CASB & 0.667 & 0.526 & $0.7 \% 3$ & 0.471 & 1.425 & 0.823 & 3.12 & 3.68 & 0.400 & 0.450 & 0.520 & 0.630 \\
\hline SCENARIO & 0.667 & 0.558 & $0.7+3$ & 0.513 & 1.274 & 0.814 & 2.98 & 3.10 & 0.360 & 0.390 & 0.470 & 0.600 \\
\hline DIPPBREMCE & 0.000 & 0.029 & -0.000 & 0.042 & -0.151 & -0.010 & -0.24 & -0.50 & -0.040 & -0.060 & -0.050 & -0.030 \\
\hline PERCEUTACE & 0.0 & 5.6 & -0.1 & 9.0 & -10.6 & -1.2 & -4.4 & -15.8 & -10.0 & -13.3 & -9.6 & -4.8 \\
\hline
\end{tabular}


Case 14: Low Installation Rate of Residential Air Conditioning

Assumptions: Installation share of no appliance, central a/c, and room a/c is assumed to be the same as the 1972 distribution $(.65, .12$, and .23 , respectively, in North Central, rather than the base case values .2, .6, and .2; in South Central .38, .24, and .38 vs . $2, .6$, and .2).

Results: The system becomes slightly winter peaking with a reduction of about $8 \%$ in the summer over winter peak ratio. The growth rate of peak load is reduced by about $7 \%$, and the annual load factor is increased by $3 \%$. These effects are caused partly by a reduction in the weather-sensitive air conditioning load and partly by the higher load factor of room air conditioners compared with central. 
Table F-16

RESULTS OF SENSITIVITY CASE 14

HISTORICAL SATURATIONS, RESIDENTIAL AIR CONDITIONING

$$
\left(10^{12} \mathrm{Btu} / \mathrm{Yr}\right) \text {. }
$$

a. North Central Region

\section{END USE}

RESIDENTIAL

SPACE HEAT

WATER HEAT

AIR CONDITIONING

COOKING

OTHER
TOTAL

COMNERCIAL

SPACE HEAT

AIR COLDITIONINO

OTHER
TOTAL

$\frac{1}{1}$
INDUSTRIAL

TRAN SPORTATION

TOTAL
TECHNOLOGY

1
0.00
0.00
0.00
0.00
0.00

\section{2}

\subsection{8}

0.00

0.00

362.78

3
378.5
137.51
29.86
50.95
0.06

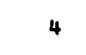

0.00

0.00
0.00

22.89
0.00

0.00
0.00

5
0.00
0.00
0.00
0.00
0.00

\section{6}

0.00
0.00

0.00
0.00
0.00

0.00

0.00

0.00

0.00
0.00
0.00

43.95

24.12

120.93

0.00
0.00
0.00

0.00
0.00

0.00

0.000
0.00

0.00

0.00

0.00

$0.00 \quad 1024.59$

0.013

0.00

0.00

0.00

0.00

0.00

0.00

0.03

0.00

0.00

.

.

\begin{tabular}{ccrc}
7 & \multicolumn{1}{c}{ TOTAL } & PERCENT \\
0.20 & $0.0 \mathrm{C}$ & 485.85 & 16.62 \\
0.30 & $0.0 \mathrm{C}$ & 137.51 & 4.71 \\
0.20 & $0.0 \mathrm{C}$ & 52.76 & 1.81 \\
0.00 & $0.0 \mathrm{C}$ & 50.93 & 1.74 \\
0.30 & $0.0 \mathrm{C}$ & 362.78 & 12.41 \\
& & 1089.83 & 37.29
\end{tabular}

$\begin{array}{llll}0.00 & 0.00 & 68.07 & 2.33\end{array}$

$\begin{array}{llll}0.00 & 0.00 & 120.93 & 4.14\end{array}$

$\begin{array}{lll}0.00 & 619.01 & 21.18 \\ 808.01 & 27.65\end{array}$

$0.00 \quad 1024.59 \quad 35.06$

$0.00 \quad 0.00 \quad 0.00$

$2922.44 \quad 100.00$

SUMNARY OUTPUTS -- NORTH CEMTRAL $2000 \quad 12 / 18 / 79$ HISTORICAL SATURATIONS, RESIDENTIAL AIR CONDITIONING

\begin{tabular}{|c|c|c|c|c|c|c|c|c|c|c|c|c|}
\hline & WINTER & $\begin{array}{c}\text { COAD } F A C \\
\text { SUMAER }\end{array}$ & $\begin{array}{l}\text { TORS } \\
\text { AUT/SPR }\end{array}$ & ANA UAL & $\begin{array}{l}\text { SEASONAL } \\
\text { SUM/WIN }\end{array}$ & $\begin{array}{c}\text { PEAK RATIOS } \\
\text { SPR /WIN }\end{array}$ & $\begin{array}{l}\text { GRONTH } \\
\text { ENEFGY }\end{array}$ & $\begin{array}{r}\text { RATES } \\
\text { PEAK }\end{array}$ & $\underset{15}{\text { CUNULATIVE }}$ & $\begin{array}{c}E C O A D \\
30\end{array}$ & $\begin{array}{c}B Y C A P A C I T Y \\
50\end{array}$ & $\begin{array}{c}Y \text { PACTOR } \\
70\end{array}$ \\
\hline BASR CASE & 0.652 & 0.516 & $0.78 B$ & 0.5 .46 & 1.041 & 0.688 & $2.8 \mathrm{~L}$ & 3.13 & 0.300 & 0.370 & 0.430 & 0.540 \\
\hline SCENARIO & 0.652 & 0.539 & 0.788 & 0.360 & 0.954 & 0.688 & 2.77 & 2.92 & 0.280 & 0.350 & 0.410 & 0.530 \\
\hline DIFEERENCE & 0.000 & 0.023 & -0.000 & 0.014 & -0.087 & 0.000 & -0.07 & -0.21 & -0.020 & -0.020 & -0.020 & -0.010 \\
\hline PERCENTAGE & 0.1 & 4.4 & -0.1 & 2.6 & -8.3 & 0.0 & -2. & -6.6 & -6.7 & -5.4 & -4.7 & -1.9 \\
\hline
\end{tabular}




\section{c. South Central Region}

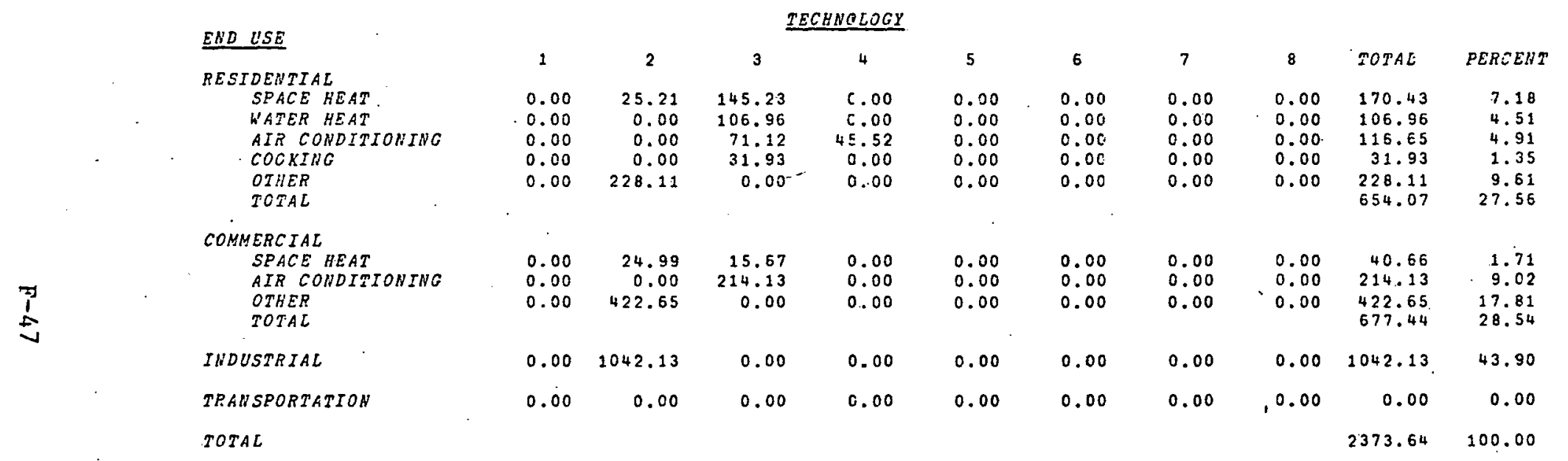

SUMNARY OUTPUTS -- SOUTH CENTRAL 2000 12/18/79 HISTORICAL SATURATIONS, RESIDENTIAL AIR CONDITIONINO

\begin{tabular}{|c|c|c|c|c|c|c|c|c|c|c|c|c|}
\hline & WINTER & $\begin{array}{l}\text { LOAD EAC } \\
\text { SUMMER }\end{array}$ & $\begin{array}{l}\text { TORS } \\
\text { AUT / SPR }\end{array}$ & ALNUAL & $\begin{array}{l}\text { SEASONAL } \\
\text { SUM/WIN }\end{array}$ & $\begin{array}{l}\text { EAR RATIOS } \\
\text { SPR } / W I N\end{array}$ & $\begin{array}{l}\text { GRONTH } \\
\text { ENERGY }\end{array}$ & $\begin{array}{l}\text { RATES } \\
\text { PEAK }\end{array}$ & $\underset{15}{\text { CUNULATIVL }}$ & $\begin{array}{c}E \text { EOAD } \\
30\end{array}$ & $\begin{array}{c}B Y \text { CAPACITY } \\
50\end{array}$ & $\begin{array}{c}Y \text { FACTOR } \\
70\end{array}$ \\
\hline$B A S E . C A S E$ & 0.667 & 0.526 & 0.743 & 0.471 & 1.425 & 0.823 & 3.12 & 3.68 & 0.400 & 0.450 & 0.520 & 0.630 \\
\hline SCENARIO & 0.668. & 0.539 & 0.748 & 0.491 & 1.347 & 0.812 & 3.04 & 3.39 & 0.390 & 0.420 & 0.500 & 0.620 \\
\hline DIFEERENCE & 0.000 & 0.013 & 0.005 & 0.020 & -0.078 & -0.011 & -0.08 & -0.29 & -0.010 & -0.030 & -0.020 & -0.010 \\
\hline PERCENTACE & 0.0 & 2.4 & 0.7 & 4.3 & $\cdot-5.5$ & -1.4 & $-2: 5$ & -7.8 & -2.5 & -6.7 & -3.8 & -1.6 \\
\hline
\end{tabular}


Case 15: Efficiency Improvement in Residential Air Conditioning

Assumptions: Efficiency of residential air conditioners is improved by $30 \%$ ( 2.5 to 3.3 for central $\mathrm{a} / \mathrm{c}$ and 2.0 to 2.6 for room $\mathrm{a} / \mathrm{c}$ ).

Results: The results are very similar to those of the other three air conditioning sensitivity cases (Cases 12, 13, and 14). All of these cases result in about a $3 \%$ increase in annual load factor. 
Table F-17

RESULTS OF SENSITIVITY CASE 15

IMPROVED EFFICIENCY, RESIDENTIAL AIR CONDITIONING

$\left(10^{12} \mathrm{Btu} / \mathrm{Yr}\right)$

a. North Central Region

END USE

RESIDENTIAL

SPACE HEAT
WATER HEAT

WATER HEAT
AIR CONDITIONINO

COOKING

OTHER

COMNERCIAL
SPACE
AEAT

SPACE BEAT
AIR CONDITIONING

OTHER

INDUSTRIAL

TRAN SPORTATION

TOTAL

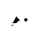

\section{1}

0.00

0.00

0.00
0.00

0.00

0.00
0.00

0.00
0.00

0.00

0.00

0.00

2
07.28
0.00
0.00
0.00
62.78
43.95
0.00
19.01

024.59
0.00

ECHNOLOGY

.51
7.51

.86

50.93
0.00

4
0.00

0.00
0.00

14.25

0.00
0.00

5
0.00

0.00

0.00

0.00
0.00

0.00
0.00

0.00

0.00

0.00
.0 .00

0.00

0.00

\begin{tabular}{ccrc}
7 & \multicolumn{1}{c}{8} & TOTAL & PERCENT \\
0.00 & 0.00 & 485.85 & 16.59 \\
0.00 & 0.00 & 137.51 & 4.70 \\
0.00 & 0.00 & 59.11 & 2.02 \\
0.00 & 0.00 & 50.93 & 1.74 \\
0.00 & 0.00 & 362.78 & 12.39 \\
& & 1096.18 & 37.43
\end{tabular}

\subsection{0 .00}

0.00

0.000 .00

0.00

0.00
0.00
0.00

$0.00 \quad 68.07$

68.07
120.93

120.93
619.01

2.32

$\begin{array}{ll}0.00 & 0.00\end{array}$

0.00

0.00

0.00

0.00

0.00

0.00

$0.00 \quad 1024.59$

21.14

27.59

34.98
0.00

$2928.79 \quad 100.00$

SUMHARY OUTPUTS - NORSH CENTRAL $2000 \quad 12 / 18 / 79$ IMPROVED EREICIENCY,RESIDENTIAL AIR CONDITIONINC

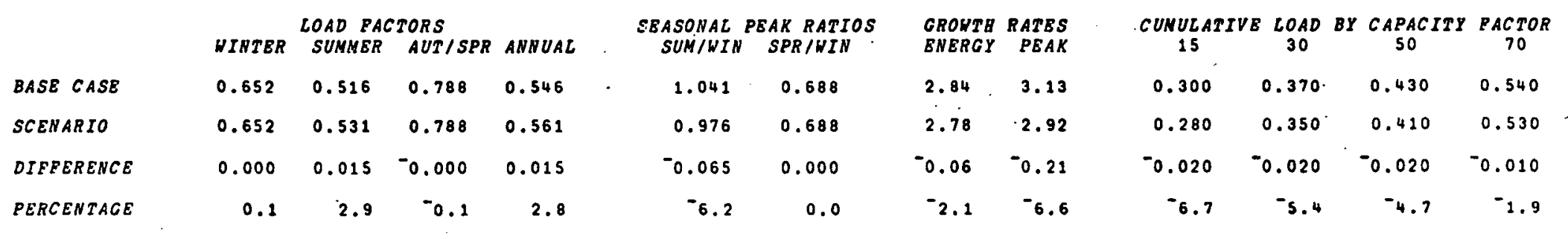


Table F-17, Continued

\section{b. South Central Region}

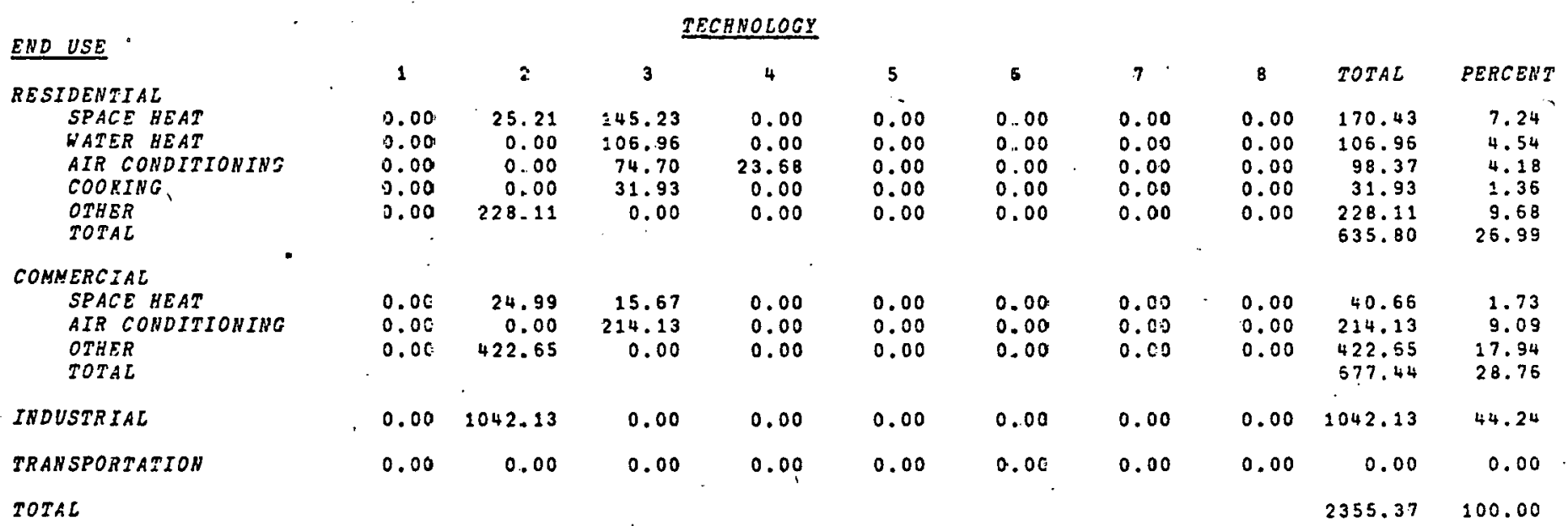

SUNMARY OUTFUTS -- SOUTH CENTRAL $200012,18.79$ IMPPOVEO EFEICIENCY, RESIDENTIAL AIR COHDITIONIKG

\begin{tabular}{|c|c|c|c|c|c|c|c|c|c|c|c|c|}
\hline & KINTER & $\begin{array}{l}\text { LOAD FAC } \\
\text { SUMMEP }\end{array}$ & $\begin{array}{l}\text { TORS } \\
\text { AUT ISPR }\end{array}$ & ANNUAL & $\begin{array}{l}\text { SEASONAL } \\
\text { SUM/WIK }\end{array}$ & $\begin{array}{c}\text { PEAK RATIOS } \\
\text { SPR /WIN }\end{array}$ & $\begin{array}{l}\text { GROWTH } \\
\text { ENERGY }\end{array}$ & $\begin{array}{l}\text { RATES } \\
\text { PEAKK }\end{array}$ & $\begin{array}{c}\text { CUMULATIV } \\
15\end{array}$ & $\begin{array}{c}E \text { LOAD } \\
30\end{array}$ & $\begin{array}{c}\text { EY CAPACITY } \\
50 .\end{array}$ & $\begin{array}{c}\text { PACTOR } \\
70\end{array}$ \\
\hline BASE CASE & 0.667 & 0.526 & 0.74 .3 & 0.471 & 1.425 & 0.823 & 3.12 & 3.68 & 0.400 & 0.450 & 0.520 & 0.630 \\
\hline SCENARIO & 0.667 & 0.535 & 0.747 & 0.493 & 1.331 & 0.810 & 3.00 & 3.22 & 0.390 & 0.410 & 0.500 & 0.620 \\
\hline DIFFERENCE & 0.000 & 0.009 & 0.003 & 0.022 & -0.094 & -0.014 & -0.12 & -0.25 & -0.010 & -0.040 & 0.020 & -0.010 \\
\hline PERCEU & 0.0 & 1.7 & 0.4 & 4.6 & -6.6 & -1.7 & -3.8 & -9.6 & -2.5 & -8.9 & -3.8 & -1.6 \\
\hline
\end{tabular}


Case 16: Electric Car -- Ten Percent Penetration

Assumptions: Ten percent of all vehicle miles driven in the year 2000. will be by electric car.

Results: Since virtually all charging is assumed to be off-peak, as indicated by the hypothetical electric car load shape of Appendix E, the electric car load is a good complement to the other loads. The three seasonal as well as the annual load factors increase. The growth rate of energy increases, but the growth in peak load does not. 
RESULTS OF SENSITIVITY CASE 16

ELECTRIC CAR - 10 PERCENT PENETRATION

$\left(10^{12} \mathrm{Btu} / \mathrm{Yr}\right)$

a. North Central Regicn

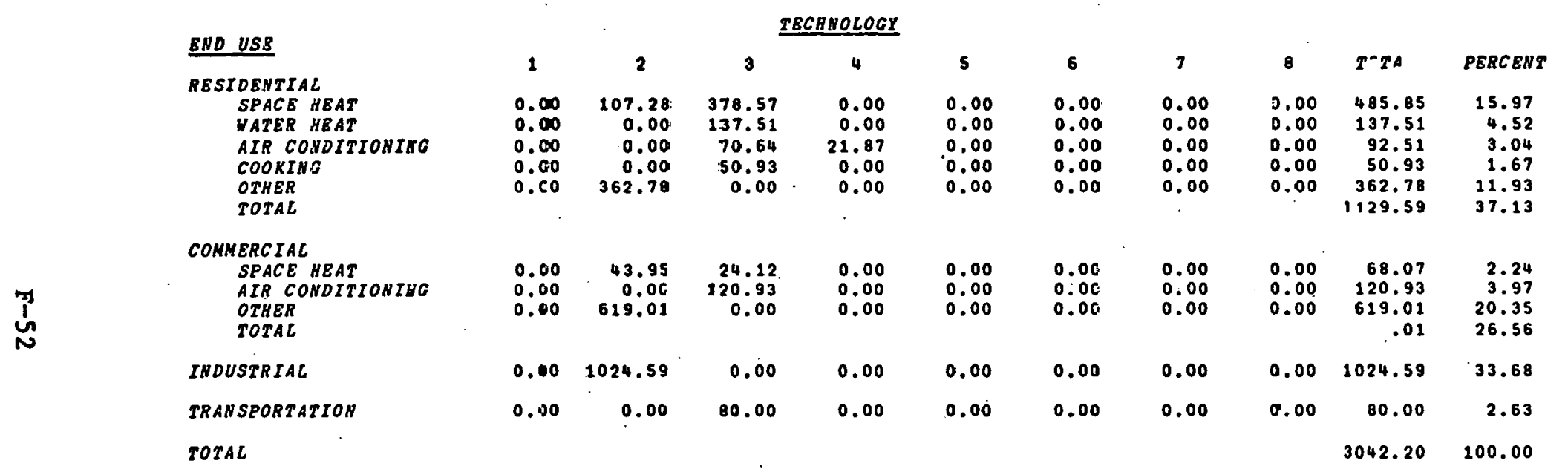

SUMNARY OUTPUTS -- MORTH CEMTRAL 2000

$1 / 8 / 80$

ELECTRIC SAR - 10 PERCENT PENBTRATION

\begin{tabular}{|c|c|c|c|c|c|c|c|c|c|c|c|c|}
\hline & HIUTER & $\begin{array}{c}\text { LOAD } P A C \\
\text { SUNMER }\end{array}$ & $\begin{array}{l}\text { CORS } \\
\text { AUT / SPR }\end{array}$ & ANWUAL & $\begin{array}{l}\text { SEASONAL } \\
\text { SUN /WIN }\end{array}$ & $\begin{array}{l}\text { PEAK RATIOS } \\
\text { SPR/WIN }\end{array}$ & $\begin{array}{l}\text { GRONTH } \\
\text { EKERGY }\end{array}$ & $\begin{array}{r}\text { RATES } \\
\text { PEAR }\end{array}$ & $\begin{array}{c}\text { CUNULATIVL } \\
15\end{array}$ & $\begin{array}{c}V E C O A D \\
30\end{array}$ & $\begin{array}{c}B Y \text { CAPACITY } \\
50\end{array}$ & $\begin{array}{c}Y \text { BACTOR } \\
70\end{array}$ \\
\hline BASE CASE & 0.652 & 0.516 & 0.788 & 0.546 & 1.041 & 0.688 & 2.84 & 3.13 & 0.300 & 0.370 & 0.430 & 0.540 \\
\hline SCENARTO & 0.656 & 0.528 & 0.800 & 0.558 & 1.030 & 0.687 & 2.97 & 3.15 & 0.290 & 0.360 & 0.420 & 0.520 \\
\hline DIFEERENCE & 0.005 & 0.012 & 0.011 & 0.013 & -0.011 & -0.000 & 0.14 & 0.03 & -0.010 & -0.010 & -0.010 & -0.020 \\
\hline PERCENTAGE & 0.7 & 2.3 & 1.5 & 2.3 & -1.1 & -0.0 & 4.8 & 0.8 & -3.3 & -2.7 & -2.3 & -3.7 \\
\hline
\end{tabular}


Table F-18, Continued

b. South Central Region

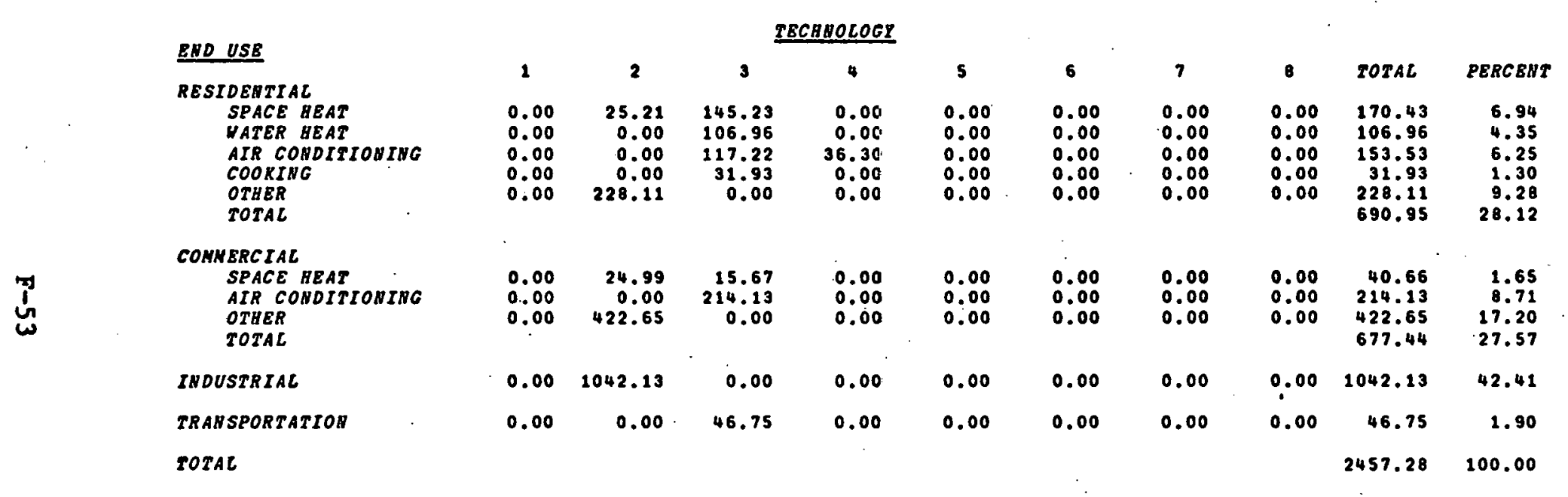

SUMNARY OUTPUTS -- SOUTR CENTRAL 2000 ELECTRIC CAR - 10 PERCENT PEUETRATION

$1 / 8 / 80$

LOAD EACTORS
WINTER SUMMER AUT/SPR ANIUAL

BASE CASE

SCENARTO

DIFEERENCE

PERCENTACE

$\begin{array}{llll}0.7 & 1.4 & 1.0 & 1.7\end{array}$

SEASONAL PEAK RATIOS SUN/PIN SPR/WIN

GROUTH RATES EUERGY PEAK

$1.425 \quad 0.823$

$1.410 \quad 0.821$

$\begin{array}{cc}-0.015 & -0.002\end{array}$

$-1.0 \quad-0.2$

$3.12 \quad 3.68$

$3.22 \quad 3.69$

$0.10 \quad 0.02$

3.20 .4

CUNULATIVE LOAD BY CAPACITY FACTOR

$15 \quad 30 \quad 50 \quad 50$

$\begin{array}{llll}0.400 & 0.450 & 0.520 & 0.630\end{array}$

$\begin{array}{llll}0.390 & 0.440 & 0.510 & 0.620\end{array}$

$\begin{array}{llll}-0.010 & -0.010 & -0.010 & -0.010\end{array}$ 
Case 17: Increased Industrial Self-Generation

Assumptions: The total industrial energy demand is assumed to be reduced by $20 \%$ from the base case.

Results: The annual load factor drops by about $2 \%$. The growth in energy and peak load also drops, but the drop in the peak load growth rate is less. The industrial share of the entire energy consumption also decreases from $35 \%$ in the base case to $30 \%$. Clearly, any loss of industrlal load tends to have a negative effect on the load factors. 
Table F-19

RESULTS OF SENSITIVITY CASE 17

INCREASED SELF-GENERATION

$\left(10^{12} \mathrm{Btu} / \mathrm{Yr}\right)$

a. North Central Region

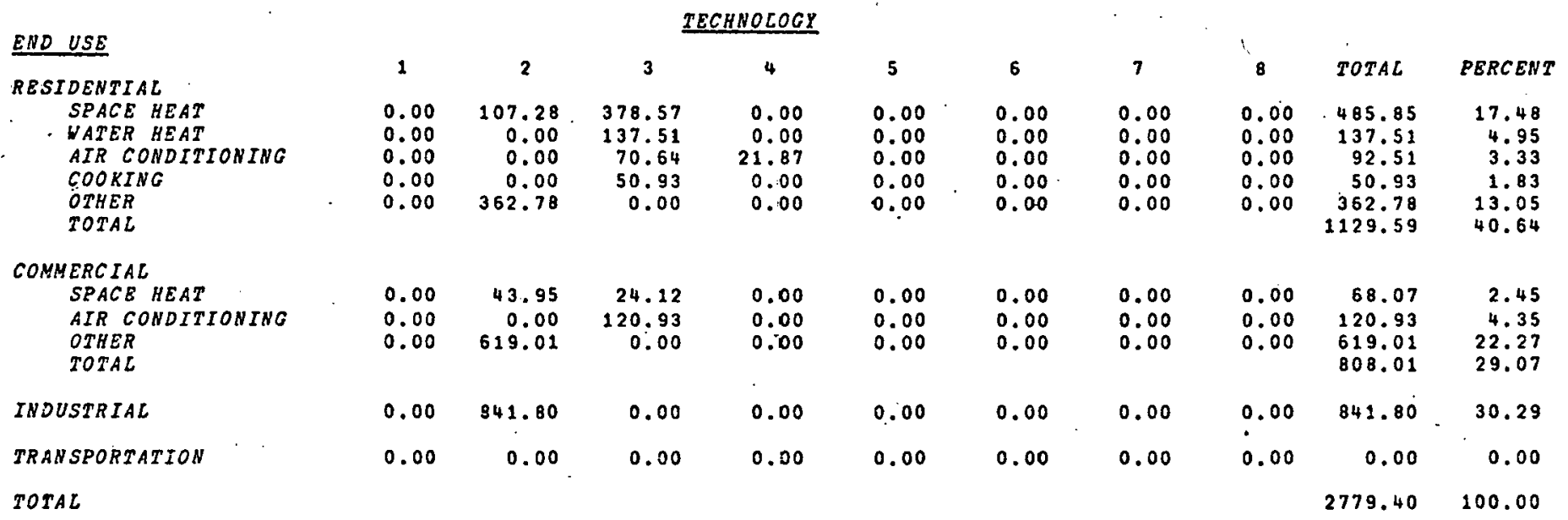

SUMMARY OUTPUTS -- DORTH CENGRAL $2000 \quad 12 / 18 / 79$ INCREASED COGENERATION

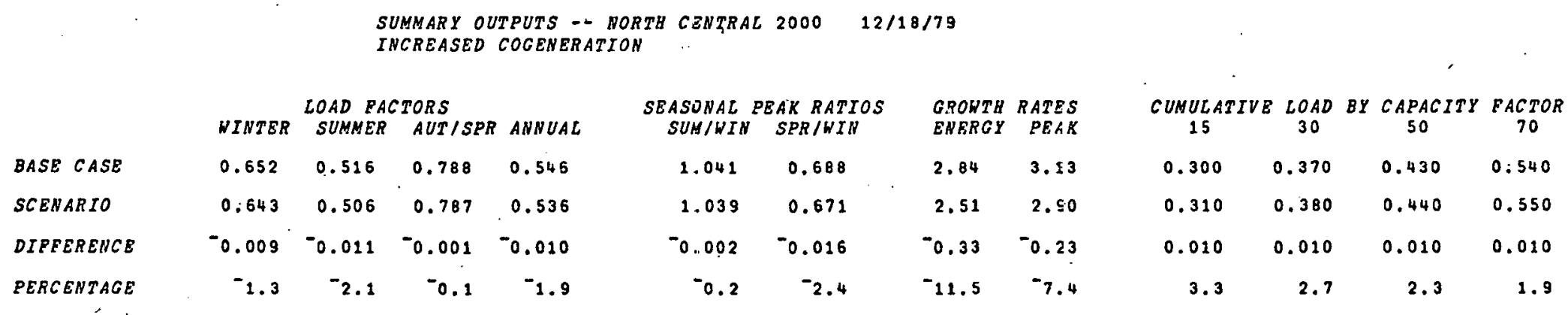




\section{b. South Central Region}

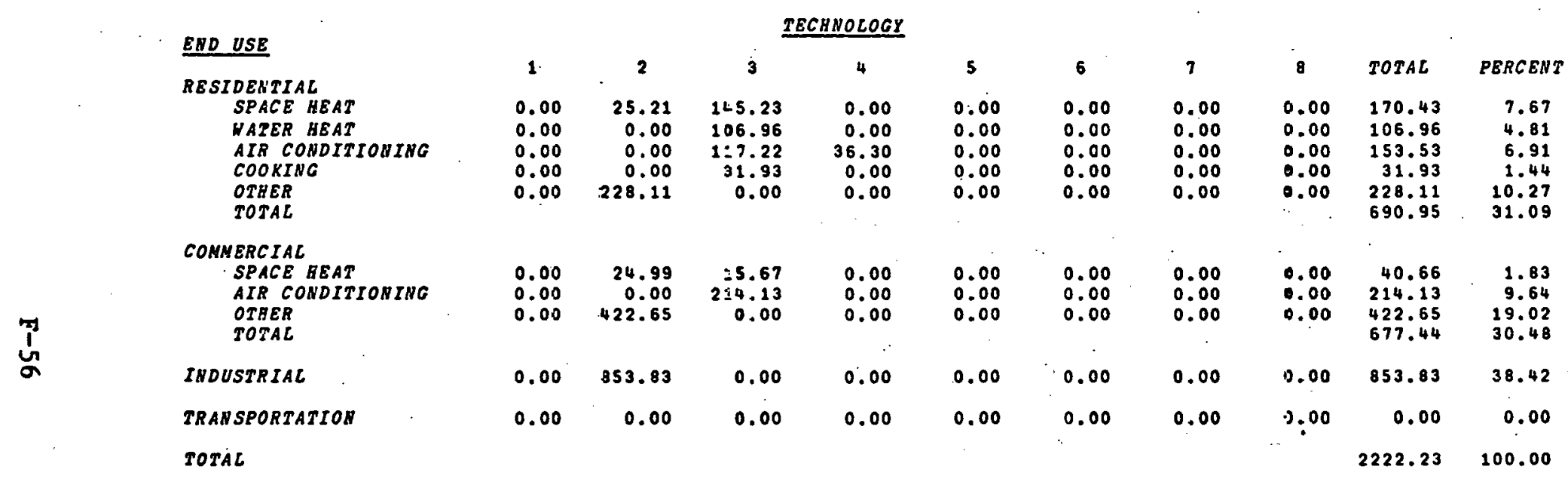

SUMAARY OUTPUTS -. SOUTE CBNTRAL $2000 \quad 12 / 18 / 79$ INCPEASED COGENERATION

\begin{tabular}{|c|c|c|c|c|}
\hline & WINTER & $\begin{array}{r}\text { LOAD FA } \\
\text { SUNAER }\end{array}$ & $\begin{array}{l}\text { TORS } \\
\text { JUT/SPR }\end{array}$ & ANGUAL \\
\hline BASE CASE & 0.667 & 0.526 & 0.743 & 0.471 \\
\hline SCENARIO & 0.655 & 0.514 & 0.739 & 0.456 \\
\hline DIPPERENCE & -0.012 & -0.012 & -0.005 & -0.015 \\
\hline PERCENTAGE & -1.8 & -2.3 & -0.6 & -3.1 \\
\hline
\end{tabular}

\begin{tabular}{cccc} 
SEASONAL PEAX RATIOS & \multicolumn{2}{c}{ GRCWTH RATES } \\
SUN/WIN & SPR/WIN & ENERGY & \multicolumn{1}{c}{ PEAK } \\
1.425 & 0.823 & 3.12 & 3.68 \\
1.446 & 0.807 & 2.70 & 3.42 \\
0.022 & -0.016 & -0.42 & -0.25 \\
1.5 & -2.0 & -13.4 & -6.9
\end{tabular}

CUMULATIVE LOAD BY CAPACITY FACTOR

\begin{tabular}{rrrr}
15 & 30 & 50 & \multicolumn{1}{c}{70} \\
0.400 & 0.450 & 0.520 & 0.630 \\
0.410 & 0.470 & 0.540 & 0.640 \\
0.010 & 0.020 & 0.020 & 0.010 \\
2.5 & 4.4 & 3.8 & 1.6
\end{tabular}


Case 18: High Solar Penetration In Residential Space and Water Heat

Assumptions: Solar space and water heating systems with nonstorable electric backup are installed in half of the new housing that otherwise (base case) would install electric resistance. In other words, installation shares are assumed to be $50 \%$ gas/o11, $25 \%$ resistance, $25 \%$ solar rather than $50 \%$ gas/oil and $50 \%$ resistance.

Results: The main effect of the introduction of solar heating is a reduction in energy requirement during the heating season which causes a $9 \%$ increase in the summer-to-winter peak rat1o. This leads to a $3.5 \%$ reduction in annual load factor in spite of a $3 \%$ increase in the winter load factor. 
RESULTS OF SENSITIVITY CASE 18

HIGH SOLAR PENETRATION, RESIDENTIAL SPACE AND WATER HEAT

$$
\left(10^{12} \mathrm{Btu} / \mathrm{Yr}\right)
$$

a. North Central Region

\section{END USE}

RESIDENTIAL

SPACE HEAT

AIR CONDITIONINC

COOKING

OTHER

TOTAL

COMMERCIAL

SPACE HEAT
AIR CONDITIONINO$$
\text { OTHER }
$$

in
INDUSTRIAL

TRANSPORTATION

TOTAL

\section{TECHNOLOGY}

\begin{tabular}{cr}
1 & \multicolumn{1}{c}{2} \\
0.00 & 107.28 \\
0.00 & 0.00 \\
0.00 & 0.00 \\
0.00 & 0.00 \\
0.00 & 362.78
\end{tabular}

$\begin{array}{rr}0.00 & 43.95 \\ 0.00 & 0.00 \\ 0.00 & 619.01\end{array}$

$$
0.00
$$

0

3
208.92
93.88
70.64
50.93
0.00

24.12
120.93
0.00
0.00
0.00

4
0.00
4.36
21.87
0.00
0.00

0.00
0.00
0.00
0.00
0.00

5
84.82
0.00
0.00
0.00
0.00

6
0.00
0.00
0.00
0.00
0.00

7
0.00
0.00
0.00
0.00
0.00

0.00
0.00
0.00
0.00
0.00

a

TOTAL

PERCENT

$0.00 \quad 401.03 \quad 14.13$

$0.00 \quad 98.25 \quad 3.46$

$0.00 \quad 92.51 \quad 3.26$

$\begin{array}{rrr}0.00 & 50.93 & 1.79 \\ 0.00 & 362.78 & 12.78\end{array}$

$1005.50 \quad 35.43$

\section{$\begin{array}{lll}c .00 & 68.07 & 2.40\end{array}$}

$0.00 \quad 120.93 \quad 4.26$

$\begin{array}{lll}0.00 \quad 619.01 & 21.81 \\ & 808.01 & 28.47\end{array}$

$\begin{array}{lllll}0.00 & 0.00 & 0.00 & 0.00 & 68.07 \\ 0.00 & 0.00 & 0.00 & 0.00 & 619.01 \\ & & & & 808.01\end{array}$

0.00

0.03

$0.00 \quad 1024.59$

36.10

$0.00 \quad 0.00$

0.00

0.00

0.00

$2838.11 \quad 100.00$

\section{SUMKARY OJTPUYS -- NORTH CENTRAL 2000 12/31/79}

HICH SOLA.Z PEMETRATION,RESIDENTIAL SPACE AND WATER HEAT

\begin{tabular}{lrrrrr} 
& \multicolumn{5}{c}{ LOAD FACTORS } \\
& NINTER & \multicolumn{1}{c}{ SUMAER } & \multicolumn{1}{l}{ AUT/SPR AHMUL } \\
BASE CASE & 0.652 & 0.516 & 0.788 & 0.548 \\
SCENARIO & 0.671 & 0.513 & 0.773 & 0.526 \\
DIFEERENCE & 0.020 & -0.003 & -0.015 & -0.019 \\
PERCENTACE & 3.0 & -0.6 & -1.9 & -3.5
\end{tabular}

\begin{tabular}{cccc}
$S E A S O N A L$ & PEAK RATIOS & \multicolumn{2}{c}{ GEONTH } \\
SUN $/ W T N$ & SPRININS & ENERCY & PEAK \\
1.041 & 0.688 & 2.84 & 3.13 \\
1.137 & 0.735 & 2.62 & 3.09 \\
0.097 & 0.047 & -0.22 & -0.04 \\
9.3 & 6.9 & -7.7 & -1.3
\end{tabular}

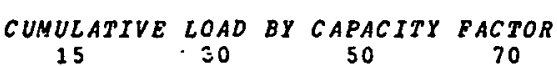

$\begin{array}{rrrr}0.300 & 0.370 & 0.430 & 0.540 \\ 0.330 & 0.390 & 0.450 & 0.560 \\ 0.030 & 0.020 & 0.020 & 0.020 \\ 10.0 & 5.4 & 4.7 & 3.7\end{array}$


b. South Central Region

END USE

RESIDENTIAL SPACE HEAT WATER $B E A T$ AIR CONDITIONINO COOKINC OTHER
TOTAL

COMMERCIAL

SPACE HEAT
AIR CONDITIONING
OTHER
TOTAL

INDUSTR IAL

TRAN SPORTATION

TOAAL

SUMMARY OUTPUTS -- SOUTH CENTRAL 2000 1/8/80 HIGH SOLAR PENETRATION.RESTDENTIAL SPACE HEAT

\begin{tabular}{lccccc} 
& \multicolumn{5}{c}{ LOAD FACTORS } \\
& WINTER & \multicolumn{1}{c}{ SUMMER } & AUT/SPR ANNUAL \\
BASE CASE & 0.667 & 0.526 & 0.743 & 0.471 \\
SCENARIO & 0.700 & 0.524 & 0.738 & 0.463 \\
DIPEERENCE & 0.032 & -0.003 & -0.006 & -0.008 \\
PERCENTACE & 4.8 & -0.5 & -0.8 & -1.8
\end{tabular}

\section{SEASONAL PEAK RATIOS SUM/WIN SPR/WIN}

$\begin{array}{rr}1.425 & 0.823 \\ 1.551 & 0.887 \\ 0.127 & 0.064 \\ 0.9 & 7.7\end{array}$

GROWTH RATES EUERGY PEAK

3.12

3.00

$-0.12$

$-4.0$

7
0.00
0.00
0.00
0.00
0.00

0.00
0.00
0.00
0.00
0.00

\section{8}

0.00

0.00
0.00

0.00

0.00
0.00

0.00

$0.00 \quad 40.66 \quad 1.73$

$0.00 \quad 214.13 \quad 9.10$

$\begin{array}{lll}0.00 \quad 422.65 & 17.96\end{array}$

$0.00 \quad 1042.13$

$0.00 \quad 0.00=0.00$

$2353.50 \quad 100.00$

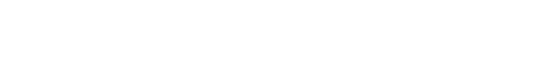


Case 19: High Replacements by Dual-fueled (Bivalent) Heat Pump Systems in the Residential Sector

Assumptions: Twenty percent of replacements of gas/o1l furnaces are dual-fueled heat pump systems in the residential sector.

Results: This case appears to have several positive impacts on the electric load. The summer-to-winter seasonal ratio is decreased by $3 \%$, and the fall/spring-to-winter ratio is increased by $2 \%$, Indicating that the seasons have become more even. The annual load factor increases by almost 5\%: Also, the growth rate in energy increases by $8 \%$ while the growth in peak remains constant. 
Table F-21

RESULTS OF SENSITIVITY CASE 19

DUAL FUELED RESIDENTIAL SPACE HEAT

$\left(10^{12} \mathrm{Btu} / \mathrm{Yr}\right)$

a. North Central Region

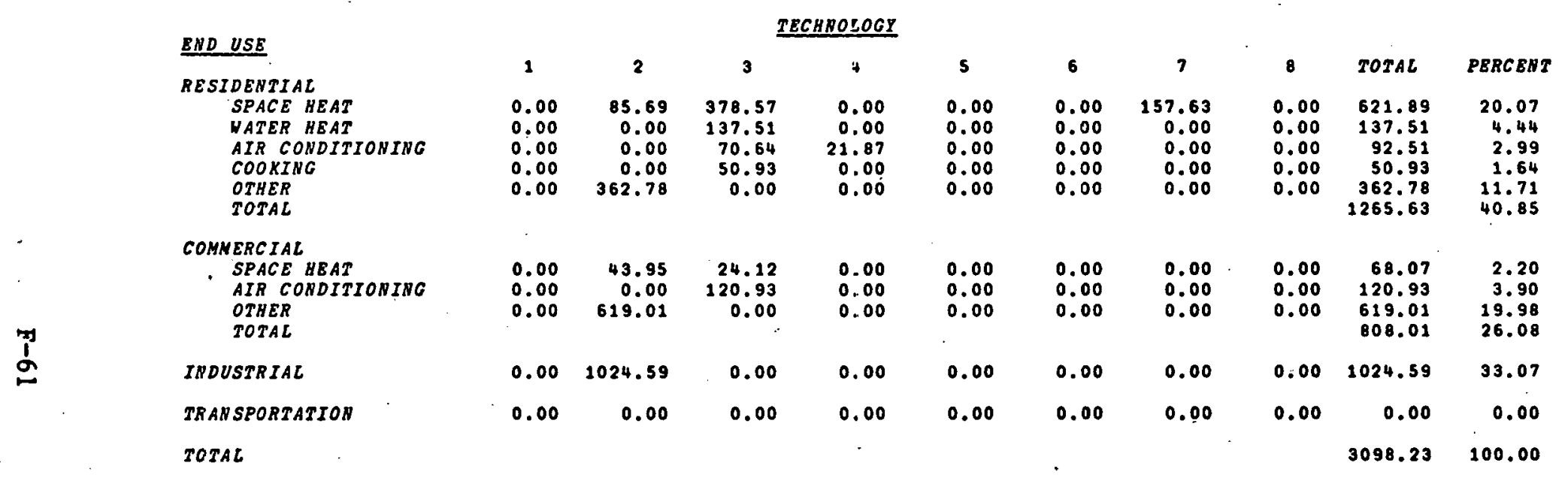

SUMNARY OUTPUTS - - NORTH CENTRAL 2000 12/31/79 DUAL PUELED RESIDENTIAL SPACE HEAT

\begin{tabular}{|c|c|c|c|c|c|c|c|c|c|c|c|c|}
\hline & WINTER & $\begin{array}{l}\text { LOAD FAC } \\
\text { SUMMER }\end{array}$ & $\begin{array}{l}\text { TORS } \\
\text { AUT / SPR }\end{array}$ & ANNUAL & $\begin{array}{l}\text { SEASONAL } \\
\text { SUM/WIB }\end{array}$ & $\begin{array}{c}\text { PEAK RATIOS } \\
\text { SPR/WIN }\end{array}$ & $\begin{array}{l}\text { GROWTH } \\
\text { BNERGY }\end{array}$ & $\begin{array}{r}\text { RATES } \\
\text { PEAK }\end{array}$ & $\underset{15}{\text { CUNULATIVL }}$ & $\begin{array}{c}E O A D \\
30\end{array}$ & $\begin{array}{c}B Y \text { CAPACITY } \\
50\end{array}$ & $\begin{array}{c}\text { PACTOR } \\
70\end{array}$ \\
\hline BASE CASE & 0.652 & 0.516 & 0.788 & 0.546 & 1.041 & 0.688 & 2.84 & 3.13 & 0.300 & 0.370 & 0.430 & 0.540 \\
\hline SCENARIO & 0.665 & 0.516 & 0.804 & 0.571 & 1.006 & 0.702 & 3.07 & 3.33 & 0.280 & 0.330 & 0.400 & 0.510 \\
\hline DIFRERENCE & 0.013 & 0.000 & 0.016 & 0.026 & -0.035 & 0.015 & 0.23 & 0.00 &.-0.020 & -0.040 & -0.030 & -0.030 \\
\hline PERCENTACE & 2.0 & 0.0 & 2.0 & 4.7 & -3.3 & 2.1 & 8.1 & 0.0 & -6.7 & -10.8 & -7.0 & -5.6 \\
\hline
\end{tabular}


Table F-21, Continued

b. South Central Region

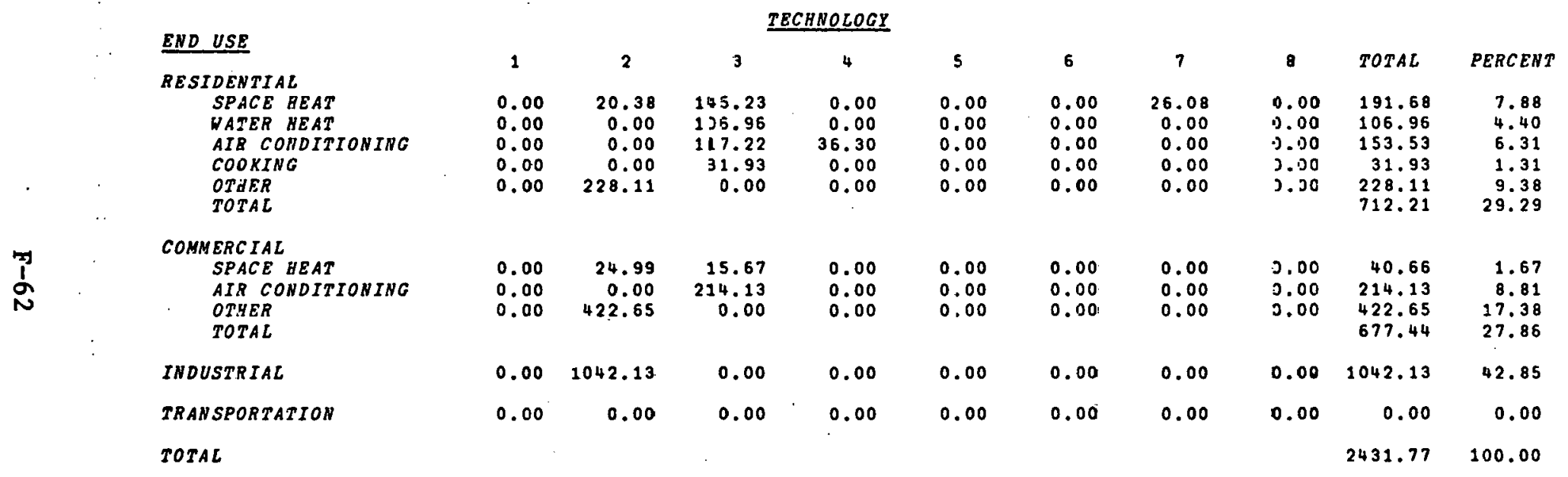

SUMYARY OCTPUTS -- SOUTH CENTRAL 2000 1/8/80 DUAZ PUELED RESIDENTIAL SPACE HEAT LOAD BACTORS
WINTER SUMMER AUT/SPP ANTOAL

BASE CASE

SCENARTO

DIPPERENCE

PERCEUTAGE $\begin{array}{lllll}0.667 & 0.525 & 0.743 & 0.471\end{array}$

$\begin{array}{lllll}0.672 & 0.525 & 0.748 & 0.176\end{array}$

$\begin{array}{llll}0.005 & 0.000 & 0.005 & 0.004\end{array}$

$\begin{array}{llll}0.8 & 0.0 & 0.6 & 1.0\end{array}$

SEASONAL PEAK RATIOS SUN/WIN SPR/WIN

1.4250 .823

$1.420 \quad 0.830$

$-0.005$

0.007

$-0.3$

0.8
GROWTH RATRS EN SRCY PRAK

$3.12 \quad 3.68$

$3.16 \quad 3.68$

0.050 .00

1.50 .0 $\begin{array}{cccc}\text { CUMULATIVE LOAD } & \text { BY } & \text { CAPACITY PACTOR } \\ 15 & 30 & 50 & 70\end{array}$

$\begin{array}{cccc}15 & 30 & 50 & 70 \\ 0.400 & 0.450 & 0.520 & 0.630 \\ 0.400 & 0.440 & 0.510 & 0.630 \\ 0.000 & -0.010 & -0.010 & 0.000 \\ 0.0 & -2.2 & -1.9 & 0.0\end{array}$


Case 20: Brookhaven Growth Rates to 2000

Assumptions: North Central sector growth rates calculated from Reference [4] projections:

\begin{tabular}{|c|c|c|c|}
\hline & $\begin{array}{l}1972- \\
1980 \\
\end{array}$ & $\begin{array}{l}1981- \\
1985 \\
\end{array}$ & $\begin{array}{l}1986- \\
2000 \\
\end{array}$ \\
\hline Residential & 1.8 & 1.4 & 1.0 \\
\hline Commercial & 2.6 & 1.3 & 1.2 \\
\hline Industrial & 3.5 & 4.2 & 3.9 \\
\hline
\end{tabular}

South Central Brookhaven growth rates are:

$\begin{array}{llll} & 1972- & 1981- & 1986- \\ & \frac{1980}{1.4} & \frac{1985}{2.0} & \frac{2000}{1.3} \\ \text { Residential } & 1.4 & 2.0 & 1.3 \\ \text { Commercial } & 2.6 & 1.6 & 1.5 \\ \text { Industrial } & 4.4 & 4.8 & 4.4 .\end{array}$

The year Intervals were made to correspond with those in Brookhaven.

Results: The annual load factor increased by over $10 \%$, the largest increase of all the sensitivity cases. The growth rate of energy also increased by a large amount (22\%), while the growth rate of peak demand increased by only $4 \%$. The total share of industrial energy consumption increased from $35 \%$ to $48 \%$. These results follow clearly from the very high projected growth in industrial and commercial load compared with residential. 
RESULTS OF SENSITIVITY CASE 20

BROOKHAVEN GROWTH RATES

$$
\left(10^{12} \mathrm{Btu} / \mathrm{Yr}\right) \text {. }
$$

a. North Central Region

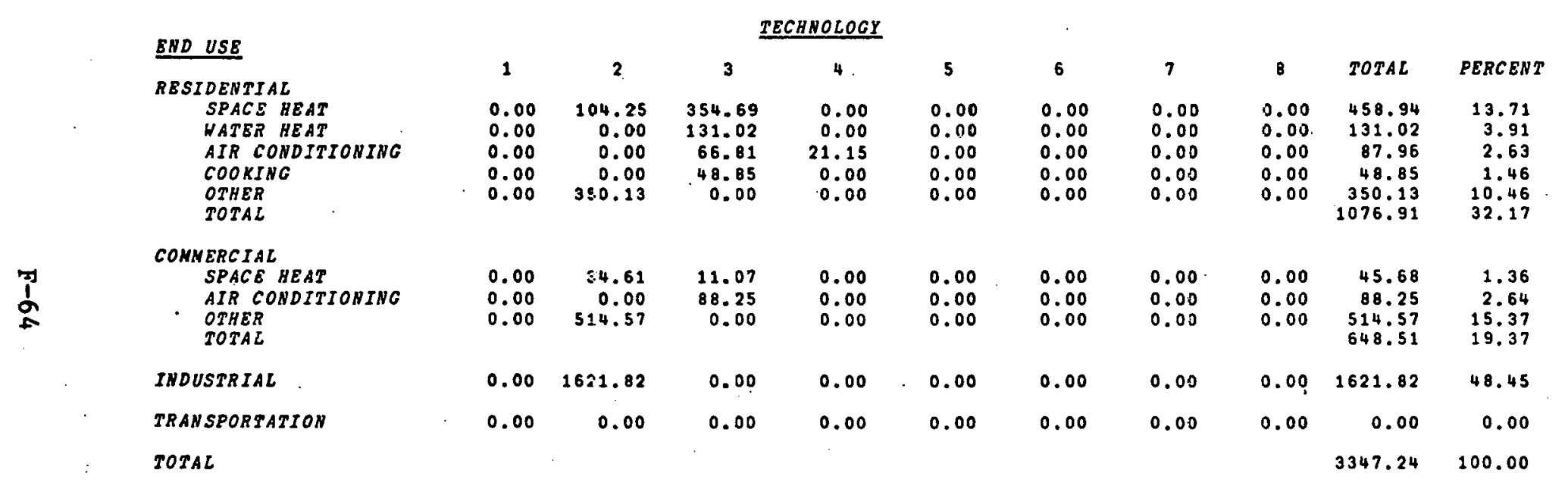

SUMMAPY OUTPUTS -- NORTH CBNTRAL 2000 12/18/79 BROOKEAVEN GROUTY RATES

\begin{tabular}{|c|c|c|c|c|c|c|c|c|c|c|c|c|}
\hline & WINTER & $\begin{array}{l}\text { LOAD } P A C \\
\text { SUHMER }\end{array}$ & $\begin{array}{l}\text { TORS } \\
\text { AUS/SPR }\end{array}$ & AINUAC & $\begin{array}{l}\text { SBASONAL } \\
\text { SUM/WIN }\end{array}$ & $\begin{array}{c}P E A K \text { RATIOS } \\
\text { SPR/WIN }\end{array}$ & $\begin{array}{l}\text { GROWTH } \\
\text { SNERGY }\end{array}$ & $\begin{array}{l}\text { RATBS } \\
\text { PEAK }\end{array}$ & $\underset{15}{\text { CUNULATIVE }}$ & $\begin{array}{c}E \text { LOAD } \\
30\end{array}$ & $\begin{array}{c}B Y \text { CAPACITY } \\
50\end{array}$ & $\begin{array}{c}Y \text { PACTOR } \\
70\end{array}$ \\
\hline BASE CASE & 0.652 & 0.516 & 0.988 & 0.546 & 1.041 & 0.688 & 2.84 & 3.13 & 0.300 & 0.370 & 0.430 & 0.540 \\
\hline SCENARIO & 0.677 & 0.572 & 0.790 & 0.602 & 0.993 & 0.739 & 3.47 & 3.25 & 0.250 & 0.300 & 0.370 & 0.4 .90 \\
\hline DIFFERENCE & 0.026 & 0.055 & 0.002 & 0.056 & -0.048 & 0.051 & 0.63 & 0.13 & -0.050 & -0.070 & -0.060 & -0.050 \\
\hline PERCENTAGE & 3.9 & 10.7 & 0.2 & 10.3 & -4.6 & 7.4 & 22.2 & 4.0 & -16.7 & -18.9 & -14.0 & -9.3 \\
\hline
\end{tabular}


Table F-22, Continued

b. South Central Region

\begin{tabular}{|c|c|c|c|c|c|c|c|c|c|c|c|}
\hline & \multicolumn{11}{|c|}{ TECHNOLGCY } \\
\hline & 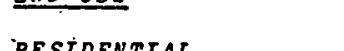 & 1. & 2 & 3 & 4 & 5 & 6 & 7 & 8 & TOTAL & PERCENT \\
\hline & $\begin{array}{l}\text { RESIEETTAL } \\
\text { SPACE HEAT } \\
\text { HATER HEAT } \\
\text { ATR CONDITIONING } \\
\text { COOKING } \\
\text { OOHER } \\
\text { TOTAL }\end{array}$ & $\begin{array}{l}0.00 \\
0.00 \\
0.00 \\
0.00 \\
0.00\end{array}$ & $\begin{array}{r}25.14 \\
0.00 \\
0.00 \\
0.00 \\
222.73\end{array}$ & $\begin{array}{r}133.86 \\
101.43 \\
109.66 \\
30.58 \\
0.00\end{array}$ & $\begin{array}{r}0.00 \\
0.00 \\
35.79 \\
0.00 \\
0.00\end{array}$ & $\begin{array}{l}0.00 \\
0.00 \\
0.00 \\
0.00 \\
0.00\end{array}$ & $\begin{array}{l}0.00 \\
0.00 \\
0.00 \\
0.00 \\
0.00\end{array}$ & $\begin{array}{l}0.00 \\
0.00 \\
0.00 \\
0.00 \\
0.00\end{array}$ & $\begin{array}{l}0.00 \\
0.00 \\
0.00 \\
0.00 \\
0.00\end{array}$ & $\begin{array}{l}159.00 \\
101.43 \\
145.45 \\
30.58 \\
222.73 \\
659.19\end{array}$ & $\begin{array}{r}5.45 \\
3.48 \\
4.98 \\
1.05 \\
7.63 \\
22.59\end{array}$ \\
\hline & $\begin{array}{l}\text { COMMERCTAL } \\
\text { SPACE \&EAT } \\
\text { AIR CONDITIONING } \\
\text { OORER } \\
\text { TOTAL }\end{array}$ & $\begin{array}{l}0.00 \\
0.00 \\
0.00\end{array}$ & $\begin{array}{r}18.45 \\
0.00 \\
332.65\end{array}$ & $\begin{array}{r}7.01 \\
145.11 \\
0.00\end{array}$ & $\begin{array}{l}0.00 \\
0.00 \\
0.00\end{array}$ & $\begin{array}{l}0.00 \\
0.00 \\
0.00\end{array}$ & $\begin{array}{l}0.00 \\
0.00 \\
0.00\end{array}$ & $\begin{array}{l}0.00 \\
0.00 \\
0.00\end{array}$ & $\begin{array}{l}0.00 \\
0.00 \\
0.00\end{array}$ & $\begin{array}{r}25.46 \\
145.11 \\
332.65 \\
.503 .22\end{array}$ & $\begin{array}{r}0.87 \\
4.97 \\
11.40 \\
17.24\end{array}$ \\
\hline & INDUSTRIALL & 0.00 & 1756.17 & 0.00 & 0.00 & 0.00 & 0.00 & 0.00 & 0.00 & 1756.17 & 60.17 \\
\hline & TRANSPORTATIOA & 0.00 & 0.00 & 0.00 & 0.00 & 0.00 & 0.00 & 0.00 & 0.00 & 0.00 & 0.00 \\
\hline & TOTAL & & & & & & & & & 2918.58 & 100.00 \\
\hline
\end{tabular}

SUMNARY OUTYUTS -- SOUTA CENTRAL 2000 .12/18/79 BROOKHAVEN GROWTH RATES LOAD RACTORS
WINTER SUMERER AUT/SPR ANNUAL

BASB CASE

SCEVARIO

DIFEERENCE

$\begin{array}{lllll}0.667 & 0.526 & 0.743 & 0.471\end{array}$

PERCENTAGE

$\begin{array}{llll}0.708 & 0.590 & 0.756 & 0.552\end{array}$

$\begin{array}{llll}0.041 & 0.063 & 0.012 & 0.081\end{array}$

6.1

$12: 0 \quad 1.6 \quad 17.3$

SEASONAL PBAK RATIOS SUM/WIN SPR IWIN

1.4250 .823

1.272

0.879

$-0.153$

0.056

$-10.7$

6.8
GROHTH RATES ENERGY PEAX

3.12 3:68

4.1. 3.84

$0.99 \quad 0.17$

$31.8 \quad 4.6$ \begin{tabular}{cccc} 
CUNULATIVE & LOAD & BY & CAPACITY PACTOR \\
\hdashline 15 & 30 & 50 & 70
\end{tabular}

$0.400 \quad 0.450 \quad 0.520 \quad 0.630$

$0.310 \quad 0.340 \therefore 0.450 \quad 0.550$

$\begin{array}{lllll}-0.090 & -0.110 & -0.070 & -0.080\end{array}$

$-22.5 .-24.4 \quad-13.5 \quad-12.7$ 
Case 21: Brookhaven Growth Rates to 1980

Assumptions: 1972-1980 sector growth rates from Reference [4] were used to estimate 1980 energy allocations.

Results: There is almost no change in load factors. Energy and peak load growth rates appear to increase, but this is due to higher starting levels in 1980 rather than differences between 1980 and 2000 . 


\section{Table F-23}

RESULTS OF SENSITIVITY CASE 21

BROOKHAVEN GROWTH RATES TO 1980

$$
\left(1 \mathrm{C}^{12} \mathrm{Btu} / \mathrm{Yr}\right)
$$

a. North Central Region

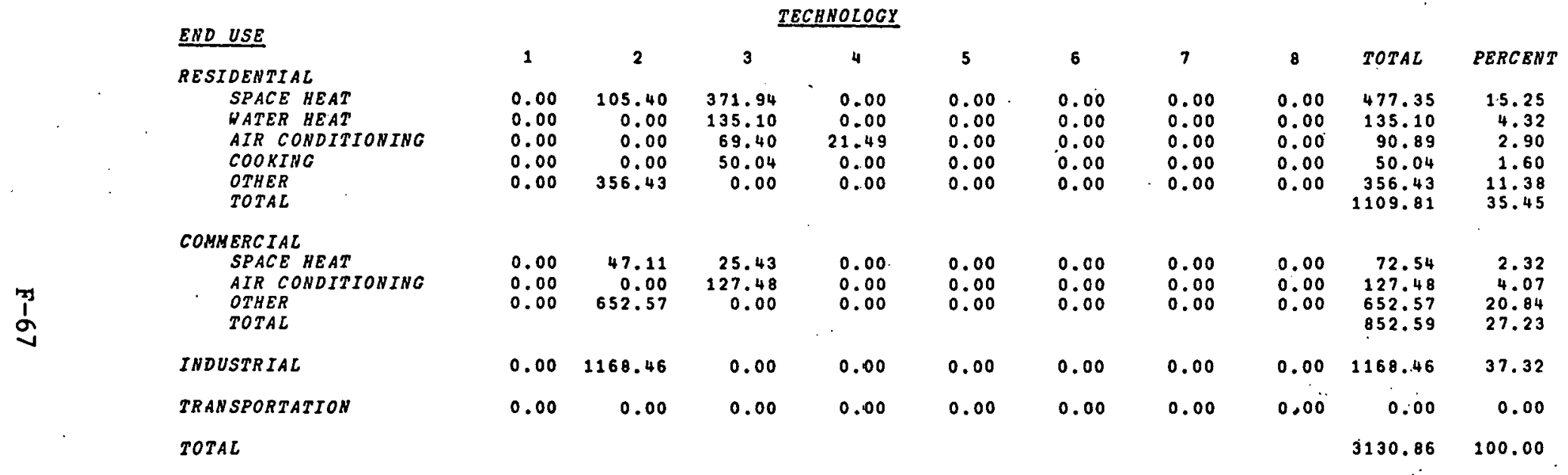

SUMMARY OUTPUTS -- NORTH CENTRAL $200012 / 18 / 79$ BROOKHAVEN GROWTH RATES TO 1980
LOAD FACTORS

WINTER SUMNER AUT/SPR ANNUAL

BASE CASE

SCENARTO

DIREERENCE

PERCENTAGE

$\begin{array}{rrrr}0.652 & 0.516 & 0.788 & 0.546 \\ 0.662 & 0.520 & 0.788 & 0.546 \\ 0.010 & 0.004 & -0.000 & 0.001 \\ 1.5 & 0.8 & -0.0 & 0.1\end{array}$
SUY/WIH SPR/WIN

1.041

1.06 .6

0.025

2.4
SEASTNAL PEAK RATIOS
0.688

0.706

0.019

2.7
GROWTH RATES ENERGY PEAK

$2.84 \quad 3.13$ $\begin{array}{cccc}\text { CUNULATIVE } & \text { LOAD BY CAPACITY EACTOR } \\ 15 & 30 & 50 & 70\end{array}$

$\begin{array}{llll}0.300 & 0.370 & 0.430 & 0.540\end{array}$

$0.310 \quad 0.370$

$0.010 \quad 0.000$

$0.420 \quad 0.540$

0.000
0.290 .88

3.3 
Table F-23, Continued

b. South Central Region

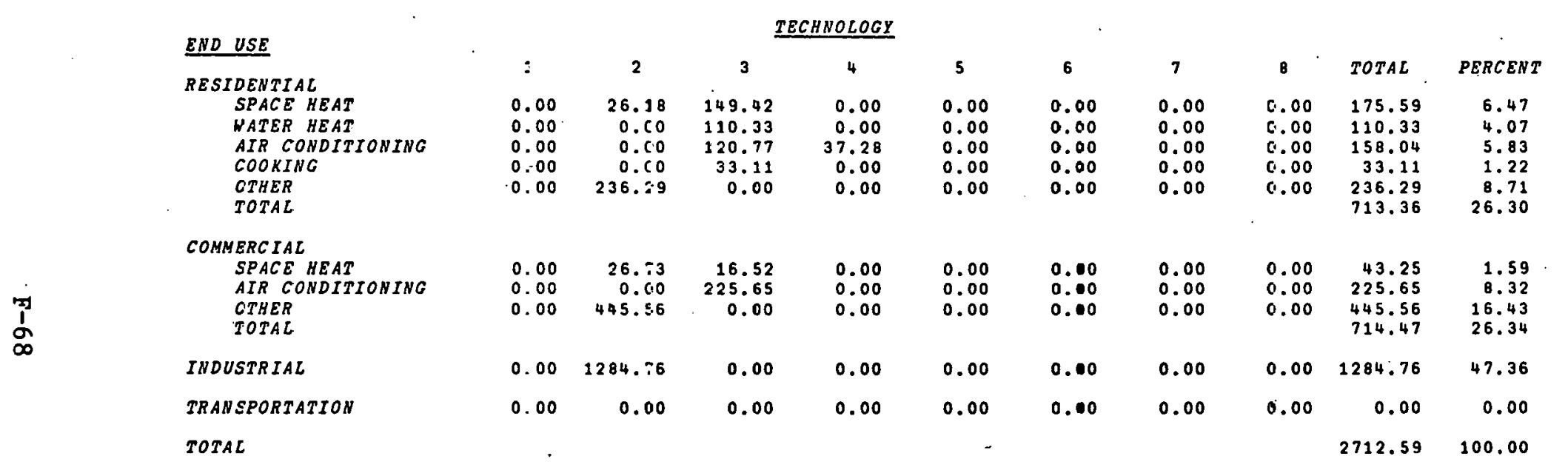

SUHNARY QUTPETS -. SOUTH CENTRAL $2000 \quad 12 / 13 / 79$ BROOKHAVEN GBOWTH RATES TO 1980

\begin{tabular}{lccccc} 
& \multicolumn{5}{c}{$\angle O A D$ PACTORS } \\
& WINTER & \multicolumn{2}{l}{ SUMDER } & AUT/SPR & ABNUAL \\
BASE CASE & & 0.667 & 0.596 & 0.743 & 0.471 \\
SCENARIO & & 0.680 & 0.536 & 0.750 & 0.485 \\
DIFPERENCE & 0.013 & 0.010 & 0.006 & 0.014 \\
PERCENTACE & 1.9 & 1.9 & 0.8 & 2.9
\end{tabular}

SEASONAL PEAK RATIOS SUM/WIN SPR/WIN

GRONTH RATES ENSRGY PEAR

1.425

0.823

1.4120 .840

$-0.013$

0.017

$-0.9$

3.123 .68

CUMULATIVE LOAD BY CAPACITY FACTOR 
Case 22: Electric Car -- Fifty Percent Penetration

Assumptions: Installation share and replacement shares for automobiles are set at $50 \%$ gasoline and $50 \%$ electric.

Results: The results are in the same direction but much more extensive than Case 16, which has $10 \%$ penetration of electric cars. In this case, the annual load factor increases by over $9 \%$ 
Table F-24

RESULTS OF SENSITIVITY CASE 22

ELECTRIC CAR - 50 PERCENT PENETRATION

$\left(10^{12} \mathrm{Btu} / \mathrm{Yr}\right)$

a. North Central Region

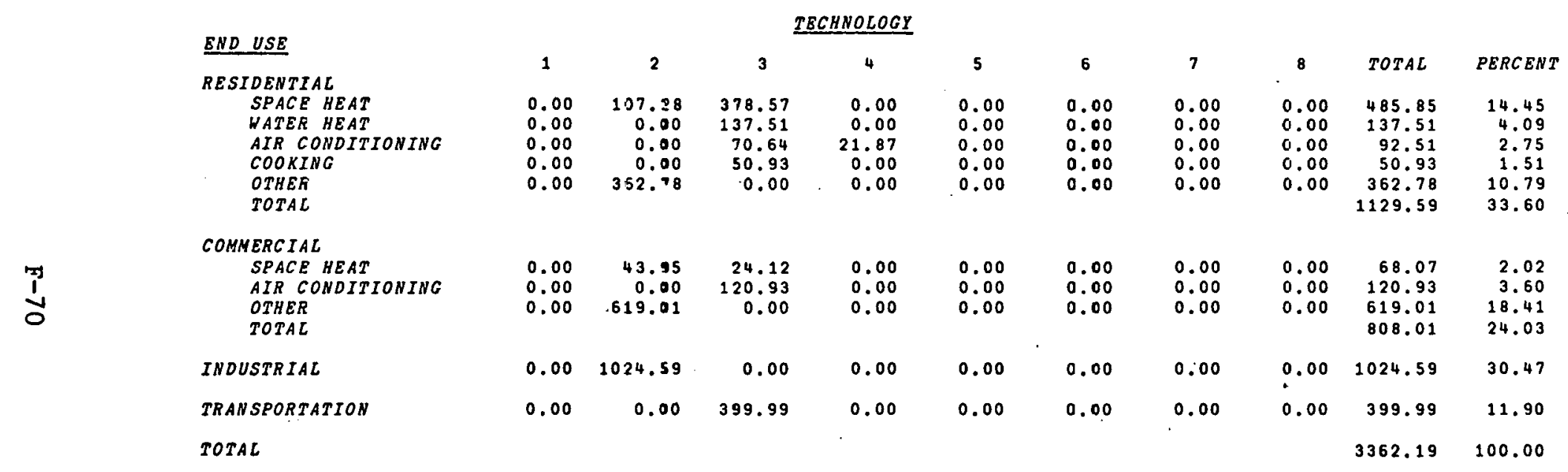

SUMMARY OUTPETS -- NORTH CENTRAL 2000 ELECTRIC CAR - 50 PERCENT PENETRATION

$1 / 8 / 80$ LOAD PACTORS
WINTER SUMMER AUT/SPR AYIUAL

BASE CASE SCENARTO

DIPFERENCE $\begin{array}{llll}0.652 & 0.516 & 0.788 & 0.546\end{array}$

$\begin{array}{lllll}0.676 & 0.575 & 0.834 & 0.597\end{array}$

PERCENTAGE

$\begin{array}{llll}0.024 & 0.058 & 0.046 & 0.051\end{array}$

$\begin{array}{llll}3.7 & 11.3 & 5.8 & 9.4\end{array}$

SEASONAL PEAK RATIOS
SUM/WIN SPR/WIN

1.0410 .688

$0.988 \quad 0.688$

$\begin{array}{cc}-0.053 & -0.000\end{array}$

$-5.1 \quad-0.0$
GEOWTH RATES ENERGY PEAK

$2.84 \quad 3.13$

3.493 .31

$0.65 \quad 0.19$

23.06 .0 $\begin{array}{cccc}\text { CUMULATIVE } & \text { LOAD BY CAPACITY FACTOR } \\ 15 . & 30 & 50 & 70\end{array}$

$\begin{array}{llll}0.300 & 0.370 & 0.430 & 0.540\end{array}$

$\begin{array}{lllll}0.280 & 0.330 & 0.390 & 0.470\end{array}$

$\begin{array}{lllll}-0.020 & -0.040 & -0.040 & -0.070\end{array}$

$\begin{array}{llll}-6.7 & -10.0 & -9.3 & -13.0\end{array}$ 
Table F-24, Continued

b. South Central Region

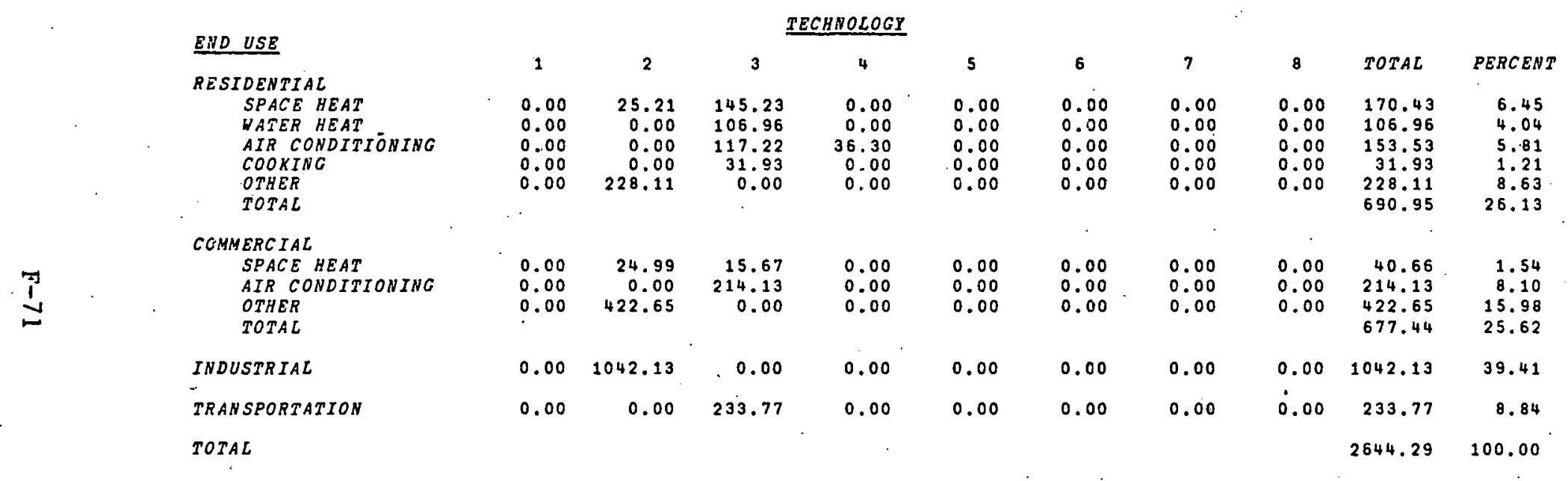

SUMMARY OUTPUTS -- SOUTH CENTRAL 2000 1/8/80 ELECTRIC CAR - 50 PERCENT PENETRATION

\begin{tabular}{|c|c|c|c|c|c|c|c|c|}
\hline . & WINTER & $\begin{array}{c}\text { LOAD FAC } \\
\text { SUMYER }\end{array}$ & $\begin{array}{l}\text { TORS } \\
\text { AUT / SPR }\end{array}$ & ANNUAL & $\begin{array}{l}\text { SEASONAL } \\
\text { SUH/WIN }\end{array}$ & $\begin{array}{c}\text { PEAK RATIOS } \\
\text { SPR /WIN }\end{array}$ & $\begin{array}{l}\text { GROWTH } \\
\text { ENERGY }\end{array}$ & $\begin{array}{l}\text { RATES } \\
\text { PEAK }\end{array}$ \\
\hline BASE CASE & 0.667 & 0.526 & 0.743 & 0.471 & 1.425 & 0.823 & 3.12 & 3.68 \\
\hline SCENARIO & 0.685 & 0.562 & 0.781 & 0.509 & 1.355 & $0.814^{\circ}$ & 3.60 & 3.75 \\
\hline DIFEERENCE & 0.018 & 0.036 & 0.038 & 0.038 & -0.070 & -0.010 & 0.48 & $0.0 \mathrm{~B}$ \\
\hline PERCENTAGE & 2.7 & 6.8 & 5.1 & 8.0 & -4.9 & -1.2 & 15.3 & 2.2 \\
\hline
\end{tabular}

CUMULATIVE LOAD BY CAPACITY EACTOR

$\begin{array}{cccc}15 & 30 & 50 & 70 \\ 0.400 & 0.450 & 0.520 & 0.630 \\ 0.390 & 0.440 & 0.490 & 0.570 \\ -0.010 & -0.010 & -0.030 & -0.060 \\ -2.5 & -2.2 & -5.8 & -9.5\end{array}$


Case 23: High Solar Penetration in Residential Space and Water Heat Combined with 20\% Electric Resistance Replacements

Assumptions: Same as Case 18 except with 20\% replacements of gas/oil

furnaces by electric resistance as in Case 9.

Results: Compared to the base case, this sensitivity case causes a reduction in annual load factor of $3.5 \%$. However, compared to Case 9, on which it is based, this case shows a $6 \%$ increase in annual load factor. The growths in energy and peak demand are also reduced. 
Table F-25

RESULTS OF SENSITIVITY CASE 23

25 PERCENT SOLAR PENETRATION WITH 20 PERCENT RES SPACE HEAT REPLACEMENTS

$$
\left(10^{12} \mathrm{Btu} / \mathrm{Yr}\right)
$$

a. North Central Region

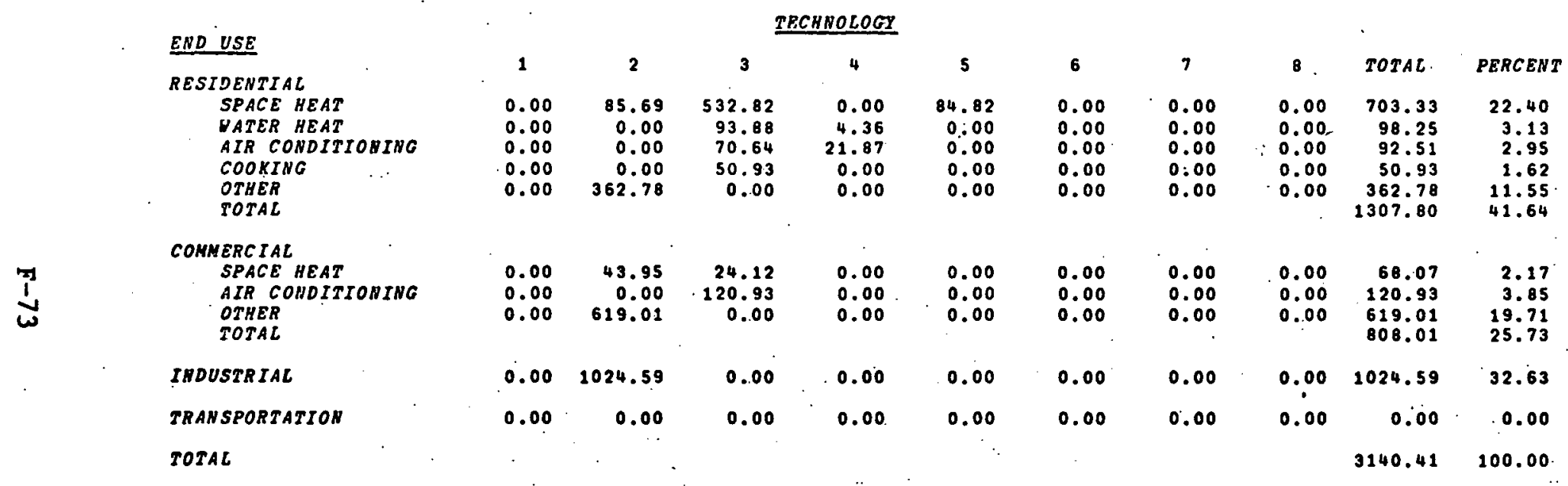

SUNMARY OUTPUTS -- MORTH CENTRAL 2000 1/13/80

25 PERCENT SOLAR PENETRATION WITH 20 PERCENT RES SPACB GBAT RBPLACBNRUTS

\begin{tabular}{|c|c|c|c|c|c|c|c|c|c|c|c|c|c|}
\hline . & UIRTER & $\begin{array}{l}\text { LOAD BAC } \\
\text { SUMNER }\end{array}$ & $\begin{array}{l}\text { TORS } \\
\text { AUT / SPR }\end{array}$ & ANBUAC: & $\begin{array}{c}\text { SEASOHAL } \\
\quad \text { SUN/WIE }\end{array}$ & $\begin{array}{l}\text { PEAK RATTOS } \\
\text { SPR/WIN. }\end{array}$ & $\begin{array}{l}\text { GROUTH } \\
\text { EARAGY }\end{array}$ & $\begin{array}{l}\text { RAFES } \\
\text { PEAK }\end{array}$ & $\begin{array}{l}\text { CUNULATIVE } \\
15\end{array}$ & $\begin{array}{l}\text { COAD } \\
=30\end{array}$ & $B Y$ & $\underset{50}{\text { CAPACITY }}$ & $\begin{array}{c}\text { PACTOR } \\
70\end{array}$ \\
\hline BASE CASE & 0.652 & 0.516 & 0.788 & 0.546 & 1.04 .1 & 0.688 & 2.84 & 3.13 & 0.300 & 0.370 & & $0.430^{\circ}$ & 0.540 \\
\hline SCBEARIO & 0.619 & 0.513 & 0.793 & 0.507 & 0.870 & 0.617 . & 3.14 & $3: 8.1$ & $0.360^{\circ}$ & 0.410 & & 0.470 & 0.570 \\
\hline DIFPERENCE & 0.033 & -0.004 & 0.005 & -0.039 & -0.171 & -0.070 & 0.30 & .0 .68 & 0.060 & 0.040 & & 0.040 & 0.030 \\
\hline PERCENTAGE & -5.0 & -0.8 & 0.7 & -7.1 & -16.4 & -10.2 & 10.6 & $21: 7$ & 20.0 & 10.8 & & 9.3 & 5.6 \\
\hline
\end{tabular}


b. South Central Region

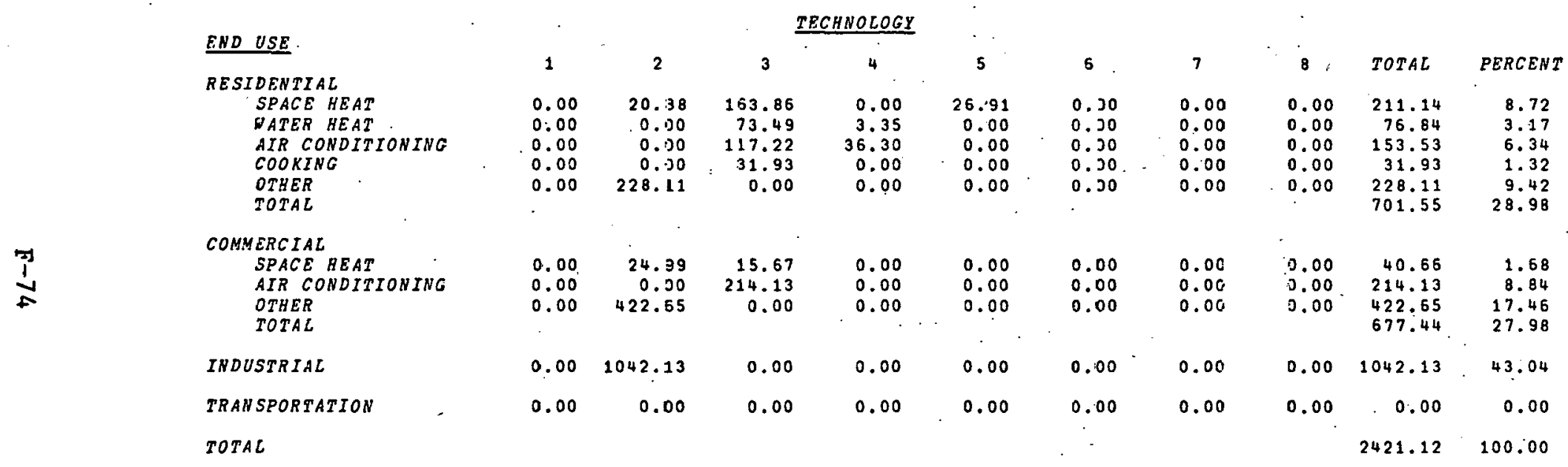

SJMNARY OUTEUTS -- SOUTH CENTRAL 2000 1/8/80

25 PERCENT SOLAR PENETRATION WITH 20 PFRCENT SPACE HEAT REPLACEMENTS

\begin{tabular}{|c|c|c|c|c|c|c|c|c|c|c|c|c|}
\hline & WIHTER & $\begin{array}{l}\text { LOAD EAE } \\
\text { SUMNER }\end{array}$ & $\begin{array}{l}\text { TORS } \\
A \cup U T / S P R\end{array}$ & $A N N \cup A C$ & $\begin{array}{l}\text { SEASONAL } \\
\text { SUN/WIN }\end{array}$ & $\begin{array}{c}\text { PEAK RATIOS } \\
\text { SPR /WIN }\end{array}$ & $\begin{array}{l}\text { EROWTH } \\
\text { ENERGY }\end{array}$ & $\begin{array}{l}\text { RATES } \\
\text { PEAK }\end{array}$ & $\begin{array}{c}\text { CUBULATIVE } \\
15\end{array}$ & $\begin{array}{c}\angle O A D \\
30\end{array}$ & $\begin{array}{c}\text { CAPACITY } \\
50\end{array}$ & $\begin{array}{c}\text { EACTOR } \\
70\end{array}$ \\
\hline BASE CASE & 0.567 & 0.526 & 0.743 & c. 471 & 1.425 & 0.823 & 3.12 & 3.68 & 0.400 & 0.450 & 0.520 & 0.630 \\
\hline SCENARIO & 0.553 & 0.524 & $0.74 \varsigma$ & 0.476 & 1.340 & 0.775 & 3.14 & 3.64 & 0.400 & 0.440 & 0.520 & 0.630 \\
\hline DIPFERENCE & -0.314 & -0.003 & 0.005 & $c .005$ & -0.084 & -0.048 & 0.02 & -0.03 & 0.000 & -0.010 & 0.000 & 0.000 \\
\hline PERCENTACE & -2.2 & -0.5 & 0.7 & 1.1 & -5.9 & -5.8 & 0.7 & -0.9 & 0.0 & -2.2 & 0.0 & 0.0 \\
\hline
\end{tabular}


Case 24: Electric Car -- Day and Night Charging

Assumptions: As in Case 16, 10\% of all vehicle miles are assumed to be driven in electric cars. However, the charging pattern is assumed to be perfectly flat throughout the day and night.

Results :

The increase in annual load factor is about half of that in Case 16. Clearly, a flat load does not increase load factors as much as an off-peak charging load. 


\section{Table F-26}

RESULTS OF SENSITIVITY CASE 24

ELECTRIC CAR - DAY AND NIGHT CHARGING - 10 PERCENT PENETRATION

$$
\left(10^{12} \mathrm{Btu} / \mathrm{Yr}\right)
$$

a. North Central Regicn

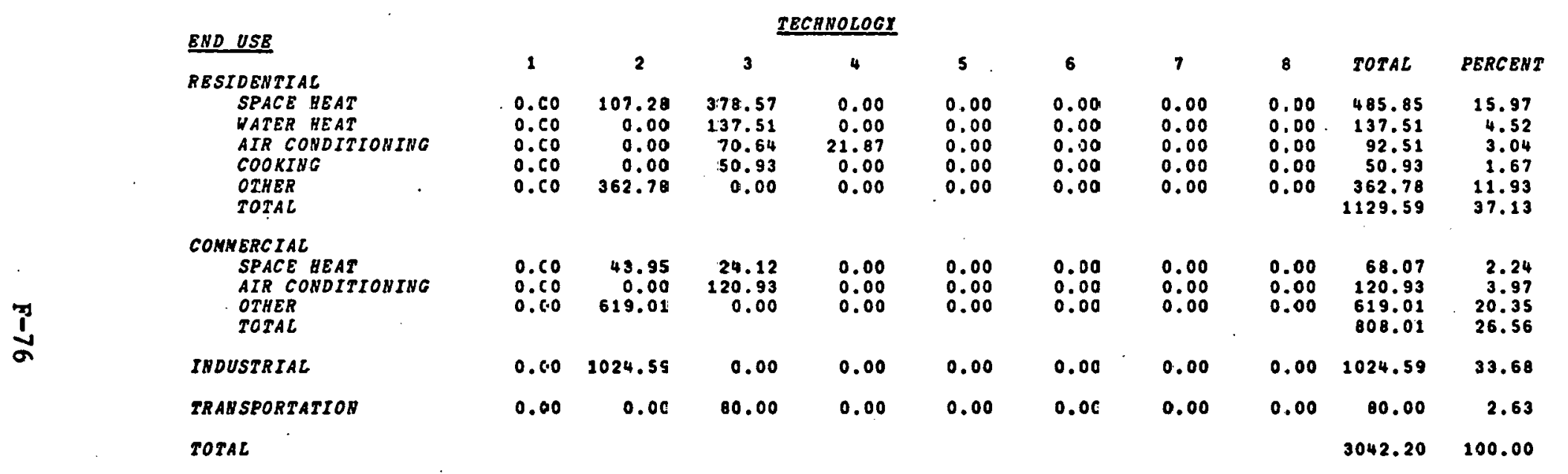

SUMARY OATPUTS - NORTH CEITRAL $2000 \quad 12 / 31: 79$

ELEETRIC CAR - DAY AND HIGHT CHARGING - 10 PERCEDT PEMBTAATION

\begin{tabular}{|c|c|c|c|c|c|c|c|c|c|c|c|c|}
\hline & WIETER & $\begin{array}{l}\text { ZOAD } P A C \\
\text { SUNK } Z R\end{array}$ & $\begin{array}{l}\text { TORS } \\
\text { AUT/SPR }\end{array}$ & ARIUAC & $\begin{array}{l}\text { SBASONAL } \\
\text { SUN/WIA }\end{array}$ & $\begin{array}{l}\text { BAK RATIOS } \\
\text { SPR/HIB }\end{array}$ & $\begin{array}{l}\text { GROWTA } \\
\text { BAERGY }\end{array}$ & $\begin{array}{r}\text { RATSS } \\
\text { PEAK }\end{array}$ & $\underset{15}{\text { CUNULATIVE }}$ & $\begin{array}{c}8 \angle O A D \\
30\end{array}$ & $\begin{array}{c}B Y \text { CAPACITY } \\
50\end{array}$ & $\begin{array}{c}\text { PACTOR } \\
70\end{array}$ \\
\hline BASE CASE & 0.652 & 0.516 & 0.788 & 0.546 & 1.041 & 0.688 & 2.34 & 3.13 & 0.300 & 0.370 & 0.430 & 0.540 \\
\hline SCEAABIO & 0.657 & 0.524 & 0.792 & 0.552 & 1.040 & 0.693 & 2.37 & 3.20 & 0,300 & 0.370 & 0.420 & 0.530 \\
\hline DIEPBREACE & 0.005 & 0.001 & 0.003 & 0.006 & -0.001 & 0.005 & 0.14 & 0.07 & 0.000 & 0.000 & -0.010 & -0.020 \\
\hline PERCEITAGE & 0.8 & 2.4 & 0.4 & 1.2 & -0.1 & 0.7 & 4.8 & 2.4 & 0.0 & 0.0 & -2.3 & -1.9 \\
\hline
\end{tabular}


Table F-26, Continued

\section{b. South Central Region}

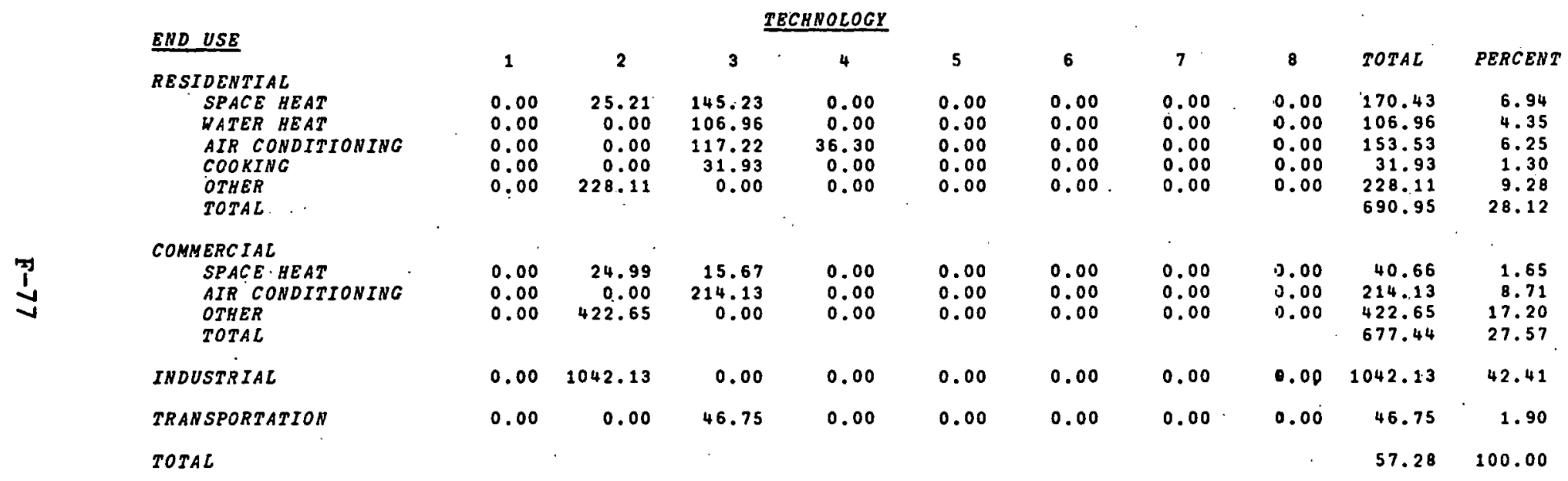

SUMMARY OUTPUTS -- SOUTH CENTRAL 2000 1/8/80

ELECTRIC CAR - DAY AND NIGHT CBARGING - 10 PERCENS PENETRATION

\begin{tabular}{|c|c|c|c|c|c|c|c|c|c|c|c|c|}
\hline & WINTER & $\begin{array}{l}-O A D P A C ? \\
\text { SUMMER }\end{array}$ & $\begin{array}{l}\text { TORS } \\
\text { AUT/SPR }\end{array}$ & $A N N U A L$ & $\begin{array}{c}\text { SEASONAL } \\
\text { SUM/WIN }\end{array}$ & $\begin{array}{c}\text { PEAK RATIOS } \\
\text { SPR/WIN }\end{array}$ & $\begin{array}{l}\text { GROHTH } \\
\text { ENERGY }\end{array}$ & $\begin{array}{l}\text { RATES } \\
\text { PEAK }\end{array}$ & $\begin{array}{c}\text { CUMULATIVE } \\
15\end{array}$ & $\begin{array}{c}E \angle O A D \\
30\end{array}$ & $\begin{array}{c}B Y C A P A C I T Y \\
50\end{array}$ & $\begin{array}{c}\text { BACTOR } \\
70\end{array}$ \\
\hline$B A S E$ CASE & 0.667 & 0.526 & 0.743 & 0.471 & 1.425 & 0.823 & 3.12 & 3.68 & 0.400 & 0.450 & 0.520 & 0.630 \\
\hline SCENARIO & 0.672 & 0.531 & 0.748 & 0.476 & 1.419 & 0.826 & 3.22 & 3.72 & 0.390 & 0.440 & 0.510 & 0.630 \\
\hline DIFFERENCE & 0.005 & 0.005 & 0.005 & $0.005:$ & -0.006 & 0.002 & 0.10 & 0.05 & -0.010 & -0.010 & -0.010 & 0.000 \\
\hline PERCENTAGE & 0.7 & 0.9 & 0.7 & 1.1 & -0.4 & 0.3 & 3.2 & 1.3 & -2.5 & -2.2 & -1.9 & 0.0 \\
\hline
\end{tabular}


Appendix G

OUTPUTS OF LOAD MANAGEMENT ANALYSIS RUNS

This appendix contains the output of load management cases 1 through 12 in the same format as Appendix $F$. 
KEY TO TECHNOLOGIES IN TABLES OF RESULTS

\section{END USE}

\section{Residential}

Space Heat.

Ẉater Heat

A1r Conditioning

Cooking

Other

\section{Commerclal}

Space Heat

Alr Conditioning

Other

Industr1a1

Transportation (Automobile)
TECHNOLOGY

\begin{tabular}{|c|c|c|c|c|}
\hline 4 & 5 & 6 & 7 & 8 \\
\hline $\begin{array}{l}\text { Electric } \\
\text { Keat Pump }\end{array}$ & Sol.ar & $\begin{array}{l}\text { Resistance } \\
\text { w/Storage }\end{array}$ & $\begin{array}{l}\text { Dual-fueled } \\
\text { Heat Pump. }\end{array}$ & $\begin{array}{l}\text { Dual-fueled } \\
\text { HP w/Storage }\end{array}$ \\
\hline Solar & $\begin{array}{l}\text { Control- } \\
\text { lable } \\
\text { Electric. }\end{array}$ & - & . & - \\
\hline $\begin{array}{l}\text { Electric } \\
\text { Room A/C }\end{array}$ & $\begin{array}{l}\text { Electric } \\
\text { Heat Pump }\end{array}$ & $\begin{array}{l}\text { Central } \\
\text { w/Storage }\end{array}$ & - & - \\
\hline- & - & - & - & - \\
\hline
\end{tabular}

Electric

Heat Pump

Furnace Fesistance

Electric

Electric Central

Heat Pump

Central $w /$ Storage

No Appliance

Electric

$\therefore$

Unmanaged Managed

Electric Electric

Interruptible

Service

Gasoline Electric

No Appllance

Hectric


Case 1: Controls on All New and Replacement Residential Electric Hot Water, Heaters

Assumptions: All new installations and replacements that would normally be conventional electric resistance are replaced by controlled. electric resistance water heaters. The effect of the control is estimated using the load management (customer storage) algorithm.

Results:

All seasonal load factors increase by about 1 or $2 \%$. The annual load factor also increases by $2 \%$. The growth rate of peak demand decreases by about $4 \%$.

G-2 
Table G-1

RESULTS OF LOAD MANAGEMENT ANALYSIS CASE 1 CONTROLS ON RESIDENTIAL ELECTRIC WATER HEATERS

$$
\left(10^{12} \mathrm{Btu} / \mathrm{yr}\right)
$$

a. North Central Region

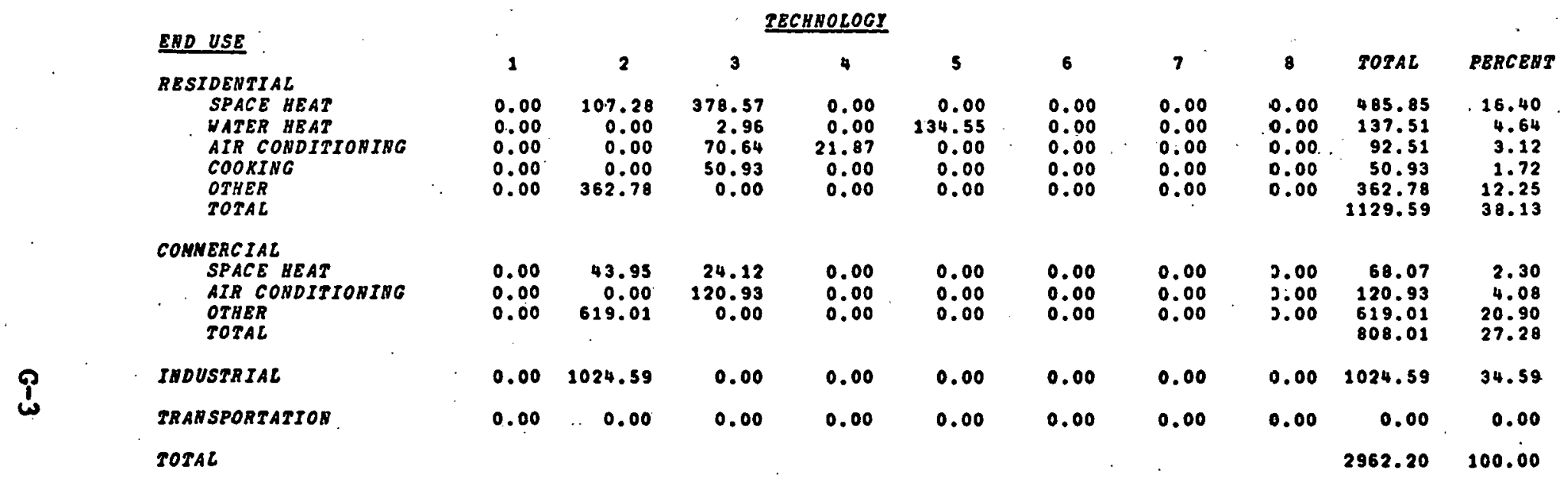

SUMNARY OUTPUTS -- MORTH GENTRAL $2000 \quad 12 / 18 / 79$ COATROLS OM RESTDEMTIAL BLECTRTC UATER BBATBRS

\begin{tabular}{|c|c|c|c|}
\hline & $\begin{array}{c}\text { COAD PAC } \\
\text { SUMNERR }\end{array}$ & $\begin{array}{l}\text { TORS } \\
\text { AUT / SPR }\end{array}$ & 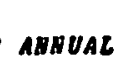 \\
\hline 652 & 0.516 & 0.780 & 0.546 \\
\hline 68 & 0.528 & 0.803 & 0.558 \\
\hline 0 & 0.011 & 0.015 & 0.012 \\
\hline
\end{tabular}

\begin{tabular}{|c|c|c|c|}
\hline $\begin{array}{l}\text { SEASORAL } \\
\text { SUH/WIN }\end{array}$ & $\begin{array}{l}\text { BAR RATIOS } \\
\text { SPR /UIE }\end{array}$ & $\begin{array}{l}\text { GROWTE } \\
\text { BNERGY }\end{array}$ & $\begin{array}{r}\text { RATES } \\
\text { PEAX }\end{array}$ \\
\hline 1.041 & 0.688 & 2.84 & 3.13 \\
\hline 1.032 & 0.684 & 2.84 & 3.01 \\
\hline 0.009 & $=0.004$ & 0.00 & -0.11 \\
\hline-0.8 & -0.6 & 0.0 & -3.6 \\
\hline
\end{tabular}

$\begin{array}{cccc}\begin{array}{c}\text { CUNULATIVB } \\ 15\end{array} & \begin{array}{c}\text { COAD } \\ 15\end{array} & \begin{array}{c}\text { BI CAPACIFI } \\ 50\end{array} & \begin{array}{c}\text { PACTOR } \\ 10\end{array} \\ 0.300 & 0.370 & 0.430 & 0.340 \\ 0.300 & 0.370 & 0.420 & 0.330 \\ 0.000 & 0.000 & -0.010 & -0.010 \\ 0.0 & 0.0 & -2.3 & -1.9\end{array}$


Table G-1, Continued

b. South Central Region

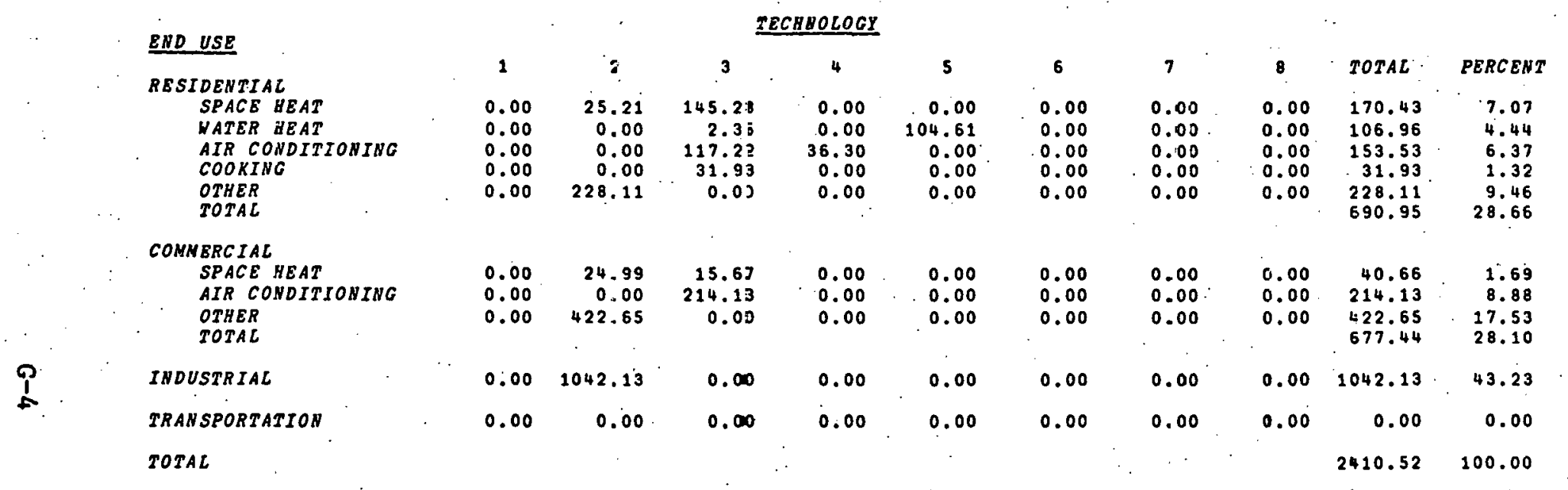

SUMMARY OUTPUTS -- SOUTH CENTRAL 2000 12/18/79

CONTROLS ON RESIDENTIAL ELECTRIC WATER BEATERS

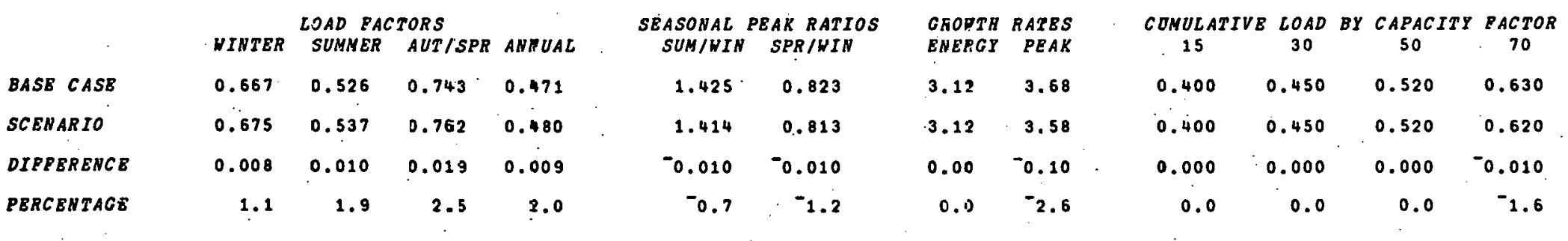


Case. 2: $\quad$ Energy Storage on Residential Electric Space Heat

As sumptions: All new installations of residential electric space heat have unlimited dally cycle heat storage capability.

Results: The winter load factor increases by a significant $18 \%$. However, since heat storage does not affect the annual peak, which occurs in summer, the annual load factor remains almost constant. 
Table G-2

RESULTS OF LOAD MANAGEMENT ANALYSIS CASE 2

ENERGY STORAGE ON RESIDENTIAL ELECTRIC SPACE HEAT

$\left(10^{12} \mathrm{Btu} / \mathrm{yr}\right)$

a. North Central Region

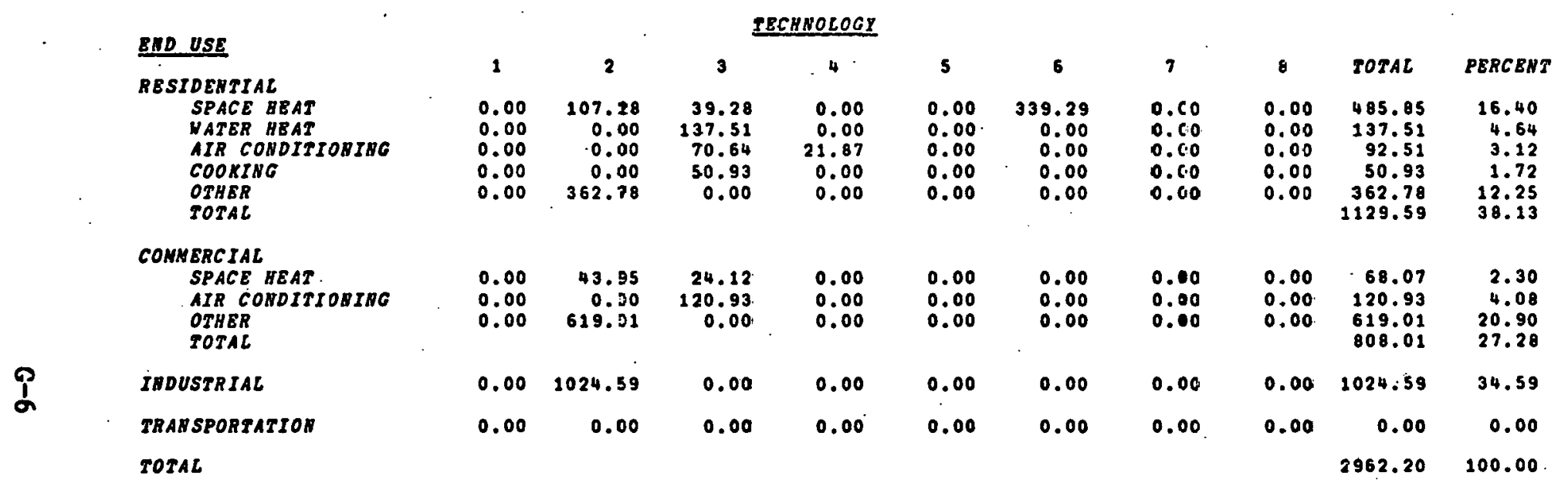

SUMMARY OUTPUTS -- BORTH CENTRAL .2000 12/18/79 ENERGY STORACB ON PESTDEHTIAL BLECTRIC SPACB HEAT

\begin{tabular}{|c|c|c|c|c|c|c|c|c|c|c|c|c|}
\hline & WINTER & $\begin{array}{c}\text { LOAD EAC } \\
\text { SUNMER }\end{array}$ & $\begin{array}{l}\text { CTORS } \\
\text { AUT / SPR }\end{array}$ & ABAJAL & $\begin{array}{l}\text { SEASOBAL } \\
\text { SUN/WIN }\end{array}$ & $\underset{S P R / W I N}{P B A K}$ & $\begin{array}{l}\text { GROWYH } \\
\text { BNEREY }\end{array}$ & $\begin{array}{l}\text { RATES } \\
\text { PEAK }\end{array}$ & $\underset{15}{\text { CUNULATIVE }}$ & $\begin{array}{c}\angle O A D \\
30\end{array}$ & $\begin{array}{c}B Y \text { CAPACITY } \\
50\end{array}$ & $\begin{array}{c}\text { PACTOR } \\
70\end{array}$ \\
\hline BASE CASE & 0.652 & 0.516 & 0.786 & 0.576 & 1.041 & 0.688 & 2.84 & 3.13 & 0.300 & 0.370 & 0.430 & 0.540 \\
\hline SCENARIO & 0.772 & 0.516 & 0.787 & 0.576 & 1.232 & 0.815 & 2.84 & 3.13 & 0.310 & 0.370 & 0.420 & 0.330 \\
\hline DIPFERENCE & 0.120 & 0.000 & -0.001 & 0.000 & 0.191 & 0.129 & 0.00 & 0.00 & 0.010 & 0.000 & -0.010 & -0.010 \\
\hline PBRCEUTAGE & 18.4 & 0.0 & -0.2 & 0.1 & 18.4 & 18.5 & 0.0 & 0.0 & 3.3 & 0.0 & -2.3 & -1.9 \\
\hline
\end{tabular}


Table G-2, Continued

b. South Central Region

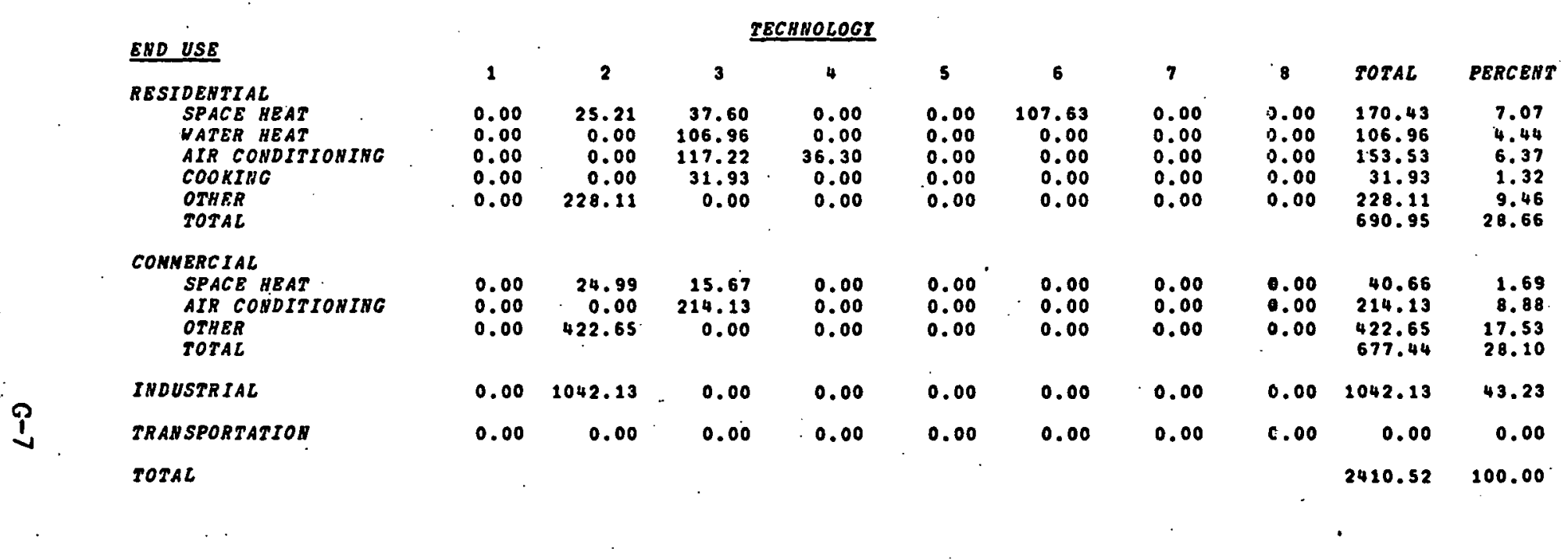

SUMAARY OUTPUTS -- SOUTR CENTRAL 2000 12/18/79
ENERGY STORAGE OH RESIDENTIAL ELECTRIC SPACE HEAT

\begin{tabular}{|c|c|c|c|c|c|c|c|c|c|c|c|c|}
\hline & WINTER & $\begin{array}{c}\text { LOAD EAC } \\
\text { SUNNER }\end{array}$ & $\begin{array}{l}\text { TORS } \\
\text { AUT / SPR }\end{array}$ & ABHUAC & $\begin{array}{l}\text { SBASONAL } \\
\text { SUN/WIM }\end{array}$ & $\begin{array}{l}\text { PEAK RATIOS } \\
\text { SPR IHIR }\end{array}$ & $\begin{array}{l}\text { GROUTR } \\
\text { ENERGY }\end{array}$ & $\begin{array}{l}\text { RATES } \\
\text { PEAK }\end{array}$ & $\begin{array}{c}\text { CUNULATIVE } \\
\text { IS }\end{array}$ & $\begin{array}{c}\angle O A D \\
30\end{array}$ & $\begin{array}{c}\text { BY CAPACITY } \\
50\end{array}$ & $\begin{array}{c}\text { EACTOR } \\
70\end{array}$ \\
\hline BASB CASB & 0.667 & 0.526 & 0.743 & 0.471 & 1.425 & 0.823 & 3.12 & 3.68 & 0.400 & 0.450 & 0.520 & 0.630 \\
\hline SCEBARIO & 0.736 & 0.526 & 0.747 & 0.472 & 1.571 & 0.905 & 3.12 & 3.68 & 0.390 & 0.450 & 0.520 & 0.630 \\
\hline DIPFERENCE & 0.068 & 0.000 & 0.003 & 0.001 & 0.146 & 0.082 & 0.00 & 0.00 & -0.010 & 0.000 & 0.000 & 0.000 \\
\hline PERCENTAGE & 10.2 & 0.0 & 0.4 & 0.1 & 10.3 & 9.9 & 0.0 & 0.0 & -2.5 & 0.0 & 0.0 & .0 .0 \\
\hline
\end{tabular}


Case 3: . Energy Storage on Commercial Air Conditioning

Assumptions: One-half of all new installations of commerctal air conditioning have cool storage capability.

Results: The summer load factor is increased by more than $8 \%$, while the annual load factor is increased by $4 \%$. The system becomes slightly winter peaking. 
Table G-3

RESULTS OF LOAD MANAGEMENT ANALYSIS CASE 3

ENERGY STORAGE ON COMMERCIAL AIR CONDITIONING

$$
\left(10^{12} \mathrm{Btu} / \mathrm{yr}\right)
$$

a. North Central Region

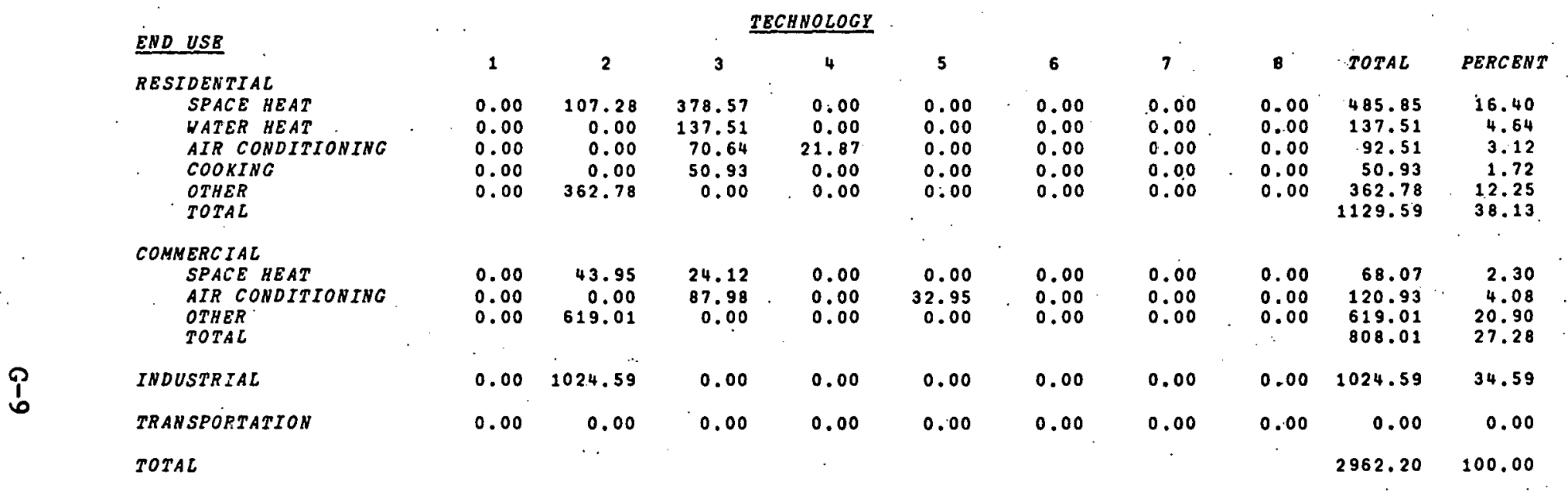

SUMMARY OUTPUTS -- NORTH CENTRAL $2000 \quad 12 / 18 / 79$ ENERGY STORAGE ON COMMERCIAL AIR CONDITIONING

\begin{tabular}{|c|c|c|c|c|c|c|c|c|c|c|c|c|}
\hline & WINTER & $\begin{array}{c}\angle O A D \quad F A C \\
\text { SUMMER }\end{array}$ & $\begin{array}{l}\text { CTORS } \\
\text { AUT / SPR }\end{array}$ & ANNUAL & $\begin{array}{l}\text { SEASONAL } \\
\text { SUM/WIN }\end{array}$ & $\begin{array}{c}P B A K \text { RATIOS } \\
\text { SPR/WIN }\end{array}$ & $\begin{array}{l}\text { GRONTH } \\
\text { ENERGY }\end{array}$ & $\begin{array}{c}\text { RATES } \\
\text { PEAK }\end{array}$ & $\begin{array}{c}\text { CUNULATIVL } \\
15\end{array}$ & $\begin{array}{c}Y B \quad \angle O A D \\
30\end{array}$ & $\begin{array}{c}B Y C A P A C I T Y \\
50\end{array}$ & $\begin{array}{c}\text { Y EACTOR } \\
70\end{array}$ \\
\hline BASE CASE & 0.652 & 0.516 & 0.788 & 0.546 & 1.041 & 0.688 & 2.84 & 3.13 & 0.300 & 0.370 & 0.430 & 0.540 \\
\hline SCENARIO & 0.652 & 0.561 & 0.788 & 0.568 & 0.960 & 0.688 & 2.84 & 2.92 & 0.280 & 0.350 & 0.410 & 0.520 \\
\hline DIFRERENCE & 0.000 & 0.044 & -0.000 & 0.022 & -0.081 & 0.000 & 0.00 & -0.21 & -0.020 & -0.020 & -0.020 & -0.020 \\
\hline PERCENTAGE & 0.1 & 8.5 & -0.1 & 4.1 & -7.7 & 0.0 & 0.0 & -6.6 & -6.7 & -5.4 & -4.7 & -3.7 \\
\hline
\end{tabular}


Table G-3, Continued

b. South Central Region

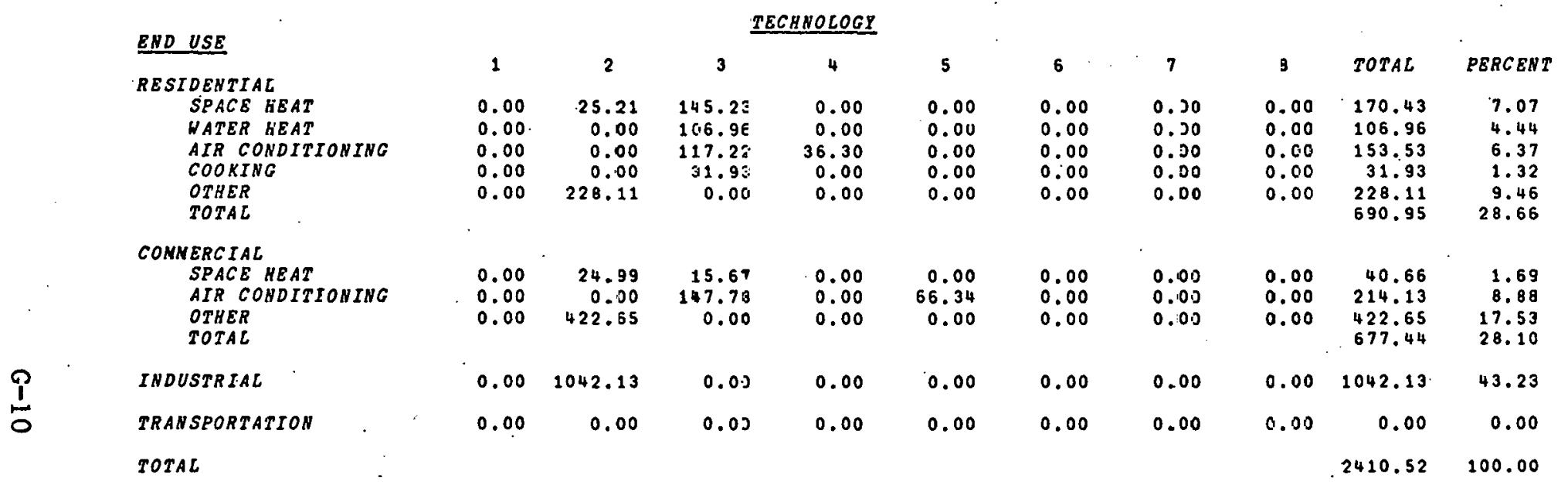

SUMMARY OUTPUTS -- SOUTH CENTRAL $2000 \quad 12 / 18 / 79$

ENERGY STORAGE ON COMMERCIAL AIR CONDITIONING

\begin{tabular}{|c|c|c|c|c|c|c|c|c|c|c|c|c|}
\hline . & WINTER & $\begin{array}{l}\text { LOAD } P A C \\
\text { SUMMER }\end{array}$ & $\begin{array}{l}\text { TORS } \\
A U T / S P R\end{array}$ & ANTUAL & $\begin{array}{l}\text { SEASONAL } \\
\text { SUM/WIN }\end{array}$ & $\begin{array}{c}\text { PEAK RATIOS } \\
\text { SPR/WIN }\end{array}$ & $\begin{array}{l}\text { GRORTH } \\
\text { ENERGY }\end{array}$ & $\begin{array}{r}\text { RATES } \\
\text { PEAK }\end{array}$ & $\begin{array}{l}\text { CUNULATIVE } \\
15\end{array}$ & $\begin{array}{c}B \quad \angle O A D \\
30\end{array}$ & $\begin{array}{c}\text { BY CAPACITY } \\
50\end{array}$ & $\begin{array}{c}\text { Y FACTOR } \\
70\end{array}$ \\
\hline$B A S E \quad C A S E$ & 0.667 & 0.526 & 0.743 & 0.471 & 1.425 & 0.823 & 3.12 & 3.68 & 0.400 & 0.450 & 0.520 & 0.630 \\
\hline SCENARIO & 0.667 & 0.585 & 0.749 & 0.524 & 1.282 & 0.818 & 3.12 & 3,13 & 0.360 & 0.390 & 0.470 & $0.570^{\circ}$ \\
\hline DIREERENCB & -0.000 & 0.059 & 0.005 & 0.053 & -0.142 & -0.005 & 0.00 & -0.54 & -0.040 & -0.060 & -0.050 & -0.060 \\
\hline PERCENTAGE & -0.0 & 11.2 & 0.7 & 11.2 & $-i 0.0$ & -0.6 & 0.0 & -14.8 & -10.0 & -13.3 & -9.6 & -9.5 \\
\hline
\end{tabular}


Case 4: Management of 25\% of Industrial Energy Use

Assumptions: Twenty-five percent of the industrial load is redistributed by the load management model.

Results: The annual load factor increases by over 5\%. The system remains evenly balanced between summer and winter. 
Table G-4

RESULTS OF LOAD MANAGEMENT ANALYSIS CASE 4

LOAD MANAGEMENT OF 25 PERCENT OF INDUSTRIAL ENERGY USE

$$
\left(10^{12} \mathrm{Btu} / \mathrm{yr}\right)
$$

\section{a. North Central Region}

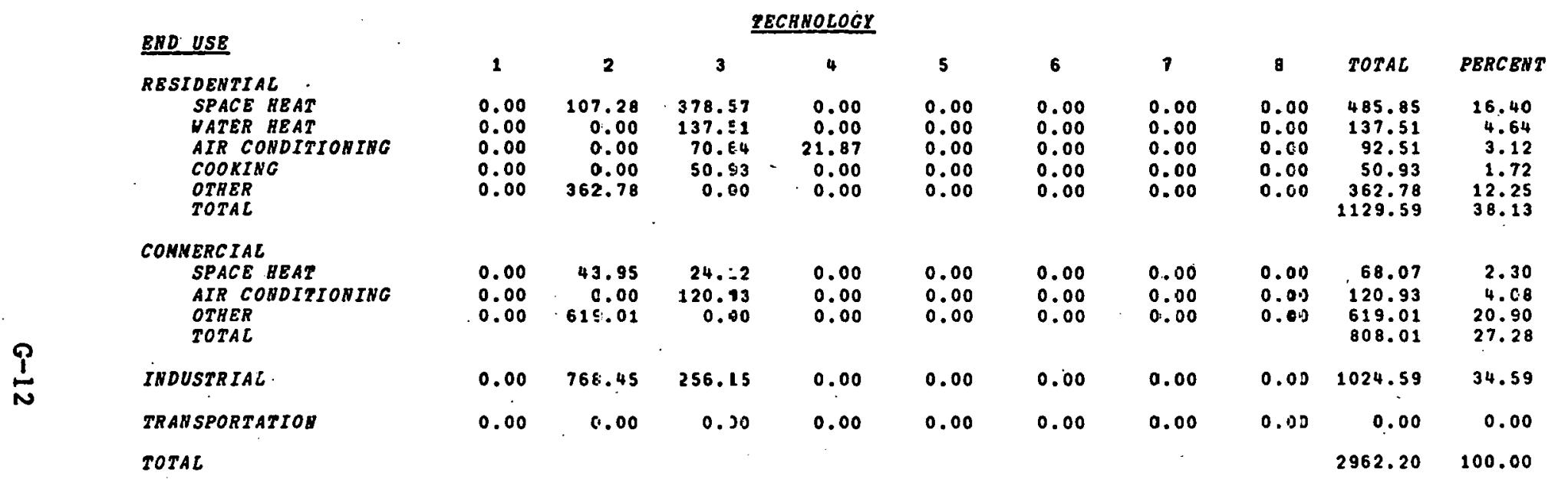

SUANARI OUTPUTS - NORTH CENTRAL $2000 \quad 12 / 18 / 79$

LOAD MAHAGENENT OP 25 PERCENT OF INDUSTRIAL ENERGY ISE

\begin{tabular}{|c|c|c|c|c|c|c|c|c|c|c|c|c|}
\hline & WINTER & $\begin{array}{l}\text { COAD EAC } \\
\text { SUMMER }\end{array}$ & $\begin{array}{l}\text { TORS } \\
\text { AUT } \triangle S P R\end{array}$ & $A B N U A L$ & $\begin{array}{l}\text { SEASONAL } \\
\text { SUM/WIN }\end{array}$ & $\begin{array}{c}\text { PEAK RATIOS } \\
\text { SPR /WIN }\end{array}$ & $\begin{array}{l}\text { GRCWTA } \\
\text { ENERGY }\end{array}$ & $\begin{array}{r}\text { RATES } \\
\text { PEAK }\end{array}$ & $\underset{15}{\text { CUNULATIVI }}$ & $\begin{array}{c}E C O A D \\
30\end{array}$ & $\begin{array}{c}B Y \text { CAPACITY } \\
50\end{array}$ & $\begin{array}{c}\text { PACTOR } \\
70\end{array}$ \\
\hline BASE CASE & 0.652 & 0.526 & $0.7 B 8$ & 0.546 & 1.041 & 0.688 & 2.04 & 3.13 & 0.300 & 0.370 & 0.430 & 0.540 \\
\hline SCENARIO & 0.673 & 0.543 & 0.813 & 0.574 & 1.021 & 0.689 & 2.04 & 2.86 & 0.290 & 0.350 & 0.400 & 0.500 \\
\hline DIFEERENCE & 0.021 & 0.027 & 0.025 & 0.028 & -0.020 & 0.001 & 0.00 & -0.26 & -0.010 & -0.020 & -0.030 & -0.040 \\
\hline PERCENTAGE & 3.2 & 5.2 & 3.2 & 5.2 & -1.9 & 0.1 & 0.0 & -8.4 & -3.3 & -5.4 & -7.0 & -7.4 \\
\hline
\end{tabular}


Table G-4, Continued

b. South Central Region

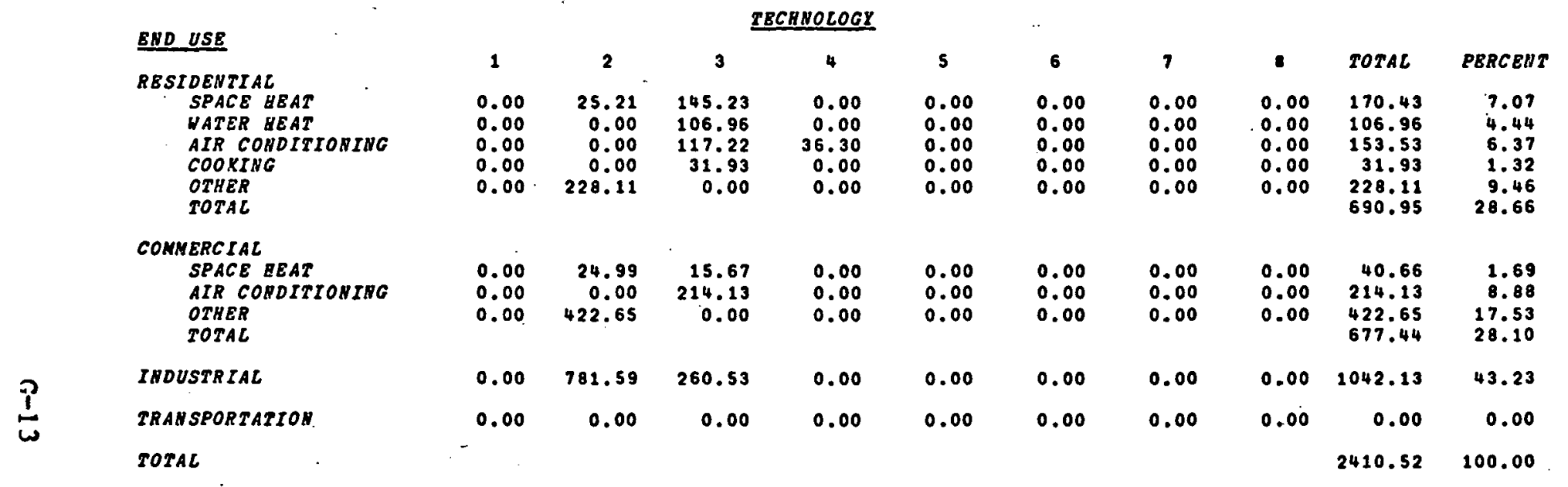

SUMNARY OUTPUTS -- SOUTH CENTRAL $2000 \quad 12 / 18 / 79$

SUHNARY OUTPUTS
LOAD MANAGENENT OE 25 PERCENT OF INDUSTRIAL ENERGY USE

\begin{tabular}{|c|c|c|c|c|c|c|c|c|c|c|c|c|}
\hline & WIUTER & $\begin{array}{c}\text { COAD RAC } \\
\text { SUMNER }\end{array}$ & $\begin{array}{l}\text { TORS } \\
\text { AUT / SPR }\end{array}$ & $A N N U_{A L}$ & $\begin{array}{l}\text { SEASONAL } \\
\text { SUN/WIN }\end{array}$ & $\begin{array}{c}\text { PEAK RATIOS } \\
\text { SPR/WIN }\end{array}$ & $\begin{array}{l}\text { GROWTH } \\
\text { ENBRGY }\end{array}$ & $\begin{array}{r}\text { RATES } \\
\text { PEAK }\end{array}$ & $\begin{array}{l}\text { C.UNULATIVE } \\
.15\end{array}$ & $\begin{array}{c}E \quad \angle O A D \\
30\end{array}$ & $\begin{array}{c}B Y C A P A C I T Y \\
50\end{array}$ & $\begin{array}{c}Y \text { PACTOR } \\
70\end{array}$ \\
\hline BASE CASE & 0.667 & 0.526 & 0.743 & 0.471 & 1.425 & 0.823 & 3.12 & 3.68 & 0.400 & 0.450 & 0.520 & 0.630 \\
\hline SCENARIO & 0.690 & 0.556 & 0.783 & 0.498 & 1.395 & 0.810 & 3.12 & 3.39 & 0.390 & 0.440 & 0.500 & 0.580 \\
\hline DIEEERENCE & 0.023 & 0.030 & 0.039 & 0.027 & -0.030 & -0.013 & 0.00 & -0.29 & -0.010 & -0.010 & -0.020 & -0.050 \\
\hline PERCENTAGE & 3.4 & 5.7 & 5.3 & 5.8 & -2.1 & -1.6 & 0.0 & -7.8 & -2.5 & -2.2 & -3.8 & -7.9 \\
\hline
\end{tabular}


Case 5: Combination of Residential, Commercial, and Industrial Load Management

Assumptions: This is a combination of all load management activities of Cases 1 through 4.

Results: The annual load factor is increased by $15 \%$ ( 8 percentage points), which is the largest increase among the load management cases. The growth rate of peak demand decreases by $23 \%$, aloo the largeet change of the load management rases. 
Table G-5

RESULTS OF LOAD MANGGEMENT ANALYSIS CASE 5

COMBINATION OF RESIDENTIAL; COMMERCIAL, AND INDUSTRIAL LOAD MANAGEMENT

$$
\left(10^{12} \mathrm{Btu} / \mathrm{yr}\right)
$$

a. North Central Region

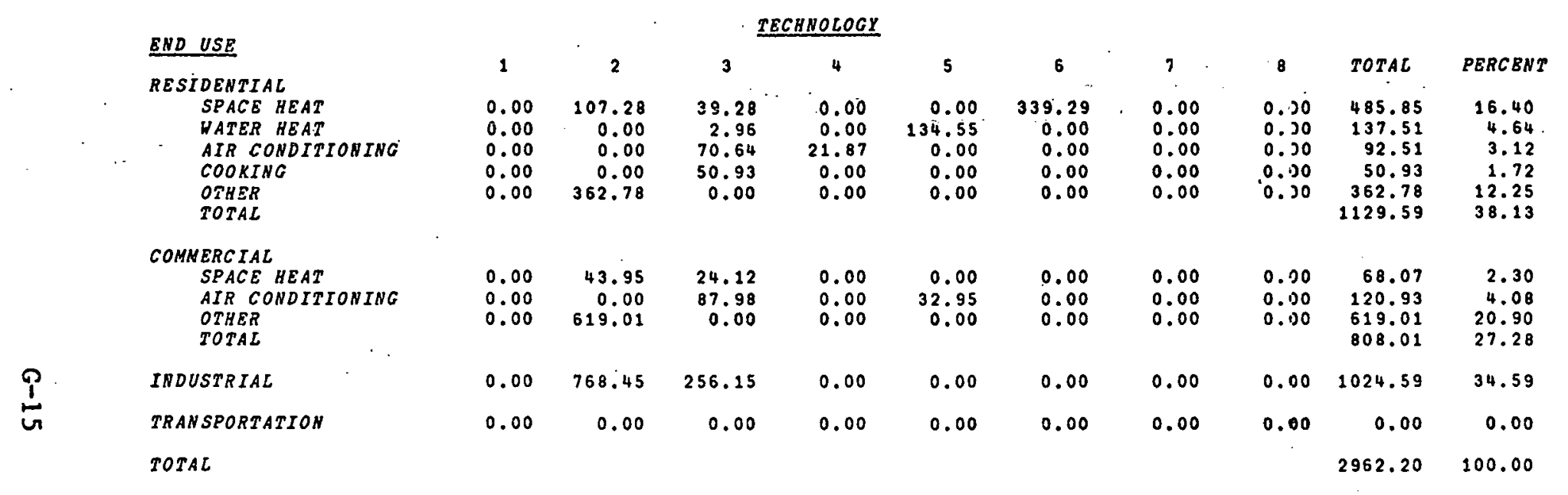

SUMNARY OUTPUTS -- NORTH CENTRAL 2000 12/18/79

CONBINATION OF RESIDENTIAL. COMMERCIAL AND INDUSTRIAL LOAD MANAGENENT

\begin{tabular}{|c|c|c|c|c|c|c|c|c|c|c|c|c|}
\hline & WINTER & $\begin{array}{c}\text { COAD } B A C \\
\text { SUMMER }\end{array}$ & $\begin{array}{l}\text { PORS } \\
\text { AUT / SPR }\end{array}$ & ANNUAL & $\begin{array}{l}\text { SEASONAL } \\
\text { SUM /WIN }\end{array}$ & $\begin{array}{l}\text { BAK RATIOS } \\
\text { SPR/WIN }\end{array}$ & $\begin{array}{l}\text { GROWTH } \\
\text { ENERGY }\end{array}$ & $\begin{array}{l}\text { RATES } \\
\text { PEAK }\end{array}$ & $\underset{15}{\text { CUNULATIVE }}$ & $B \underset{30}{L O A D}$ & $\begin{array}{c}B Y \text { CAPACITY } \\
50\end{array}$ & $\begin{array}{c}\text { EACTOR } \\
70\end{array}$ \\
\hline BASE CASE & 0.652 & 0.516 & 0.788 & 0.546 & 1.041 & 0.688 & 2.84 & 3.13 & 0.300 & 0.370 & 0.430 & 0.540 \\
\hline SCENARIO & 0.783 & 0.595 & 0.818 & 0.628 & 1.086 & 0.797 & 2.84 & 2.40 & 0.230 & 0.310 & 0.340 & 0.440 \\
\hline DIPFERENCE & 0.131 & 0.079 & 0.030 & 0.083 & 0.045 & 0.109 & 0.00 & -0.73 & -0.070 & -0.060 & -0.090 & -0.100 \\
\hline PERCENTAÉE & 20.1 & 15.2 & 3.8 & 15.1 & 4.3 & 15.8 & 0.0 & -23.3 & -23.3 & -16.2 & -20.9 & -18.5 \\
\hline
\end{tabular}


Table G-5, Continued

b. South Central Region

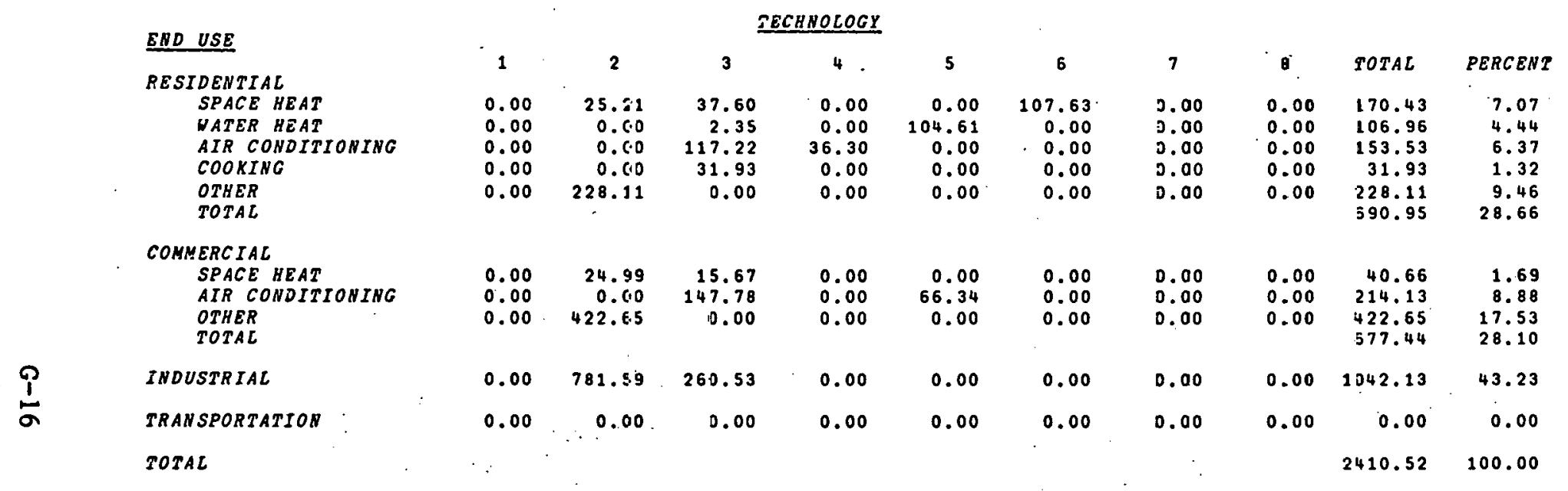

SUMMARY CUTPUTS -- SOUTH CENTRAL 2000 12/18/79

COMBINATJON OF RESIOENTIAL. COMMERCIAL AND INDUSTRIAL LOAD. MANAGSYENT

\begin{tabular}{|c|c|c|c|c|c|c|c|c|c|c|c|c|}
\hline . & WINTER & $\begin{array}{l}\text { LOAD EAC } \\
\text { SUMMER }\end{array}$ & $\begin{array}{l}\text { TORS } \\
\text { AUT / SPR }\end{array}$ & ANNUAL & $\begin{array}{l}\text { SEASONAL } \\
\text { SUM/WIN }\end{array}$ & $\begin{array}{c}\text { PEAK RATIOS } \\
\text { SPR / IIU }\end{array}$ & $\begin{array}{l}\text { GROWTH } \\
\text { ENERGY }\end{array}$ & $\begin{array}{r}\text { RATES } \\
\text { PEAK }\end{array}$ & $\begin{array}{l}\text { CUNULATIV } \\
. \quad 15\end{array}$ & $\begin{array}{c}E \text { E LOAD } \\
30 .\end{array}$ & $\begin{array}{c}B Y \text { CAPACITY } \\
50\end{array}$ & $\begin{array}{c}Y \text { FACTOR } \\
70\end{array}$ \\
\hline$B A S E C A S E$ & 0.667 & 0.526 & 0.743 & 0.471 & 1.425 & 0.823 & 3.12 & 3.68 & 0.400 & 0.450 & 0.520 & 0.630 \\
\hline SCENARIO & 0.759 & 0.622 & 0.796 & $0.55: 8$ & 1.368 & 0.875 & 3.12 & 2.81 & 0.330 & 0.380 & 0.440 & 0.500 \\
\hline DIPRERENCE & 0.091 & 0.096 & 0.053 & 0.087 & -0.057 & 0.052 & 0.00 & -0.87 & -0.070 & -0.070 & -0.080 & 0.130 \\
\hline PERCENTAGE & 13.7 & 18.2 & 7.1 & 18.4 & -4.0 & 6.3 & 0.0 & -23.7 & -17.5 & -15.6 & -15.4 & -20.6 \\
\hline
\end{tabular}




\section{Case 6: Energy Storage on Dual-Fueled Residential Space Heat}

Assumptions: The dual-fueled heat pump systems of Case 19 (Appendix F) are assumed to have energy storage capability.

Results: The results are almost identical to those of Case 19. The winter and fall/spring load factors are between 1 and $3 \%$ higher than in Sensitivity Case 19, but the annual load factor is the same. 
Table G-6

RESULTS OF LOAD MANAGEMENT ANALYSIS CASE 6

ENERGY STORF.GE ON DUAL-FUELED RESIDENTIAL SPACE HEAT

$$
\left(10^{12} \mathrm{Btu} / \mathrm{yr}\right)
$$

a. North Central Region

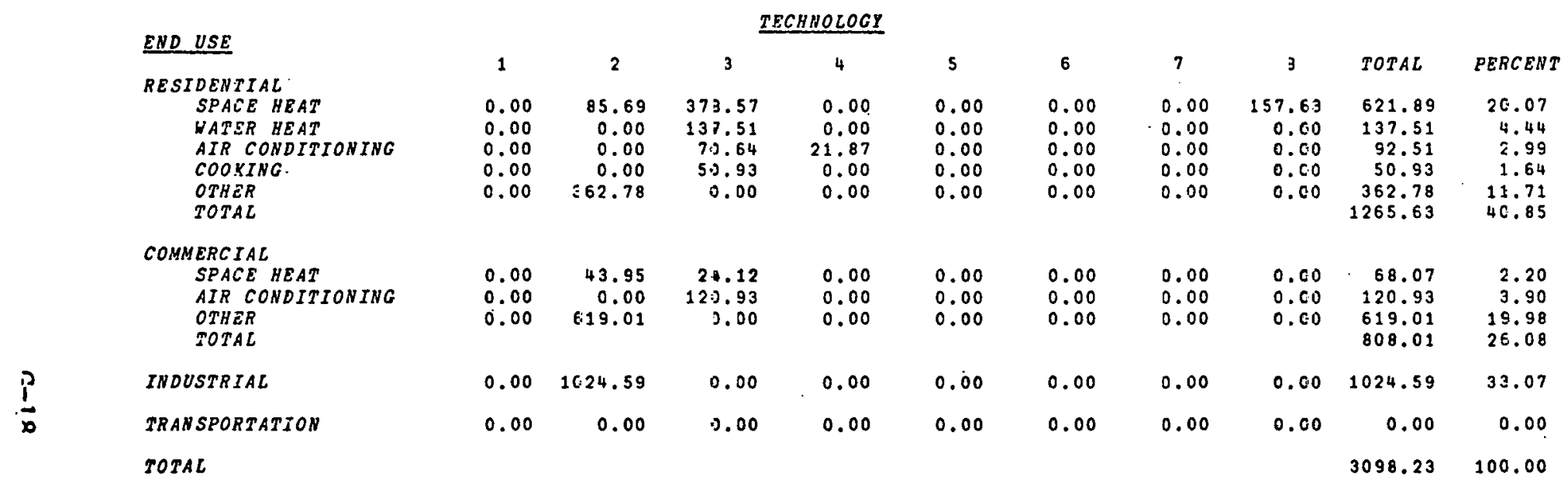

SIMMMARY OUTPUTS - . NORTH CENTRAL-2000 $1 / 8 / 80$

ENERCY STORAGE OH DUAL-FUELED RFSIDENTIAL SPACE HFAT

\begin{tabular}{|c|c|c|c|c|c|c|c|c|c|c|c|c|}
\hline & WINTER & $\begin{array}{l}\text { LOAD EA } \\
\text { SUMMER }\end{array}$ & $\begin{array}{l}\text { TOFS } \\
\text { ACT / SPR }\end{array}$ & ANNUAL & $\begin{array}{l}\text { SEASONAL } \\
\text { SUN/WIN }\end{array}$ & $\begin{array}{c}\text { PEAK RATIOS } \\
\text { SPR /WIN }\end{array}$ & $\begin{array}{l}\text { GROWPH } \\
\text { BNERGY }\end{array}$ & $\begin{array}{r}\text { RATES } \\
\text { PEAK }\end{array}$ & $\begin{array}{c}\text { CUMULATIVL } \\
15\end{array}$ & $\begin{array}{c}C O A D \\
30\end{array}$ & $\begin{array}{c}B Y C A P A C I T Y \\
50\end{array}$ & $\begin{array}{c}\text { PACTOR } \\
70\end{array}$ \\
\hline$B A S E$ CASE & 0.652 & 0.516 & 0.788 & 0.5415 & 1.041 & 0.688 & 2.84 & 3.13 & 0.300 & 0.370 & 0.430 & 0.540 \\
\hline SCENARIO & 0.687 & 0.516 & 0.814 & 0.571 & 1.040 & 0.716 & 3.07 & 3.13 & 0.280 & 0.350 & 0.400 & 0.510 \\
\hline DIPFERENCE & 0.035 & 0.000 & 0.026 & 0.02 .0 & -0.001 & 0.029 & 0.23 & 0.00 & -0.020 & -0.020 & -0.030 & -0.030 \\
\hline PERCENTAGE & 5.4 & 0.0 & 3.3 & 4.3 & -0.1 & 4.1 & B. 1 & 0.0 & -6.7 & -5.4 & -7.0 & -5.6 \\
\hline
\end{tabular}


Table G-6, Continued

b. South Central Region

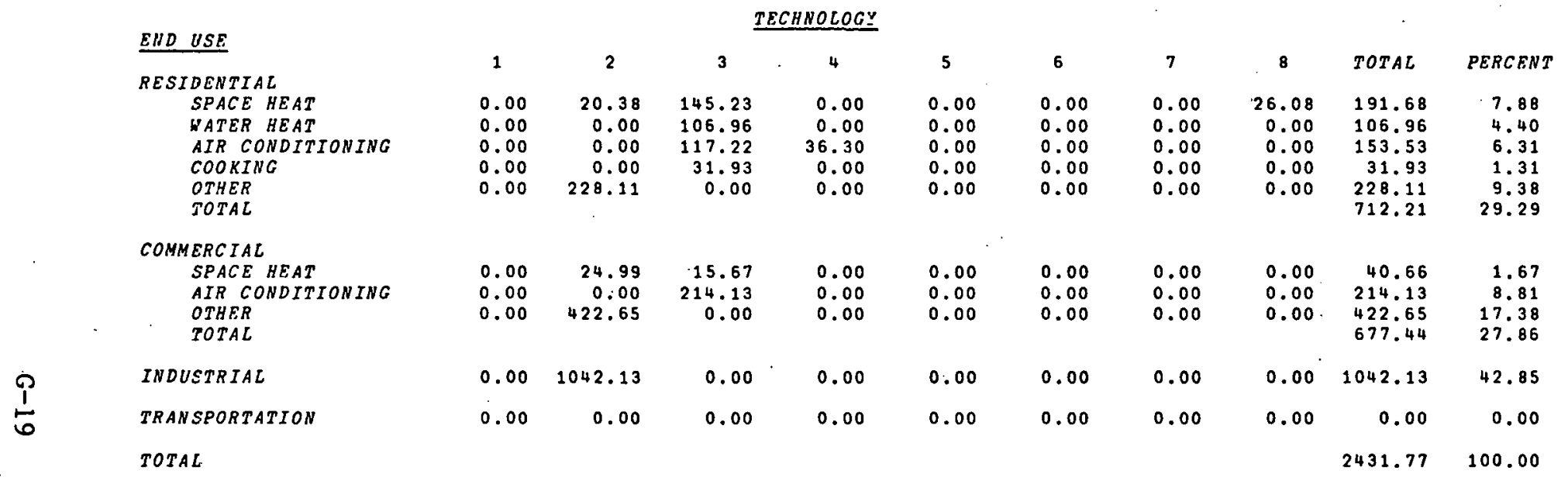

SUMMARY OUTPUTS -- SOUTH CENTRAL 2000 1/8/80

ENERGY STORAGE ON DUAL FUELED RESIDENTIAL SPACE HEAT

\begin{tabular}{lrrrr} 
& \multicolumn{5}{c}{ COAD PACTORS } \\
& NINTER & \multicolumn{1}{c}{ SUMMER } & AUT/SPR & ANNUAL \\
BASE CASE & 0.667 & 0.526 & 0.743 & 0.471 \\
SCENARIO & 0.676 & 0.526 & 0.753 & 0.475 \\
DIFFERENCE & 0.009 & 0.000 & 0.009 & 0.004 \\
PERCENTAGE & 1.4 & 0.0 & 1.2 & 0.9
\end{tabular}
SEASONAL PEAK RATIOS
SUM/WIN SPR/WIN

$\begin{array}{ll}1.425 & 0.823 \\ 1.430 & 0.832\end{array}$

$0.006 \quad 0.008$

$0.4 \quad 1.0$
GROHTH RATES FNERGY PEAK

$3.12 \quad 3.68$

$3.16 \quad 3.68$

$0.05 \quad 0.00$ $\begin{array}{cccc}\text { CUMULATIVE } & \text { LOAD } & \text { BY CAPACITY } & \text { FACTOR } \\ 15 & 30 & 50 & 70\end{array}$

$\begin{array}{rrrr}0.400 & 0.450 & 0.520 & 0.630 \\ 0.400 & 0.440 & 0.510 & 0.630 \\ 0.000 & -0.010 & -0.010 & 0.000 \\ 0.0 & -2.2 & -1.9 & 0.0\end{array}$


Case 7: . Time-of-Use Pricing \#1

Assumptions: All end uses and technologies are assumed to have an hourly price elasticity of approximately .1 .

Results: The annual load factor increases by $2 \%$. The growth rate in peak demand drops by $3.6 \%$. 
Table G-7

RESULTS OF LOAD MANAGEMENT ANALYSIS CASE 7

TIME OF USE PRICES, ELASTICITY $=.1$

$\left(10^{12} \mathrm{Btu} / \mathrm{yr}\right)$

a. North Central Region

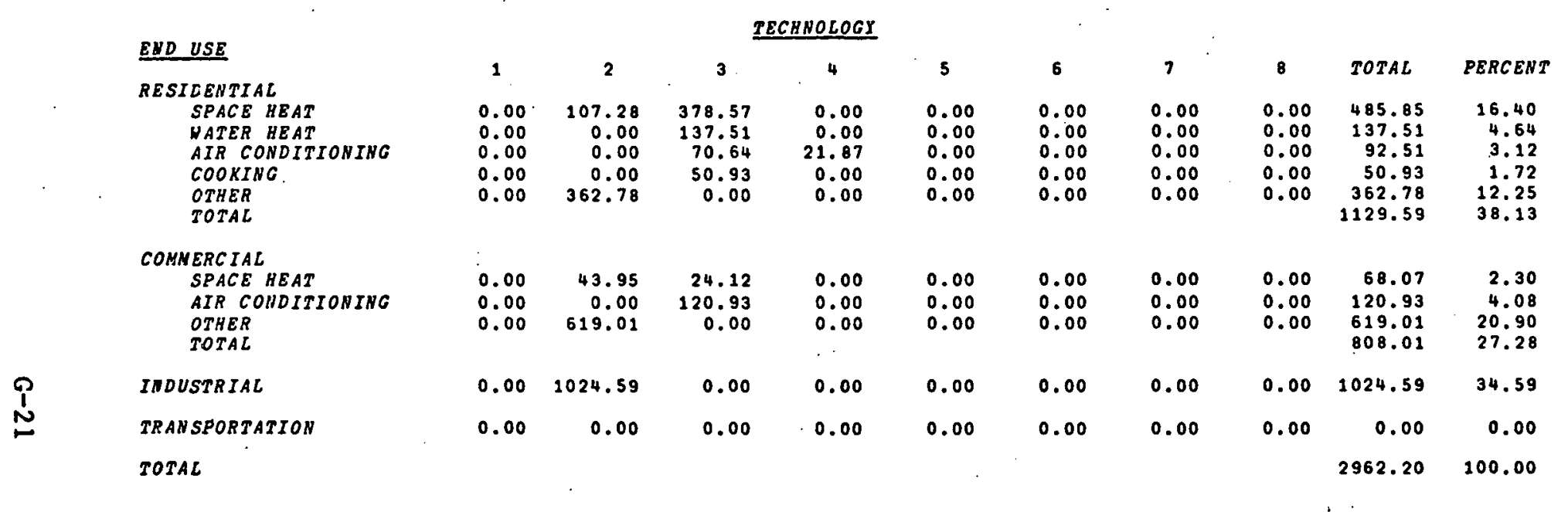

SUMMARY OUTPUTS -- DORTH CENTRAL $2000 \quad 12 / 18 / 79$ TIME OP USE PRICES, BLASTICITY $=.1$

\begin{tabular}{lrrrrr} 
& \multicolumn{5}{c}{$L O A D$ EACTORS } \\
& WINTER & \multicolumn{3}{c}{ SUNMER } & \multicolumn{1}{l}{ AUT/SPR ANNUAL } \\
BASE CASE & 0.652 & 0.516 & 0.788 & 0.546 \\
SCENARIO & 0.671 & 0.528 & 0.822 & 0.557 \\
DIFEERENCE & 0.019 & 0.011 & 0.034 & 0.011 \\
PERCENTAGE & 2.9 & 2.2 & 4.3 & 2.1
\end{tabular}
SEASONAL PEAK RATIOS
SUM/WIN SPR/WIN

1.0410 .688

$1.048 \quad 0.678$

$0.007 \quad-0.009$

$0.6 \quad-1.4$
GRONTH RATES ENERGY PEAK

$2.84 \quad 3.13$

$2.84 \quad 3.01$

$0.00 \quad-0.11$

$0.0 \quad-3.6$
CUMULATIVE LOAD BY CAPACITY PACTOR

15 30 $50 \quad 70$

$\begin{array}{llll}0.300 & 0.370 & 0.430 & 0.540\end{array}$

$\begin{array}{llll}0.300 & 0.360 & 0.420 & 0.520\end{array}$

$\begin{array}{llll}0.000 & -0.010 & -0.010 & -0.020\end{array}$ 
Table G-7, Continued

\section{b. South Central Region}

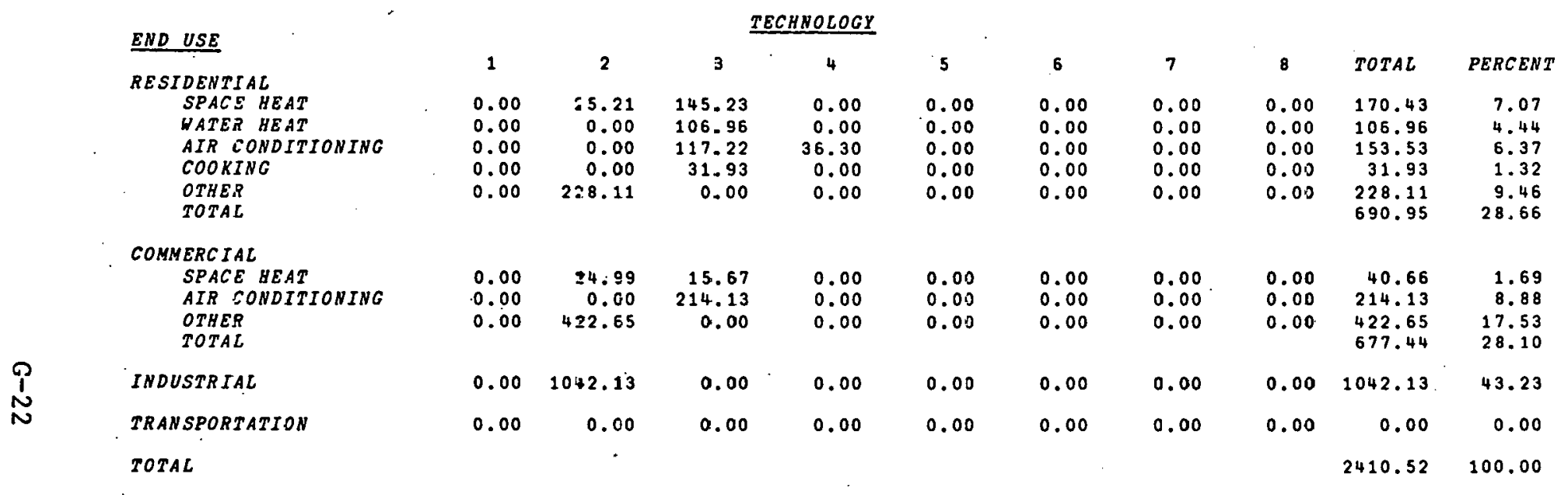

SUMMARY OUTPUTS -- SOUTH CENTRAL 2000 12/18/79 TIME OF USE PRICES, ELASTICITY $=.1$

\begin{tabular}{|c|c|c|c|c|c|c|c|c|c|c|c|c|}
\hline - & WINTER & $\begin{array}{c}\text { LOAD FAC } \\
\text { SUMMER }\end{array}$ & $\begin{array}{l}\text { TOR'S } \\
\text { AUT'SPR }\end{array}$ & ANNUA L & $\begin{array}{l}\text { SEASONAL } \\
\text { SUM/WIN }\end{array}$ & $\begin{array}{c}\text { PEAK RATIOS } \\
\text { SPR/WIN }\end{array}$ & $\begin{array}{l}\text { GROWTR } \\
\text { ERER.SY }\end{array}$ & $\begin{array}{r}R A T E S \\
P E A K\end{array}$ & $\begin{array}{c}\text { CUMULATIVE } \\
15\end{array}$ & $\begin{array}{c}E L O A D B Y \\
30\end{array}$ & $\begin{array}{c}\text { CAPACITY } \\
50\end{array}$ & $\begin{array}{c}\text { PACTOR } \\
70\end{array}$ \\
\hline BASE CASE & 0.667 & 0.526 & 0.743 & 0.471. & 1.425 & 0.823 & 3.12 & 3.68 & 0.400 & 0.450 & 0.520 & 0.630 \\
\hline SCENARIO & 0.691 & 0.537 & 0.758 & $0.48:$ & 1.442 & 0.835 & 3.12 & 3.57 & 0.410 & 0.440 & 0.520 & 0.610 \\
\hline DIEEERENCE & 0.023 & 0.011 & 0.014 & 0.010 & 0.017 & 0.011 & 0.00 & -0.11 & 0.010 & -0.010 & 0.000 & -0.020 \\
\hline PERCENTAGE & 3.5 & 2.1 & 1.9 & 2.1 & 1.2 & 1.4 & 0.0 & -3.0 & 2.5 & -2.2 & 0.0 & -3.2 \\
\hline
\end{tabular}


Case 8: Time-of-Use Pricing $\$ 2$

Assumptions: All end uses and technologies are assumed to have an hourly price elasticity of . 5 .

Results: The annual load factor increases by $8 \%$, and the growth rate of peak demand decreases by $13 \%$. This effect is similar to. but about four times as large as that in Load Management Case 7. 
Table G-8

RESULTS OF LOAD MANAGEMENT ANALYSIS CASE 8

TIME OF USE PRICES, ELASTICITI $=: 5$

$$
\left(10^{12} \mathrm{Btu} / \mathrm{yr}\right)
$$

a. North Central Region

\begin{tabular}{|c|c|c|c|c|c|c|c|c|c|c|}
\hline \multirow[b]{2}{*}{$\begin{array}{l}\text { END USE } \\
R E S I D E N T I A L\end{array}$} & \multicolumn{7}{|c|}{ TECHNOLOGY } & \\
\hline & 1 & 2 & 3 & 4 & 5 & 6 & 7 & 3 & TOTAL & PERCENT \\
\hline $\begin{array}{l}\text { SPACE HEAT } \\
\text { WATER HEAT } \\
\text { AIR CONDITIONING }\end{array}$ & $\begin{array}{l}0.00 \\
0.00 \\
0.00\end{array}$ & $\begin{array}{r}107.28 \\
0.00 \\
0.00\end{array}$ & $\begin{array}{r}378.57 \\
137.51 \\
70.54\end{array}$ & $\begin{array}{r}0.00 \\
0.00 \\
21.87\end{array}$ & $\begin{array}{l}0.00 \\
0.00 \\
0.00\end{array}$ & $\begin{array}{l}0.00 \\
0.00 \\
0.00\end{array}$ & $\begin{array}{l}0.00 \\
0.00 \\
0.00\end{array}$ & $\begin{array}{l}0.00 \\
0.00 \\
0.00\end{array}$ & $\begin{array}{r}485.85 \\
137.51 \\
92.51\end{array}$ & $\begin{array}{r}16.40 \\
4.64 \\
3.12\end{array}$ \\
\hline $\begin{array}{l}\text { COOKING } \\
\text { OTHER } \\
\text { TOTAL }\end{array}$ & $\begin{array}{l}0.00 \\
0.00\end{array}$ & $\begin{array}{r}0.00 \\
\approx 62.78\end{array}$ & $\begin{array}{r}50.93 \\
0.00\end{array}$ & $\begin{array}{l}0.00 \\
0.00\end{array}$ & $\begin{array}{l}0.00 \\
0.00\end{array}$ & $\begin{array}{l}0.00 \\
0.00\end{array}$ & $\begin{array}{l}0.00 \\
0.00\end{array}$ & $\begin{array}{l}0.00 \\
0.00\end{array}$ & $\begin{array}{r}50.93 \\
362.78 \\
1129.59\end{array}$ & $\begin{array}{r}1.72 \\
12.25 \\
38.13\end{array}$ \\
\hline $\begin{array}{l}\text { COMMERCIAL } \\
\text { SPACE HEAT } \\
\text { AIR CONDITIONING } \\
\text { OTHER } \\
\text { TOTAL }\end{array}$ & $\begin{array}{l}0.00 \\
0.00 \\
0.00\end{array}$ & $\begin{array}{r}43.95 \\
0.00 \\
\text { E19.01 }\end{array}$ & $\begin{array}{r}24.12 \\
120.93 \\
0.00\end{array}$ & $\begin{array}{l}0.00 \\
0.00 \\
0.00\end{array}$ & $\begin{array}{l}0.00 \\
0.00 \\
0.00\end{array}$ & $\begin{array}{l}0.00 \\
0.00 \\
0.00\end{array}$ & $\begin{array}{l}0.00 \\
3.00 \\
0.00\end{array}$ & $\begin{array}{l}0.00 \\
0.00 \\
0.00\end{array}$ & $\begin{array}{r}68.07 \\
120.93 \\
619.01 \\
808.01\end{array}$ & $\begin{array}{r}2.30 \\
4.08 \\
20.90 \\
27.28\end{array}$ \\
\hline INDUSTRIAL & 0.00 & 1024.59 & 0.00 & 0.00 & 0.00 & 0.00 & 0.00 & 0.00 & 1024.59 & 34.59 \\
\hline TRAN SPORTATION & 0.00 & 0.00 & 0.00 & 0.00 & 0.00 & 0.00 & 0.00 & 0.00 & 0.00 & 0.00 \\
\hline TOTAL & & & & & & & & & 2962.20 & 100.00 \\
\hline
\end{tabular}

SUMNARY OUTPUTS - - NORTH CENTRAL $2000 \quad 12 / 18 / 79$ TIME OF USE PRICES, ELASTICITY $=.5$

\begin{tabular}{|c|c|c|c|c|c|c|c|c|c|c|c|c|}
\hline & WINTER & $\begin{array}{c}\text { COAD } B A C \\
\text { SUNMER }\end{array}$ & $\begin{array}{l}\text { TOPS } \\
\text { AUT / SPR }\end{array}$ & ANNUAL & $\begin{array}{l}\text { SEASONAL } \\
\text { SUM/WIN }\end{array}$ & $\begin{array}{c}\text { PEAK RATIOS } \\
\text { SPR/WIN }\end{array}$ & $\begin{array}{l}\text { GROWTH } \\
\text { ENERGY }\end{array}$ & $\begin{array}{l}\text { RATEE } \\
P E A K\end{array}$ & $\underset{15}{\text { CUMULATIVE }}$ & $\underset{30}{\angle O A D}$ & $\begin{array}{c}B Y \text { CAPACITY } \\
50\end{array}$ & $\begin{array}{c}\text { Y EACTOR } \\
70\end{array}$ \\
\hline BASE CASE & 0.652 & 0.516 & 0.788 & 0.546 & 1.041 & 0.688 & 2.84 & 3.13 & 0.300 & 0.370 & 0.430 & 0.540 \\
\hline SCENARIO & 0.700 & 0.559 & 0.839 & 0.591 & 1.032 & 0.694 & 2.84 & 2.72 & 0.270 & 0.330. & 0.380 & 0.480 \\
\hline DIFFERENCE & 0.049 & 0.043 & 0.051 & 0.04 .5 & -0.009 & 0.006 & 0.00 & -0.41 & -0.030 & 0.040 & -0.050 & -0.060 \\
\hline PERCENTAGE & 7.4 & 8.3 & 6.5 & 8.3 & -0.9 & 0.9 & $0 . c$ & -13.0 & -10.0 & -10.8 & -11.6 & -11.1 \\
\hline
\end{tabular}


Table G-8, Continued

b. South Central Region

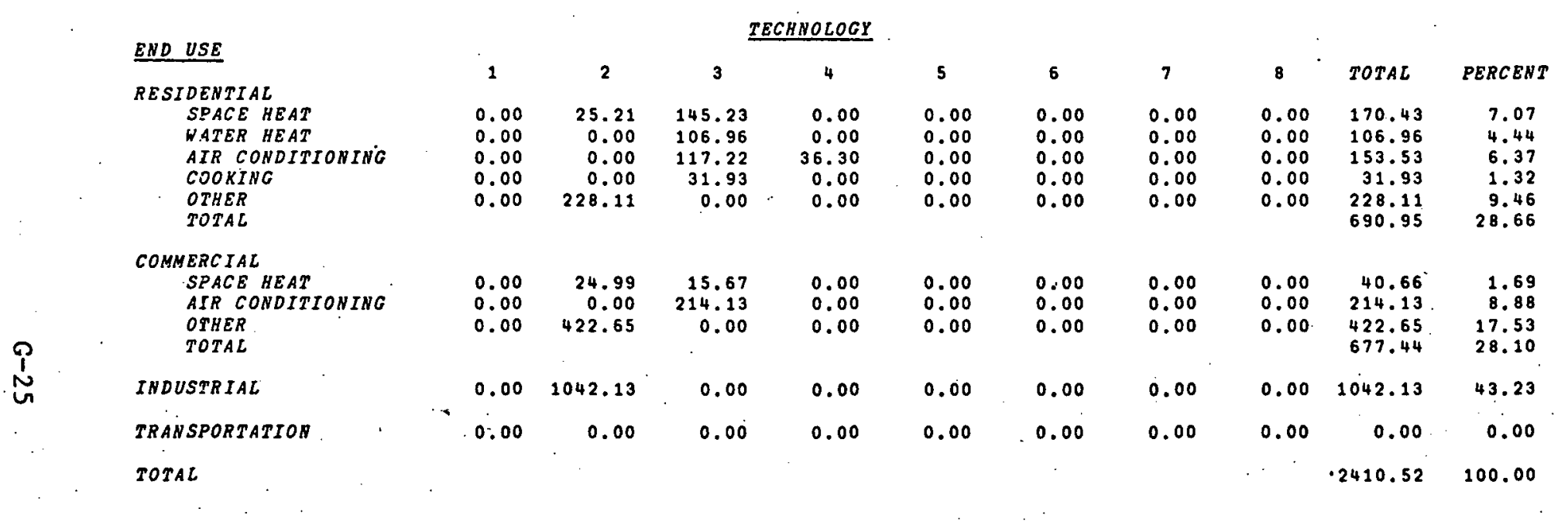

SUMMARY OUTPUTS - - SOUTH CENTRAL $2000 \quad 12 / 18 / 79$ TIHE OF USE PRICES, ELASTICITY $=.5$

\begin{tabular}{lccccc} 
& \multicolumn{5}{c}{ LOAD FACTORS } \\
BASE CASE & WINTER SUMMER & AUT/SPR ANNUAL \\
SCENARIO & 0.667 & 0.526 & 0.743 & 0.471 \\
DIPFERENCE & 0.711 & 0.572 & 0.779 & 0.512 \\
PERCENTAGE & 0.044 & 0.046 & 0.036 & 0.041 \\
& 6.5 & 8.7 & 4.8 & 8.7
\end{tabular}
SEASONAE PEAK RATIOS
SUM/WIN SPR/WIN

1.425.

1.395

$-0.029$

$-2.1$
GROWTH RATES BNERGY PEAK

3.123 .68

$3.12 \quad 3.25$

$0.00 \quad-0.43$

$0.0 \quad-11.7$ $\begin{array}{cccc}\text { CUNULATIVE } & \text { LOAD BY CAPACITY FACTOR } \\ 15 & 30 & 50 & 70\end{array}$

$\begin{array}{rrrr}0.400 & 0.450 & 0.520 & 0.630 \\ 0.380 & 0.410 & 0.490 & 0.570 \\ -0.020 & -0.040 & -0.030 & -0.060 \\ -5.0 & -8.9 & -5.8 & -9.5\end{array}$


Case 9: Time-of-Use Pricing \#3

Assumptions: A1l end uses and technologies are assumed to have an energy elasticity of .5 and an hourly price elasticity of .1 .

Results: $\quad$ The increase in annual load factor is $8 \%$, the same as Case 8 . However, in this case both energy growth and peak load growth are reduced. 
Table $G \div 9$

RESULTS OF LOAD MANAGEMENT ANALYSIS CASE 9

TIME OF USE PRICES, PRICE ELASTICITY $=.5$, ELASTICITY $=.1$

$\left(10^{12} \mathrm{Btu} / \mathrm{yr}\right)$

a. North Central Region

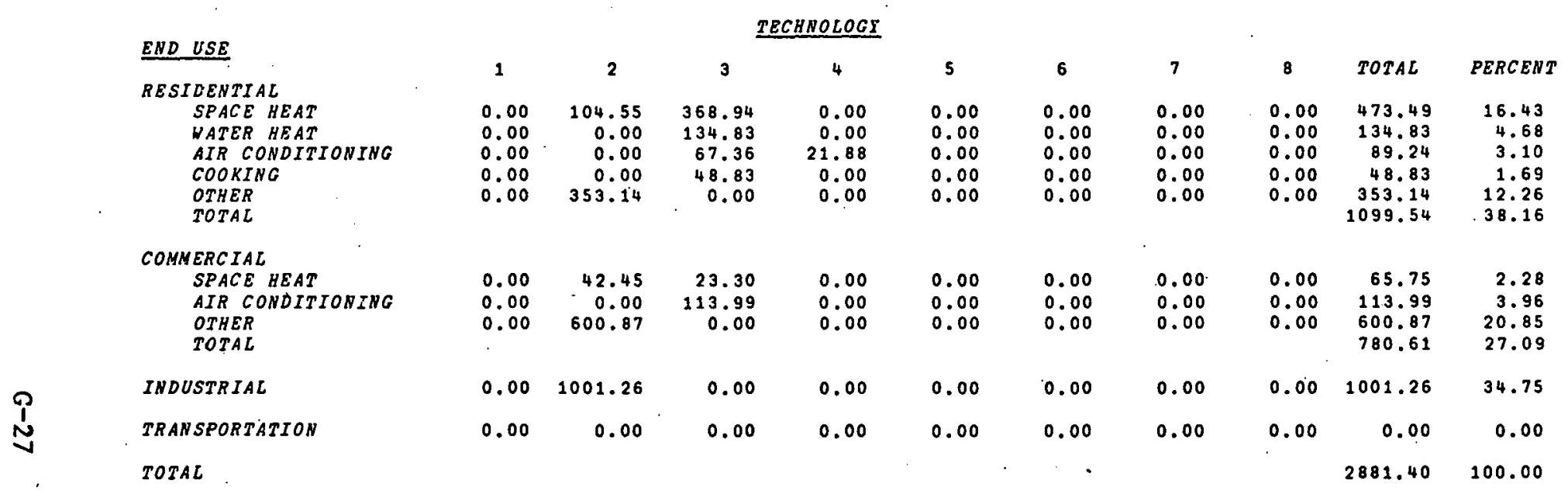

SUMMARI OUTPUTS -- NORTH CENTRAL $200012 / 18 / 79$

TIME OP USE PRICES. PRICE ELASTICITY $=.5$. ELASTICITY $=.1$

\begin{tabular}{lcccc} 
& \multicolumn{5}{c}{ LOAD FACTORS } \\
& WINTER & \multicolumn{1}{c}{ SUMMER } & AUT/SPR & ANNUAL \\
BASE CASE & 0.652 & 0.516 & 0.788 & 0.546 \\
SCENARIO & 0.696 & 0.562 & 0.831 & 0.592 \\
DIFFERENCE & 0.044 & 0.046 & 0.043 & 0.046 \\
PERCENTAGE & 6.8 & 8.8 & 5.4 & 8.5
\end{tabular}

\begin{tabular}{|c|c|c|c|}
\hline $\begin{array}{l}\text { SEASONAL } \\
\text { SUM/WIN }\end{array}$ & $\begin{array}{l}E A R \text { RATIOS } \\
\text { SPR /WIN }\end{array}$ & $\begin{array}{l}\text { GROWTA } \\
\text { ENERGY }\end{array}$ & $\begin{array}{r}R A T E S \\
\text { PEAK }\end{array}$ \\
\hline $1.04 \mathrm{i}$ & 0.688 & 2.84 & 3.13 \\
\hline 1.046 & 0.722 & 2.70 & 2.56 \\
\hline 0.005 & 0.034 & -0.14 & 7 \\
\hline 0.5 & 4.9 & -5.0 & -18.2 \\
\hline
\end{tabular}

\begin{tabular}{|c|c|c|c|}
\hline $\begin{array}{l}\text { CUMULATIVB } \\
15\end{array}$ & $\begin{array}{c}B \quad \angle O A D \\
30\end{array}$ & $\begin{array}{c}B Y \text { CAPACITY } \\
50\end{array}$ & $\begin{array}{c}\text { PACTOR } \\
70\end{array}$ \\
\hline 0.300 & 0.370 & 0.430 & 0.540 \\
\hline 0.260 & 0.320 & 0.380 & 0.480 \\
\hline-0.040 & -0.050 & -0.050 & -0.060 \\
\hline-13.3 & -13.5 & -11.6 & -11.1 \\
\hline
\end{tabular}


Table G-9, Continued

b. South Central Region

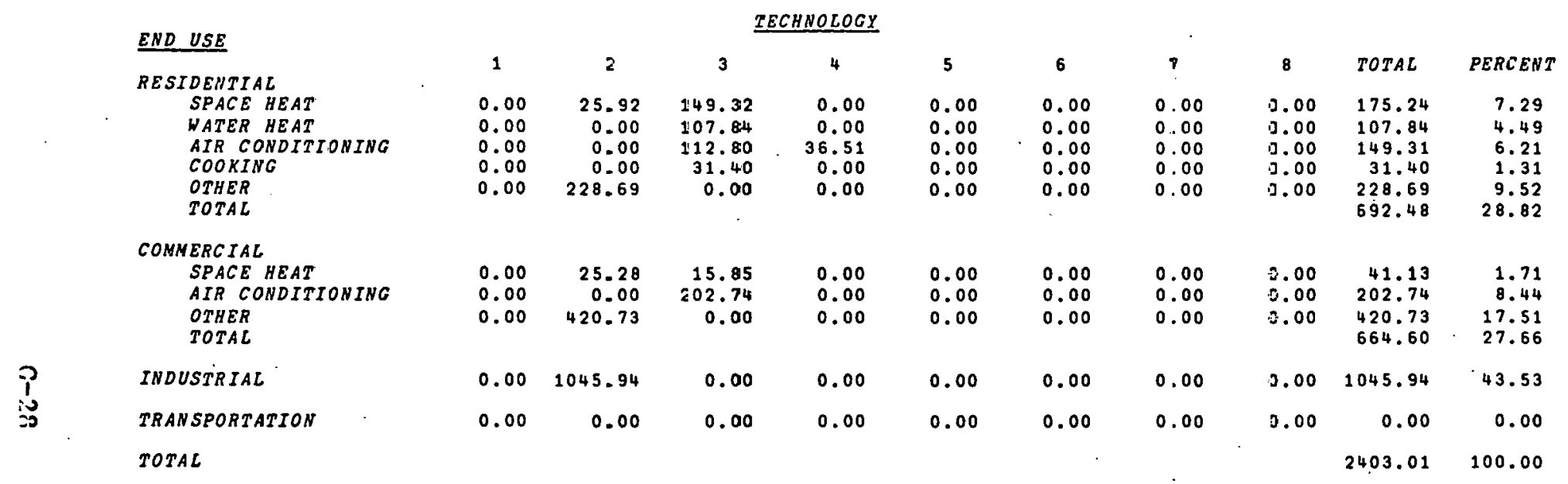

SUMMARY OUTPUTS -- SOUTH CENTRAL 2000 12/18/79

TIME OF USE PKICES, PRICE ELASTICITY $=.5$. BLASTICITY $=.1$

\begin{tabular}{|c|c|c|c|c|c|c|c|c|c|c|c|c|}
\hline & WINTER & $\begin{array}{c}\text { LOAD RAC } \\
\text { SUMNER }\end{array}$ & $\begin{array}{l}\text { TORS } \\
A U T / S P R\end{array}$ & ANKUAL & $\begin{array}{l}\text { SEASONAL } \\
\text { SUM/WIN }\end{array}$ & $\begin{array}{l}\text { EAK RATIOS } \\
S P R / W I N\end{array}$ & $\begin{array}{l}\text { GROPTH } \\
\text { ENEPGY }\end{array}$ & $\begin{array}{l}\text { RATES } \\
\text { PEAK }\end{array}$ & $\begin{array}{c}\text { COMULATIVE } \\
15\end{array}$ & $\begin{array}{c}E O A D \\
30\end{array}$ & $\begin{array}{c}B Y \text { CAPACITY } \\
50\end{array}$ & $\begin{array}{c}\text { PACTOR } \\
70\end{array}$ \\
\hline$B A S E$ CASE & 0.667 & 0.526 & 0.743 & 0.471 & 1.425 & 0.823 & 3.12 & 3.68 & 0.400 & 0.450 & 0.520 & 0.630 \\
\hline SCENARIO & 0.717 & 0.566 & $0.76 \mathrm{~B}$ & 0.522 & 1.365 & 0.864 & 3.10 & 3.13 & $c .360$ & 0.390 & 0.470 & 0.570 \\
\hline DIFEERENCE & 0.050 & 0.040 & 0.025 & 0.051 & -0.059 & 0.041 & -0.02 & -0.55 & 0.040 & -0.060 & -0.050 & -0.060 \\
\hline PERCENTAGE & 7.5 & 7.6 & 3.3 & 16.8 & -4.2 & 5.0 & -0.5 & -14.9 & -10.0 & -13.3 & -9.6 & -9.5 \\
\hline
\end{tabular}


Case 10: Time-of-Use Pricing $\$ 4$

Assumptions: All end uses and technologies are assumed to have an energy elasticity of .5. Hourly elasticities are assumed to be as follows :

$\begin{array}{ll}\text { Residential } & .1 \\ \text { Commercial } & .2 \\ \text { Industrial } & .3\end{array}$

Results: The annual load factor increases by about 10\% (6 percentage points). This is about two-thirds of the increase of intensive load management activities of Load Management Case 5. 
Table G-10

\section{RESULTS OF LOAD MANAGEMENT ANALYSIS CASE 10}

TIME OF USE PRICES

PRICE ELASTICITY $=.5 ;$ ELASTICITY: RES $=.1$, COMM $=.2$, IND $=.3$

$$
\left(10^{12} \mathrm{Btu} / \mathrm{yr}\right)
$$

\section{a. North Central Region}

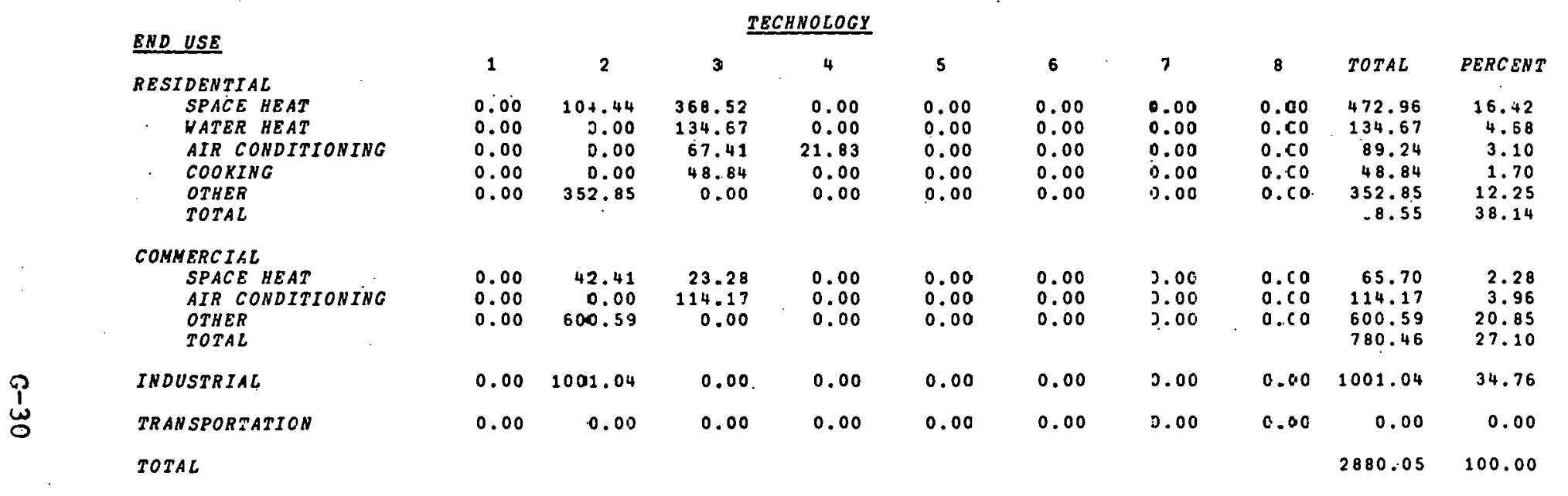

SUMMAKY OUTPUTS -- NORTH CENTRAL 2000 12/31/79

TOU PЋICES, DRICE ELAS $=.5$, ELAS: RES $=.1$ COMM $=.2$ IND=.3

\begin{tabular}{|c|c|c|c|c|c|c|c|c|c|c|c|c|}
\hline & WINTER & $\begin{array}{c}\angle O A D F A C \\
\text { SUMMER }\end{array}$ & $\begin{array}{l}\text { TORE } \\
\text { AUP/SPR }\end{array}$ & ANNUA: & $\begin{array}{l}\text { SEASONAL } \\
\text { SUN/WIN }\end{array}$ & $\begin{array}{c}\text { EAK PATIOS } \\
\text { SPR /WIN }\end{array}$ & $\begin{array}{l}\text { GROWTH } \\
\text { ENERGY }\end{array}$ & $\begin{array}{r}\text { RATES } \\
\text { PEAK }\end{array}$ & $\begin{array}{c}\text { CUMULATIVE } \\
15\end{array}$ & 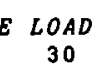 & $\begin{array}{c}B Y \text { CAPACITY } \\
50\end{array}$ & $\begin{array}{c}\text { FACTOR } \\
70\end{array}$ \\
\hline BASE CASE & 0.652 & 0.516 & 0.288 & 0.546 & .1 .041 & 0.688 & 2.84 & 3.13 & 0.300 & 0.370 & 0.430 & 0.540 \\
\hline SCENARIO & 0.701 & 0.572 & 0.837 & 0.601 & 1.039 & 0.723 & 2.69 & 2.48 & 0.260 & 0.310 & 0.370 & 0.460 \\
\hline DIFFERENGE & 0.049 & 0.055 & 0.049 & 0.056 & -0.002 & 0.035 & -0.14 & -0.64 & -0.040 & -0.060 & -0.060 & 0.080 \\
\hline PERCENTAGE & 7.6 & 10.7 & 6.2 & 10.2 & -0.2 & 5.2 & -5.1 & -20.6 & -13.3 & -16.2 & -14.0 & -14.8 \\
\hline
\end{tabular}


Table G-10, Continued

b. South Central Region

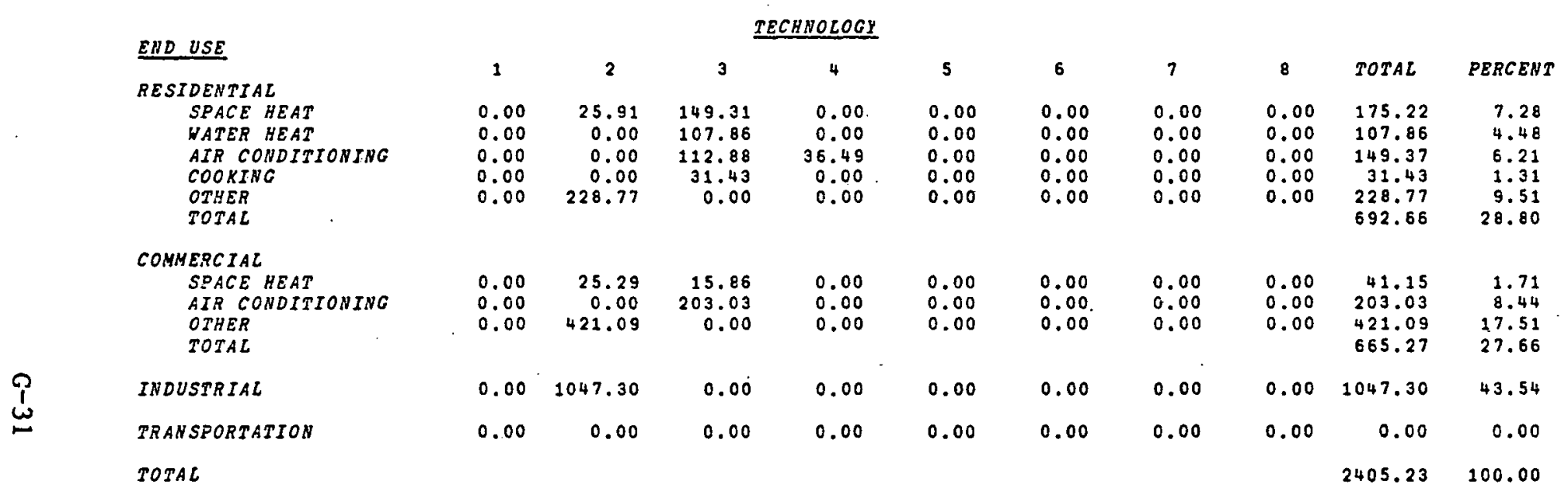

SUMMARY OUTPUTS -- SOUTH CENTPAL $20001 / 8 / 80$

TOU PRICES. PRICE ELAS $=.5$, ELAS: RES $=.1$ COMM $=.2$ IND $=.3$

\begin{tabular}{|c|c|c|c|c|c|c|c|c|c|c|c|c|}
\hline . & WINTER & $\begin{array}{c}\text { LOAD FAC } \\
\text { SUMMER }\end{array}$ & $\begin{array}{l}\text { TORS } \\
\text { AUT / SPR }\end{array}$ & ANNUAL & $\begin{array}{l}\text { SEASONAL. } \\
\text { SUM /WIN }\end{array}$ & $\begin{array}{c}P E A K \text { RATIOS } \\
\text { SPR/WIN }\end{array}$ & $\begin{array}{l}\text { GROWTH } \\
\text { ENERGY }\end{array}$ & $\begin{array}{r}\text { RATES } \\
\text { PEAK }\end{array}$ & $\begin{array}{c}\text { CUMULATIV } \\
15\end{array}$ & $\begin{array}{c}E O A D \\
30\end{array}$ & $\begin{array}{c}B Y \text { CAPACITY } \\
50\end{array}$ & $\begin{array}{c}\text { FACTOR } \\
70\end{array}$ \\
\hline BASE CASE & 0.667 & 0.526 & 0.743 & 0.471 & 1.425 & 0.823 & 3.1 .2 & 3.68 & 0.400 & 0.450 & 0.520 & 0.630 \\
\hline SCENARIO & 0.723 & 0.576 & 0.778 & 0.532 & 1.351 & 0.863 & 3.11 & 3.04 & 0.360 & 0.380 & 0.460 & $0.560^{\circ}$ \\
\hline DIFEERENCE & 0.055 & 0.050 & 0.034 & 0.061 & -0.073 & 0.040 & -0.01 & -0.64 & -0.040 & -0.070 & 0.060 & -0.070 \\
\hline PERCENTAGE & 8.3 & 9.5 & 4.6 & 12.9 & -5.2 & 4.8 & -0.4 & -17.4 & -10.0 & -15.6 & -11.5 & -11.1 \\
\hline
\end{tabular}


Case 11: Solar Systems with Energy Storage

Assumptions: The electric backup of the solar heating system described in Sensitivity Case 18 has an energy storage capability.

Results: The overall impact of this case is the same as in Sensitivity Case 18. In both cases, the annual load factor drops by $3.5 \%$ compared to the base case. In this case the winter load factor is increased by about $10 \%$, but the main effect of this is to make the system strongly summer peaking rather than to increase the annual load factor. 
Table G-11

RESULTS OF LOAD MANAGEMENT ANALYSIS CASE 11

SOLAR WITH ENERGY STORAGE

$\left(10^{12} \mathrm{Btu} / \mathrm{yr}\right)$

a. North Central Region

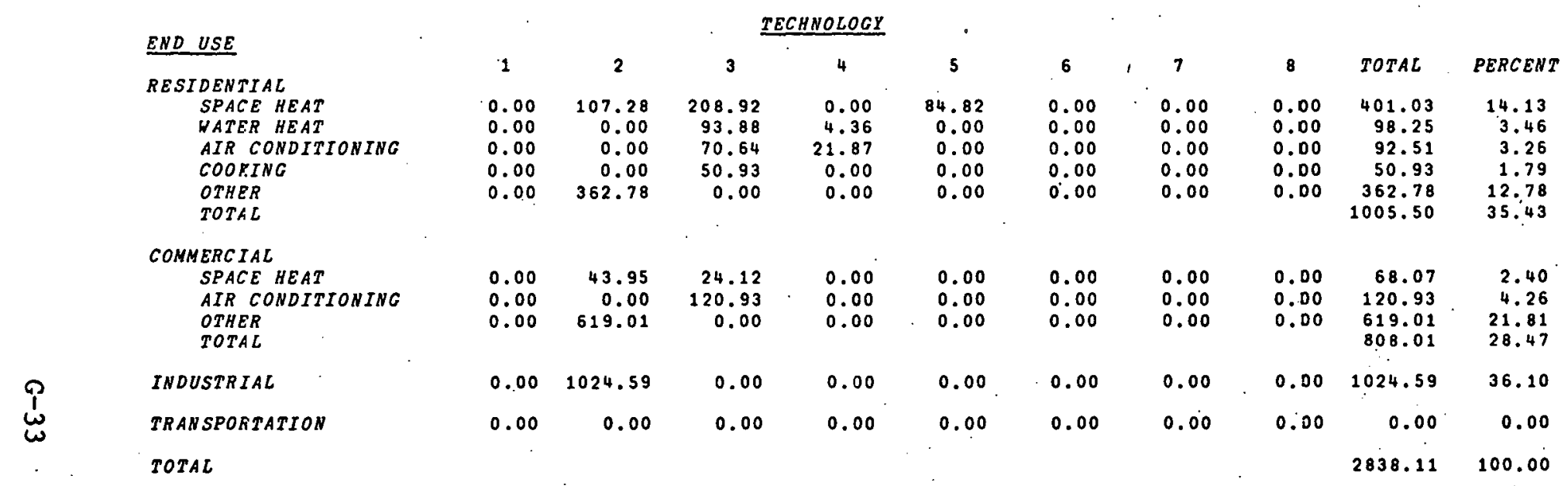

SUMMARY OUTPUTS -- NORTH CENTRAL 2000 12/31/79 SOLAR WITH. ENERGY STORAGE

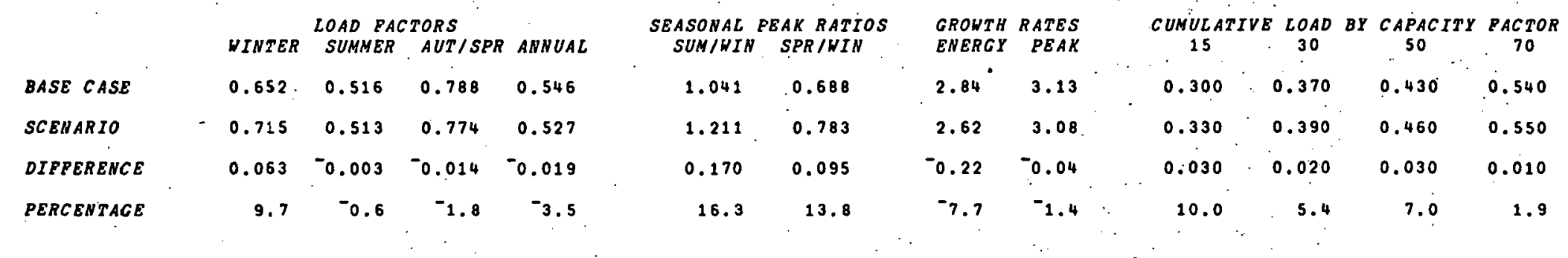


Table G-11, Continued

\section{b. South Central Region}

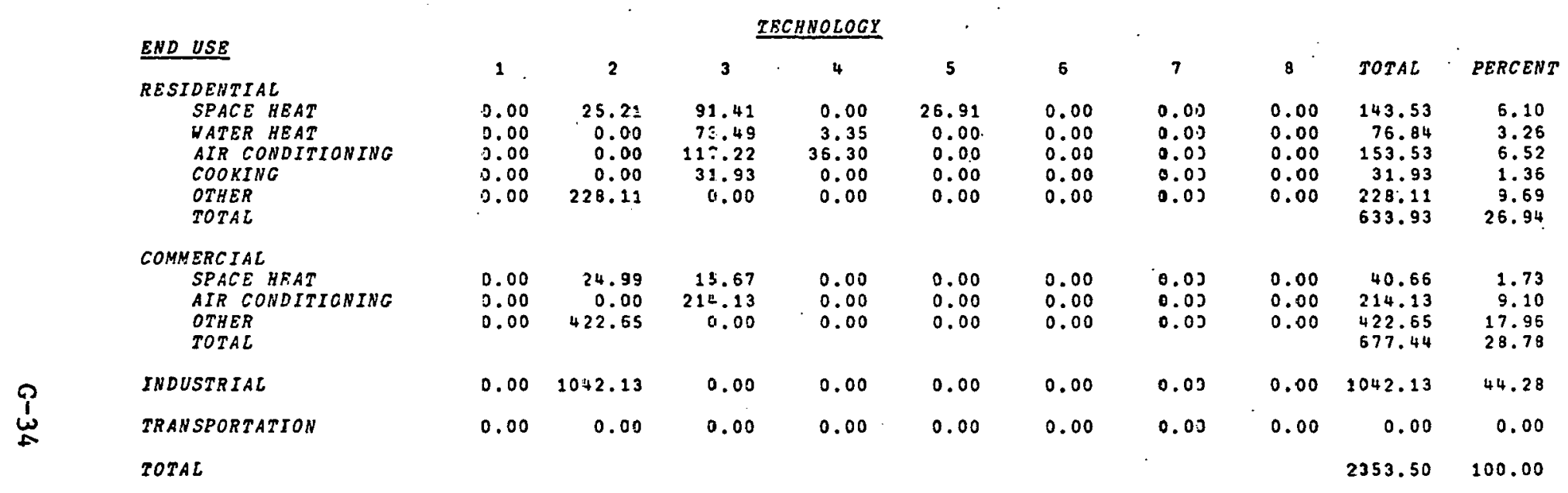

SUNMARY OUTPUTS -- SOUTA CENTRAL 2000 1/8/80 SOLAR UITE ENERGY STORAGE

\begin{tabular}{|c|c|c|c|c|}
\hline & WIVTER & $\begin{array}{c}\text { LOAD EAC } \\
\text { SUMMER }\end{array}$ & $\begin{array}{l}\text { TORS } \\
A U T / S P R\end{array}$ & ANDUAL \\
\hline BASE CASE & 0.667 & 0.526 & 0.743 & 0.471 \\
\hline SCENARIO & 0.717 & 0.524 & 0.741 & 0.463 \\
\hline DIPPERENCE & 0.050 & -0.003 & -0.003 & -0.00 is \\
\hline PERCENTAGE & 7.4 & -0.5 & -0.4 & -1.6 \\
\hline
\end{tabular}

\begin{tabular}{cccc} 
SEASONAL & PEAK RATIOS & \multicolumn{2}{c}{ GROHTI } \\
SUMIWIN & SPR/WIN & BHERGY & PEAK \\
1.425 & 0.823 & 3.12 & 3.68 \\
1.588 & 0.907 & 3.00 & 3.64 \\
0.164 & 0.084 & -0.12 & -0.04 \\
11.5 & 10.2 & -4.0 & -1.0
\end{tabular}

CUNULATIVE LOAD BY CAPACITY PACTOR

$15030 \quad 50 \quad 70$

$\begin{array}{llll}0.400 & 0.450 & 0.520 & 0.630\end{array}$

$\begin{array}{llll}0.420 & 0.460 & 0.530 & 0.640\end{array}$

$0.020 \quad 0.010 \quad 0.010 \quad 0.010$

$\begin{array}{llll}5.0 & 2.2 & 1.9 & 1.6\end{array}$ 
Case 12: Interruptible Service on $25 \%$ of Industrial Load

Assumptions: Up to $25 \%$ of the industrial load can be Interrupted up to four hours on either peak summer or peak winter days.

Results: The summer and annual load factors are both increased by about $6.5 \%$. Summer and winter become perfectly balanced, since the summer and winter peaks can be chopped at exactly the same level. The effect is about the same as performing load management on $25 \%$ of the industrial load (Load Management Case 4). 
Table G-12

RESULTS OF LOAD MANAGEMENT ANALYSIS CASE 12

INTERRUPTIELE LOAD - 25 PERCENT OF INDUSTRIAL DEMAND

$$
\text { (10 } 12 \mathrm{Btu} / \mathrm{yr})
$$

a. North Central Region

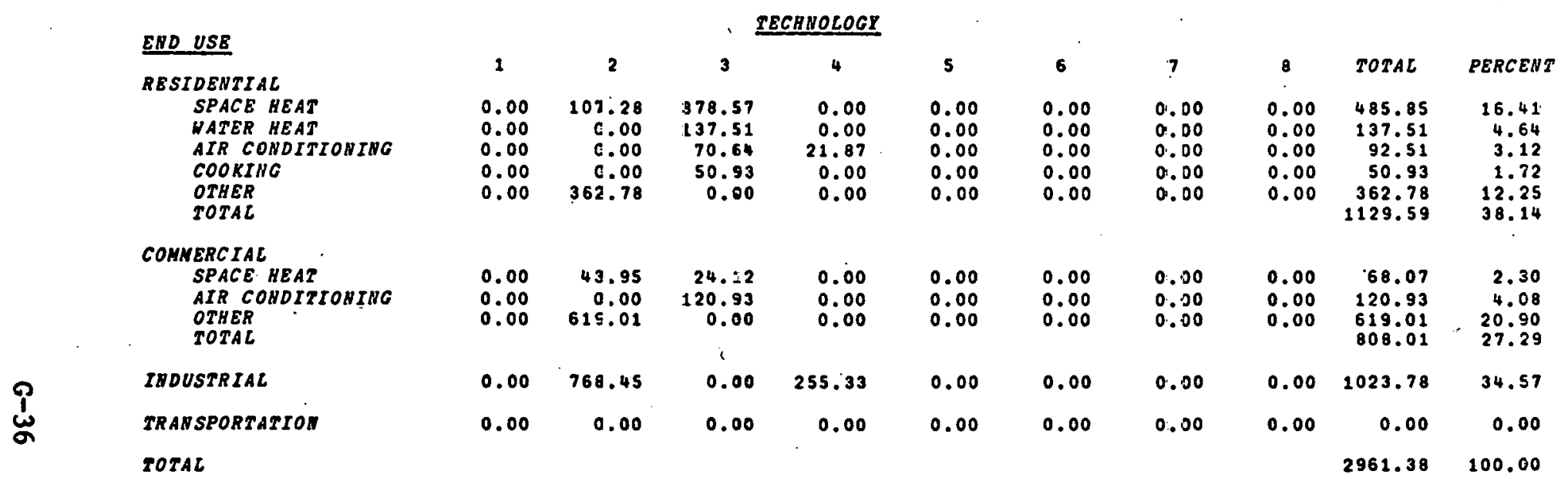

SUNAARY OUTPUTS -- DORTH CENTRAL 2000 12/18/79

IATZRR LPTIBLE LOAD - 25 PERCENT OF INDUSTRIAL DENAHO

\begin{tabular}{|c|c|c|c|c|c|c|c|c|c|c|c|c|}
\hline & WIMTER & $\begin{array}{c}\text { CDAD } P A C \\
\text { SUNKER }\end{array}$ & $\begin{array}{l}\text { TORS } \\
\text { BUT/SPR }\end{array}$ & ANDUAL & $\begin{array}{l}\text { SEASOHAL } \\
\text { SUM/WIN }\end{array}$ & $\begin{array}{c}\text { PEAR RATIOS } \\
\text { SPR/WIN }\end{array}$ & $\begin{array}{l}\text { GROYTH } \\
\text { ENEZGY }\end{array}$ & $\begin{array}{r}\text { RATES } \\
\text { PEAK }\end{array}$ & $\underset{15}{\text { CUMULATIVE }}$ & $B$ COAD & $\begin{array}{c}B Y C A P A C I T Y \\
50\end{array}$ & $\begin{array}{c}\text { PACTOR } \\
70\end{array}$ \\
\hline BASB CASB & 0.652 & 0.516 & 0.788 & 0.546 & 1.041 & 0.688 & 2.84 & 3.13 & 0.300 & 0.370 & 0.430 & 0.540 \\
\hline SCENARIO & 0.667 & 0.550 & 0.787 & 0.581 & 1.000 & 0.704 & 2.84 & 2.80 & 0.260 & 0.330 & 0.390 & 0.510 \\
\hline DIREEREHCE & 0.015 & 0.034 & -0.001 & 0.035 & -0.041 & 0.016 & -0.00 & -0.33 & -0.040 & -0.040 & -0.040 & -0.030 \\
\hline PERCEUTAGE & 2.3 & 6.6 & -0.1 & 6.5 & -3.9 & 2.3 & -0.0 & -10.4 & -13.3 & -10.8 & -9.3 & -5.6 \\
\hline
\end{tabular}


Table G-12, Continued

b. South Central Region

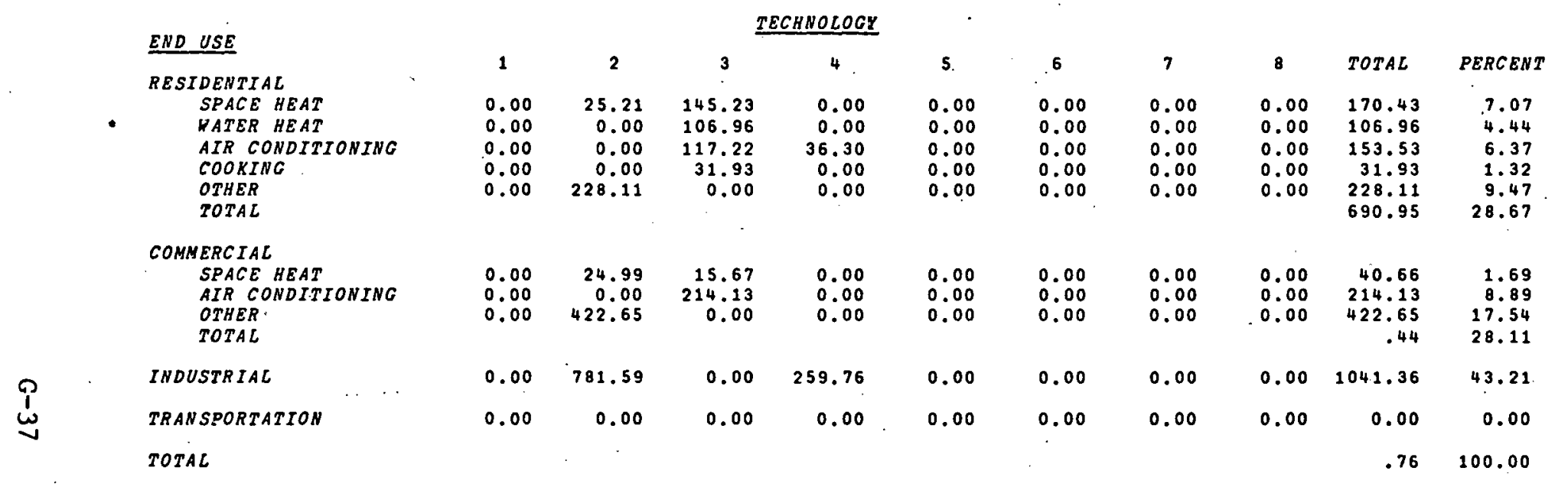

SUMMARY OUTPUTS -- SOUTH CENTRAL 2000 1/8/80

INTERR UPTIBLE LOAD - 25 PERCENT OF INDUSTRIAL DEMAND

\begin{tabular}{|c|c|c|c|c|c|c|c|c|c|c|c|c|}
\hline & UINTER & $\begin{array}{l}\text { LOAD FAC } \\
\text { SUMMER }\end{array}$ & $\begin{array}{l}\text { TORS } \\
\text { AUT / SPR }\end{array}$ & ANNUAL & $\begin{array}{l}\text { SEASONAL } \\
\text { SUM/WIN }\end{array}$ & $\begin{array}{c}\text { EAK RATIOS } \\
\text { SPR/WIN }\end{array}$ & $\begin{array}{l}\text { GROWTH } \\
\text { ENERGY }\end{array}$ & $\begin{array}{r}\text { RATES } \\
\text { PEAK }\end{array}$ & $\underset{15}{\operatorname{CUMULATIV}}$ & $\begin{array}{c}E C O A D \\
30\end{array}$ & $\begin{array}{c}\text { BY CAPACITY } \\
50\end{array}$ & $\begin{array}{c}\text { PACTOR } \\
70\end{array}$ \\
\hline$B A S E$ CASE & 0.667 & 0.526 & 0.743 & 0.471 & 1.425 & 0.823 & 3.12 & 3.68 & 0.400 & 0.450 & 0.520 & 0.630 \\
\hline SCENARIO & 0.667 & 0.563 & 0.744 & 0.504 & 1.330 & 0.823 & 3.12 & 3.32 & 0.360 & 0.410 & 0.480 & 0.610 \\
\hline DIPFERENCE & -0.000 & 0.037 & 0.000 & 0.033 & -0.094 & 0.000 & -0.00 & -0.35 & -0.040 & -0.040 & -0.040 & -0.020 \\
\hline PERCENTAGE & -0.0 & 7.0 & 0.0 & 7.1 & -6.6 & 0.0 & -0.1 & -9.6 & -10.0 & -8.9 & -7.7 & -3.2 \\
\hline
\end{tabular}




\section{Appendix $\mathrm{H}$}

\section{SIMPLIFIED EXAMPLE ILLUSTRATING HOW THE AVAILABILITY OF VERY LOW COST (FREE) STORAGE WOULD DECREASE THE FRACTION OF COAL (BASELOAD) CAPACITY IN THE OPTIMAL GENERATION MIX}

Figure $\mathrm{H}$ is used to illustrate how the availability of a very low cost storage technology with an energy efficiency of, say, 0.75 would decrease the amount of baselnad (coal) generatiun capacity in the optimal mix. The illustration is included here not because it is likely to happen, or even because it is realistic, but rather to show that although it is counterintuitive the above situation is logically consistent.

The diagrams on the left show conceptually how the load duration curve and "screening" curves are used to determine the amounts of oil-fired combustion turbines and coal capacity that minimize the total cost of power in the absence of storage. The crossover point of the two cost curves in the bottom graph indicates that for load factors greater than A coal is the least expensive way to supply the energy. The hypothetical load duration curve indicates that 80 percent of the demand has a load factor greater than $A$ and 80 percent of the generation capacity should therefore be coal.

The diagrams on the right show that if a storage device were available with an efficiency of 0.75 then 35 percent of the demand could most economically be provided by storage and the optimal fraction of coal capacity is 0.65 . Since this is less than the result of the no-storage case (0.8), the avallability of free storage capacity thus decreases the fraction of coal in the optimal generation. 


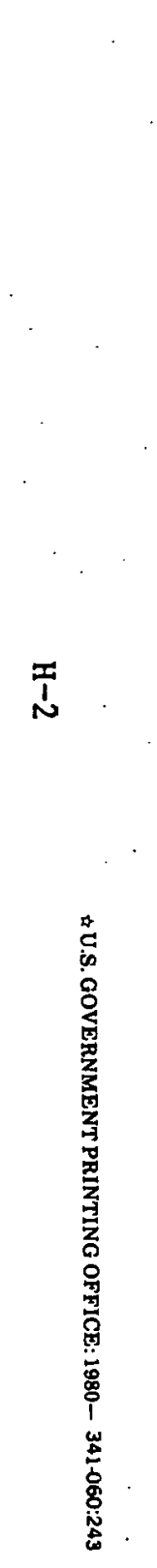

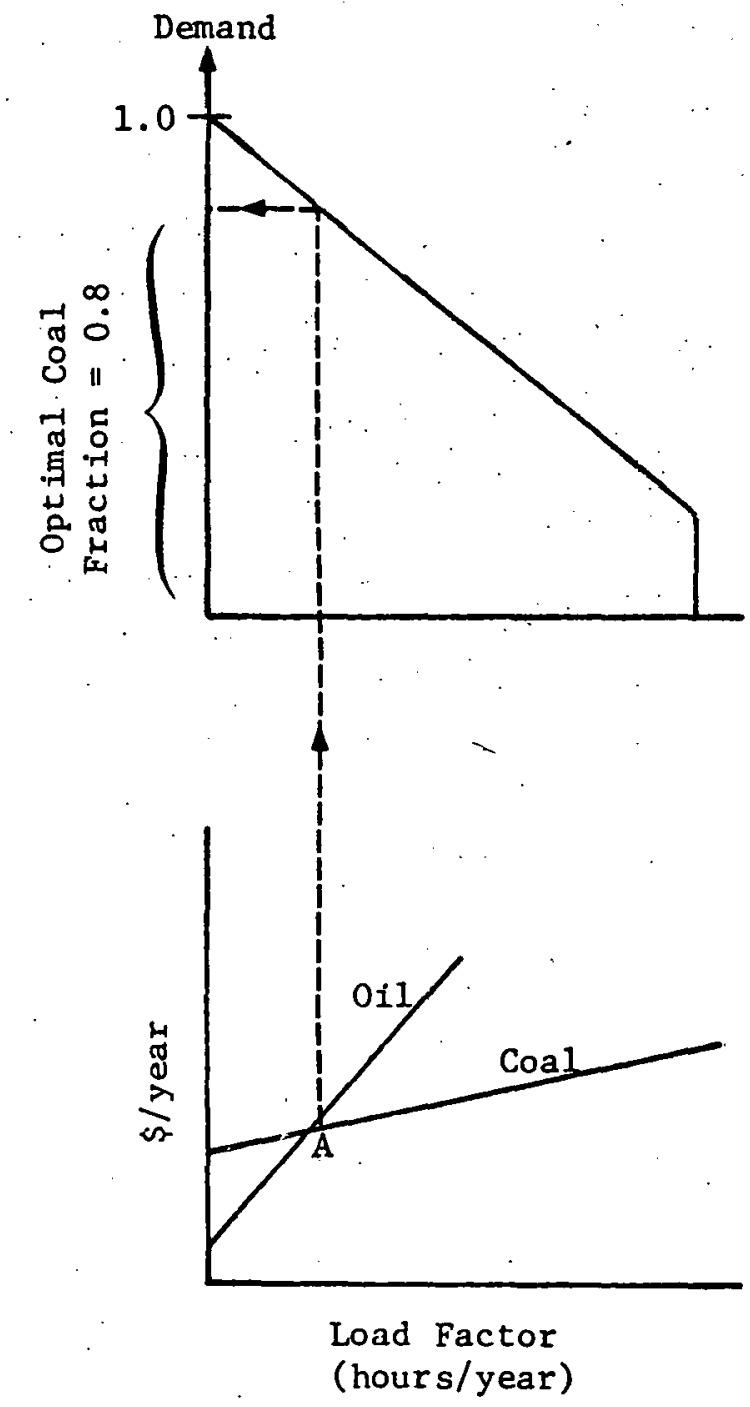

NO STORAGE AVAILABLE
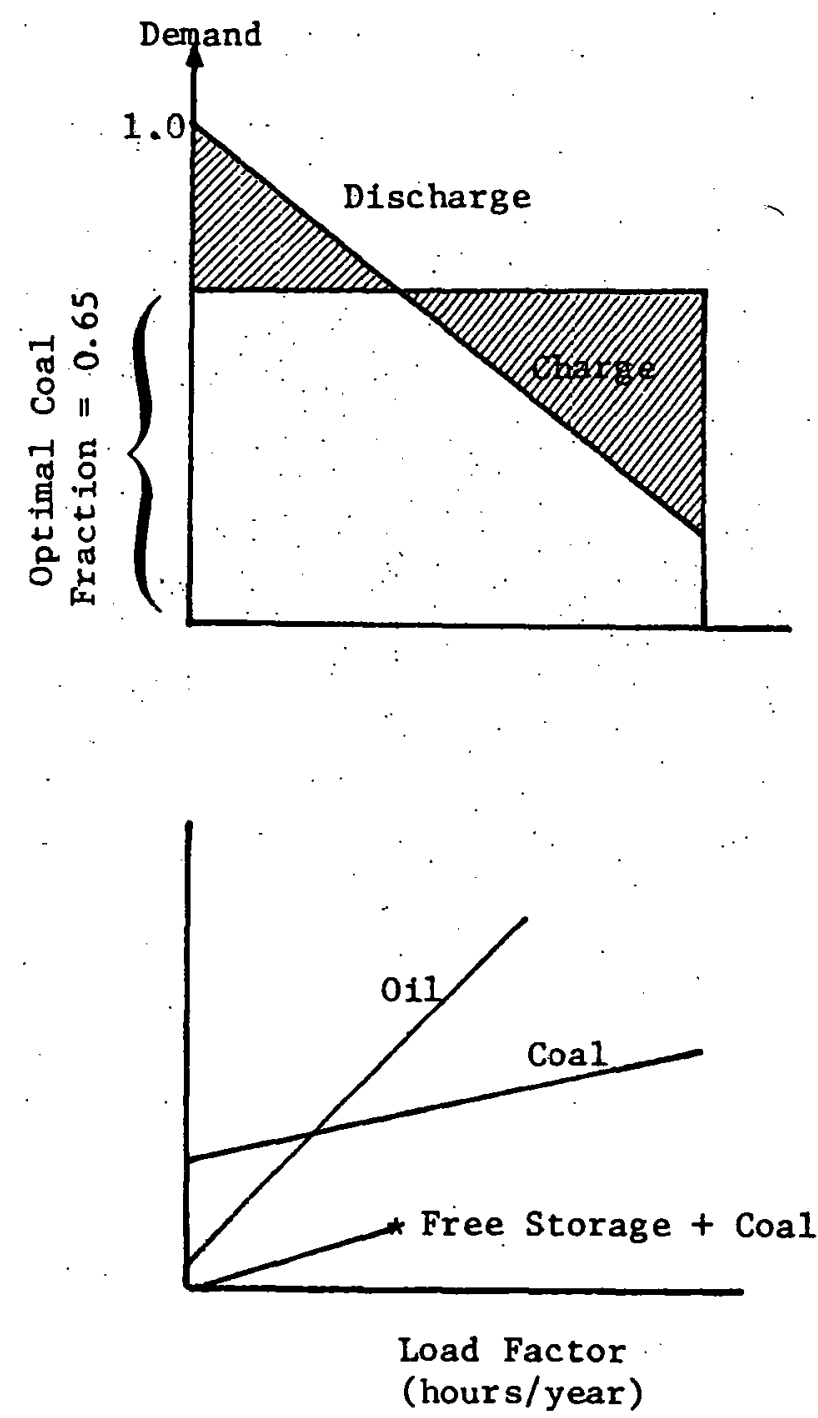

FREE STORAGE AVAILABLE

Figure H. Optimal Coal Capacity W1th and Without Very Low Cost Storage 